Universidade de São Paulo

Faculdade de Filosofia, Letras e Ciências Humanas

Programa de Pós-Graduação em História Econômica

\title{
Corporação dos enteados: \\ tensão, contestação e negociação política na Conjuração Baiana de 1798
}

Patrícia Valim

Orientadora: Prof ${ }^{\mathrm{a}}$. Dr ${ }^{\mathrm{a}}$. Vera Lúcia Amaral Ferlini

Tese apresentada ao Programa de PósGraduação em História Econômica do Departamento de História da Faculdade de Filosofia, Letras e Ciências Humanas da Universidade de São Paulo, para a obtenção do título de Doutora em História.

VERSÃO CORRIGIDA

São Paulo

2012 
Autorizo a reprodução e divulgação total ou parcial desta tese, por meio convencional ou eletrônico, para fins de estudo e pesquisa, desde que citada a fonte.

Aprovada em:

De acordo,

Prof. ${ }^{\text {a }}$ Dr ${ }^{\text {a }}$ Vera Lúcia Amaral Ferlini 
Para Ana, Bento e Maria, os meus sonhos mais lindos ... 


\section{Agradecimentos}

A escrita dos agradecimentos de uma tese de doutorado talvez seja o único momento em que o pesquisador tem a oportunidade de sobrepor as suas cores no lugar dos conceitos. É um momento carregado de alguma emoção, sobretudo quando o olhar em perspectiva se depara com muito carinho, companheirismo e amor de pessoas queridas, fundamentais para que essa etapa fosse concluída. No meu caso, as cores ficam ainda mais intensas porque durante a pesquisa de doutorado eu tive um filho, Bento, meu menino mais lindo do mundo, que me deu a chance de sair do confortável campo semântico de revoltas, motins e sedições para fazer a minha revolução pessoal.

Por isso, quero agradecer imensamente às minhas lindas filhas, Ana e Maria, que foram companheiras incansáveis durante todo o processo de doutorado e são responsáveis por alegrar a nossa excêntrica família. Vocês e Bentinho são os meus sonhos mais lindos. Em marte, eu não sei, mas aqui na terra não existe amor maior do que eu sinto por vocês. Agradeço aos meus queridos pais, Cida e Gilberto, que estão sempre por perto ajudando muito com meus filhos. Eu amo vocês. Ao Raphael Debei, por tratar com respeito e amor a minha Aninha, e nos alegrar com a sua presença!

Agradeço imensamente à minha querida orientadora, Prof ${ }^{a}$. Dr ${ }^{a}$. Vera Lúcia Amaral Ferlini, pelo privilégio de ser sua orientanda, por acolher meus argumentos sobre 1798 e pelo apoio incondicional e irrestrito ao longo desses últimos anos. Contar com a sua amizade nos momentos mais aflitivos foi fundamental para que essa etapa fosse concluída. Obrigada por tudo, mesmo.

Agradeço à Cátedra Jaime Cortesão pela dotação da bolsa de pesquisa em Portugal e por todas as oportunidades que me foram franqueadas durante esses anos de pesquisa. Agradeço muito à Patrícia Machado que trata a todos da Cátedra Jaime Cortesão com a maior gentileza e carinho. Agradeço ao Conselho Nacional de Desenvolvimento Científico e Tecnológico (CNPq) pelo suporte financeiro concedido nos quatro anos de pesquisa.

Agradeço os Professores e membros da banca qualificadora, Fernando Antônio Novais e Pedro Puntoni, pelos comentários e sugestões, e pelo constante incentivo nesses anos de convivência acadêmica.

Aos Professores Luciano Raposo de Almeida Figueiredo e Marco Pamplona agradeço pelas oportunidades dos debates realizados durante as ANPUHs, no âmbito do grupo temático "Revoltas, Motins e Insurreições". Ao Luciano Figueiredo, em especial, agradeço pelas oportunidades de publicação na Revista de História, e pela amizade construída nesses anos. Sou sua fã, você sabe.

Agradeço o Professor Pedro Cardim pela orientação durante a pesquisa realizada em Lisboa e pelo acesso aos trabalhos sobre São Tomé e Príncipe na biblioteca do Centro de História do Além-Mar. Ao Professor Tiago C. P. dos Reis Miranda agradeço pelas observações em relação à política portuguesa de concessão de territórios. Aos dois sou profundamente grata pelo carinhoso acolhimento institucional na belíssima Lisboa. 
Aos amigos em Lisboa: Maria Manuel (Miúcha) Marques, Claudiany Pereira, Ana Letícia Fauri Gaspar, Gefferson Ramos, Nelson Mendes Cantarino e Francismar Alex Lopes de Carvalho. A todos vocês agradeço pela intensa e animada convivência naquele delicioso verão de 2009. Que a nossa amizade continue firme e forte!

Agradeço aos meus amigos cariocas: Carlos Ziller Camenietzki (Xuxu), Rômulo Siqueira Batista e João Carlos Guedes Pereira (Goméia), pelas inúmeras acolhidas no belíssimo balneário para as minhas temporadas entusiasmadas de pesquisa e samba! Ao Rômulo, em especial, agradeço pelo carinho e pela linda amizade em momentos importantes na minha vida.

Agradeço à querida Marieta Pinheiro de Carvalho por compartilhar o interesse pela trajetória política de d. Fernando José de Portugal e Castro, e pela parceria que está por vir!

Agradeço à Carolina Sá e ao Ancelmo Góis, da TV Brasil, pelo convite e pela gentileza com a qual vocês me trataram durante a gravação do programa sobre os 210 anos do enforcamento dos réus da Conjuração Baiana de 1798. O programa ficou bonito de se ver!

Aos meus amigos soteropolitanos: Rafael Faria Lima, que sempre me recebeu em seu chatô de braços abertos, com carinho e deliciosas conversas. À Aninha Franco, por me abrir as portas de sua incrível "República" no Pelourinho.

À Aninha Franco, ao Paulo Dourado e ao Dody Só: sou imensamente grata por vocês compartilharem com o público a belíssima peça "Búzios, a Revolta dos Alfaiates", encenada na Concha Acústica do Teatro Castro Alves em novembro de 2011.

Ao Urano Andrade, pela amizade e pela força com a documentação sobre 1798. Ao Afrânio Simões por compartilhar a paixão pela história da nossa Bahia no final do século XVIII. À Avanete de Sousa Pereira pela força de sempre e pelo convite, junto com Maria das Graças, para a publicação de artigo no belíssimo livro sobre as lutas pela Independência política na nossa linda Bahia. À Prof ${ }^{a}$ Maria José Rapassi Mascarenhas pela amizade e pelas inspiradoras conversas sobre a consolidação da elite baiana!

Ao Prof ${ }^{\mathrm{o}}$. Ubiratan de Castro Araújo, presidente da Fundação Pedro Calmon, e ao historiador Carlos Silva Jr. pela oportunidade de falar sobre os réus da Conjuração Baiana de 1798, exatamente no dia 12 de agosto de 2011, no Palácio Rio Branco, em Salvador.

À Professora Consuelo Pondé e ao Professor Jaime Nascimento pelo carinho e atenção com a qual vocês me receberam no Instituto Geográfico e Histórico da Bahia para me ouvir falar sobre Braz do Amaral, na Praça da Piedade, em Salvador, 213 anos depois do enforcamento dos réus da Conjuração Baiana de 1798.

Ao Professor Luís Henrique Dias Tavares sou imensamente grata pelo incentivo à pesquisa e pela linda amizade construída desde os idos de 2007. Luís Henrique e sua esposa, D. Laurita, sempre me receberam de braços abertos e sempre foram 
extremamente afetuosos comigo durante almoços e tardes em que tomamos sorvetes de cupuaçu conversando sobre a História da Bahia. Carinho e admiração eternos!

Ao João Jorge Santos Rodrigues, meu querido presidente do Olodum, por tudo, que não é pouco e sempre será muito. Porque o tempo feliz da liberdade, o tempo em que todos seremos irmãos, o tempo em que todos seremos iguais na nossa belíssima Bahia ainda está por vir. À Mara Felipe e à Cristina Calaccio por me convidarem a fazer parte do belíssimo evento realizado na UNEB, pela admirável Escola Olodum, em agosto de 2012, sobre a "Revolta dos Búzios".

Ao querido Elias Sampaio, Secretário da Promoção da Igualdade Racial do Estado da Bahia, pela amizade que começou a ser construída em 2011. Como você sabe, a nossa "Primeira Revolução Social Brasileira", apesar de alguns ensaios, ainda está para ser feita. Sigamos juntos!

Agradeço ao presidente do Olodum, João Jorge dos Santos Rodrigues e ao cineasta Joel Zito Araújo, queridos, pelo convite para participar do processo de roteirização do filme sobre a Conjuração Baiana de 1798.

Aos queridos Elias Sampaio, João Jorge dos Santos Rodrigues, Ubiratan Amorim Toledo Miranda e Maurício Pestana agradeço por me convidarem a compor o grupo de bambas que batalhou pelo belíssimo samba enredo da nossa querida Nenê de Vila Matilde para o carnaval de 2013: "Da Revolta dos Búzios à atualidade, Nenê canta a Igualdade”. Estaremos juntos na avenida!

Agradeço à Diretoria da Escola de Samba Nenê de Vila Matilde, que me ouviu falar sobre a Conjuração Baiana de 1798, durante a primeira etapa de escolha do samba enredo, em especial ao querido Presidente Mantega, Betinho, Léa, Magoo, Márcio, Eduardo Caetano e Lúcia Helena da Silva. Estamos juntos!

Aos meus amigos da Famesp: Persio Nakamoto, Alícia Eiras, Isilda Guimarães, Patrícia Rodrigues, Elenir Carillo, Mirian Fiori, Solange Vaini, Luciana Moura Abreu, Edvaldo, André Dalphino, Daniela Vaz, Aline e Cleber Feijó. Agradeço a cada um de vocês pelo carinho e pela amizade!

Agradeço aos meus recentes amigos da UniABC, sobretudo ao coordenador do curso de História Fábio Pires Gavião e ao professor Renato Dotta pela força e torcida nesses últimos meses de convivência.

Agradeço ao Marquinhus, que sempre torceu muito para que esse momento chegasse. Mesmo de longe você é posseiro, de posse mansa e pacífica, de um pedaço do meu coração.

Agradeço ao Wolfgang Lenk, queridíssimo, pela amizade construída, pelos inúmeros bate-papos históricos durante várias viagens para congressos e seminários, pelas leituras dos meus textos e pelo constante incentivo para que a pesquisa fosse concluída!

Agradeço imensamente ao Aldair Carlos Rodrigues, querido, por me esclarecer questões importantes sobre os Familiares do Santo Ofício. Sem a sua ajuda dificilmente 
eu conseguiria nomear os Familiares arrolados nos boletins manuscritos da Conjuração Baiana de 1798.

Agradeço à minha amiga querida Daniela Krogh e seu divertido marido, Nicolai Krogh, pelos deliciosos bate-papos, pelo carinho de sempre comigo e com a minha turminha e pelo divertido réveillon no Krogh's!

Agradeço ao Carlos Henrique Barbosa Gonçalves, que de companheiro nos cursos do Professor Fernando Novais se transformou em um dos meus grandes amigos, que dividiu comigo momentos de aflição e alegria nos nossos cafés jacobinos no Girondino do centro de São Paulo. Valeu pela força de sempre!

Agradeço aos meus irmãozinhos Igor Renato Machado Lima e Serginho, por estarem sempre por perto, pela nossa cumplicidade e pelas deliciosas risadas! Estaremos juntos, sempre!

Agradeço ao Fábio Betioli Contel, que nos últimos quatro meses do doutorado foi um companheiro incansável, sempre transformando tudo em tanto. Carinho eterno por você.

Por fim, nessa versão corrigida, gostaria de agradecer imensamente aos membros da banca de doutorado pelas generosas arguições: $\operatorname{Prof}^{\circ} \operatorname{Dr}^{\circ}$ Luciano Figueiredo, $\operatorname{Prof}^{\mathrm{o}} \operatorname{Dr}^{\circ}$ Carlos Gabriel, $\operatorname{Prof}^{\mathrm{a}} \operatorname{Dr}^{\mathrm{a}}$ Iris Kantor e $\operatorname{Prof}^{\mathrm{o}} \operatorname{Dr}^{\mathrm{o}}$ Fernando Novais. 
Pobre colono: eis sua contradição posta a nu. Deveria, dizem, como faz o gênio, matar as vítimas de suas pilhagens. Mas isso não é possível. Não é preciso também que as explore? Não podendo levar o massacre até ao genocídio e a servidão até ao embrutecimento, perde a cabeça, a operação de desarranjo e uma lógica implacável há de conduzi-la até à descolonização. Não de imediato. A princípio o europeu reina: já perdeu, mas não se dá conta disso; ainda não sabe que os indígenas são falsos indigenas; atormenta-os, conforme alega, para destruir ou reprimir o mal que há neles. Ao cabo de três gerações, seus instintos perniciosos não renascerão mais. Que instinto? Os que compelem os escravos a massacrar o senhor? Como não reconhece nisto a sua própria crueza voltada contra ele? A selvageria dos camponeses oprimidos, como não reencontra nela sua selvageria de colono, que eles absorveram por todos os poros e de que não estão curados? A razão é simples. Esse personagem arrogante, enlouquecido por todo o seu poder e pelo medo de o perder, já não se lembra realmente que foi um homem: julga-se uma chibata ou um fuzil; chegou a acreditar que a domesticação das "raças inferiores" se obtém através do condicionamento dos seus reflexos. Negligencia a memória humana, as recordações indeléveis; e depois, sobretudo, há isto que talvez ele jamais tenha sabido: nós não nos tornamos o que somos senão pela negação íntima e radical do que fizeram de nós. Três gerações? Jean Paul Sartre, Prefácio de "Os condenados da Terra", de Frantz Fanon. 


\section{Resumo}

Durante as investigações da Conjuração Baiana de 1798, um grupo de homens de muita "opulência e luzimento", qualificados por Luís dos Santos Vilhena de "corporação dos enteados", fez "pronta-entrega" de seus escravos à justiça para livrarem-se da acusação de prática sediciosa no final do século XVIII, na capitania da Bahia. Esse episódio foi o ponto de partida para se comprovar a participação de pessoas dos médios e altos setores da sociedade soteropolitana na Conjuração Baiana de 1798, cujas demandas explicitadas nos boletins manuscritos eram inconciliáveis em seus termos, uma vez que o projeto político dos médios setores, os milicianos, vislumbrava a mudança dos hierarquizados critérios sociais que os impediam de participarem do universo político e ascenderem na carreira militar, e o projeto político dos altos setores, a corporação dos enteados, objetivava a conservação das regras do Sistema Colonial, que até então os tratava como "enteados" nas dinâmicas políticas e econômicas do Império Português. A documentação demonstra que o recrudescimento do pacto colonial anunciado pelas reformas modernizantes de d. Rodrigo de Sousa Coutinho desencadeou uma tomada de consciência da exploração colonial, fazendo com que os altos setores da sociedade soteropolitana do final do século XVIII reivindicassem a internalização de seus interesses econômicos e a manutenção de seus privilégios ameaçados com a possibilidade do fím dos monopólios, dos morgados, da mudança na forma de arrematação dos ofícios de fazenda e justiça, e da manutenção da prorrogação da arrematação dos dízimos para os negociantes portugueses. Após uma aliança programática com o contingente armado da capitania da Bahia, os médios e altos setores do Partido da Liberdade deflagraram o movimento com a publicação dos boletins manuscritos, explorando ao limite os dois principais medos no horizonte de expectativas da coroa portuguesa naquele conflituoso final de século: a miragem do livre comércio e a invasão francesa. Abertas as devassas para a investigação dos autores dos boletins manuscritos e dos partícipes do movimento, os altos setores recuaram, entregaram seus escravos à justiça e formularam as principais culpas que condenaram à pena de morte homens dos médios setores. Tratam-se, portanto, de elementos que permitem a análise da Conjuração Baiana de 1798 como um movimento de contestação política ocorrido em duas fases, durante o período de 1796-1800, contando com a efetiva participação dos altos e médios setores da sociedade soteropolitana da época. $\mathrm{O}$ enforcamento em praça pública dos réus da Conjuração Baiana de 1798, portanto, é paradigmático do fato de que projeto político vencedor foi o conservador, na medida em que a coroa portuguesa empreendeu uma série de soluções de compromisso com a corporação dos enteados, garantindo-lhes a internalização de seus interesses e a manutenção de seus privilégios, que os constituíam no setor dominante daquela sociedade, base social fundamental para a sustentação do poder monárquico português continuar a governar a conflitualidade no interior dos setores dominantes da sua principal colônia.

\section{Palavras-chave: Conjuração Baiana de 1798; Movimento social.}




\section{Abstract}

During the investigations of the Conjuração Baiana of 1798, a group of men with "opulence and brightness" qualified by Luís dos Santos Vilhena like the "corporação dos enteados", made a "immediate delivery" of their slaves to justice to rid themselves of charges of seditious practices in the late eighteenth century, at the captaincy of Bahia. This episode was the starting point to prove the participation of people from middle and higher social sectors of Salvador in the Conjuração Baiana of 1798, whose demands spelled out in manuscript bulletins were incompatible on their own terms, once the political project of the middle sectors, the militiamen, glimpsed the change of hierarchical social criteria that prevented them from participating in the political world and ascend in the military, and the political project of the upper sector, the corporação dos enteados, aimed at keeping the rules of the Colonial System, which until then was treated as "enteados" in the political and economic dynamics of the Portuguese Empire. The documentation shows that the intensification of the colonial pact announced by the modernizing reforms of $\mathrm{d}$. Rodrigo de Sousa Coutinho triggered an awareness of colonial exploitation, making new claims of the higher social sectors of Salvador in the late eighteenth century to the internalization of its economic interests and maintain their privileges threatened with the possibility of the end of monopolies, of the morgados, the change in the auction of justice and treasury permissions, and maintaining the extension of auction of tithes to the Portuguese merchants. After a programmatic alliance with the armed contingent of the captaincy of Bahia, the middle and upper sectors of the Partido da Liberdade sparked the movement with the publication of manuscript bulletins, exploring the limits the two main fears on the horizon of expectations of the Portuguese crown at the end of that turbulent century: the mirage of free trade and the french invasion. With the start of the investigations to define the authors of these manuscripts and from participants of the movement, the higher sectors retreated, delivering their slaves to justice and formulating the main proves that condemned to death those men from the middle social sector. These elements allow the analysis of Conjuration Baiana of 1798 as a movement of political contestation that occurred in two phases, during the 1796-1800 period, with the effective participation of upper and middle social sectors of Salvador at the time. The hanging in public square of the defendants of the Conjuração Baiana of 1798, therefore, is paradigmatic of the fact that the winner's political project was the conservative, in that sense that the Portuguese crown undertook a series of compromises with the corporação dos enteados, ensuring them to internalize their interests and maintain their privileges, which allows them to constitute the dominant sector of that society, and was fundamental to sustaining the continuance of Portuguese monarchy to govern the conflict within the dominant sectors of its main colony.

\section{Key-words: Conjuração Baiana de 1798; Social Movement.}





\section{Sumário}

Introdução

01

Cap. 1 “Tempos de Tensão: 1796-1798"

35

* 1.1 "A capitalidade da Bahia setecentista no Império 36 Português"

* 1.2 "D. Fernando José de Portugal e Castro e a corporação dos $\mathbf{7 6}$ enteados"

Cap. 2 "Tempos de Contestação: 1797-1798"

114

2.1 Os impactos da política reformista de d. Rodrigo de Sousa $\mathbf{1 1 5}$ Coutinho na capitania da Bahia no final do século XVIII

2.2 Os Boletins Manuscritos: demandas e agentes políticos

154

Cap. 3 "Tempos de Negociação: 1798-1800"

179

3.1 A Devassa das Devassas

180

* 3.2 As negociações em 1799

Conclusões

Documentação 


\section{Introdução}

\section{1. \\ o tema}

No final do século XVIII, a Capitania da Bahia passava por um processo de expansão mercantil e demográfica, enquanto as ruas e ladeiras das cidades alta e baixa de Salvador eram palcos de várias agitações políticas ${ }^{1}$. Por volta de 1798, Salvador tinha cerca de 60.000 habitantes $^{2}$ e a expansão mercantil provocou uma rápida e constante elevação dos preços dos produtos de exportação e de consumo, provocando um clima de prosperidade para os que estavam ligados à produção e ao grande comércio. Para a maioria da população, livres e pobres que viviam de ofícios mecânicos, no entanto, a situação beirava à calamidade, pois a alta de preços, principalmente da carne e da farinha de mandioca, não foi acompanhada pela alta dos jornais ${ }^{3}$.

Entre as várias agitações políticas que ocorreram na cidade, no dia 12 de agosto de 1798, a população de Salvador foi surpreendida pelo teor dos boletins manuscritos afixados em prédios públicos, alguns dos quais com a seguinte mensagem: “O Povo Bahinense e Republicano ordena, manda e quer que para o futuro seja feita a sua

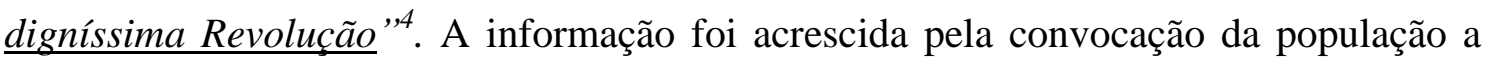
participar do levante projetado pelo Partido da Liberdade: um grupo que se intitulava Anônimos Republicanos ${ }^{5}$. Ainda que as mensagens fizessem referência ao tempo futuro,

\footnotetext{
${ }^{1}$ Affonso Ruy. História da Câmara Municipal da Cidade de Salvador. Salvador: Câmara Municipal de Salvador, 2003; A.J.R. Russel-Wood. Fidalgos e filantropos: a Santa Casa da Misericórdia da Bahia, 1550-1755. Brasília: UnB, 1981; José Jobson de Andrade Arruda. A circulação, as finanças e as flutuações econômicas. In Nova história da expansão portuguesa, o império luso-brasileiro 1750-1822. Lisboa: Estampa, 1986, vol. VIII; Kátia Mattoso, Da Revolução dos Alfaiates à riqueza dos baianos no século XIX. Salvador: Corrupio, 2004.; Maria José Rapassi Mascarenhas. Fortunas coloniais - Elite e riqueza em Salvador 1760 - 1808. Tese de Doutorado, DH/FFLCH/USP, 1999; Stuart B Schwartz. Segredos Internos: engenhos e escravos na Sociedade Colonial: 1550-1835. São Paulo: Cia Das Letras/ CNPq, 1988; Stuart B Schwartz. Burocracia e sociedade no Brasil colonial: o Tribunal Superior da Bahia e seus desembargadores, 1609-1751. São Paulo: Companhia das Letras, 2011;Vera Lúcia Amaral Ferlini. Terra, Trabalho e Poder: o mundo dos engenhos no Nordeste colonial. Bauru: EDUSC, 2003.

${ }^{2}$ Cf. Luís dos Santos Vilhena. Recopilação de Notícias Soteropolitanas e Brasílicas. Salvador: Itapuã, 1969,3 vols.

${ }^{3}$ Kátia M. de Queirós Mattoso, Presença Francesa no Movimento Democrático Baiano de 1798. Salvador: Itapuã, 1969.

${ }^{4}$ Kátia M. de Queirós Mattoso. Presença Francesa no Movimento Democrático Baiano de 1798. Salvador: Itapuã, 1969, pp. 150-159. Ler, especialmente, os pasquins nº 4, 5, 6, 7 e 8. Grifo meu.

${ }^{5}$ Idem.
} 
as autoridades dos dois lados do Atlântico não desconsideraram o peso dos termos veiculados nos boletins: liberdade, república e revolução, que naquela conjuntura compunham a cadência da Revolução Americana (1776), Revolução Francesa (1789) e Revolução escrava em São Domingo (1791).

As autoridades locais agiram rapidamente, iniciando uma duvidosa investigação para se descobrir e punir os autores dos boletins manuscritos que, em razão dos termos veiculados, foram qualificados de pasquins sediciosos. Como era de se esperar, d. Fernando José de Portugal e Castro, governador-general da Bahia, imediatamente ordenou que fosse aberta uma devassa para se descobrir o(s) autor(es) de tão "odiosa empresa". Para tanto, designou, por Portaria de 13 de agosto de 1798, o Desembargador Ouvidor Geral, com vezes de Corregedor do Crime, Doutor Manoel Magalhães Pinto Avellar de Barbedo ${ }^{6}$.

De acordo com a documentação, para dar início às investigações, o Secretário de Estado e Governo do Brasil, José Pires de Carvalho e Albuquerque lembrou ao governador o "modo livre e atrevido de falar" do Requerente do Tribunal da Relação da Bahia, o pardo Domingos da Silva Lisboa, sugerindo-lhe que confirmasse a suspeita e comparasse a letra dos boletins com algumas petições que porventura o Desembargador pudesse encontrar na casa do dito requerente ${ }^{7}$. Acatando a sugestão de José Pires de Carvalho e Albuquerque, no dia 21 de agosto de 1798, o Desembargador Avellar de Barbedo, concluiu que " a Letra dos mesmos [boletins] segundo nos pareceo he do dito Domingos da Silva Lisboa posto que disfarçada [...] ",8.

Dias depois, outros dois boletins em formas de cartas foram encontrados na Igreja do Carmo, colocando em xeque a autoria e o modo pelo qual as autoridades chegaram ao então culpado que, àquela altura, encontrava-se preso no Segredo (Cadeia) do Tribunal da Relação. Na primeira carta, o Prior dos Carmelitas Descalços era informado que tinha sido escolhido por plebiscito para no futuro ser o Chefe em Geral

\footnotetext{
${ }^{6}$ Cf. "Devassa a que procedeo o Desembargador Ouvidor Geral, com vezes de Corregedor do crime da Coroa, o Doutor Manoel Magalhães Pinto e Avellar de Barbedo, na conformidade da Portaria do Ilmo. Exmo. Governador e Capitão General desta Capitania, sobre a factura, e publicação de vários papéis sediciozos, e revolucionários, que aparecerão nesta cidade do dia doze de Agosto de 1799". In: Autos da Devassa da Conspiração dos Alfaiates, Salvador: Arquivo Público do Estado da Bahia, 1998, pp. 31-32. Doravante ADCA. Chamamos a atenção para o fato de que o ano da publicação dos pasquins sediciosos é 1798, e não 1799 como consta na documentação da devassa.

${ }^{7}$ Cf. Auto de Exame, e combinação das Letras dos pesquins (sic), e mais papeis sedicciozoz que apparecerão nas esquinas, ruas e Igrejas desta Cidade que se achão incorporados na Devassa, que está debaixo do $N^{o} .1$ e do papel em que elles estão escritos, com as letras de Domingos da Silva Lisboa nas peticoens, que forão achadas em sua caza e com o papel limpo, que ahi também se achou, e tudo se acha junto ao auto da achada, e aprehenção constante do appenso $N^{\circ}$. 9. In: ADCA, 89-90.

${ }^{8}$ Idem, p. 90.
} 
da Igreja Bahinense. A segunda carta foi para o governador, d. Fernando José de Portugal e Castro:

"Illustrissimo e Excellentissimo Senhor, o Povo Bahinense, e Republicano na secção de 19 do prezente mez houve por bem eleger; e com efeito ordenar que seja Vossa Excellencia invocado compativelmente como cidadão Prezidente do Supremo [Tribu]nal da Democracia $B$ [ahinense] para as funcoens, da futura revolução, que segundo o Plebiscito se dará no prezente pelas duas horas da manhã, conforme o prescripto do Povo. Espera o Povo que Vossa Excellencia haja por bem o exposto. Vive et vale",9.

Não obstante ao modo pouco ortodoxo de se descobrir o autor dos pasquins, d. Fernando José de Portugal e Castro ordenou que o Desembargador Avellar de Barbedo fizesse um novo exame de comparação das letras dos bilhetes. Dessa feita, o resultado foi a descoberta de três petições na Secretaria de Estado que provaram que o autor dos boletins manuscritos e dos bilhetes era Luiz Gonzaga das Virgens e Veiga, homem igualmente pardo e soldado do Primeiro Regimento de Linha de Salvador e Quarta Companhia de Granadeiros ${ }^{10}$. Ocorre que dessa vez pesou sobre o réu um "requerimento atrevido" enviado pelo acusado para que d. Fernando

"[...] o nomeasse Ajudante do quarto Regimento de Milícias desta Cidade, composto de homens pardos, alegando que estes devião ser igualmente attendidos que os brancos, a que não deferi, e que conservava em meu poder pela sua extravagância $[\ldots]^{, 11}$.

Por analogia ao teor da carta, o Desembargador chegou ao conteúdo dos pasquins sediciosos, uma vez que os papéis também "inculcavão aquela mesma igualdade entre os pardos, pretos e brancos". Isso posto, "faz não só conjecturar mas persuadir ser elle [Luiz Gonzaga das Virgens e Veiga], e não outrem o autor dos Papeis Sediciozos" $"$. Todavia, o governador mandou soltar Domingos da Silva Lisboa

\footnotetext{
${ }^{9}$ Outra relação feita pelo P. Fr. Joze D’Monte Carmelo, religiozo carmelita descalço. Instituto Histórico e Geográfico Brasileiro, doravante IHGB, Notícia da Bahia, tomo IV, Lata 402, manuscrito 69. Arquivo Histórico Ultramarino, inventário Castro e Almeida, Bahia, documentos avulsos, caixas: 41 a 82 . O documento "Outra relação ..." está integralmente transcrito na obra de Luís Henrique Dias Tavares. História da Sedição intentada na Bahia em 1798 (A Conspiração dos Alfaiates). São Paulo/Brasília: Pioneira/INL, 1975, pp. 123-137.

10 “Auto de combinação de letra dos pesquins [sic], e papeis sediciosos, que apparecerão nas esquinas, ruas e Igrejas desta Cidade, incorporados na Devassa debaixo do n. 1 com a letra de Luiz Gonzaga das Virgens nas peticoens que estão no appenso $n .4$ e papeis juntos por linha ao appenso $n$. 5 , e com a letra de Domingos da Silva Lisboa nas peticoens,...”. In: ADCA, vol. 1, pp.123-124.

${ }^{11}$ Biblioteca Nacional, doravante BN, Sessão de Manuscritos, I-28-26, 1, n. 13.

${ }^{12}$ Cf. Huma carta escrita pelo reo Luiz Gonzaga das Virgens ao Cadete Francisco Leonardo Carneiro, e
} 
apenas no dia 10 de novembro de 1798, comunicando ao Desembargador Avellar de Barbedo, no dia 24 de fevereiro de 1799, que o havia mandado prender novamente " $a$ vista de huma Reprezentação vocal [...] expondo-me que ocorrião outros [motivos] pellos quaes se devia praticar com elle semelhante procedimento",13.

A representação vocal a que se referia o governador era a denúncia de uma reunião na madrugada do dia 25 de agosto de 1798, no Campo do Dique do Desterro, atual Dique do Tororó, no qual os partícipes do movimento verificariam a quantidade de homens e armas para dar início ao levante e libertar Luiz Gonzaga das Virgens e Veiga, que àquela altura encontrava-se preso. A partir desse momento, as autoridades dos dois lados do Atlântico estavam às voltas de dois problemas que, comprovados, configuravam crime de lesa-majestade de primeira cabeça: descobrir os autores dos pasquins sediciosos e os partícipes do levante que instituiria no futuro a "República Bahinense".

A reunião no Campo do Dique do Desterro foi abortada pelas autoridades locais, e o esboço de uma "República Bahinense" foi uma jura que morreu sem oração na manhã de 8 de novembro de 1799, quando quatro homens livres, pobres e pardos foram enforcados e esquartejados na Praça da Piedade, em Salvador. Condenados como os “cabeças" da "projetada revolução”, os alfaiates Manuel Faustino e João de Deus do Nascimento, e os soldados Lucas Dantas de Amorim e Luiz Gonzaga das Virgens e Veiga foram considerados os protagonistas de um evento histórico conhecido até os dias de hoje como Conjuração Baiana de 1798.

\section{2.}

\section{A Conjuração Baiana de 1798 na historiografia}

No mestrado em História Social sobre a construção da memória história da Conjuração Baiana de 1798, defendido em $2007^{14}$, demonstrou-se que o trágico fim desses homens foi reputado pela historiografia oitocentista como uma anomalia social e manifestação da barbárie habilmente abortada pelas autoridades régias. Sob a pena dos

\footnotetext{
o rascunho de hum requerimento do mesmo reo, dirigido a Sua Alteza. In: ADCA, pp. 224-226. Os originais estão no Arquivo Público do Estado da Bahia, doravante APEB, maço 580, auto 21.

13 Cf. Cópia da Portaria do Illustríssimo e Excellentíssimo Governador e Capitão General desta Capitania derigida ao Dezembargador Ouvidor Geral do Crime, e Intendente da Polícia o Doutor Manoel de Magalhães Pinto de Avellar de Barbedo. In: ADCA, p. 91.

${ }^{14}$ Cf. Patrícia Valim. Da Sedição dos Mulatos à Conjuração Baiana de 1798: a construção de uma memória histórica. Dissertação de Mestrado, DH/FFLCH/USP, 2007.
} 
intelectuais do século XX, entretanto, o evento foi considerado como a mais popular das revoltas que antecederam a emancipação política do Brasil, em 1822. Após as comemorações do primeiro centenário da Independência do Brasil, percebe-se que a pena histórica encarregou-se não só de alargar as bases sociais do evento, originalmente circunscrita aos médios e baixos setores da sociedade baiana da época, como, a partir de uma inversão historiográfica dos polos das análises, transformou-o em um dos tournants da nossa história nacional ${ }^{15}$.

A partir do reconhecimento de que as revoltas populares, no oitocentos, significavam a tentativa "ilegítima" de a população livre citadina invadir os espaços políticos circunscritos aos homens virtuosos, na melhor tradição de Montesquieu, os historiadores demonstraram a baixa condição social dos enforcados em praça pública como impossibilidade de existir base social para a legitimação de projetos políticos de feição republicana.

Inácio Accioli reiterou a circunscrição social elaborada pelas autoridades em 1799, no que se refere à articulação dos protagonistas da revolta e seus princípios políticos, i.e., os homens livres e pobres como o único setor social simpático às ideias da França revolucionária ${ }^{16}$. John Armitage, por sua vez, reafirmou a baixa composição social dos partícipes da revolta - homens de cor da Bahia-, considerando-a como um dos desdobramentos do estado de infantilidade da civilização brasileira sob o domínio de Portugal ${ }^{17}$.

Francisco Adolfo de Varnhagen sofistica os argumentos e o método ao qualificar a revolta como uma Conspiração Socialista, um arremedo da Revolução em São Domingo protagonizado por homens de “ínfima qualidade”. Ao publicar quase integralmente o conteúdo dos pasquins sediciosos afixados em locais públicos da Salvador de 1798, na primeira edição de sua História Geral do Brasil, em 1853, Varnhagen procurou desqualificar o localismo e o republicanismo subjacente à revolta "habilmente abortada pelas autoridades régias"18. No entanto, Joaquim Caetano Fernandes Pinheiro, preocupado com os desdobramentos dos conteúdos dos pasquins

\footnotetext{
15 idem.

${ }^{16}$ Inácio Accioli de Cerqueira Silva. Memórias Históricas e Políticas da Província da Bahia. Bahia: Typ. Do Correio Mercantil, de Précourt, 1835, Tomo I. Este tomo com as anotações de Brás do Amaral equivale ao Tomo III, p. 17 da edição elaborada em 1931 pela Tipografia Oficial do Estado da Bahia.

17 João Armitage. História do Brasil. São Paulo: EDUSP, 1981. A 1a a edição inglesa é de 1836. A primeira edição brasileira é de 1837.

${ }^{18}$ Arquivo Histórico do Itamaraty, doravante AHI, códices 351-360, Lata 351, doc. A. A documentação analisada é a primeira edição de Varnhagen com anotações e alterações manuscritas pelo próprio autor para a publicação da segunda edição, em 1871.
} 
sediciosos, naquela conflituosa conjuntura de 1860, criticou a postura de Varnhagen no artigo A Conspiração de João de Deus, demonstrando o perigo de corrupção do tecido social quando os homens livres, pobres e pardos tentaram fazer política em $1798^{19}$.

O problema nessa perspectiva de análise já não era mais os projetos políticos republicanos, pois para o cônego Fernandes Pinheiro a administração de Pedro II era sensível às "quiméricas utopias" de homens como Cipriano Barata; não dos homens livres, pobres e pardos para quem o fazer política em 1798, não passou de "conciliábulos, compostos das fezes da população bahiana, sem bases determinadas, reunidos em um lugar público e terminado em um botequim”. Controvérsias à parte, o que estava em causa para ambos os autores, no século XIX, era a unidade nacional e a manutenção da clivagem social no universo da política, em um momento em que os setores populares ganhavam as ruas com vários motins.

Com efeito, ainda que a Conjuração Baiana de 1798 tenha sido integrada como um dos fatos que compuseram a história pátria oitocentista, Francisco Adolfo de Varnhagen e Joaquim Caetano Fernandes Pinheiro, sobretudo, reafirmaram não só baixa composição social como a circunscrição geográfica do evento. Como homens de letras e da política oitocentista, foram além ao justificarem ideologicamente a punição exemplar, pois definir os sujeitos da revolta - homens livres, pobres e pardos enforcados em praça pública - para o tema da república, no século XIX, foi o ângulo pelo qual os autores demonstraram que a efetivação de um projeto republicano estava previamente fracassada, porque fora vislumbrada por um setor que não participava e nem deveria participar do universo da política.

Essa questão não é de pouca relevância, uma vez que ela foi a via pela qual parte dos historiadores que versaram sobre a Conjuração Baiana de 1798, no século XX, perceberam certo grau de coerência entre a tentativa de participação política dos setores populares e a ideia de república, concebida como desejo de autonomia baiana do jugo português e, depois da Revolução de 1930, de autonomia nacional.

Foi a partir da descentralização historiográfica, com a fundação dos Institutos Históricos e Geográficos regionais, na segunda década do século $\mathrm{XX}$, que os historiadores baianos Francisco Borges de Barros e Braz do Amaral deram início ao processo de inversão historiográfica dos polos das análises sobre a revolta baiana de

\footnotetext{
${ }^{19}$ Cf. Joaquim Caetano Fernandes Pinheiro. A Conspiração de João de Deus, Revista popular, tomo VIII, p 218-221, 1860. BN, sessão de obras raras, PR-SOR-03143[1-8].
} 
1798, no oitocentos, chamando a atenção, de maneira distinta, para o lugar de destaque que a Bahia deveria ocupar no processo de formação do Estado brasileiro.

Em sua análise, Francisco Borges de Barros ressalta o papel da maçonaria como o centro difusor das ideias libertárias e práticas sediciosas que fundamentaram as ações dos partícipes do evento: a fina flor da sociedade baiana de 1798, cujo desejo de mudança e o fim do domínio português foram a cadência das ações de homens como José da Silva Lisboa, Cipriano Barata e Francisco Agostinho Gomes ${ }^{20}$. Amplia-se a base social do evento sem desconsiderar o papel dos baixos setores da sociedade baiana da época, pois ao comparar os quatro homens enforcados em praça pública a Tiradentes, Francisco Borges de Barros demonstra que, como em qualquer "revolução", eles foram a linha de frente.

Contudo, foi Braz do Amaral quem realmente inverteu os polos das análises oitocentistas no que se refere à punição exemplar, chamando a atenção para o sangue dos réus enforcados no patíbulo público, em 1799, significar a generalização social do desejo de independência do domínio português. Ao chamar a atenção para a participação dos vários setores da sociedade baiana de 1798, o autor dá os primeiros passos para a ideia de cooperação de classe em torno de um projeto político coletivo, como um "crescendo de tomada de consciência" 21 . O resultado desse processo de inversão historiográfica do viés depreciativo das análises oitocentistas foi transubstanciação da Conjuração Baiana de 1798 em um evento de forte identificação política regional.

Tudo mudou com a Revolução de 1930. A partir desse momento, a Conjuração Baiana de 1798 deixa de ser um evento de identificação regional para tornar-se o representante das mais profundas aspirações de amplos setores da sociedade brasileira. A Revolução Burguesa será a cadência das análises de Caio Prado Júnior e Affonso Ruy, seja para demonstrar a prática revolucionária para que ela efetivamente aconteça, seja para entender as razões pelas quais ela ainda não aconteceu. Seja como for, o tom será o das utopias e da esperança por efetivas transformações sociais.

Embora a interpretação de Caio Prado sobre a Conjuração Baiana de 1798 seja breve, ela representa uma inflexão do conhecimento até então elaborado sobre o evento,

\footnotetext{
${ }^{20}$ Francisco Borges de Barros. Primórdios das Sociedades Secretas na Bahia. In: Anais do Arquivo Público do Estado da Bahia, vol. XV, pp. 44-45, 1928. Cumpre destacar que Francisco Borges de Barros não cita a referência de nenhum documento para a interpretação da Conjuração Baiana de 1798.

${ }^{21}$ Braz Hermenegildo do Amaral. A Conspiração Republicana da Bahia de 1798. Rio de Janeiro: Imprensa Nacional, 1926. Conferência realizada no Instituto Histórico e Geográfico Brasileiro, em 25 de junho de 1926.
} 
uma vez que o autor vê nos pressupostos revolucionários de Cipriano Barata a contradição interna da colonização portuguesa no final do século XVIII e, consequentemente, o desdobramento de influências externas. Para Caio Prado Júnior, a situação da Bahia colonial, no final do século XVIII, evidenciada pela tradicional estrutura agrário-exportadora, deflagrou as razões internas do conflito, já suficientemente agravadas pelos desdobramentos de um fenômeno mais amplo - o desenvolvimento do capitalismo comercial ${ }^{22}$.

Ao observar a centralidade do comércio europeu na análise sobre a colônia, Caio Prado afirma que todos os níveis da sociedade colonial foram organizados para atender às exigências do negócio mercantil, cujo sentido é a atenção às necessidades de consumo alheias. Nesse particular, para o autor "no Brasil-Colônia, a simples propriedade de terra, independente dos meios de a explorar, do capital que a fecunda, nada significa. Nisso distingue a nossa formação da Europa Medieval saída dos bárbaros, 23.

Uma década depois, baseando-se nas teses dogmáticas do Partido Comunista Brasileiro, para Affonso Ruy, a revolução articulada na Bahia e descoberta em 1798 mais não foi que o último marco da inquietação nacionalista que encheu todo o século XVIII, na transitoriedade que atingiria o ápice na revolução pernambucana, em $1817^{24}$. O autor encadeou em sua análise a Conjuração Baiana de 1798 como um crescendo de tomada de consciência, a partir da Inconfidência Mineira de 1789, permitindo-lhe qualificar o evento como a "Primeira Revolução Social Brasileira".

$\mathrm{Na}$ análise de Affonso Ruy a principal questão é práxis política de uma Revolução Burguesa malograda, na qual coube aos membros da elite baiana de 1798 a função de doutrinarem os proletários - alfaiates e soldados livres, pobres e pardos -, preparando-os para a ruptura com as formas de poder do Antigo Regime, a Independência do Brasil e a implantação de um novo regime de governo que inauguraria, enfim, uma nova era de progresso social.

Nesse caso, para o autor, nem a burguesia - a elite baiana - nem o proletariado homens livres e pobres - estavam preparados para cumprir suas "missões históricas".

\footnotetext{
${ }^{22}$ A edição utilizada nesta tese é a de 1975. Ler: Caio Prado Júnior. Cipriano Barata (1764-1838). In: Evolução Política Brasileira e outros estudos - Ensaio de interpretação materialista da História do Brasil. São Paulo: Brasiliense, 1975, $9^{\text {a }}$. edição. Alguns trabalhos afirmam que a primeira edição da obra data de 1946, mas de acordo com Florestan Fernandes, a primeira edição do livro é de 1933. Cf. Florestan Fernandes. A obra de Caio Prado nasce da rebeldia moral. Folha de São Paulo, 7 de setembro de 1991.

${ }^{23}$ Caio Prado Júnior, op.cit., p. 18.

${ }^{24}$ Affonso Ruy. A Primeira Revolução Social Brasileira. São Paulo: Cia. da Editora Nacional, Coleção Brasiliana, vol. 217, 1978, p. 9.
} 
Essa ideia está, sem dúvida, ligada às proposições marxistas em identificar uma determinada classe social com um "devir" histórico específico, no qual a burguesia "encarna" o espírito de cada época histórica, configurando-se em uma força social transformadora, superior às suas possibilidades históricas efetivas, para levar a cabo o processo revolucionário $^{25}$.

A partir de meados da década de sessenta do século XX, os estudos históricos no Brasil começaram a passar por uma profunda renovação, com a crescente produção universitária ligada à implantação dos programas de pós-graduação. Tais programas estavam influenciados, por um lado, pelas vertentes marxistas e, por outro, pelas atividades dos pesquisadores franceses ligados à revista Annales, conhecidos pela aproximação com as outras ciências humanas. A questão com a qual essa geração estava às voltas, nem sempre orientada por um mesmo conjunto de conceitos e problemas, era o estudo das mudanças sociais e políticas no Brasil, em perspectiva histórica. A crítica era anti-imperialista e o método era o "revisionismo radical"26, que desaguaria nos estudos mais sistemáticos sobre a dependência brasileira.

Nesse ambiente, Fernando Antônio Novais ${ }^{27}$, radicalizando as teses de Caio Prado Júnior, interpreta os acontecimentos ocorridos no período de 1777-1808, da colonização brasileira, como parte de um fenômeno emergente da expansão do capitalismo industrial, de novos padrões de dominância que redefiniriam as condições de ordenamento das contradições internas de cada uma das partes constitutivas do Império Português. Para o autor, o Antigo Sistema Colonial, organizado como um mecanismo de aceleração da acumulação primitiva, constituiu-se em fator vital para a passagem do capitalismo comercial para o capitalismo industrial, mas, em contrapartida, fomentou a emergência de padrões incompatíveis com esse mesmo sistema de colonização mercantilista.

Exemplos desses padrões incompatíveis, a seu ver, são as revoltas coloniais ocorridas no Brasil no final do século XVIII e início do século XIX. Com efeito, justamente porque a tese do autor visa demonstrar a Crise do Antigo Sistema Colonial, a Conjuração Baiana de 1798 é interpretada como o desdobramento da irreversibilidade desse processo. O autor afirma que na Bahia de 1798, “a contestação do colonialismo

\footnotetext{
${ }^{25}$ Cf. Caio Prado Júnior, op.cit.

${ }^{26}$ Expressão cunhada por Carlos Guilherme Mota. A ideologia da cultura brasileira (1933-1974) pontos de partida para uma revisão histórica. São Paulo: Ática, $5^{\text {a }}$. edição, 1985, p. 48.

${ }^{27}$ Fernando Antônio Novais. Portugal e Brasil na Crise do Antigo Sistema Colonial (1777-1808). São Paulo: Hucitec, 1995. 6 ${ }^{\mathrm{a}}$. edição.
} 
do Antigo Regime envolveu efetivamente os estratos mais subalternos da ordem social e radicalizou no limite as propostas de transformação política,28. Transcendeu-se, com efeito, a tomada de consciência da situação colonial e projetou-se a mudança, pois a seu ver, a trama ocorrida na Salvador de 1798 mais não foi que a face soteropolitana da Crise do Antigo Sistema Colonial. A demonstração da irreversibilidade de um longo processo de ruptura que culminou no nosso peculiar processo de Independência ${ }^{29}$.

A relevância da análise reside na própria ideia de Crise do Sistema Colonial elaborada por Fernando Antônio Novais, entendida como o conjunto de tendências políticas e econômicas que forcejavam no sentido de distender ou mesmo desatar os laços de subordinação que vinculavam as colônias ultramarinas às metrópoles europeias $^{30}$. O que vale afirmar que se do ponto de vista econômico esse conceito de Crise do Sistema pode coexistir com uma etapa de franca expansão da produção e do comércio colonial - como é o caso da Bahia do final do século XVIII -, do ponto de vista político, não lhe restava outra situação que não fosse a sua própria superação.

Não obstante a rima ser infame, o que importa é que as implicações que Fernando Antônio Novais faz acerca da Crise do Antigo Sistema Colonial foram a cadência das análises que István Jancsó e Carlos Guilherme Mota elaboraram sobre a Conjuração Baiana de 1798, considerando o nacionalismo a via de emancipação política e superação das desigualdades sociais, intrínsecas à formação do Estado brasileiro.

István Jancsó analisa a Conjuração Baiana de 1798 no quadro geral das transformações derivadas da Crise do Antigo Sistema Colonial, uma vez que foi:

"no interior de um movimento permanente de transformações sociais, de propostas e práticas, de lutas, vitórias e derrotas que representam o processo de acumulação coletiva da experiência política dos segmentos sociais que formam o conjunto da sociedade brasileira, experiência que será, em última análise, uma das bases sobre a qual se construirá o Estado nacional brasileiro" 31 .

Para o autor, a peculiaridade da Conjuração Baiana de 1798 em relação às outras revoltas do final do século XVIII, reside na participação de homens de distinta condição

\footnotetext{
${ }^{28}$ Cf. Fernando Antônio Novais. Prefácio: ao aluno. In: Aproximações, op.cit., pp. 331-332. O texto original é o prefácio ao livro de István Jancsó. Na Bahia contra o Império: história do ensaio de sedição de 1798. São Paulo: Hucitec, 1996, pp. 9-10.

${ }^{29}$ Para essa perspectiva de análise ler: Fernando Antônio Novais e Carlos Guilherme Mota. A Independência política do Brasil. São Paulo: Hucitec, 1996, 2ª . Edição.

${ }^{30}$ NOVAIS, op.cit., p. 13.

${ }^{31}$ István Jancsó. Na Bahia contra o Império - História do ensaio de sedição de 1798. São Paulo/Salvador: Hucitec/Edufba, 1996, p. 55.
} 
social, evidenciada na forma pela qual o governador da Bahia, d. Fernando José de Portugal e Castro, não só deixou "os membros da elite local, envolvidos na articulação sediciosa, à margem da suspeição e da repressão", como foi o responsável por restaurar-lhes a condição de súditos da Coroa. Ao ressaltar a emergência de novos padrões de sociabilidade política, na qual amplos setores interagiam entre si, o autor chama a atenção para o projeto esboçado pelos partícipes representar um grave risco para o reformismo português, pois as autoridades locais viram no conteúdo dos pasquins sediciosos a perda dos fundamentos tidos por necessários para a reiteração da sociedade colonial ${ }^{32}$.

A inflexão da análise do autor sobre o que é específico da Conjuração Baiana de 1798, o esboço de um projeto coletivo de homens de distinta condição social como o germe do novo, não esconde, contudo, um pressuposto implícito que é o constitutivo da análise de István Jancsó: o entendimento de 1798 via 1822. Ao conceber o evento como a expressão de categorias históricas cujo desenvolvimento projeta as contradições do presente em um futuro próximo, entrevendo sua própria superação, o autor necessariamente interpreta as manifestações do novo como um crescente processo de tomada de consciência ou mesmo de amadurecimento do fazer política em colônia com um fim específico: o longo processo de ruptura ${ }^{33}$.

Parece inegável que o que está subjacente à análise é a ideia de Crise do Sistema formulada por Fernando Antônio Novais que vê no esgotamento do capital mercantil como ordenador do real a emergência do capital industrial que, uma vez estruturado, é suficientemente forte para destruir suas próprias criaturas, as colônias, por exemplo, e instituir o novo como ordenador do real: a nação ${ }^{34}$. Esse também é o pressuposto da análise de Carlos Guilherme Mota sobre a Conjuração Baiana de 1798, em sua

\footnotetext{
${ }^{32}$ Idem, p. 206.

${ }^{33}$ Cf. István Jancsó. Bahia 1798: a hipótese de auxílio francês ou a cor dos gatos. In: Júnia Ferreira Furtado (Org.). Diálogos Oceânicos: Minas Gerais e as novas abordagens para uma história do Império Português. Belo Horizonte: Editora da UFMG, 2001, pp. 361-388. Ler a análise sobre o processo de Independência Política do Brasil em 1822 de Fernando Antônio Novais e Carlos Guilherme Mota in: $A$ Independência política do Brasil. São Paulo: Hucitec, 1996, 2a . edição, p. 12. Sobre o papel das revoltas ocorridas no final do século XVIII e início do XIX no processo de 1822, ler, especialmente, o capítulo 1 : O contexto, pp. 15-34.

${ }^{34}$ Cf. Rogério Forastieri da Silva. Colônia e Nativismo: a história como biografia da nação. São Paulo: Hucitec, 1997, p. 91. O autor problematiza a constituição do discurso histórico oitocentista sobre o passado colonial, especialmente sobre o objeto histórico global que é a "colônia". A colônia, segundo Forastieri, tem menos a ver com a nação do que com a expansão do capitalismo. Ao recolocar a colônia no Antigo Sistema Colonial, a independência é um longo processo de ruptura desencadeado pela crise do Antigo Sistema Colonial. Segundo o autor "é nesse processo que fica elidida a questão do movimento, da mudança, enfim, da própria história”.
} 
dissertação de mestrado, Ideia de revolução no Brasil (1789-1801), defendida em 1967, na cadeira de História Moderna e Contemporânea da Universidade de São Paulo.

Fundamentando-se nas proposições de Florestan Fernandes e de Lucien Goldmann, o autor interpreta o evento a partir das formas de pensamento como indicativas do processo de tomada de consciência articuladas à Crise do Antigo Sistema Colonial $^{35}$. O que lhe permite afirmar que o conceito de "propriedade se insinua de maneira significativa nos comportamentos e, não raro, nas tomadas de consciência dos seres coloniais ${ }^{, 36}$. De acordo com a análise a propriedade funciona como um divisor de águas, uma vez que ela é contraditória em situação colonial, deflagrando o que autor qualifica com cautela de "relações de litígio", já que não se trata de homens "neutros", mas sim de "contendores".

Para o autor, como a propriedade surge como uma entidade contraditória num sistema de colonização, ela é a base sobre a qual está assentada a sua própria dinâmica, "requisito e desintegrador do sistema", uma vez que o êxito da colonização depende do seu fortalecimento e desenvolvimento e, justamente por isso, acaba se opondo às metas do processo. A questão central da análise do autor é saber, em primeiro lugar, o "que é propriedade dentro de um sistema de colonização?”, para, em seguida, saber "que tipo de problemas e solução podem ser observados, e quais os encaminhamentos no nível da consciência possível da época?",37.

Carlos Guilherme Mota procura subsídios para responder a suas indagações na obra Recopilação de Notícias Soteropolitanas e Brasílicas ${ }^{38}$, escrita durante o período de 1797-1799, por Luís dos Santos Vilhena, professor-régio de língua grega considerado pelo autor a um só tempo "colono e colonizador, o que vale afirmar: a colonização em crise". Como para o autor as considerações de Vilhena permitem uma visão nítida das contradições dos grupos sociais e expressões próprias da Crise do Sistema Colonial, Carlos Guilherme Mota considera a obra "uma das melhores análises

\footnotetext{
${ }^{35}$ Carlos Guilherme Mota. Ideia de Revolução no Brasil (1789-1801). São Paulo: Ática, 1996, $4^{\mathrm{a}}$. edição. A primeira edição do livro foi publicada em Lisboa, em 1970, com o título de Ideias de inovação no Brasil. Lisboa: Livros Horizonte, 1970. A primeira edição brasileira data de 1979, acrescida de um apêndice com dois textos sobre a historiografia luso-brasileira e o problema das lutas de libertação nas excolônias portuguesas, com o título: Ideia de Revolução no Brasil (1789-1801). Campinas: Vozes, 1979. Cf. Prefácio à 4 Edição, op.cit., p. 7.

${ }^{36}$ Idem, p. 103.

${ }^{37}$ Idem, ibidem, p. 108.

${ }^{38}$ Luís dos Santos Vilhena. Recopilação de Notícias Soteropolitanas e Brasílicas. Salvador: Itapuã, 1969.
} 
da propriedade como base da nacionalidade, bem como da propriedade interferindo nas relações de homem a homem "39.

Cumpre destacar que, para o autor, o conceito de propriedade liga-se a outro conceito, passível de restrição ao se analisar a conjuntura da sociedade baiana de 1798: o de nacionalidade. Ao buscar em 1798 o rastilho do processo de independência política do Brasil em 1822, Carlos Guilherme Mota consegue encontrar nos escritos de Vilhena a nítida ideia de que "a concentração da propriedade da terra nas mãos de poucos representava não somente a viabilização de uma produção mercantil, mas também a

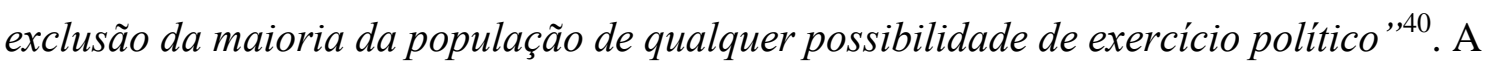
sistemática exclusão da participação da maioria da população nas estruturas internas do Estado, segundo o autor, fez com que aqueles homens de 1798 tomassem consciência da situação de crise em que viviam e buscassem a ordem perdida, manifestando-se pela via da contestação política.

Ao esclarecer que o conceito de nacionalidade liga-se ao conceito a-histórico que é o de propriedade, e esse, em Luís dos Santos Vilhena, refere-se necessariamente à posse da terra, Carlos Guilherme Mota deduz que "se por um lado a propriedade gera o sentimento de pátria, por outro o sentimento 'patriótico' surge como subversivo, na medida em que representa fratura no processo de colonização”. Não à toa, o autor encaminha a conclusão de seus argumentos, afirmando que os acontecimentos na Bahia de 1798 demonstram que o "sentimento patriótico, no Brasil do século XVIII, já significava revolução "41.

Foi a partir de conceitos muito próprios de propriedade, nacionalismo $e$ revolução que István Jancsó e Carlos Guilherme Mota, cada um a sua maneira, analisaram a Conjuração Baiana de 1798 nos quadros da Crise do Antigo Sistema Colonial. Nesse enquadramento geral do problema, a Independência é vista como um longo processo de ruptura ${ }^{42}$ que, examinado em si mesmo, insere-se na desagregação

\footnotetext{
${ }^{39}$ Mota, op.cit, p. 84.

${ }^{40}$ Florestan Fernandes. Circuito Fechado. São Paulo: Pioneira, 1976. Para uma visão da influência do autor nas proposições de Carlos Guilherme Mota, ler, especialmente, o capítulo 6: Propriedade, nacionalismo e revolução. pp. 105-125.

${ }^{41}$ Mota, op.cit., p. 115. Grifo meu.

${ }^{42}$ Em importante obra sobre o processo de emancipação política do Brasil, em 1822, Carlos Guilherme Mota e Fernando Antônio Novais afirmam que, entre a historiografia que versa sobre o tema, há duas proposições: uma que engloba todo o período de d. João VI no Brasil e estende o estudo até os limites do período regencial (1831-1840) e aquela que restringe os acontecimentos entre 1821 (volta de d. João para a Europa) e 1825 (tratado de reconhecimento). Os autores apresentam uma terceira via, segundo a qual se entende a "independência como um momento de um longo processo de ruptura, ou seja, a desagregação do Sistema Colonial e a montagem do Estado Nacional”. Nessa perspectiva, as revoltas mineiras de 1789
} 
do Sistema Colonial e na montagem do Estado nacional, e, no plano geral, na desagregação do Antigo Regime como um todo. A Conjuração Baiana de 1798, com efeito, passa a integrar a genealogia da Nação como um marco de referência popular $e$ ruptura da emancipação política do Brasil, em 1822.

Não se trata de afirmar que nas análises sobre a Conjuração Baiana de 1798 dos autores "a colônia contém a nação" e que o Estado e a Nação brasileiros são desaguadouros naturais da Colônia - questões que estão na base do discurso histórico da Primeira República, quando se considera o conjunto geral das revoltas do final do século XVIII e início do XIX. Ao contrário, pois para eles a história da colônia é integrada de modo sistêmico na economia-mundo, que na época de formação do capitalismo edificou uma história propriamente mundial ${ }^{43}$.

Nesse enquadramento do problema, a síntese da história da colônia seria o momento mesmo de sua emancipação, pois "trata-se de compreender a nação a partir da colônia e por oposição a ela, e indagar as possibilidades de transformação inscritas nesse processo" ${ }^{\text {44 }}$. Não parece ser à toa que nessa perspectiva de análise o processo de Independência invariavelmente levaria o Brasil do Antigo Sistema Colonial ao Sistema Mundial de Dependências - justificada em grande medida pelo caráter revolucionário atribuído ao movimento de 1822, em termos políticos, e conservador, em termos ideológicos ${ }^{45}$.

Todavia, na segunda metade do século XX em diante, a história tendeu a rejeitar a visão macroscópica e estrutural dos acontecimentos, até então dominante, em proveito de novas abordagens inspiradas pela antropologia, que privilegiam o indivíduo, o cotidiano, a narrativa e o acontecimento. A problemática apresentada por Kátia Mattoso $^{46}$ é a influência das ideias libertárias na Conjuração Baiana de 1798, em um

e a baiana de 1798 passariam a integrar a genealogia da nação como contradições do sistema, em manifestações da Crise do Antigo Sistema Colonial. Cf. Mota e Novais. A Independência política do Brasil. São Paulo: Hucitec, 1996, 2ª . edição, p. 12. Sobre a relevância das revoltas citadas no processo de 1822, ler, especialmente, o capítulo 1: $O$ contexto, pp. 15-34.

${ }^{43}$ Cf. Immanuel Wallerstein. O sistema mundial moderno. Porto: Afrontamento, 1974, 2 vols.

${ }^{44}$ Fernando Antônio Novais. Colonização e Sistema Colonial: discussão de conceitos e perspectiva histórica. In: Anais do IV Simpósio dos Professores Universitários de História, São Paulo, 1969, pp. 243268.

45 A base dessa análise constata o caráter contraditório da ideologia liberal do movimento de independência do Brasil: "Foi liberal porque suas lideranças viram-se obrigadas a mobilizar essa ideologia para justificar a separação com a metrópole. O aproveitamento dessa ideologia, entretanto, foi basicamente conservador, por terem que manter a escravidão e a dominação do senhoriato". In: Mota e Novais, op.cit., p. 83.

46 Kátia M. de Queirós Mattoso. Presença francesa do Movimento Democrático Baiano de 1798. Salvador: Itapuã, 1969; Bahia 1798: os panfletos revolucionários. Proposta de uma nova leitura. In: Da Revolução dos Alfaiates à riqueza dos baianos no século XIX. Salvador: Corrupio, 2004, pp. 317-330. 
momento em que a revolução se fazia concomitantemente na França. Após ressaltar o contexto da Bahia do final do século XVIII, um profundo mal estar social, no qual o movimento político não "logrou êxito", a autora demonstra os termos do projeto político elaborado pelos partícipes do evento, a partir da análise rigorosa dos pasquins sediciosos.

Para a autora, o projeto de revolta teve como protagonistas um grupo de homens livres inseridos nas camadas médias e baixas da sociedade urbana. Todavia, a autora chama a atenção para o fato de que, apesar da modesta situação, "esses homens representavam no conjunto da população de dominados categorias que, de certa forma, eram privilegiadas". Para Kátia Mattoso, "são estes homens soldados, ou então artesãos, que se encontram à frente do movimento”, cuja intenção foi propor uma aliança política com a elite local ${ }^{47}$. Dessa maneira, a autora demonstra que os argumentos dos pasquins sediciosos, por um lado, queriam sensibilizar a maior parte do público baiano com a "miragem da liberdade econômica", e, por outro, os partícipes procuraram também demonstrar que "uma eventual aquiescência ao seu projeto político, não contribuía para o abalo das estruturas profundas da sociedade ${ }^{, 48}$.

Luís Henrique Dias Tavares, por sua vez, aborda a complexidade dos fatos ocorridos em Salvador a partir das tensões e dos conflitos inerentes às relações de natureza funcional: como, por exemplo, oficial-soldado e senhor-escravo ${ }^{49}$. Isso porque para o historiador essas relações contribuíram para o aparecimento de pressupostos teóricos como instrumentos de uma ação política imediata. $\mathrm{O}$ autor situa a Conjuração Baiana de 1798 no quadro geral das revoluções democrático-burguesas, assim como Kátia Mattoso. Após a descrição de alguns documentos, nos quais o autor cita, inclusive, a comparação das letras dos pasquins com algumas petições dos milicianos, que se encontravam na Secretária de Estado e Governo do Brasil, Luís Henrique Tavares conclui que:

"fosse quem fosse o autor dos boletins, tudo indica que agiu por conta própria, tomando uma iniciativa que havia de precipitar numa possível ação o tudo de apenas conversas

Texto originalmente publicado em Osvaldo Coggiola (org.). A Revolução Francesa e seu impacto na América Latina. São Paulo: Edusp/Nova Stella, 1990, pp. 341-356.

${ }^{47}$ Cf. Kátia Mattoso, Bahia 1798..., op.cit., p. 344.

${ }^{48}$ Idem, p. 349.

${ }^{49}$ Luís Henrique Dias Tavares. História da sedição intentada na Bahia de 1798. São Paulo: Pioneira, 1975; As ideias dos revolucionários baianos. In: Arquivos da Universidade da Bahia, n. 04, Faculdade de Filosofia de Salvador, 1975; O Movimento Revolucionário Baiano 1798. Tese de Livre-docência na Faculdade de Filosofia da Universidade da Bahia; Da Sedição de 1798 à Revolta de 1824 na Bahia. Salvador/São Paulo: EDUFBA/UNESP, 2003. 
mulatos artesão e soldados, libertos, filhos e descendentes de escravos" 50 .

A afirmação do autor foi baseada no depoimento de um dos escravos presos, acusado de estar envolvido no movimento de 1798, Luís de França Pires, que contribuiu efetivamente com os Desembargadores do Tribunal da Relação da Bahia, denunciando todos os outros escravos de participação, inclusive do mesmo dono, José Pires de Carvalho e Albuquerque. Nesse depoimento o cativo afirma que os pasquins sediciosos "não podiam ser fabricados por algum dos facionários, porque os consideravam já esquecidos de semelhante lembrança; antes o atribuía a algum inimigo delles, que tivesse desejo de ver verificada a mesma revolução",51.

Nesse particular, cumpre destacar que entre os documentos citados, Luís Henrique Tavares, pela primeira vez, procura conceituar com cuidado os termos que os próprios agentes do movimento fizeram de "liberdade" e "revolução". No final do livro, após afirmar que a Conjuração Baiana de 1798 é um movimento político com duas etapas, o autor transcreve trechos de um diálogo entre dois dos réus enforcados e esquartejados na Praça da Piedade.

Luís Henrique Dias Tavares conclui, em 1969, que a Conjuração Baiana de 1798 significou

"a profunda contradição entre a velha ordem da exploração colonial mercantilista e a nova ordem capitalista, a luta dos brasileiros pela autonomia nacional, e o drama das discriminações em sociedade altamente comprometida pelo sistema de trabalho escravo" $" 52$.

Por ocasião das comemorações do II Centenário da Conjuração Baiana de 1798, tanto Luís Henrique Dias Tavares como István Jancsó recolocaram algumas questões acerca da composição social do evento ${ }^{53}$. Luís Henrique Dias Tavares parte dos resultados de pesquisas realizadas há alguns anos pela historiadora Kátia Mattoso, nos Arquivos Nacionais da França e da Marinha Francesa, e de novas direções apontadas no estudo da historiadora francesa Jeanine Potelet, que comprovaram que as "medidas tomadas para o socorro estrangeiro", segundo o $9^{\circ}$. "aviso ao clero e ao povo

\footnotetext{
${ }^{50}$ Cf. Luís Henrique Dias Tavares, História da sedição intentada, op.cit., p. 47.

51 Idem, ibidem.

52 Idem, ibidem.

${ }^{53}$ Ubiratan de Castro e Araújo, Luís Henrique Dias Tavares e outros. II Centenário da Sedição de 1798 na Bahia. Salvador/Brasília: Academia de Letras da Bahia/MINC, 1999.
} 
bahinense indouto", relacionam-se com a estada de um comandante francês na cidade de Salvador, um pouco antes de deflagrado o movimento ${ }^{54}$.

Segundo o autor, o comandante Larcher chegou ao porto de Salvador em 30 de novembro de 1796, obtendo autorização do então governador d. Fernando José de Portugal e Castro para que permanecesse na cidade por um mês - razão pela qual o autor questiona a presença do comandante Larcher na cidade de Salvador, em 1797, e a fundação da organização maçônica secreta em julho do mesmo ano, afirmada por Francisco Borges de Barros ${ }^{55}$. Primeiro, porque em um ofício de d. Fernando José de Portugal e Castro ao Ministro d. Rodrigo de Sousa Coutinho, o governador relata a partida do comandante Larcher em 2 de janeiro de $1797^{56}$. Depois, segundo o autor, Jeanine Potelet demonstra em seu "Projects d'expéditions et d'attaques sur les côtes $d u$ Brésil (1796-1800)" que, em 24 de agosto de 1797, o comandante Larcher informou ao Diretório, dispositivo supremo da República francesa, a boa recepção que encontrara na cidade de Salvador para com a Declaração dos Direitos do Homem, bem como a existência, entre os homens com os quais teve contato, da intenção de proclamar uma "república bahinense"

Diante disso, Larcher apresentou ao Diretório um ambicioso plano de ataque à Bahia, consistindo no envio de 4 navios, 3 fragatas e 2 barcas, 1500 homens de infantaria e 300 de artilharia ${ }^{58}$. Analisando o plano do comandante Larcher, o ponto alto da sua argumentação residia no enorme descontentamento econômico que identificou

\footnotetext{
${ }^{54}$ Cf. Aviso ao clero e ao povo bahinense indouto. In: Kátia M. de Queirós Mattoso. Presença francesa no Movimento Democrático Baiano de 1798. Salvador: Itapuã, 1969, p. 155. Durante muito tempo Kátia Mattoso foi considerada a autora da melhor transcrição dos pasquins sediciosos. No final de 2004, entretanto, Marcelo Moreira questiona a originalidade dos pasquins sediciosos que compõem o códice 581 do Arquivo Público do Estado da Bahia, reputados originais por alguns historiadores. O autor sugere que houve alteração dos pasquins originais pelo funcionário responsável pela cópia da documentação que compõe os Autos das devassas que, à época, estava na Secretaria de Estado e Governo do Brasil. Cf. Marcello Moreira. Litterae Adsunt: cultura escribal e os profissionais produtores do manuscrito sedicioso na Bahia do século XVIII, 1798. Politéia: Vitória da Conquista, vol. 4, 2004; Marcello Moreira. Apontamentos bibliográficos sobre os documentos relativos à Conspiração dos Alfaiates. Politéia, Vitória da Conquista, vol. 5, 2005.

${ }^{55}$ A ideia de uma organização secreta maçônica ter sido fundada em 14 de julho de 1797 aparece pela primeira vez no trabalho de Francisco Borges de Barros. Os confederados do partido da liberdade. Salvador: Imprensa Oficial do Estado, 1922. Chamamos atenção para o fato de que a fundação da agremiação foi durante muito tempo considerada a chave pela qual os especialistas poderiam verificar a participação de "homens de consideração" no evento.

${ }^{56} \mathrm{Cf}$. Algumas questões ainda não resolvidas na história da Sedição de 1798 na Bahia. In: Luís Henrique Dias Tavares. Da Sedição de 1798 à Revolta de 1824 na Bahia. Salvador/São Paulo: EDUFBA/UNESP, 2003, pp.27-54.

${ }^{57}$ Cf. Luís Henrique Dias Tavares, op.cit., p. 44; Jeanine Potelet. Projects d'expéditions et d'attaques sur les côtes du Brésil (1796-1800). In: L’Amérique Latine face a La Révolution Française. Caravelle. Cahiers Du Monde Hispanique et Luso-Brasilien, n. 54, pp. 209-222, Toulouse, 1990.

${ }^{58}$ Idem.
} 
entre os homens com os quais convivera durante sua estada em Salvador, em 1797.

Em seu último trabalho publicado, István Jancsó viu na argumentação de Larcher "um enorme sentimento antiabsolutista entre a parcela da elite com a qual convivera", 59 , desconsiderando a possibilidade de a ajuda francesa ao movimento baiano não ter ocorrido porque, como afirma Luís Henrique Dias Tavares, a França, à época, era uma metrópole que tentava de todas as formas conter as ações dos escravos em São Domingos para não perder uma de suas principais colônias.

Pode-se observar que os trabalhos de István Jancsó procuram comprovar uma maior abrangência social com a participação de homens brancos e proprietários na trama política ocorrida na Bahia de $1798^{60}$. Apesar de o autor criticar com veemência que a historiografia que versou sobre o evento, no século $\mathrm{XX}$, permaneceu presa ao grupo social circunscrito pelos desembargadores do Tribunal da Relação da Bahia em 1799, o autor também não escapou desse processo, pois sua hipótese contempla apenas a participação em reuniões de caráter sedicioso do padre Francisco Agostinho Gomes e da possível participação do cirurgião e proprietário de cinco escravos, Cipriano Barata, que estava longe de pertencer à elite soteropolitana da época ${ }^{61}$.

Além disso, em seus últimos trabalhos, Jancsó vale-se das atestações das autoridades soteropolitanas sobre a boa conduta do comandante francês na Bahia, afirmando ser "impensável a hipótese de Larcher ter confraternizado com pessoas de nível social tão distinto do seu, como o do soldado granadeiro [Luiz Gonzaga], tanto por limitações de língua quanto de valores" ${ }^{\prime 2}$. Parece inegável que as últimas análises de István Jancsó polemizam com a tese de Valentim Alexandre, para quem o evento ocorrido na cidade de Salvador de 1798 não passou de uma Inconfidência de:

"gente miúda, artesãos, soldados, na grande maioria mulatos, alguns escravos entre eles, cuja componente nacionalista é

\footnotetext{
${ }^{59}$ István Jancsó. Bahia 1798. A hipótese do auxílio francês ou a cor dos gatos. In: Júnia Ferreira Furtado (Org.). Diálogos Oceânicos: Minas Gerais e as novas abordagens para uma história do Império Ultramarino Português. Belo Horizonte: Editora UFMG, 2001, p. 370.

${ }^{60}$ Cumpre destacar que em seus primeiros trabalhos sobre a Conjuração Baiana de 1798, István Jancsó considerava Cipriano Barata e o professor Raimundo Moniz Barreto de Aragão como membros da elite baiana da época junto com o padre Francisco Agostinho Gomes - de fato de muitas posses. Em seus últimos trabalhos, no entanto, o autor incorporou a discussão historiográfica acerca do conceito de "elite" em territórios coloniais e passou a considerar apenas a presença do referido padre e de Joaquim Inácio de Siqueira Bulcão, proprietário de engenhos e fazendas de gado, como membros da elite baiana com evidências de participação na preparação do movimento. Ler: István Jancsó \& Marco Morel. Novas Perspectivas sobre a presença francesa na Bahia em torno de 1798. Rio de Janeiro, TOPOI, v. 8, n. 14, jan.-jun. 2007, pp. 206-232.

${ }^{61}$ Sobre a biografia de Cipriano Barata, ler: Marco Morel. Cipriano Barata na Sentinela da Liberdade. Salvador: Academia de Letras da Bahia/ Assembleia Legislativa da Bahia, 2001.

${ }^{62}$ Idem, p. 373.
} 
marginal, uma vez que não há, assim como em Minas de 1789, $o$ ataque ao ponto fundamental da dominação portuguesa: o exclusivo de comércio" $"$.

A partir do conceito de vulnerabilidade econômica pela qual o Império Português estava às voltas, Valentim Alexandre contrapõe-se à ideia de que as revoltas coloniais ocorridas no final do século XVIII indicavam que o império estivesse condenado à desintegração, pois para o autor, no caso da Bahia de 1798, a elite local se ausentou do processo, demonstrando a ausência de nacionalismo entre os partícipes do movimento. Evidentemente que Valentim Alexandre não polemiza com István Jancsó, mas com as teses de Fernando Antônio Novais para quem, como se viu, as revoltas coloniais seriam as agravantes no final do século XVIII do constante desenvolvimento do Sistema Colonial que desembocaria na sua própria superação com o peculiar processo de Independência Política do Brasil, deflagrado em 1822.

Seja como for, Valentim Alexandre não foi o único a reavaliar o papel das revoltas coloniais ocorridas no Brasil, final do século XVIII e início do XIX. No final dos anos setenta do século passado, Kenneth Maxwell analisou a Conjuração Baiana de 1798 em contraposição ao processo mineiro no que se refere à abrangência social. A minimização da complexidade do evento ocorre pela assertiva da ausência de racionalidade política dos partícipes. Para o historiador, tratou-se de ação política planejada, porém inconsistente, pois "muito antes de terem mesmo elaborado os planos mais rudimentares, os artesãos baianos foram apanhados", ficando visível às elites baianas a ameaça do evento cujas causas estavam na mistura de ressentimento social, alta dos gêneros alimentícios, impacto das palavras de ordem da Revolução Francesa e os exemplo das ações dos sans-culottes.

Maxwell é categórico ao afirmar que a inconsistência de racionalidade política da Conjuração Baiana de 1798 reside na ausência da elite local no movimento, protagonizado apenas por artesãos mulatos, soldados, "parceiros destituídos de propriedade" e professores "ressentidos e anticlericais". Não obstante a baixa composição social, o autor estende a tese da Inconfidência Mineira de 1789 como um "motim de acomodação", protagonizado pela "plutocracia local" da Capitania das Minas, para a Conjuração Baiana de 1798. A ideia do autor é que o Brasil do final do século XVIII era um ambiente propício para "motins de acomodação”, pois a seu ver:

\footnotetext{
${ }^{63}$ Cf. Valentim Alexandre. Os Sentidos do Império - Questão nacional e questão colonial na crise do Antigo Regime português. Porto: Ed. Afrontamento, 1993.
} 
"[...] o fracasso do movimento oligárquico de Minas Gerais, em 1789, e a ameaça subterrânea revelada pelo movimento dos alfaiates baianos de 1798 constituíram dois poderosos incentivos para uma acomodação com a metrópole. A atmosfera estava receptiva para reformas que evitassem o risco de um levante social. D. Rodrigo de Sousa Coutinho percebeu, com mais sensibilidade do que a maioria, as oportunidades que a situação oferecia e a necessidade de fazer ajustes inteligentes para evitar uma revolução destruidora" ${ }^{\text {64 }}$.

A sugestiva tese do autor acerca de as revoltas coloniais do final do século XVIII brasileiro representar "motins de acomodação" com a metrópole portuguesa nos leva a uma interrogação que o autor não resolveu em sua análise: que setor social envolvido na Conjuração Baiana de 1798 foi o protagonista do evento e, portanto, beneficiado pelo mecanismo de acomodação das forças políticas subjacentes àquela conflituosa conjuntura de fim de século na Bahia? Se a análise do autor confirma a circunscrição social do evento aos baixos setores daquela sociedade, de que maneira as elites baianas operaram a "acomodação" com a metrópole portuguesa se elas, segundo o autor, ausentaram-se o processo?

A ausência de respostas talvez esteja relacionada com o fato de a Conjuração Baiana de 1798 ocupar lugar marginal no conjunto geral de sua obra, muito provavelmente em razão da ausência de análise dos Autos das Devassas da Conjuração Baiana de $1798^{65}$. Apesar de não avançar em suas considerações acerca de as revoltas ocorridas no final do século XVIII significarem "motins de acomodação" e, portanto, oportunidade de a coroa portuguesa implantar reformas para evitar as revoluções, cumpre destacar que a análise do autor tocou em dois pontos nevrálgicos para os historiadores brasileiros que analisaram a dinâmica do processo de independência política brasileiro.

O primeiro deles é chamar a atenção para o impacto das propostas reformistas de d. Rodrigo de Sousa Coutinho em território colonial, após as consequências políticas e econômicas causadas pelas reformas pombalinas. Depois, o segundo ponto é o

\footnotetext{
${ }^{64}$ Kenneth Maxwell. A Devassa da Devassa. A Inconfidência Mineira: Brasil e Portugal 1750-1808. Rio de Janeiro: Paz \& Terra, 1999, p. 254.

${ }^{65}$ Chamo atenção para o fato de que nos depoimentos e nas acareações nos Autos das Devassas há várias informações acerca da participação de homens dos mais altos setores sociais da sociedade baiana da época em diversas reuniões na casa do Secretário de Estado José Pires de Carvalho e Albuquerque, bem como o nome dos proprietários dos escravos que depuseram durante as investigações, entre eles o próprio Secretário de Estado.
} 
liberalismo impulsionar tanto as revoluções quanto as reformas para evitá-las. Para isso, Maxwell valeu-se pela primeira vez da análise que Luís dos Santos Vilhena fez daquela conflituosa conjuntura de final de século e, especialmente, da Conjuração Baiana de 1798, que o professor régio qualificou de “insubsistente sublevação”, e que Maxwell entendeu ter sido causado pela alta de preços da carne e da farinha de mandioca ${ }^{66}$.

Apesar de ter o mérito de ter sido o único entre a historiografia da Conjuração Baiana de 1798 a citar a análise de Luís dos Santos Vilhena sobre a conflituosa conjuntura de fim de século, Kenneth Maxwell não levou adiante as considerações de Vilhena ao relacionar o evento de 1798 a duas questões importantes naquela conjuntura: o empréstimo à Real Fazenda por homens importantes da capitania da Bahia e a desordem da administração local durante o período de governação de d. Fernando José de Portugal e Castro, causada por um grupo que Vilhena qualifica de "corporação dos enteados", dado o caráter clientelístico de suas relações com o poder local e com a coroa portuguesa ${ }^{67}$.

Essas duas questões são o ponto de partida desta tese.

\section{3.}

\section{a tese, as fontes e a metodologia}

Em 8 de novembro de 1799, quatro homens foram enforcados e esquartejados na Praça da Piedade, na cidade de Salvador, por crime de lesa-majestade de primeira cabeça . Os alfaiates João de Deus do Nascimento e Manuel Faustino, e os soldados Lucas Dantas de Amorim Torres e Luiz Gonzaga das Virgens e Veiga foram mortos, porém não foram os únicos a participarem da Conjuração Baiana de 1798.

De acordo com a pesquisa de mestrado sobre o tema e com as informações nos Autos das Devassas, 39 pessoas foram presas para prestar esclarecimentos

\footnotetext{
${ }^{66}$ Idem, p. 244.

${ }^{67}$ Vilhena refere-se aos desmandos de um grupo que gravitava em torno da Junta da Real Fazendo. Notese que à época José Pires de Carvalho e Albuquerque era um dos Deputados. Cf. Luís dos Santos Vilhena. Recopilação de notícias soteropolitanas e brasílicas. Salvador: Itapuã, 1969, vol. 1, p. 138. Cumpre destacar que Luís dos Santos Vilhena qualificou a Conjuração Baiana de 1798 de "insubsistente sublevação" em razão da ausência de participação dos escravos, que significaria uma verdadeira ameaça de corrupção do tecido social. A esse respeito, ler, especialmente, o capítulo 2: Patrícia Valim. Da Sedição dos Mulatos à Conjuração Baiana de 1798: a construção de uma memória histórica. ”, op.cit.
} 
circunstanciados a respeito do levante armado que se projetara na Salvador de 1798, dentre as quais dez escravos domésticos. Concluídas as investigações, alguns escravos foram condenados à pena de degredo. Outros tentaram fugir assim que perceberam o que se avizinharia com o fim das investigações. Outros, ainda, além de merecer justificação no decorrer das devassas, foram inocentados de qualquer culpa no crime de sedição ${ }^{68}$.

Uma das razões para as várias penas imputadas aos cativos está intimamente relacionada com uma questão até o momento tangenciada pela historiografia que versou sobre o evento: os proprietários desses escravos e suas relações com o poder local. A questão adquire complexidade se considerarmos as informações fornecidas na principal documentação sobre a Conjuração Baiana de 1798 há muito analisada. De acordo com os Autos das Devassas, os escravos foram indiciados na devassa aberta pelo desembargador do Tribunal da Relação, Francisco Sabino Álvares da Costa Pinto, para verificar os "fatos conexos" aos "pasquins sediciosos", divulgados na manhã do dia 12 de agosto de 1798. O modo pelo qual o desembargador chegou à participação dos escravos é bastante significativo e, conforme a expressão de um dos proprietários, fez-se "pronta entrega dos escravos"69.

No dia 7 de setembro de 1798, Francisco Vicente Viana, homem branco, Ouvidor da Bahia, Juiz dos Órfãos e Ausentes, proprietário dos Engenhos Madruga Cedo, Paramerim e Monte, todos localizados no distrito da Vila de São Francisco do Sergipe do Conde, formulou culpa sobre a participação de Luiz Gonzaga das Virgens na "projectada revolução",70. Em seu testemunho, após isentar seu escravo de qualquer participação mais efetiva na reunião do dia 25 de agosto no Campo do Dique do Desterro, afirmou que soube:

“[...] pela voz pública sabe que se tentava fazer hum levantamento nesta Cidade [Salvador] com saque, e assassino com effeito de se estabelecer nella hum Governo Democrático, livre e independente; de cujo artefacto são os authores huns poucos mulatos em que tinhão a primeira parte Luiz Gonzaga das Virgens [...] ${ }^{, 71}$.

\footnotetext{
${ }^{68}$ Sobre os escravos da Conjuração Baiana de 1798, ler: Luís Henrique Dias Tavares. Os escravos na Sedição de 1798 na Bahia. In: Da Sedição de 1798 à Revolta de 1824 na Bahia. São Paulo/Salvador: Editora Unesp/EDUFBA, 2003, pp. 89-124. Sobre a variação da pena imputada aos escravos da Conjuração Baiana de 1798: Patrícia Valim, op.cit., ler, especialmente o Capítulo 1.

${ }^{69}$ ADCA, vol. II, p. 925, Testemunho de Manoel Vilella de Carvalho, proprietário do escravo José Felix da Costa.

${ }^{70}$ Cf. "Testemunhas da devassa...". Ler, especialmente o depoimento da testemunha n. 6, Francisco Vicente Viana, ADCA, vol. 2, pp. 923-924.

${ }^{71}$ Idem.
} 
Francisco Vicente Viana terminou seu testemunho afirmando que o tal "fuão"72, Luiz Gonzaga das Virgens, era de "hum carather insolente, e dezavergonhado, bem capaz de entrar nesta diabólica empreza [revolta]". No mesmo dia, foi chamado a formular culpa outro senhor de escravo, Manoel José Villela de Carvalho, homem branco, solteiro, Tesoureiro da Real Fazenda, negociante de grosso trato e proprietário do Engenho Marapé, em São Francisco da Barra de Sergipe do Conde. Seguindo o padrão do testemunho de Francisco Vicente Viana, Manoel José Vilela de Carvalho afirmou ao desembargador Costa Pinto que sabia:

"por ouvir dizer constante e notoriamente que se projectava fazer hum Levante nesta Cidade com saque e assassinos para se estabellecer hum Governo Democrático, livre e independente, $e$ que os authores desta empreza forão huns poucos de mulatos e enimozos, entre os quais forão os primeiros Luiz Gonzaga das Virgens, [...] que dizem espalhara pouco antes huns papéis sediciozos e libertinos, pelos Lugares Públicos e mais Sagrados ${ }^{, 73}$.

Manoel José Vilela de Carvalho terminou sua denúncia afirmando ao desembargador que para não constar qualquer dúvida sobre a participação de seus escravos no movimento, delatou tudo o que sabia ao "Illustríssimo e Excellentíssimo Governador, fazendo pronta-entrega dos escravos "74. A informação é corroborada pelo autor anônimo da "Relação de Francesia formada pelos homens pardos na cidade da Bahia no ano de $1798^{\text {"75, }}$, cujo teor afirma que alguns senhores entregaram seus escravos à justiça porque estavam temerosos de serem acusados de conivência em ações "sediciosas", e de "ausência de limpeza de mãos" à frente dos órgãos que ocupavam na administração da Capitania da Bahia.

Se aceitarmos o argumento do autor anônimo em sua "Relação", o episódio "pronta entrega de escravos" remete-nos à ponta inversa que a condição legal de "escravo" designava naquela sociedade: seus proprietários e suas atuações no poder local. Um exame detalhado da documentação demonstra que os proprietários dos

\footnotetext{
${ }^{72}$ Nos depoimentos de Francisco Vicente Viana e de Manoel José Villela de Carvalho, ambos senhores de escravos, é frequente o termo "fuão", para designar "fujão", referente aos réus pardos acusados de crime de lesa-majestade.

${ }^{73}$ ADCA, vol. II, p. 925, Testemunho de Manoel Vilella de Carvalho, proprietário do escravo José Felix da Costa.

${ }^{74}$ Idem.

${ }^{75}$ Arquivo do Instituto Histórico e Geográfico Brasileiro, doravante IHGB, ; Relação de francesia formada pelos homens pardos da cidade do Salvador, in: Descripção da Bahia, Tomo IV, DL, 399.2, pp. 294-301.
} 
escravos entregues à justiça formavam um grupo homogêneo, pequeno e composto pelos donos das maiores fortunas da Salvador de 1798. Homens de muita "opulência e luzimento", o grupo era assim constituído:

- José Pires de Carvalho e Albuquerque: Secretário de Estado e Governo do Brasil; Intendente da Marinha e Armazéns Reais; Deputado da Junta da Real Fazenda; Vedor Geral do Exército; Provedor e Ouvidor da Alfândega da Bahia; Irmão-maior da Santa Casa de Misericórdia; casado com d. Ana Maria de São José e Aragão, herdeira do morgado dos Garcia D’Ávila. Proprietário do Solar do Unhão, dono de nove engenhos junto com seu cunhado, Inácio de Siqueira Bulcão, e proprietário do Morgado de sua família. Um dos principais credores da Real Fazenda e o terceiro maior senhor de engenho devedor da Bahia. Professo na Ordem de Cristo. Natural da Bahia ${ }^{76}$;

- Bernardino de Sena e Araújo: Cursou a Universidade de Coimbra. Tabelião e Escrivão do Público Judicial e Notas da Bahia. Professo na Ordem de Cristo. Natural da Bahia ${ }^{77}$;

- Francisco Vicente Viana: Bacharel pela Universidade de Coimbra. Juiz dos Órfãos e Ouvidor da Bahia da parte do Norte. Futuro Barão do Rio das Contas e Presidente da Província da Bahia (1823-1824). Casado com Emília Augusta Moniz Bulcão, filha de José Moniz Barreto de Aragão, Barão de Itapororocas. Sócio do negociante e traficante de escravos Inocêncio José da Costa na arrematação dos contratos dos dízimos. Proprietário dos engenhos Madruga Cedo, Paramerim e Monte. Natural de Lisboa ${ }^{78}$;

- Caetano Maurício Machado: Professo na Ordem de Cristo, Sargento-mor do Regimento de Infantaria Auxiliar. Ajudante de Ordens do Governo da Capitania da Bahia. Negociante e sócio proprietário de algumas embarcações que traficavam escravos. Casado com d. Caetana Joaquina de Fonseca Machado, que em 1807 aparece como proprietária dos engenhos Mombaça e Campo. Natural de Lisboa $^{79}$;

- Manoel José Villela de Carvalho: Negociante e um dos arrematadores dos contratos do dízimo. Tesoureiro das adições da Administração da Real Fazenda da Bahia. Sócio proprietário de embarcações do tráfico de escravos. Natural do $\underline{\text { Porto }}^{80}$;

\footnotetext{
${ }^{76}$ AHU_CU_CA_Baía, Cx. 210, doc. 14878: Attestação de d. Rodrigo José de Menezes, 03 de janeiro de 1788.

${ }^{77}$ AHU_CU_CA_Baía, Cx. 79, docs. 15268-15269.

${ }^{78}$ Arquivo Histórico Theodoro Sampaio, do Instituto Geográfico e Histórico da Bahia, doravante AHTS/IGHBa, Caixa 001: Decreto de nomeação do bacharel Francisco Vicente Viana.

${ }^{79}$ AHU_CU_CA_Baía, Cx. 81, doc. 15698. Autos da devassa de Residência do Desembargador da Relação da Bahia, José Theotônio Sedron Zuzarte.

${ }^{80}$ Idem. No início de 1799 , d. Fernando recebeu o relato de uma representação feita na Corte, cujo teor
} 
- Joaquim Pereira Bastos: Irmão do Ouvidor das Ilhas de São Tomé e Príncipe Antônio Pereira Bastos (Lima Varella Barca). Serventuário de um dos Ofícios de Escrivão da Ouvidoria Geral do Cível da Bahia, nomeado em 15 de maio de 1799. Tudo leva a crer que era natural de Lisboa ${ }^{81}$;

- Paulino de Sá Tourinho: Capitão de Milícias da Capitania da Bahia. Irmão Maior da Santa Casa de Misericórdia da Bahia. Casado com Teodora Maria do Sacramento. Natural da Bahia ${ }^{82}$;

- Maria Francisca da Conceicão e Aragão: Cunhada do Secretário de Estado José Pires de Carvalho e Albuquerque e avó de sua esposa, d. Anna Maria de São José e Aragão. Proprietária dos engenhos Cazumba e Grama, e de algumas fazendas de gado. Natural da Bahia ${ }^{83}$.

Como se pode observar na relação dos proprietários dos escravos entregues à justiça durante a investigação da Conjuração Baiana de 1798, à exceção de Maria Francisca da Conceição, quase todos os homens eram habilitados na Ordem de Cristo ${ }^{84}$, e a maioria deles exercia um ou mais postos estratégicos da administração régia ${ }^{85}$. Assim, considerando-se a relevância política e econômica do grupo de proprietários dos escravos na Bahia do final do século XVIII, caberia saber as razões pelas quais esse grupo de notáveis ${ }^{86}$, qualificado por Vilhena de corporação dos enteados, fez "pronta-

referia-se ao atraso de pagamentos dos professores régios da Bahia. A queixa recaía sobre o tesoureiro dos ordenados, Manoel José Villela de Carvalho, um dos proprietários dos escravos indiciados nas devassas da Conjuração Baiana de 1798 e suspeito de fazer mau uso da verba pública. Biblioteca Nacional, doravante BN, sessão de manuscritos, fundo Marquês de Aguiar, doc. № 140 .

${ }^{81}$ APEB, Livro de Provisões Régias, №. 305 (1797-1801) folhas: 103, 103v.

${ }^{82}$ ANTT, Registro Geral de Mercês, d. Maria I, Livro 29, Folha 88; ANTT, Registro de Certidões, Livro 1 , folha 296.

${ }^{83}$ AHU_CU_CA_Baía, Cx. 88, doc. 17264

${ }^{84}$ Arquivo Nacional da Torre do Tombo, doravante ANTT, Códice Habilitação da Ordem de Cristo: José Pires de Carvalho e Albuquerque, filho de outro do mesmo nome, e de D. Isabel Joaquina de Aragão. De 19 de maio de 1779. Habilitação da Ordem de Cristo. Letra J, Maço 49, número 5; Bernardino de Sena e Araújo. Habilitação da Ordem de Cristo, Letra B, Maço 9, número 1; Caetano Maurício Machado. Habilitação da Ordem de Cristo, Letra C, Maço 8, número 3; Manoel José Vilela de Carvalho. Habilitação da Ordem de Cristo, Letra M, Maço 37, número 8; Manoel José Vilela de Carvalho. Habilitação da Ordem de Cristo, Letra M, Maço 29, número 42.

${ }^{85}$ Para uma visão de conjunto sobre as famílias dos proprietários de escravos da Conjuração Baiana de 1798, ler: Catálogo genealógico das principais famílias que precederam de Albuquerques e Cavalcantes em Pernanbuco e Caramurus na Bahia. Segundo Moniz Bandeira, essa obra foi escrita por volta de 1768 e publicada pelo Instituto Histórico e Geográfico Brasileiro em 1889. A reedição em dois volumes que data de 1985 foi acrescida por uma introdução e notas de Pedro Calmon, op.cit; Antônio de Araújo de Aragão Bulcão Sobrinho. O patriarca da liberdade bahiana: Joaquim Inácio de Siqueira Bulcão, $1^{\circ}$. Barão de São Francisco. Bahia, 1946. Antônio de Araújo de Aragão Bulcão Sobrinho. Famílias Bahianas (Bulcão, Pires de Carvalho e Vicente Viana), vol. 1, Bahia: Imprensa Oficial, 1945.

${ }^{86}$ Chamo atenção para o fato de que a qualificação do grupo de proprietários que entregou seus escravos à justiça, em 1798, de Notáveis refere-se ao papel desempenhado pela nobreza na Assembleia dos Notáveis na França de 1787 e imediatamente depois, ao encetar revoltas com o objetivo de restabelecer sua preponderância política e salvaguardar seus privilégios sociais. Sobre a Assembleia dos Notáveis ler: Albert Soboul. A Revolução Francesa. Rio de Janeiro: Difel, 2007, 9ª Edição, pp. 13-15. 
entrega" de seus escravos à justiça, durante as investigações da Conjuração Baiana de 1798.

A partir de uma enorme quantidade de fontes dos mais variados matizes e pulverizadas em diversos arquivos brasileiros e portugueses, pôde-se constatar, como se terá oportunidade de demonstrar, que o grupo de notáveis envolveu-se na maioria dos conflitos da Bahia do final do século XVIII, sendo que alguns desses proprietários e seus familiares também aparecem direta ou indiretamente envolvidos nos conflitos em outras localidades do Império Português, sob jurisdição da Capitania da Bahia, como as Ilhas de São Tomé e Príncipe, por exemplo. Constatou-se mais: não obstante a comprovação de envolvimento em ações qualificadas como ilícitas pelas autoridades régias, como a prática de contrabando, ausência de limpeza de mãos e favorecimento político e econômico entre eles, o governador-general da capitania da Bahia, d. Fernando José de Portugal e Castro (1788-1801), tomou uma série de medidas para garantir e ampliar suas privilegiadas condições econômica e política, contando com a aprovação régia.

Tais constatações refinaram a elaboração do problema desta tese: se durante o período do governo de d. Fernando José de Portugal e Castro na capitania da Bahia, 1788-1801, esse grupo de notáveis contou com o apoio do governador e com o Real Ânimo, por que ainda assim eles fizeram "pronta-entrega" de seus escravos à justiça em 1798? Além disso, por que o governador-general da capitania da Bahia, d. Fernando José de Portugal e Castro, apoiava-os constantemente em detrimento de outros setores importantes da sociedade soteropolitana da época, valendo-lhe várias repreendas de $\mathrm{d}$. Rodrigo de Souza Coutinho e a desqualificação de "frouxo", por alguns contemporâneos, no que se referia à condução dos interesses metropolitanos na Bahia?

A pesquisa bibliográfica somada à análise documental demonstrou que tais questões relacionam-se à necessidade de se analisar a Conjuração Baiana de 1798 a partir do enquadramento geral do problema que são as dinâmicas políticas e econômicas pelas quais o Império Português estava às voltas no final do século XVIII. Tal perspectiva de análise, a Conjuração Baiana de 1798 a partir do Império Português, e vice-versa, demonstrou que a alardeada e aparente "frouxidão" de d. Fernando José de Portugal e Castro encobria seu alinhamento político em oposição às propostas reformistas de d. Rodrigo de Sousa Coutinho, preservando os interesses da corporação dos enteados, cujo pragmatismo no modo de governar as demandas metropolitanas e os conflitos da Capitania da Bahia e nas Ilhas de São Tomé e Príncipe agradaram cada vez 
mais o Real Ânimo. Características que, ao fim e ao cabo, foram determinantes para a influente carreira de d. Fernando José de Portugal e Castro na Corte Joanina, após 1801.

Como se terá oportunidade de demonstrar, o pragmatismo do governador da Capitania da Bahia fazia parte de um projeto político que começou a ser alinhavado no final de 1796, envolvendo o grupo de notáveis que entregou seus escravos aos desembargadores responsáveis pelas investigações da Conjuração Baiana de 1798. O que se percebe é que na conflituosa conjuntura do final do século XVIII, o projeto político do grupo de d. Fernando José de Portugal e Castro passou a coexistir em oposição ao projeto político do grupo de d. Rodrigo de Sousa Coutinho, que assumiu a Secretaria da Marinha e Domínios Ultramarinos em 1796, e tinha como principal objetivo o recrudescimento político para a dinamização das finanças régias, assente em dois princípios: a unidade política e a dependência econômica ${ }^{87}$.

A documentação demonstra que com a fragilidade da regência de d. João $\mathrm{VI}^{88} \mathrm{e}$ do Império Português nos conflitos entre as nações europeias, as propostas reformistas de d. Rodrigo de Souza Coutinho passaram a ser cada vez mais contestadas na Bahia, sobretudo depois de propor uma série de medidas que contrariavam os interesses políticos e econômicos do grupo de notáveis que foram adquirindo proeminência econômica e política na Capitania a partir das brechas abertas pelas reformas pombalinas. O fato é que a oposição às reformas de d. Rodrigo de Sousa Coutinho na Bahia de 1798, explicita as clivagens políticas das elites governativas no interior do próprio Império Português e suas conexões ultramarinas, com o grupo ligado ao Secretário de Estado José de Seabra da Silva, que, em 1799, temia que formalização da regência de d. João VI conferisse maior poder a d. Rodrigo de Sousa Coutinho ${ }^{89}$.

Em um importante texto datado de 30 de março de 1800, no qual Domingos Vandelli confrontou os argumentos a favor e contra a celebração de um Tratado de Paz com a França, tais clivagens foram qualificadas como "partidos": pequenos agrupamentos informais e instáveis, que se constituíam em função da distribuição de cargos do governo ${ }^{90}$. Durante o período de 1796-1801, Vandelli cita a existência de dois

\footnotetext{
${ }^{87}$ Cf. Andrée Mansuy Diniz Silva. Portrait d'um homme d'État: $d$. Rodrigo de Souza Coutinho, Comte de Linhares (1755-1812). Paris: Centre Culturel Calouste Gulbenkian, 2006; José Luís Cardoso. Nas malhas do Império: a economia política e a política colonial de $d$. Rodrigo de Souza Coutinho. In: José Luís Cardoso (Org.) A economia política e os dilemas do império luso-brasileiro (1790-1822). Lisboa: Comissão Nacional para as Comemorações do Descobrimento Portugueses, 2001, pp. 65-109.

${ }^{88}$ Cf. Jorge Pedreira e Fernando Dores Costa, op.cit., p. 83 e segs.

${ }^{89}$ Idem, p. 85.

${ }^{90}$ BN, códice 9909, fls 311-318. Domingos Vandelli. Problema: se actualmente convém aceitar ou rejeitar a Paz.
} 
"partidos": os pró-franceses, também chamados de "pombalinos", com Antônio de Araújo Braga, depois Conde da Barca, aliado político de d. Fernando José de Portugal e Castro, e os prós-ingleses, com d. Rodrigo de Sousa Coutinho ${ }^{91}$.

No entanto, ao analisar os antecedentes da assinatura do Tratado de Paz, em agosto de 1797, logo depois anulado, Joaquim Pintassilgo desmistifica a qualificação de "afrancesado" do grupo de Antônio de Araújo Braga, demonstrando que a principal agenda política desse grupo não estava relacionada à França revolucionária, mas à tradicional posição de neutralidade da Diplomacia Portuguesa nos conflitos entre as nações europeias ${ }^{92}$. A anulação do Tratado de Paz de 1797 com a França e a mudança no alinhamento político da Espanha obrigou a diplomacia portuguesa a alterar sua posição no quadro europeu. Durante o período de 1797-1800, a coroa portuguesa deixou de pertencer à esfera da influência britânica e ficou sob constante pressão da França.

Ao desmitificar a qualificação de "afrancesado" do grupo ao qual o governador da Bahia estava alinhado na metrópole, Pintassilgo sugere o questionamento sobre os acontecimentos na França revolucionária e as palavras de ordem da Revolução como importantes mecanismos de negociação da política metropolitana e local, especialmente se considerarmos os termos veiculados pelos boletins manuscritos, afixados em prédios públicos na manhã de 12 de agosto de 1798, que deflagraram o movimento e explicitaram as demandas políticas e econômicas de seus partícipes.

Nessa perspectiva de análise, parece inegável que essa conflituosa conjuntura interna e externa do Império Português, tenha sido capitalizada pelo grupo de notáveis e pelos partícipes da Conjuração Baiana de 1798, que explicitaram uma dura crítica à legitimidade da regência de d. João VI:

"O vos homens Cidadaons, o vos Povos curvados $e$ abandonados pelo Rei, pelos seus dispotismos, pelos seus ministros ... O vos Povo que nascesteis para sereis livres e para gozares dos bons efeitos da Liberdade, o vos Povos que viveis flagelados com o pleno poder do Indigno coroado esse mesmo rei que vos creasteis; esse mesmo rei tirano he quem se firma no trono para vos veixar, para vos roubar e para vos maltratar $^{93, "}$

\footnotetext{
${ }^{91}$ Idem, grifo meu.

92 Joaquim Pintassilgo. Diplomacia Política e Econômica na transição do século XVIII para o século XIX: o pensamento e a acção de Antônio de Araújo de Azevedo (Conde da Barca). Dissertação de Mestrado em História apresentada à Faculdade de Ciências Sociais e Humanas da Universidade Nova de Lisboa, Lisboa, 1987, pp. 152-190.

${ }^{93}$ Apud Kátia M. de Queirós Mattoso. Presença Francesa no Movimento Democrático Baiano de 1798. Salvador: Itapuã, 1969, p. 149.
} 
Além disso, cumpre destacar que alguns dos proprietários dos escravos entregues por ocasião da Conjuração Baiana de 1798 foram vereadores e procuradores da Câmara de Salvador até $1795^{94}$. A partir de 1796, houve uma mudança de grupo que ocupou os cargos da Câmara que, de acordo com análise da documentação intitulada "posturas da Câmara de Salvador", esteve muito mais afinado com as reformas de d. Rodrigo de Sousa Coutinho, especialmente no que se referia ao fim dos contratos serem arrematados em leilão e passarem para a real fazenda da Bahia e ao aumento dos tributos sobre a quantidade de gêneros tributáveis e não sobre os preços.

O posicionamento da Câmara a favor das propostas de d. Rodrigo de Sousa Coutinho, a partir de 1796, não foi por acaso: tais propostas prejudicariam muito os interesses econômicos dos proprietários dos escravos de 1798, pois alguns deles formavam o grupo que arrecadavam os dízimos da Bahia e também comerciavam os produtos que passariam a ser tributáveis. Além disso, apesar das mudanças previstas para a arrecadação dos dízimos nas reformas de d. Rodrigo de Sousa Coutinho, a própria coroa portuguesa prorrogou por decreto a arrematação do contrato da Bahia, três anos antes do vencimento, para um grupo de negociantes portugueses que controlava esse contrato na capitania de São Paulo e Pernambuco.

As implicações desse processo foram muitas, como se terá oportunidade de demonstrar, por ora cumpre destacar que o recrudescimento do pacto colonial e as reformas propostas por d. Rodrigo de Sousa Coutinho, no final do século XVIII, desencadearam, paradoxalmente, uma tomada de consciência da exploração colonial fazendo com que os altos setores da capitania da Bahia reivindicassem suas participações em vários negócios régios, entre eles a possibilidade de arrematação do dízimo, internalizando seus interesses. Tratá-los como "enteados" nas estruturas econômicas e políticas do Império Português, excluindo-os da arrematação do contrato do dízimo em benefício dos negociantes portugueses, alterar as regras para a arrematação dos ofícios de Fazenda e Justiça - cargos ocupados pelos homens da corporação dos enteados -, findar a instituição dos morgados e recrudescer a repressão no comércio ilegal configuram-se em razões verossímeis para que esses homens estabelecessem uma aliança programática com o contingente armado da capitania da

\footnotetext{
${ }^{94}$ Affonso Ruy. História da Câmara Municipal da Cidade de Salvador. Salvador: Câmara Municipal de Salvador, 2002, 3ª Edição aumentada. Ler, especialmente, Capítulo XIX "Relação Geral dos Juízes Ordinários, Vereadores, Procuradores, Intendentes e Prefeitos Eleitos ou Nomeados para a Câmara do Município de Salvador, de 1549 a 1951”, pp. 333-379.
} 
Bahia, os milicianos, e elaborassem demandas políticas e econômicas explicitadas nos boletins manuscritos.

$\mathrm{O}$ argumento adquire complexidade quando se considera que alguns homens da Capitania da Bahia, animados pelo espírito crítico da época, escreveram relações circunstanciadas acerca das condições econômicas e políticas da Bahia, como denunciaram cada vez mais os desmandos do grupo de notáveis à frente de órgãos estratégicos da administração local em razão do que eles qualificaram na maioria das relações, cartas e relatórios enviados à Coroa de "frouxidão" do governador da Bahia, d. Fernando José de Portugal e Castro. São os casos, por exemplo, de Luís dos Santos Vilhena e José Venâncio de Seixas, que mesmo prospectando ascensão social com seus escritos, no final das contas, denunciaram a relação promíscua que esse grupo de notáveis mantinha com a esfera de poder local para benefício e enriquecimento próprio, e, aos olhos desses contemporâneos, em prejuízo do Real Erário e felicidade dos povos.

Tais denúncias deflagraram tensões e conflitos entre grupos locais e entre dois importantes quadros da política metropolitana: d. Fernando José de Portugal e Castro e d. Rodrigo de Sousa Coutinho ${ }^{95}$. Tensões suficientemente agravadas quando d. Rodrigo de Sousa Coutinho percebeu que suas reformas não só contrariavam os interesses da corporação dos enteados, que também foram alguns dos principais colaboradores da coroa portuguesa na capitania da Bahia - como o próprio Secretário de Estado e Governo do Brasil, José Pires de Carvalho e Albuquerque, além de ter sido o maior senhor de engenho credor da Coroa Portuguesa por ocasião dos empréstimos reais abertos por editais públicos no final do século XVIII, foi um dos grandes articuladores políticos da capitania da Bahia no período.

A privilegiada posição política e econômica do Secretário de Estado e Governo do Brasil, José Pires de Carvalho e Albuquerque, o principal personagem desta tese, explica muito as posturas tidas por contemporizadoras e "frouxas" de d. Fernando José de Portugal e Castro e da própria coroa portuguesa em relação às atuações pouco ortodoxas da corporação dos enteados no aquém e no além-mar. Tudo leva a crer que a "contemporização" do governador da capitania da Bahia com esse grupo de notáveis não só agradou como foi incentivada pelo Real Ânimo na figura do príncipe regente d. João VI, que passou a considerar d. Fernando José de Portugal e Castro como um dos seus principais colaboradores a partir de 1799, com a resolução definitiva de vários

\footnotetext{
${ }^{95}$ Patrícia Valim, op.cit.,ler, especialmente, o Capítulo 2.
} 
conflitos, entre eles a Conjuração Baiana de 1798 e o episódio nas ilhas de São Tomé e Príncipe.

A tese desta pesquisa de doutoramento, portanto, é: a Conjuração Baiana de 1798 como um movimento político de contestação que envolveu pessoas de distinta condição social como: milicianos e um grupo de notáveis formado por homens ricos e membros da administração local, cada qual com projetos políticos definidos, embora conflitantes em seus termos. Não obstante a contradição das demandas políticas dos grupos envolvidos percebe-se que foi na primeira fase do movimento que os partícipes elaboraram uma prática política coletiva que fragilizou os pressupostos tidos por necessários para a reiteração do poder metropolitano na Bahia.

A primeira fase, 1796-1798, é quando d. Rodrigo de Sousa Coutinho assumiu o Ministério da Marinha e do Ultramar e prospectou a implantação de reformas que dinamizassem a economia do Império Português, recrudescendo, sobretudo, a relativa autonomia e projeção política e econômica do grupo de notáveis que estavam ligados, de alguma maneira, ao controle da produção para exportação e para o abastecimento, e ocupavam estratégicos cargos na administração local. Foi a partir de 1796 que o movimento político começou a ser esboçado com uma composição social mais ampla, cujas pessoas participavam de reuniões ocorridas na casa do Secretário de Estado e Governo do Brasil, José Pires de Carvalho e Albuquerque, onde se discutiam questões externas e internas da capitania da Bahia e do Império Português.

A segunda fase, 1798-1800, é caracterizada pela deflagração do movimento quando, na manhã de 12 de agosto de 1798, boletins manuscritos foram afixados em locais públicos da cidade de Salvador, explicitando as demandas políticas e econômicas dos partícipes e convocando a população a participar do movimento que instituiria a “República Democrática Bahinense”. À deflagração do movimento, seguiram-se as devassas abertas a mando do governador-general para se descobrir "os cabeças" e os partícipes do movimento. No final das investigações, a resposta do poder local ao desafio imposto ficou circunscrita aos mais baixos setores da sociedade baiana da época, indicando que os desembargadores do Tribunal da Relação da Bahia desconsideraram o teor dos depoimentos sobre a participação da corporação dos enteados à margem das investigações. Foi nessa fase que a coroa portuguesa empreendeu uma série de soluções de compromisso com o grupo, afastando-lhes a condição de "enteados" das dinâmicas políticas e econômicas do Império Português e conferindo-lhes a condição de "súditos". 
Para que os objetivos desta tese fossem efetivados, além dos Autos das Devassas e da documentação do projeto Resgate, especialmente os Avulsos da Bahia de Castro e Almeida e Luiza da Fonseca, analisou-se uma série de documentos pulverizados em arquivos brasileiros e portugueses, até então pouco cotejados nas análises sobre a Conjuração Baiana de 1798. Trata-se de livros de Provisões Régias, Ordens Régias, Portarias, Cartas das autoridades locais e metropolitanas, Pareceres e Posturas da Câmara Municipal e Balanços de Importação e Exportação da Capitania da Bahia, durante o período de 1796-1800 - documentos que contemplam as ações do grupo de notáveis, do governador d. Fernando José de Portugal e Castro e da metrópole portuguesa $^{96}$. Para análise da atuação do grupo de notáveis na Capitania da Bahia, durante o período de 1796-1800, a investigação prosopográfica auxiliou na reconstituição das características comuns desse grupo por meios de suas biografias coletivas $^{97}$.

Além disso, esta tese se inspira, sobretudo, nos estudos historiográficos que chamam atenção para as implicações da dialética do mando local em relação ao poder central - especialmente no que se refere às práticas de negociação abertas ou conquistadas por grupos de elites das periferias do Império Português. Nesse sentido, o conceito de "autoridades negociadas" desenvolvido por Jack Greene" é fundamental para acompanharmos a movimentação dos partícipes da Conjuração Baiana de 1798, especialmente a do grupo de notáveis e suas estratégias políticas encetadas durante o período de 1796-1800.

Ao afirmar que a "autoridade" na periferia do Império Português é o resultado de constantes negociações e barganhas entre as partes envolvidas, Greene não flexibilizou o poder central nem enalteceu uma aparente autonomia do poder local das margens do Império, pasteurizando o binômio centro/periferia. Ao contrário, pois como se terá

\footnotetext{
${ }^{96}$ A lista dos documentos analisados está no final desta tese.

97 Conforme a definição clássica da Lawrence Stone, "A prosopografia é a investigação das características comuns do passado de um grupo de atores na história através do estudo coletivo de suas vidas". O método empregado consiste em definir um universo a ser estudado e então a ele formular um conjunto de questões padronizadas - sobre nascimento e morte, casamento e família, origens sociais e posições econômicas herdadas, local de residência, educação e fonte de riqueza pessoal, ocupação, religião, experiência profissional e assim por diante. Segundo Flávio Heinz, o propósito da prosopografia é dar sentido à ação política, ajudar a explicar a mudança ideológica ou cultural, identificar a realidade social, descrever e analisar com precisão a estrutura da sociedade e o grau e a natureza dos movimentos que ocorrem no seu interior. Cf. Flávio M. Heinz. Por outra história das elites. Rio de Janeiro: Ed. FGV, 2006 , p. 9.

98 Jack P Greene. Negotiated authorities. Essays in colonial political and constitutional history. The University Press of Virginia, 1994, passim.
} 
oportunidade de demonstrar, toda negociação ocorreu e só podia ocorrer dentro de uma margem de possibilidades dada pelo centro, sem que para isso houvesse eliminação do conflito e do caráter impositivo das autoridades metropolitanas. Ao ressaltar a natureza compósita da monarquia portuguesa, Greene defende a tese de que para a cooperação das elites locais, os agentes do poder tinham de negociar as autoridades com esse setor para manter um delicado equilíbrio entre os interesses locais e os interesses do poder central que, no final das contas, tiravam inúmeras vantagens dessas situações. A questão central que a tese de Jack Greene sugere para esta tese é saber se a participação da corporação dos enteados na Conjuração Baiana de 1798 representou o colapso no equilíbrio entre os interesses locais e metropolitanos. Em outros termos: se o enquadramento do problema é a Crise do Antigo Sistema Colonial, teria a participação do grupo de notáveis na Conjuração Baiana de 1798 acelerado o colapso do sistema ou representado uma ampla negociação ou "acomodação" com a metrópole, como sugere Kenneth Maxwell, e, portanto, a sobrevida do sistema?

Para o bom termo dos objetivos propostos, está tese é apresentada em três capítulos. No primeiro analisou-se a relevância política e econômica da capitania da Bahia para o Império Português, demonstrando-se que o modo de governar da coroa portuguesa "a bem das circunstâncias", no final do século XVIII, encontrou ressonância no modo de governar de d. Fernando José de Portugal e Castro, que a partir de sua proximidade política com a corporação dos enteados, sobretudo com o Secretário de Estado e Governo do Brasil, transformou a capitania da Bahia em um importante centro decisório da política colonial do Império Português e chamou atenção da coroa portuguesa sobre sua capacidade governativa ao preservar os interesses dos notáveis soteropolitanos para a manutenção da exploração colonial.

No segundo capítulo analisaram-se os pontos mais polêmicos do reformismo ilustrado de d. Rodrigo de Sousa Coutinho que contrariava os interesses da corporação dos enteados, especialmente do Secretário de Estado e Governo do Brasil, José Pires de Carvalho e Albuquerque. Apesar de esse grupo de notáveis ser composto pelos proprietários dos escravos entregues à justiça durante as investigações da Conjuração Baiana de 1798, demonstrou-se que suas atuações nos cargos públicos da capitania da Bahia contavam com o alinhamento político e econômico de uma série de outros funcionários régios cuja proximidade lhes legitimava como setor dominante, à medida que várias demandas desses funcionários eram efetivadas por meio de "atestações" da corporação dos enteados. Nesse capítulo demonstrou-se a maneira pela qual os altos 
setores da capitania da Bahia se organizaram e estabeleceram uma aliança programática com os milicianos para explicitarem suas demandas políticas e econômicas nos boletins manuscritos publicados nas ruas de Salvador.

No terceiro capítulo, portanto, tratou-se da resposta do poder local e da coroa portuguesa sobre o desafio imposto pelos que compunham o Partido da Liberdade, homens dos médios e altos setores da sociedade soteropolitana da época. Analisou-se a condução das investigações por meios das informações das devassas do movimento, demonstrando o recuo político da corporação dos enteados no processo, fazendo "pronta entrega" de seus escravos e denunciado a participação exclusiva dos milicianos que foram, ao final das investigações, condenados à pena de morte por enforcamento seguido de esquartejamento dos corpos. Revelou-se nesse capítulo a força desse grupo que ultrapassou o limite da consciência possível do "fazer política" em uma sociedade colonial escravista, levando a coroa portuguesa a empreender uma série de soluções de compromisso que afastasse definitivamente a desconfortável condição de "enteados" para restituir-lhes a condição de "súditos" do Império Português, em outras bases. 


\section{Capítulo 1}

\section{Tempos de tensão: 1796-1798}




\subsection{A capitalidade da Bahia setecentista no Império Português}

De acordo com vários relatos de viajantes e de contemporâneos ${ }^{99}$, a combinação do comércio de exportação com as atividades administrativas transformaram o povoado fundado em 1549, por Tomé de Sousa, em uma dinâmica cidade, cujo florescimento resultou no limiar do século XVIII na reconfiguração da malha urbana e seu recôncavo com várias obras e reformas como a construção de novas fontes e o conserto das existentes, a construção de praças, a pavimentação de ruas e ladeiras ${ }^{100}$, para dinamizar o fluxo de pessoas e intensificar o transporte de mercadorias entre a cidade alta e a cidade baixa, e a cidade e seu recôncavo ${ }^{101}$.

Segundo o professor régio de língua grega, Luís dos Santos Vilhena, um dos principais cronistas do "viver em colônia", na Bahia do final do século XVIII, o recôncavo baiano abrangia a cidade de Salvador com suas freguesias na margem norte e suas vilas: São Francisco do Conde e Santo Amaro da Purificação na margem norte; Cachoeira no oeste; e Maragogipe e Jaguaripe no sul. Para o cronista o recôncavo baiano estendia-se de 6 a 10 léguas em todas as direções a partir das margens de sua belíssima baía $^{102}$. Em razão dos solos argilosos de massapés dessa enorme região, os primeiros colonizadores e seus descendentes rapidamente aproveitaram-na para o plantio da cana de açúcar e a construção de engenhos, cujo transporte era facilitado por sua proximidade à baía e seu porto ${ }^{103}$.

A oeste da região do recôncavo baiano, na Vila de Cachoeira, e ao sul, nas Vilas de Maragogipe e Jaguaripe, os solos eram mais leves e arenosos, propícios para o cultivo do tabaco e da mandioca - produtos essenciais para o comércio com a Europa e África Central e para o abastecimento interno da colônia. Além disso, as freguesias de

\footnotetext{
${ }^{99}$ Fr. Antônio de Santa Maria Jaboatão. Novo Orbe Seráfico Brasílico. Recife, Assembleia Legislativa, 1979, 3 t.; José Antônio Caldas. Notícia geral de toda esta capitania da Bahia desde o seu descobrimento até o presente ano de 1759 (1759). Edição fac-similar. Salvador. Tipografia Beneditina Ltda., 1951; Luís dos Santos Vilhena. Notícias Soteropolitanas e Brasílicas. Salvador: Itapuã, 1969. 3 vols.

${ }^{100}$ Avanete Pereira Sousa. Poder local, cidade e atividades econômicas: Bahia, século XVIII. Tese de Doutorado, DH/FFLCH/USP, 2003, Capítulo 1, pp. 32-33.

${ }^{101}$ Pedro de A Vasconcelos. Salvador: Transformações e Permanências (1549 - 1990). In: Berta. K. Becker et alii. (Orgs). Geografia e Meio Ambiente no Brasil. São Paulo. São Paulo: Hucitec, 1995, pp. $97-117$.

${ }^{102}$ Cf. Luís dos Santos Vilhena, op.cit. pp. 477 et. Seq., vol. 2. Bert Jude Barickman afirma que os limites do recôncavo baiano descritos por Vilhena aproximam-se "notavelmente" da definição do recôncavo adotada pelo governo estadual da Bahia no início do século XXI. Ler: Bert Jude Barickman. Um contraponto baiano: açúcar, fumo, mandioca e escravidão no Recôncavo, 1780-1860. Rio de Janeiro: Civilização Brasileira, 2003, p. 39.

${ }^{103}$ Bert Jude Barickman, op.cit.
} 
Barra do Rio de Contas, Boipeba, Cairú, Camamú, as três últimas pertencentes à Capitania de Ilhéus, tinham sua economia centrada basicamente na produção de gêneros alimentícios, no extrativismo e na pesca. Cada uma das freguesias possuía uma jurisdição própria, os limites territoriais de influência de sua câmara, e tinham dependentes de si outras povoações menores, espalhadas pelo litoral e nas margens dos rios que deságuam no Atlântico. Separadas umas das outras por uma fisiografia intensamente recortada por rios e passagens de tais vilas, todas litorâneas, dependiam intensamente da navegação para se comunicarem, bem como para alcançar o mercado de Salvador, onde eram vendidos os gêneros que produziam, e adquiridos outros produtos $^{104}$.

Assim, o processo de territorialização da capitania da Bahia esteve intimamente ligado à conformação da civilização açucareira ali estabelecida e à configuração de um determinado circuito regional de trocas que, tradicionalmente identificado à ideia de um "Recôncavo Baiano", apenas parcialmente encontra nesse acidente geográfico a razão de seu desenho espacial ${ }^{105}$. Para Milton Santos, a navegação seria o fator determinante na conformação e integração dessas regiões, pois foi por ela que se operacionalizavam os processos econômicos que estiveram na raiz dessa formação regional, articulando a cidade de Salvador às vilas instaladas no entorno da Baía de Todos os Santos, próximas ao litoral ou nos diversos canais marítimos e fluviais navegáveis que lhe circundam ${ }^{106}$.

A dinâmica econômica do recôncavo baiano com a produção de gêneros de exportação e de subsistência transformou-a em uma das mais povoadas regiões do Brasil, cuja dimensão no final do século XVIII é bastante controversa. Luís dos Santos Vilhena e d. Miguel Antônio de Melo afirmam a existência de 60.000 pessoas no recôncavo baiano nos anos final do século XVIII ${ }^{107}$. Bert Jude Barickman, valendo-se dos dados censitários realizados pelo governo da capitania da Bahia e pela Igreja, afirma que, no final da década de 1780, a capitania da Bahia contava com cerca de 220 mil habitantes ${ }^{108}$. Thales de Azevedo afirma a existência de 100 mil habitantes para meados

\footnotetext{
${ }^{104}$ Cf. Caio Figueiredo Fernandes Adan. Ouvidores e Camarários na Colonial Comarca de Ilhéus (17501777). Mneme - Revista de Humanidades. UFRN. Caicó (RN), v. 9. n. 24, Set/out. 2008.

${ }^{105}$ Caio Figueiredo Fernandes Adan. Colonial Comarca dos Ilhéus: soberania e territorialidade na América Portuguesa (1763-1808). Dissertação de Mestrado/FFCH/UFBA, 2009.

${ }^{106}$ Milton Santos. A rede urbana do Recôncavo. In Brandão, Maria (Org.), Recôncavo da Bahia: sociedade e economia em transição. Salvador: Fundação Casa de Jorge Amado; Academia de Letras da Bahia; Universidade Federal da Bahia, 2008.

107 Vilhena, op.cit., pp. 459-460, vol. 2. AHU_CU_Baía, caixa 205, doc. 14690: Informaçan sobre a Bahia.

${ }^{108}$ Barickman, op.cit., p. 45.
} 
do século ${ }^{109}$. Dauril Alden, por sua vez, afirma que em 1780, a cidade do Rio de Janeiro contava com 38.707 habitantes. No mesmo ano, a capitania da Bahia possuía 193.598 pessoas, sendo que dessas, 170.489 viviam na capital e cercanias ${ }^{110}$.

Seja como for, parece inegável que a população da cidade de Salvador durante todo o século XVIII cresceu em ritmo acelerado em comparação ao de outras capitanias do Brasil ${ }^{111}$. O avanço demográfico, a dinamização das atividades econômicas e o aprimoramento do aparelho burocrático - a cidade foi o centro administrativo da colônia e do único vice-reinado no mundo atlântico até 1763, sede da única Relação do Brasil até 1751 e sede do único bispado até 1676 e depois do arcebispado do Brasil - fizeram com que a Salvador do final do século XVIII, segundo Luís dos Santos Vilhena, fosse uma sociedade com várias corporações: magistrados; financistas; clero; militares; comerciantes, além do povo pobre e mecânico, e escravos ${ }^{112}$.

Tais características colaboraram para que Salvador desempenhasse um papel administrativo importante para além da extensão territorial do Brasil em relação à governança e defesa dos territórios portugueses na África, no Golfo de Benim e no Estado da Índia, constantemente incentivado pelas autoridades régias naquele final de século $^{113}$. Para Kátia Mattoso, esse esforço das autoridades decorria da tríplice vocação da cidade: a função de cidade administrativa e religiosa; a função comercial como o principal porto da América de importação e exportação das mais variadas mercadorias e a dinamização das construções navais; e a função de centro redistribuidor de mercadorias vindas da Europa, da Ásia e da África para outras regiões do Brasil ${ }^{114}$.

Segundo Russel-Wood, a Baía de Todos os Santos era um ponto de congregação de embarcações da Carreira da Índia e das carreiras africanas e europeias, além de um ponto central para o comércio de cabotagem ${ }^{115}$. Sua geografia estratégica a transformou em um centro para a construção de caravelas, bergantins e mesmo galeões e naus. Amaral Lapa calcula que cerca de 30 embarcações para alto-mar foram construídas na Bahia, no período de 1665 e 1822. Destas, pelo menos 14 navegaram em rotas para a

\footnotetext{
${ }^{109}$ Thales de Azevedo. Povoamento da Cidade de Salvador. Salvador: Itapuã, 1969, p. 150.

${ }^{110}$ Dauril Alden. The Population of Brazil in the Late Eighteenth Century: a preliminar study. HAHR, 43:2, maio de 1963, pp. 173-205.

${ }^{111}$ Cf. Avanete Pereira Sousa, op.cit., p. 32.

${ }^{112}$ Luís dos Santos Vilhena, op.cit., p. 56.

113 Anthony John R. Russel-Wood. A dinâmica da presença brasileira no Índico e no Oriente. Séculos XVI-XIX. Topoi, Rio de Janeiro, set. 2001, pp. 9-40.

${ }^{114}$ Cf. Kátia Mattoso, op.cit., p. 285; José Roberto do Amaral Lapa. A Bahia e a Carreira da Índia. São Paulo: Companhia da Editora Nacional, Coleção Brasiliana, volume 338, 1968.

${ }^{115}$ Russel-Wood, op.cit.
} 
Ásia, e outras podem ter sido integradas em algumas partes da Carreira da Índia, indicando que produtos baianos eram transportados para o Índico em embarcações construídas em Salvador ${ }^{116}$.

Salvador era considerada a mais dinâmica cidade do Império Português, pois no século XVIII, concentrava as principais riquezas da colônia, o corpo burocráticoadministrativo mais especializado e um dos portos mais dinâmicos da costa americana $^{117}$. O florescimento da cidade e a situação estratégica da capitania da Bahia, no entanto, não impediram que no período do Marquês de Pombal (1750-1777) houvesse a transferência da sede do Vice-Reinado para a capitania do Rio de Janeiro. Os historiadores costumam afirmar que após a criação do Tribunal da Relação do Rio de Janeiro $(1751)^{118}$, tal mudança ocorreu em razão do crescimento populacional no sul do Brasil, da importância da zona mineradora nas Minas Gerais e da constante ameaça militar nas fronteiras meridionais da colônia ${ }^{119}$.

O entendimento que se faz da mudança da capital do Vice-Reinado para o Rio de Janeiro, via de regra, traz subjacente a ideia de que a capitania da Bahia deixa de ter importância política e administrativa no quadro geral das capitanias do Brasil e no

\footnotetext{
116 Amaral Lapa, op.cit., p. 51-81.

${ }^{117}$ Cf. Affonso Ruy. História da Câmara Municipal da Cidade de Salvador. Salvador: Câmara Municipal de Salvador, 2003; A.J.R. Russel-Wood. Fidalgos e filantropos: a Santa Casa da Misericórdia da Bahia, 1550-1755. Brasília: UnB, 1981; José Jobson de Andrade Arruda. A circulação, as finanças $e$ as flutuações econômicas. In: Nova história da expansão portuguesa, o império luso-brasileiro 1750-1822. Lisboa: Estampa, 1986, vol. VIII; Kátia Mattoso, op.cit; Maria José Rapassi Mascarenhas. Fortunas coloniais - Elite e riqueza em Salvador 1760 - 1808. Tese de Doutorado, DH/FFLCH/USP, 1999; Stuart B Schwartz. Segredos Internos: engenhos e escravos na Sociedade Colonial: 1550-1835. São Paulo: Cia das Letras/ CNPq, 1988; Stuart B Schwartz. Burocracia e sociedade no Brasil colonial: o Tribunal Superior da Bahia e seus desembargadores, 1609-1751. São Paulo: Companhia das Letras, 2011; Vera Lúcia Amaral Ferlini. Terra, Trabalho e Poder: o mundo dos engenhos no Nordeste colonial. Bauru: EDUSC, 2003.

118 Apesar de não ter avançado sua análise até a segunda metade do século XVIII, Stuart Schwartz entende que a autoridade do Tribunal da Relação da Bahia diminuiu muito com a criação do Tribunal da Relação do Rio de Janeiro. A documentação sugere que tal afirmação não procede. Primeiro porque o Tribunal da Relação do Rio de Janeiro não alcançava a jurisdição do Tribunal da Relação da Bahia, que, no final do século XVIII, envolvia o Golfo da Guiné e as Ilhas de São Tomé e Príncipe, por exemplo. Depois, a documentação também demonstra que no final do século XVIII os desembargadores almejavam um lugar na Relação da Bahia, e não do Rio de Janeiro, como o topo da carreira de um magistrado. Sobre o Tribunal da Relação da Bahia e o Tribunal da Relação do Rio de Janeiro, ler, respectivamente: Stuart Schwartz. Burocracia e Sociedade no Brasil Colonial: o Tribunal da Relação da Bahia e seus desembargadores, 1609-1751. São Paulo: Perspectiva, 1985; Arno Wehling \& Maria José Wehling. $O$ direito e a justiça no Brasil Colonial: o Tribunal da Relação do Rio de Janeiro (1751-1808). Rio de Janeiro: Renovar, 2004.

${ }^{119}$ Sobre a mudança da sede do Vice Reinado para o Rio Janeiro, ler, especialmente: Avanete Pereira Sousa, op.cit.; A. J. R. Russel-Wood. Centros e periferias no mundo luso-brasileiro,1500-1808. Rev. bras. Hist., São Paulo, v. 18, n. 36, 1998; Bert Jude Barickman, op.cit.; Stuart Schwartz, op.cit.; Vera Lúcia Amaral Ferlini, op.cit.
} 
Império Português como um todo, tornando-se subalterna ao Vice-Reinado no Rio de Janeiro.

A ideia de centralidade política do Vice-Reinado no Rio de Janeiro está relacionada a dois fenômenos. O primeiro é a crise de exportação do açúcar baiano nas décadas de 1770-1780, cujo valor total foi a metade do que tinha sido em 1760, deixando o Brasil com apenas $10 \%$ do mercado açucareiro atlântico ${ }^{120}$. Se a produção do açúcar na Bahia entrava nessas duas décadas em declínio persistente, como entendeu Schwarz, o Rio de Janeiro passou a ocupar lugar de destaque nas exportações brasileiras de açúcar e na produção de aguardente, muito utilizado na compra de escravos para as áreas mineradora ${ }^{121}$.

O segundo fenômeno relaciona-se justamente com a dinamização da economia carioca, que para alguns especialistas confirmou a "importância da capitania do Rio de Janeiro para a sustentação da monarquia e do império português" a partir da segunda metade do século XVIII ${ }^{122}$. A argumentação está na capacidade articuladora do Rio de Janeiro que, já no século XVII, ia muito além do recôncavo da Guanabara, proporcionando-lhe "condições excepcionais de trânsito entre as possessões espanholas do estuário do Rio da Prata e os enclaves negreiros na África, conferindo-lhe uma dimensão aterritorial, atlântica"123. Segundo Maria Fernanda Bicalho, a capitalidade do Rio de Janeiro no império português se consolidou a partir da transferência da sede do Vice-Reinado para a capitania, quando a política metropolitana e o cuidado dos governantes em relação à defesa e segurança da então cidade-capital da colônia sofreram um ponto de inflexão, transformando-a no "principal porto do Atlântico Sul',124.

Se é verdade que, após 1763, a cidade-capital do Rio de Janeiro se constituiu em ponto de articulação de toda a região meridional do império português em razão da dinamização da economia, da produção aurífera nas Minas Gerais e da luta prolongada com a Espanha na fronteira meridional do Brasil, durante o período de 1762-1777, a documentação sugere que a capitalidade do Rio de Janeiro, como "sustentação da

\footnotetext{
${ }^{120}$ Cf. Stuart Schawrz. Segredos Internos, op.cit., pp. 339-340.

${ }^{121}$ Cf. Sílvia Hunold Lara. Campos da violência: escravos e senhores na capitania do Rio de Janeiro, 1750 -1808. Rio de Janeiro: Paz e Terra, 1988.

${ }^{122}$ Maria Fernanda Bicalho. As noções de capitalidade no Rio de Janeiro sob a política pombalina. In: Ana Cristina Araújo; José Luís Cardoso et all. O terremoto de 1755: impactos históricos. Lisboa: Livros Horizontes, 2007, p. 261.

${ }^{123}$ Maria Fernanda Bicalho. O Rio de Janeiro no século XVIII: a transferência da corte e a construção do território centro-sul da América Portuguesa. Urbana, ano 1, nº. 1, set/dez, 2006, p. 7.

${ }^{124}$ Idem, p. 20.
} 
monarquia e do império português”, na última década do século XVIII, merece ser vista com cautela, ao menos não com exclusividade, especialmente se considerarmos a nova forma de articulação entre a metrópole portuguesa e suas colônias decorrente do aprofundamento geral da crise do Antigo Regime ${ }^{125}$.

Chamando atenção para o caráter estrutural e para o enorme potencial transformador na metrópole e na colônia da política industrialista portuguesa empreendida a partir de meados do século XVIII, sobretudo com as diretrizes do Marquês de Pombal, Jobson Arruda afirma que apesar das dificuldades políticas, especialmente no quadro das relações diplomáticas, a política exterior portuguesa aproveitava ao máximo as possibilidades inscritas no princípio da neutralidade. Para o autor

"o auge da produção aurífera no Brasil correspondera a
persistentes déficits na balança comercial portuguesa em
relação à Inglaterra. Paradoxalmente, o colapso na
exploração de metais equivale ao período em que a balança se
equilibra e, nos finais do século, torna-se mesmo
superavitária em relação aos ingleses" $" 126$.

Não há dúvidas de que a conjuntura de prosperidade na última década do século XVIII deveu-se à diversificação da produção colonial, à integração de seus mercados internos e externos, e a fatores externos como a revolução industrial, a guerra de independência americana e os conflitos entre as potências europeias. Durante todo o século XVIII, apesar de o açúcar permanecer como o mais valioso artigo para exportação, a diversificação da economia colonial com a queda da produção aurífera fez com que fumo, couros, arroz e algodão ganhassem papel de destaque no processo de integração dos mercados internos da colônia e como importantes produtos de exportação, como o algodão e o tabaco ${ }^{127}$.

De acordo com Stuart Schwarz a notável recuperação da economia baiana, cujo auge é inegavelmente a última década do século XVIII, pode ser comprovada de várias maneiras. Afirma o autor que:

\footnotetext{
${ }^{125}$ Cf. José Jobson de Arruda. O Sentido da Colônia. Revisitando a Crise do Antigo Sistema Colonial. In: José Tengarrinha (Org). História de Portugal. São Paulo/ Bauru/Lisboa: EDUNESP/EDUSC/Instituto Camões. 2002, pp. 167-185.

${ }^{126}$ Idem, p. 178.

${ }^{127}$ Stuart B. Schwarz, op.cit., p. 343; Katia M.de Queirós Mattoso. Conjuntura e sociedade no Brasil no final do século XVIII: preços e salários as vésperas da Revolução dos Alfaiates, Bahia 1798. In: op.cit., pp. 33-56.
} 
"em 1759, havia 166 engenhos na capitania, dos quais 122 localizavam-se na Bahia propriamente dita e 44 em Sergipe. Em 1798, o total pode ter atingido quatrocentos engenhos, 260 deles na Bahia. [...] Entre 1796 e 1811, a exportação baiana de açúcar foi em média de 652.121 arrobas anuais. [...] Na década de 1770, a produção anual baiana foi estimada em 10 mil caixas (de açúcar). Esse número elevou-se um pouco no decênio seguinte, mas entre 1796 e 1811 a Bahia produziu em média mais de 16.300 caixas de quarenta arrobas por ano" ${ }^{, 128}$.

Jobson Arruda também demonstrou que no ano de 1796, a variedade de produtos baianos destinados para exportação chegou a 126, sendo que desse total apenas 13 representavam 83,2\% do valor global das exportações no período de 1796 a 1811. Por ordem de importância temos: açúcar branco, algodão, açúcar mascavado, couros secos, arroz, tabaco, cacau, café, vaquetas, aguardente, couros salgados, meios de sola e atanados. De acordo com o autor, em 1796 a Bahia exportou 16.546 caixas de açúcar sem levar em consideração a quantidade de meias caras de açúcar, caras de açúcar, meias arrobas de açúcar e de feixes de açúcar, ficando a capitania da Bahia com 29,5\% do total de $34,7 \%$ das exportações. O papel da capitania da Bahia para exportação pode ser comprovada a partir dos dados fornecidos por José Mariano Velloso, conforme tabela abaixo:

Dados da produção e comércio do açúcar brasileiro ao final do século XVIII, 1800.

\begin{tabular}{|c|c|c|c|}
\hline & Bahia & Pernambuco & Rio de Janeiro \\
\hline $\begin{array}{c}\text { Número de } \\
\text { engenhos }\end{array}$ & 146 & 246 & 136 \\
\hline Importação em réis & $1.070 .206 \$ 400$ & $834.140 \$ 000$ & $630.796 \$ 400$ \\
\hline $\begin{array}{c}\text { Produção anual em } \\
\text { caixas de 35 } \\
\text { arrobas }\end{array}$ & 14.500 & 12.300 & 10.220 \\
\hline $\begin{array}{c}\text { Exportação para } \\
\text { Portugal }\end{array}$ & 14.000 & 12.100 & 10.100 \\
\hline Ficam na terra & 500 & 200 & 120 \\
\hline
\end{tabular}

Fonte: Velloso, 1800, pp. 106-107 ${ }^{129}$.

\footnotetext{
${ }^{128}$ Stuart B. Schwarz, op.cit., pp. 343-346.

129 José Mariano Velloso. Extrato sobre os engenhos de Assucar no Brasil, e sobre o methodo já então praticado na factura deste sal essencial, tirado da obra Riqueza e Opulencia do Brasil, para combinar com os novos methodos, que agora se propoem debaixo dos auspicios de S. Alteza Real o Príncipe Regente Nosso Senhor. Lisboa: Typographia chalcograpica e litteraria do Arco do Cego, 1800.
} 
A Bahia exportou, ainda em 1796, 19.733 rolos de tabaco, provenientes da região de Cachoeira, seguido de Inhambupe e Santo Amaro da Purificação ${ }^{130}$. Considerando que a exportação da Bahia para a Índia, que durante o período de 1797 a 1800 totalizou: 25.492 arrobas, com um preço médio por arroba de $1 \$ 540^{131}$, o tabaco ocupou o segundo lugar na balança de exportação durante quase todo o século XVIII, perdendo apenas para o açúcar ${ }^{132}$. Além disso, do total das exportações dos produtos brasileiros, o algodão representava 24,4\%, sendo que em 1786 a Bahia aparece com parcela considerável desse mercando ${ }^{133}$, com exportações que variavam de 150 a 200 mil libras por ano, atingindo 8.362 sacas em $1796^{134}$.

No curso da notável participação da economia baiana para exportação no final do século XVIII, houve o desenvolvimento e o aperfeiçoamento de um significativo mercado interno voltado para o abastecimento, funcionando inclusive como alternativa viável às plantations ${ }^{135}$. Avanete Pereira de Sousa demonstra que, além do açúcar, tabaco e algodão, a pecuária destacou-se como importante atividade do Recôncavo para o consumo da capitania e para o abastecimento das áreas fumageiras e mineiras, ao longo do século XVIII. De acordo com a autora, justamente porque a carne tornara-se produto essencial à dieta da população, uma série de serviços especializados foram implementados para garantir a regularidade do abastecimento das regiões citadas: a criação de currais, talhos e regulamentação dessa atividade pela Câmara Municipal, possibilitando que a média anual comercializada entre 1791 e 1811 girasse em torno de 18 mil cabeças ${ }^{136}$.

Outro produto essencial ao abastecimento urbano e distritos açucareiros era a farinha de mandioca, conhecida a época como "farinha de pau”, que podia ser consumida de diversas maneiras e saciava a fome da população na falta de outros alimentos como a carne. Barickman demonstra que, no final do século XVIII, a demanda urbana de farinha de mandioca abrangia dois segmentos: os moradores da

\footnotetext{
${ }^{130}$ Caio Prado Júnior. Formação do Brasil contemporâneo. São Paulo: Brasiliense, 1989, p. 155.

131 Jean Baptiste Nardi. O fumo brasileiro no período colonial: lavoura, comércio e administração. São Paulo: Brasiliense, 1996, pp. 384-405.

${ }^{132}$ Cf. José Roberto do Amaral Lapa, op.cit., p. 64. Jean Baptiste Nardi, op.cit.

133 José Jobson de Andrade Arruda. A economia brasileira no fim da época colonial: a diversificação da produção, o ganho de monopólio e a falsa euforia do Maranhão. Rev. hist. [online]. 1988, n.119, pp. 3-21. Disponível em: <http://www.revistasusp.sibi.usp.br/scielo

${ }^{134}$ Cf. Caio Prado Júnior, op.cit., p. 148.

${ }^{135}$ Cf. Jude Bert Barickman, op. cit.

${ }^{136}$ Avanete Pereira Sousa, op.cit., pp. 38-39.
} 
cidade, com um padrão de consumo relativamente estável de um ano para outro, e o consumo das pessoas envolvidas na escravidão e seu comércio transatlântico, que flutuava de um ano para outro.

Em épocas de aumento da produção e formação de estoques, a Bahia exportava farinha para Rio de Janeiro, Minas Gerais, Alagoas, Espírito Santo, Sergipe, Pernambuco, Ceará e regiões da África. Durante os anos de 1792 e 1793, o Vice-Rei do Rio de Janeiro, $2^{\circ}$ Conde de Resende e os governadores de Pernambuco e de Angola solicitaram a d. Fernando José de Portugal e Castro porções consideráveis de farinha em razão da seca que assolava a produção de mandioca dessas regiões ${ }^{137}$. Em contrapartida, em épocas de crise, a Bahia importava farinha de São Vicente, Pernambuco, Espírito Santo, Rio de Janeiro, Santa Catarina e Pará ${ }^{138}$.

Além da demanda para o consumo da farinha ser enorme, o produto também era usado no tráfico de escravos, seja para comprar cativos ${ }^{139}$, seja para alimentar as praças africanas que forneciam escravos ou as embarcações que os traziam para essa margem do Atlântico ${ }^{140}$. Justamente por isso, o preço do alqueire de farinha alterava constantemente provocando graves crises de abastecimento, que obrigaram as autoridades dos dois lados do Atlântico a tomar uma série de medidas que regulamentassem o preço para o consumo e a fiscalização do seu mercado.

A principal medida foi a criação do Celeiro Público, em 1785, pelo então governador da capitania da Bahia, d. Rodrigo José de Meneses, estabelecendo o preço legal máximo de Rs\$640 por alqueire de farinha até a abolição desse limite, em $1795^{141}$. Inspirado nos Terreiros de trigo em Portugal, o Celeiro Público de Salvador funcionou como um mercado de estoque de farinha, milho, feijão e arroz que chegavam à cidade de barco, cujos funcionários tinham a tarefa de fiscalizar a cobrança do imposto de Rs.\$20 por alqueire dos produtos e combater as práticas monopolistas dos comerciantes que formavam reservas da farinha, sobretudo para vendê-la a preços altíssimos em tempos de carestia ${ }^{142}$. Para se ter uma ideia da variação do preço da farinha com o fim

\footnotetext{
${ }^{137}$ Afrânio Mário Simões Filho. Política de abastecimento na economia mercantil: o celeiro público da Bahia (1785-1866). Tese de Doutorado, FFCH/UFBA, 2011, p. 45-46.

${ }^{138}$ Cf. Jude Bert Barickman, op.cit.; Stuart B Schwarz, op.cit; Avanete Pereira Sousa, op.cit.

${ }^{139}$ Vera Lúcia Amaral Ferlini. Terra, trabalho e poder: o mundo dos engenhos no Nordeste colonial. Bauru: Edusc, 2003.

${ }^{140}$ Luiz Felipe de Alencastro. O trato dos viventes: formação do Brasil no Atlântico Sul. São Paulo: Companhia das Letras, 2000.

${ }^{141}$ Afrânio Mário Simões Filho, op. cit.

${ }^{142}$ Cf. Afrânio Mário Simões Filho, op. cit; Jude Bert Barickman, op.cit.; Stuart B Schwarz, op.cit; Kátia M de Queirós Mattoso, op.cit.
} 
do preço máximo estipulado pelas autoridades, em 1796, o preço do alqueire de farinha era \$740; em 1799, o alqueire subiu para $1 \$ 147^{143}$.

Outros produtos importantes para o abastecimento também tiveram uma alta de preço vertiginosa no final do século XVIII. Para Kátia Mattoso, o preço do açúcar na última década do século XVIII não se compara a elevação de outros alimentos, como o azeite de oliva que no período que 1792 e 1827 atingiu preços elevadíssimos em razão da saturação momentânea do mercado local. A carne bovina, por sua vez, teve seu preço regulado pelo poder público até 1796, quando as autoridades liberaram seu comércio, ocasionando uma acelerada alta de preço com ápice por volta de 1801. Por fim, o preço da farinha de mandioca acompanhou a curva dos demais produtos, que começaram a cair por volta de 1799 e 1800, em razão das guerras do Império Francês ${ }^{144}$. Esses dados comprovam a tese de que os preços dos produtos para o abastecimento acompanharam a notável intensificação da economia exportadora da capitania da Bahia no final do século XVIII, beneficiando, no entanto, apenas o setor da economia ligado a esse comércio e agravando o problema dos salários que não acompanharam o crescimento vertiginoso da economia de exportação e também de abastecimento na capitania ${ }^{145}$.

O diagnóstico de prosperidade econômica da capitania da Bahia é inegável, sobrepondo-se na última década do século XVIII ao valor total de exportações do Rio de Janeiro ${ }^{146}$. Além da variedade de produtos comercializados para exportação e para o abastecimento do mercado interno, a Bahia foi durante o século XVIII um dos principais portos de desembarques de cativos africanos. A Costa da Mina era o principal fornecedor de cativos para o porto de Salvador até que, nas três primeiras décadas do século XVIII, tal situação foi abalada por crises dinásticas nessa região e pela abertura do Caminho Novo, dinamizando o comércio de cativos entre o Rio de Janeiro e as Minas ${ }^{147}$. Mesmo assim, segundo Manolo Florentino, durante todo o século XVIII e os

\footnotetext{
${ }^{143}$ Cf. Bert Jude Barickman, op. cit., p. 146.

${ }^{144}$ Kátia M. de Queirós Mattoso, op.cit., pp. 40-43.

145 Jude Bert Barickman, op.cit.; Stuart B. Schwarz, op.cit; Kátia M de Queirós Mattoso, Da Revolução dos Alfaiates a riqueza dos baianos no século XIX, op.cit. Kátia Mattoso, inclusive, relaciona a alta dos preços dos produtos para o consumo e abastecimento como a principal causa da revolta deflagrada em 1798. O argumento é que apenas o setor ligado à economia de exportação beneficiou-se com o surto econômico no final do século XVIII. Justamente porque o surto da economia exportadora durou, segundo a autora, em torno de uma década, não houve tempo suficiente para o aumento dos salários que possibilitassem a compra de alimentos com preços altíssimos naquela conjuntura.

${ }^{146}$ Cf. José Jobson de Andrade Arruda. O Brasil no comércio colonial. São Paulo: Ática, 1980.

147 Alberto da Costa e Silva. Francisco Félix de Sousa, mercador de escravos. Rio de Janeiro: Nova Fronteira: Eduerj, 2000. Alberto da Costa e Silva. Um rio chamado atlântico: a África no Brasil e o Brasil na África. Rio de Janeiro: Nova Fronteira; UFRJ, 2003; José Roberto Amaral Lapa, op.cit.; Kátia Mattoso, op.cit.; Manolo Florentino; Alexandre Vieira Ribeiro; Daniel Domingues da Silva. Aspectos
} 
primeiros anos do seguinte a comunidade mercantil baiana reforçou seus laços comerciais e mesmo políticos com a Costa da Mina, proximidade que por vezes gerou reações por parte de Lisboa $^{148}$.

Durante o período pombalino (1750-1777), a liberação do comércio com a Costa da Mina, em 1756, o fim do sistema de frotas, em 1765, e a redução dos valores dos fretes, em 1776, diminuíram sensivelmente os custos do comércio de escravos e possibilitaram o reflorescimento do tráfico negreiro na Bahia. Além dessas medidas, a revolta escrava em São Domingos, até então a maior produtora de açúcar, iniciada em 1791, possibilitou que os senhores de engenho e os traficantes baianos, as mesmas pessoas em alguns casos ${ }^{149}$, tirassem muita vantagem dessa situação.

Além de o número de engenhos na capitania da Bahia ter quase triplicado na última década do século XVIII, como demonstrou Stuart Schwarz, a quantidade de navios que partiram anualmente de Salvador para África pulou de 10, durante o período de 1788 e 1792, para 17, durante o período de 1793 e $1798^{150}$. Esses dados demonstram que o reflorescimento da economia baiana no final do século XVIII implicou, especialmente, no estreitamento das relações políticas e comerciais entre Salvador e Costa da Mina, impulsionando o tráfico negreiro entre essas regiões de tal forma que durante o período de 1776 e 1810 a participação declarada da África Ocidental no comércio baiano era de $71 \%{ }^{151}$.

Ainda que o tráfico negreiro do Rio de Janeiro tenha florescido após a abertura do Caminho Novo, após a abertura dos Portos, em 1808, e após a vertiginosa demanda por cativos nas fazendas de café do Vale do Paraíba fluminense, importa destacar para os objetivos desta tese que durante o período entre 1701 e 1830:

comparativos do tráfico de africanos para o Brasil (séculos XVIII e XIX). Revista Afro-Ásia, n 31, 83126, 2004; Stuart B. Schwartz, op.cit.

${ }_{148}$ Manolo Florentino, Alexandre Vieira Ribeiro; Daniel Domingues da Silva, op.cit, p. 84.

${ }^{149}$ APEB, Inventário: Caetano Maurício Machado: 03/1145/1614/06. É o caso de Caetano Maurício Machado, natural de Lisboa, proprietário de escravos entregues a justiça para as investigações da Conjuração Baiana de 1798. Professo na Ordem de Cristo, Sargento-mor do Regimento de Infantaria Auxiliar. Ajudante de Ordens do Governo da Capitania da Bahia, no final do século XVIII. Negociante e sócio proprietário de algumas embarcações que traficavam escravos para Costa da Mina. Casado com d. Caetana Joaquina de Fonseca Machado que, em 1807, aparece como proprietária dos engenhos Mombaça e Campo. É o caso também de Francisco Vicente Viana, bacharel pela Universidade de Coimbra. Juiz dos Órfãos e Ouvidor da Bahia da parte do Norte. Futuro Barão do Rio das Contas e Presidente da Província da Bahia (1823-1824). Casado com Emília Augusta Moniz Bulcão, filha de José Moniz Barreto de Aragão, Barão de Itapororocas. Sócio do negociante e traficante de escravos Inocêncio José da Costa na arrematação dos contratos dos dízimos. Proprietário dos engenhos Madruga Cedo, Paramerim e Monte.

${ }^{150}$ Manolo Florentino et all, p. 87.

${ }^{151}$ Idem, p. 93. 
"o porto do Rio de Janeiro foi responsável por metade das importações brasileiras e Salvador por quase $30 \%$ das mesmas. Juntos, ambos os portos foram responsáveis por quase um terço de todos os desembarques de africanos ocorridos nas Américas ao longo do século XVIII e durante as três primeiras décadas do século XIX",152.

Não parece exagerado destacar a inflexão da importância política da capitania da Bahia após a retomada vertiginosa de seu crescimento econômico, mesmo sem a condição de sede do Vice-Reinado ${ }^{153}$, pois de acordo com Arno Wehling:

"embora em tese o vice-rei no Rio de Janeiro tivesse certa preeminência sobre os demais governadores, a realidade é que jamais exerceu autoridade efetiva da Bahia para o norte e, ao sul, nada além do que uma vaga autoridade sobre os governadores de São Paulo, Minas Gerais, Goiás e Mato Grosso" ${ }^{\text {"154 }}$.

Arno Wehling refere-se aos inúmeros conflitos ocorridos entre os vice-reis, governadores e as demais autoridades, sobretudo no final do século XVIII, que caracterizavam a natureza intrinsecamente conflitual das relações de poder na colônia, que antes de significar ausência de racionalidade ${ }^{155}$ era a própria filosofia administrativa da coroa portuguesa. Tanto mais que, em 1796, foi o governador da capitania da Bahia quem escreveu para a coroa portuguesa sobre como o Vice-Rei e os demais governadores das capitanias deveriam agir em relação aos postos que vagassem nas tropas regulares ${ }^{156}$.

Cumpre destacar que, durante todo o século XVIII a capitania do Espírito Santo, por exemplo, ora se reportava ao governador da capitania da Bahia, ora ao Vice-Rei no

\footnotetext{
152 Ibidem, p. 97.

${ }^{153}$ Sobre a importância de Salvador no Império Português, ler: A. J. R. Russel-Wood. A projeção da Bahia no Império Português. Anais do IV Congresso de História da Bahia, Salvador: Instituto Geográfico e Histórico da Bahia/ Fundação Gregório de Matos, 2001, pp. 81-122; Avanete Pereira Sousa, op.cit.; Luís Henrique Dias Tavares. História da Bahia. São Paulo/Salvador: Unesp/UFBA, 2001, cap. XIV, pp. 192-205. Cumpre destacar que para Heloísa Belotto, durante o período de 1763 e 1808, o Vice Reinado adquire maior delegação de poderes, nomeadamente no campo militar, devido à nova conjuntura internacional, na qual a coroa portuguesa buscava maior centralização de poderes na colônia em razão do peso crescente do Brasil nas finanças régias. Cf. Heloísa Liberalli Bellotto. Vice-Reinado. In: Maria Beatriz Nizza da Silva (Coord). Dicionário da História da Colonização Portuguesa no Brasil. Lisboa: Editorial Verbo, 1994.

154 Arno Wehling. Administração Portuguesa no Brasil de Pombal a D. João (1777-1808). Brasília: FUNCEP, 1986, p. 46.

155 Cf. José Francisco de Oliveira Viana. Evolução do povo brasileiro. Rio de Janeiro: José Olympio, 1957; Rodolfo Garcia. Ensaio sobre a história política e administrativa do Brasil, 1500-1810. Rio de Janeiro: José Olympio, 1953, $2^{\text {a }}$. edição.

156 AHU_ACL_CU_005, Cx. 194, doc. 14134 “Carta do Governador e Capitão-general da Bahia, D. Fernando José de Portugal à Rainha sobre o que há de praticar o Vice-Rei, governadores e capitães gerais do Estado do Brasil, a respeito dos postos que vagarem nas Tropas Regulares".
} 
Rio de Janeiro. Se, por um lado, as extensas atribuições e poderes dos vice-reis e governadores lhes conferiam o controle de setores estratégicos da administração colonial: fazenda, guerra, igreja e justiça, por outro, a própria coroa portuguesa criava mecanismos de controle desses poderes, como as Relações, as juntas de justiças e de fazenda; órgãos que funcionavam como contrapeso à concentração de poderes nas mãos desses funcionários régios, especialmente os vice-reis ${ }^{157}$.

Além disso, a centralidade do poder dos Vice-Reis encontraram resistências na força e organização dos grupos locais. Em 1779, no final de seu governo, o Marquês de Lavradio lamentava o estado precário do comércio na capitania que estava nas mãos de pessoas de "nascimentos muito ordinários" e que, justamente por isso, era "todo cheio de dolo e falta de lisura", não podendo confiar nos comerciantes daquela praça, que não eram como os da Bahia, onde tinha sido governador ${ }^{158}$. O Conde de Rezende, por sua vez, afirmou em 1791 que a proeminência da sede do Vice-Reinado no Rio de Janeiro requeria "forças bem superiores àquelas que possam pertencer os Generais de outras Capitanias subalternas menos responsáveis e menos expostas" ${ }^{\prime 159}$. O argumento da proeminência política da capitania do Rio de Janeiro serviu para que o Conde de Rezende instituísse a obrigatoriedade de os negociantes que comerciavam alimentos do Rio Grande de São Pedro para o Nordeste escalassem naquele porto e pagassem os rendimentos da alfândega.

Maximiliano Menz demonstra que tal medida resultaria no pagamento dobrado de direitos e na tentativa da monopolização pelo Rio de Janeiro do comércio de abastecimento rio-grandense ${ }^{160}$; situações que criavam obstáculos ao crescente comércio de abastecimento entre a Bahia e o Rio Grande. Justamente por isso, os homens de negócio da Bahia enviaram uma representação para a coroa portuguesa contra tais medidas, fazendo com que Martinho de Mello e Castro determinasse o fim da obrigatoriedade da escala no Rio de Janeiro e seu sucessor, Luís Pinto de Sousa, o fim dos pagamentos de direitos na alfândega ${ }^{161}$.

\footnotetext{
${ }^{157}$ Cf. Arno Wehling, op.cit.; Dauril Alden. Royal Government in colonial Brazyl. Berkeley: UCP, 1968; Caio Prado Junior. Formação do Brasil Contemporâneo. São Paulo: Brasiliense, 1958; Kenneth Maxwell, op.cit.; Stuart B. Schwartz. Burocracia e Sociedade no Brasil colonial. São Paulo: Perspectiva, 1979.

${ }^{158}$ Cf. Maximiliano Mac Menz. Entre dois impérios: formação do Rio Grande na crise do antigo sistema colonial (1777-1822). 2006. Tese (Doutorado em História Econômica) - Faculdade de Filosofia, Letras e Ciências Humanas, Universidade de São Paulo, São Paulo, 2006, p. 67.

${ }^{159}$ Idem, p. 203.

${ }^{160}$ Ibidem, p. 204.

${ }^{161}$ Ibidem.
} 
Esse episódio confirma que a comunidade mercantil da Bahia, além de protestar contra a transferência da sede do Vice-Reinado e contra as reformas pombalinas, teve força e articulação política suficiente para impedir a criação de uma companhia monopolista na Bahia nos moldes das que foram criadas em Pernambuco e no Maranhão ${ }^{162}$. Em virtude da sua importância na economia de exportação, a comunidade mercantil da Bahia também reagiu à criação da Mesa da Inspeção, que tinha o objetivo de controlar a qualidade do açúcar e do tabaco exportados pela capitania, de fiscalizar seus preços e, sobretudo, de combater o contrabando ${ }^{163}$. Tereza Kischner mostra que não foram, entretanto, apenas os homens de negócio que reagiram à criação da Mesa da Inspeção da Bahia. Senhores de engenho e lavradores de cana reclamaram da fixação dos preços do açúcar e do aumento das taxas de armazenagem e de fretes. Argumentaram também que os preços do açúcar haviam sido fixados em níveis muito baixos em uma conjuntura de alta dos preços dos escravos.

Esses episódios demonstram que no final do século XVIII, a Bahia possuía, além de um setor agrícola em expansão, uma comunidade mercantil importante e consolidada que conduzia suas atividades no comércio atlântico por conta própria ou em parceria com correspondentes portugueses. Os negociantes da Bahia dedicavam-se a diferentes ramos do comércio, como o tráfico direto com o reino, com Angola, com a Costa da Mina e com outros portos da colônia, bem como e principalmente no financiamento para a produção de exportação. Para Alexandre Vieira Ribeiro, no final do século XVIII, a participação dos comerciantes baianos como agentes ativos de empréstimos tornou-se mais importante do que havia sido até então, decorrente do declínio financeiro de algumas instituições fornecedoras de crédito como a Santa Casa de Misericórdia, bem como da consolidação de algumas carreiras mercantis distintas de outras atividades $^{164}$.

A esse respeito, José da Silva Lisboa, em 1781, afirmou que:

[...] não obstante ter, ha 5 annos, quazi dobrado o valor dos assucares, comtudo não teria dobrado realmente a riqueza dos cultivadores: e com effeito assim succede. A conjunctura

\footnotetext{
162 Cf. Stuart Schwarz, op.cit., p. 340.

163 Sobre a Mesa de Inspeção na Bahia, ler: Tereza Kischner. A administração portuguesa no espaço atlântico: a Mesa da Inspeção da Bahia (1751-1808). In: Biblioteca Digital Camões. Disponível em: http://www.institutocamoes.pt Acessado em 23/03/2007.

${ }^{164}$ Alexandre Vieira Ribeiro. A cidade de Salvador: estrutura econômica, comércio de escravos, grupo mercantil (c.1750 - c.1800). Tese de Doutoramento. Rio de Janeiro, DH/IFCS/UFRJ, 2009; Rae Jean Dell Flory. Bahia Society in the Mid Colonial Period: the sugar planters, tobacco growers, merchants and artisans of Salvador and the Recôncavo, 1680-1725. Austin: University of Texas, 1978.
} 
favorável da guerra relativa do valor dos assucares, foi mais de vantagem para os ditos negociantes, do que para os lavradores, que sendo pela maior parte empenhados e por isso na continua sugeição dos mesmos negociantes, verão quazi absorver-se o beneficio da sua cultura pela exhorbitancia das uzuras dos seus assistentes ${ }^{165}$.

Catherine Lugar, por sua vez, afirma que essa dependência dos produtores, principalmente dos senhores de engenho, de crédito para o financiamento, tanto do investimento inicial, quanto das sucessivas safras, era muito comum desde meados do século XVIII. Em geral, senhores de engenho, lavradores de cana e plantadores de tabaco mantinham contas nas casas mercantis de Salvador, de onde recebiam tudo o que precisavam ao longo do ano, comprometendo-se a enviar o produto da safra para a casa mercantil que os financiava com taxa de $5 \%$ ao ano, estipulada pelo governo desde a década de $1750^{166}$.

A existência de uma forte organização mercantil financiadora da produção para exportação justifica a articulação dos negociantes da Bahia com senhores de engenho e lavradores com o objetivo de solicitarem ao governador e a coroa portuguesa a extinção da Mesa de Inspeção em razão dos arbítrios cometidos por seus oficiais, especialmente em relação à perda do monopólio sobre o comércio dos escravos ${ }^{167}$. Ocorre que se a coroa portuguesa cedeu em alguns momentos às reivindicações dos negociantes da Bahia, dessa feita, a coroa portuguesa manteve sua determinação, pois além de a Mesa da Inspeção não ter sido abolida, o âmbito da sua ação, com o tempo, foi ampliado ${ }^{168}$. Apesar de a coroa portuguesa não ter cedido à pressão política desse grupo, alguns desses homens, signatários de importantes reivindicações enviadas à coroa portuguesa ao longo do século XVIII, foram designados por Provisão Régia a ocupar postos na própria Mesa de Inspeção e nomeados administradores na Bahia da Companhia dos Vinhos do Alto Douro, criada em 10 de setembro de $1752^{169}$.

\footnotetext{
${ }^{165}$ AHU_CA, Baía, doc. 10.907: “Carta muito interessante do advogado da Bahia, José da Silva Lisboa, para o Dr. Domingos Vandelli, Director do Real Jardim Botânico de Lisboa, em que lhe dá noticia desenvolvida sobre a Bahia, descrevendo-lhe a cidade, as ilhas e villas da Capitania, o clima, as fortificações, a defesa militar, as tropas da guarnição, o commercio e a agricultura, e especialmente a cultura da canna de assucar, tabaco, mandioca e algodão. Dá também as mais curiosas informações sobre a população, os usos e costumes, o luxo, a escravatura, a exportação, as construcções navaes, o commercio, a navegação para a Costa da Mina, etc. Bahia, 18 de outubro de 1781".

${ }^{166}$ Catherine Lugar. The merchant community of Salvador. Tese de doutoramento, New York University, 1980.

${ }^{167}$ Jean Baptiste Nardi, op.cit., p. 257-261.

${ }^{168}$ Cf. Tereza Kischner, op.cit.

${ }^{169}$ Cf. Nardi, idem.
} 
É o caso de Frutuoso Vicente Viana, que foi um dos membros da Mesa do Bem Comum designado a exercer o posto de Deputado da Mesa de Inspeção da Bahia. Junto com o inspetor da Mesa, Francisco Xavier de Almeida, e outros principais comerciantes da praça da Bahia, Frutuoso Vicente Viana, após assumir seu posto na Mesa de Inspeção, propôs a criação de uma companhia de comércio chamada Companhia Geral da Guiné, que teria exclusividade do comércio com todos os postos da Costa da Mina, sendo proibida a presença de navios do Rio de Janeiro, permitindo apenas alguns de Pernambuco $^{170}$. Apesar de ser favorável à implantação de Companhias de Comércio, Pombal não julgou prudente vetar a liberdade de comércio que havia decretado e não aceitou a proposta dos comerciantes baianos, que, como se viu, tiveram força para barrar a criação de uma Companhia de Comércio anos antes.

No entanto, tais reivindicações não os impediram de ocupar postos em outros órgãos da administração local, como na Junta da Real Fazenda, criada para racionalizar a administração fiscal das capitanias ${ }^{171}$. É o caso do "especialista no tráfico atlântico" Inocêncio José da Costa, natural de Lisboa, irmão do Desembargador da Relação da Bahia Joaquim Casemiro da Costa, e do também "traficante atlântico" Clemente José da Costa. Inocêncio foi procurador da Administração do Tabaco, por volta de 1770, e Administrador do Celeiro Público durante o ano de sua implantação, 1785. Inocêncio ocupou também os prestigiosos cargos de Provedor da Santa Casa de Misericórdia, em 1782, tendo sido reeleito em duas oportunidades, e de Prior da Ordem Terceira do Carmo, sagrando-se benemérito ${ }^{172}$.

As reivindicações desses ricos negociantes também não os impediram de receber a Comenda da Ordem de Cristo, como é o caso novamente de Frutuoso Vicente Viana que nasceu na cidade de Viana do Castelo no Minho, no ano de 1711, e faleceu em Salvador em 1787. Foi o primeiro da família a fixar residência na Bahia, no ano de 1725, com 14 anos de idade, tendo sido em vida familiar do Santo Ofício, capitão do

\footnotetext{
${ }^{170}$ Alexandre Vieira Ribeiro, op.cit., p. 376. Bulcão Sobrinho, op.cit. Nardi, op.cit. A proposta de criação da Companhia de Comércio da Guiné foi elaborada por 12 comerciantes: Joaquim Inácio da Cruz, Manuel Álvares de Carvalho, Luís Coelho Ferreira, Francisco Xavier de Almeida, Frutuoso Vicente Viana, Antônio Cardoso dos Santos, Manuel Rodrigues Rios, José Antunes de Carvalho, José Álvares da Silva, José de Abreu Lisboa, Antônio Pereira de Araújo e Manuel Inácio Pereira. APUD Jean Baptiste Nardi.

${ }^{171}$ Cf. Arno Wehling, op.cit; Rodolfo Garcia. Ensaio sobre a história política e administrativa do Brasil: 1500-1810. Rio de Janeiro: José Olympio, $2^{\mathrm{a}}$. Edição, s. d.

${ }^{172}$ Cf. Afrânio Mário Simões Filho, op.cit.; Alexandre Vieira Ribeiro, op.cit; John Norman Kennedy. Bahian elites, 1750-1822. The Hispanic American Historical Review. Vol. 53, $\mathrm{n}^{\circ} .3$. The Duke University Press, 1973, pp. 415-439; Maria José Rapassi Mascarenhas. Fortunas coloniais: elites e riqueza em Salvador. Tese de Doutorado, DH/FFLCH/USP, 1998.
} 
Regimento dos Úteis e Vereador do Senado da Câmara, proprietários de prédios urbanos e de navios, que faziam o comércio marítimo com praças europeias e asiáticas. Em 1750, casou-se com Teresa de Jesus Gonçalves da Costa, nascida na cidade de Braga, no Minho. Tornou-se um rico negociante, proprietário de engenhos e, em 1768, arrematou o contrato dos dízimos reais por 125 mil cruzados e continuou arrematando por sucessivos triênios em sociedade com Clemente José da Costa, também sócio no comércio de cativos com a Costa da Mina ${ }^{173}$. Frutuoso Vicente Viana e os irmãos Inocêncio e Clemente José da Costa, também familiares do Santo Ofício, foram nomeados como membros do Regimento dos Úteis no ano de sua fundação, em 1774, juntamente com os principais homens de negócios da Bahia: entre eles, o Secretário de Estado e Governo do Brasil: José Pires de Carvalho e Albuquerque ${ }^{174}$.

As trajetórias de Frutuoso Vicente Viana e dos irmãos Costa demonstram que se por um lado a coroa portuguesa tentava recrudescer a fiscalização de todas as variáveis envolvidas no comércio para exportação com a criação das Mesas de Inspeção, das Juntas de Fazenda e do Celeiro Público, sobretudo no que dizia respeito ao controle do preço das mercadorias, a racionalização das finanças e o combate ao contrabando, por outro lado, a coroa colocava-se em uma situação delicada na medida em que alguns dos principais comerciantes traficantes de escravos, financiadores da economia exportadora e não raras vezes acusados de praticarem contrabando, eram recrutados a ocupar os postos dos órgãos da administração local, emprestando suas experiências de negócios para a gestão das finanças públicas e fiscalização de suas próprias ações ${ }^{175}$.

Maria José Rapassi Mascarenhas, em estudo sobre elite e riqueza em Salvador entre 1760 e 1808, demonstra a existência de pessoas de condições variadas aventurando-se na atividade comercial, dentre as quais homens de famílias importantes

\footnotetext{
${ }^{173}$ Frutuoso Vicente Viana era pai de Francisco Vicente Viana, um dos proprietários dos escravos entregues a justiça por ocasião das investigações dos culpados da Conjuração Baiana de 1798. Cf. Antônio de Aragão Bulcão Sobrinho. Famílias bahianas. Salvador: Imprensa Oficial, v. 1, 1945, p. 97. 174 Idem.

${ }^{175}$ Cf. Luciano Raposo de Almeida Figueiredo. Revoltas, fiscalidade e identidade colonial na América portuguesa - Rio de Janeiro, Bahia e Minas Gerais, 1540-1761. Tese (Doutorado em História) Faculdade de Filosofia, Letras e Ciências Humanas, Universidade de São Paulo, São Paulo, 1996. Para o autor, "ao ocuparem postos nos órgãos fiscais e participarem diretamente na gestão fazendária no Brasil, a cooptação de parte da elite colonial acaba por mitigar as tensões e os conflitos frontais que marcaram no campo da fiscalidade as relações colônia-metrópole ao longo dos séculos anteriores”, (v. 2, p. 500). Sobre o impacto das reformas na administração fazendária na segunda metade do século XVIII, ler, também: Kenneth Maxwell. Pombal e a nacionalização da economia luso-brasileira. In: Chocolate, Piratas e outros malandros: ensaios tropicais. São Paulo: Paz e Terra, 1999.
} 
de Portugal e da Bahia, que viam nessa atividade uma possibilidade bastante rentável de diversificação de suas riquezas e fortalecimento de seus prestígios políticos, como Antônio Cardoso dos Santos, Luís Coelho Ferreira, Inocêncio José da Costa, Clemente José da Costa e Frutuoso Vicente Viana. Para tanto, esses homens usavam seus próprios cabedais na exportação de produtos para os mercados internacionais dos quais importavam bens manufaturados e escravos ${ }^{176}$.

Para José da Silva Lisboa, essa comunidade mercantil ocupava lugar de destaque na economia exportadora da Bahia e, justamente por isso, beneficiava-se dessa situação, pois "os mesmos negociantes comprarão engenhos a dinheiro á vista e estes com a sua agricultura negociante conseguem mil interesses reunidos" ${ }^{\prime 77}$. Alexandre Vieira Ribeiro demonstra que cerca de $30 \%$ dos investimentos dos negociantes baianos no final do século XVIII eram direcionados para aquisição de bens agrários. Embora tivessem participado em apenas 8,6\% das transações, o montante aplicado por eles na aquisição de bens agrários representou $15,7 \%$ do total investido na segunda metade do século XVIII. Eram propriedades de plantação de cana-de-açúcar e tabaco na área do Recôncavo Baiano e fazendas de criação de gado no sertão. Nessas fazendas produziam o fumo e a aguardente indispensáveis no comércio em portos africanos ${ }^{178}$.

Como a maioria desses negociantes chegavam solteiros à Bahia, eles buscavam constituir matrimônio com as filhas da elite local, que via nessas alianças a possibilidade de usufruir do capital mercantil e das conexões com a Costa da Mina desses homens, que garantiam suas projeções sociais e políticas ${ }^{179}$. Muitos desses homens buscavam na governança local a garantia de seus interesses e a proteção de seus negócios, com isenções de taxas, favorecimento em disputas comerciais e até certa tolerância em atividades ilícitas, como o contrabando. Segundo Luís dos Santos Vilhena "talvez seja esta a causa por que das três praças Rio de Janeiro, Pernambuco, e Bahia, esta se reputa pela menos policiada, quando até agora a mais pecuniosa"180. Além disso, em razão da alta rentabilidade de seus empreendimentos, esses negociantes

\footnotetext{
${ }^{176}$ Avanete Pereira Sousa, op.cit., p. 51; Kátia M. de Queirós Mattoso. A riqueza dos baianos no século XIX. Revista Clio, Recife, no. 11, 1988, pp. 61-75.

177 AHU_CA, Baía, doc. 10.907.

178 Alexandre Vieira Ribeiro, op.cit., p. 389.

${ }^{179}$ Alexandre Vieira Ribeiro, idem; Catherine Lugar, op.cit; John Norman Kennedy, op.cit; Maria José Rapassi Mascarenhas, op.cit; Rae Jean Dell Flory, op.cit.

${ }^{180}$ Luís dos Santos Vilhena, op.cit., vol. 1, p. 56.
} 
podiam oferecer aos membros da administração local, oportunidades de negócios e vultosos empréstimos, muitos dos quais nunca saldados ${ }^{181}$.

No início de 1797, d. Miguel Antônio de Mello, Conde de Murça, governador de Angola, esteve em Salvador e relatou a d. Rodrigo de Sousa Coutinho, Ministro da Marinha e Ultramar, suas impressões sobre a estrutura e a dinâmica da cidade naquele tumultuado final de século em sua "Informaçam sobre a Bahia"182. Após apresentar um panorama geral da geografia da cidade e seu recôncavo, das fortalezas, das ordenações, dos regimentos de milícias e sobre os vários empréstimos abertos por editais públicos na capitania da Bahia no final do século XVIII, o Conde de Murça afirmou que: “[...] quanto ao Empréstimo que se mandou abrir de três milhoens de cruzados, nam o julgo imperdivel, porem sim muito dificultozo de completar, visto que tal he nossa desgraça que tem mais crédito hum Mercador que o Erário Régio [...]" ${ }^{\text {"183. }}$.

A "desgraça" mencionada pelo Conde de Murça relacionava-se ao aumento das despesas extraordinárias e ordinárias na folha da Capitania da Bahia, especialmente os gastos com a dinamização da marinha mercante portuguesa para fazer frente às constantes ameaças de ataques estrangeiros, especialmente da França e da Espanha, na costa brasileira e no golfo da Guiné. Nessa situação, segundo d. Miguel:

"grande parte do cabedal desta gente está empatado em Lisboa e no Porto, que as dificuldades da Navagaçam augmentam pelo temor de inimigos, que os Prêmios dos Seguros sam excessivos, o que tudo concorre para o Negociante se ver obrigado a ter maiores quantias em caixa do que em outro tempo, no qual o giro do Commercio he mais veloz," ${ }^{, 184}$.

Além de os preços dos seguros serem excessivos, os preços dos fretes terrestres estavam sobretaxados pela Junta da Real Fazenda da Bahia desde 1787, como uma

\footnotetext{
${ }^{181}$ Os editais públicos para empréstimos a Real Fazenda no final do século XVIII serão analisados adiante.

${ }^{182}$ Miguel Antônio de Melo, Conde de Murça. Informaçam sobre a Bahia. Grifo meu. Em forma de carta, o documento foi escrito em 30 de março de 1797, embora haja à esquerda uma observação de d. Rodrigo de Souza Coutinho "remeteu-se ao governador da Bahia um extrato desta carta, sem o nome de quem a escreveu, em setembro de 1798". Apesar da data, não há nenhuma referência à revolta baiana de 1798 . O autor do manuscrito, todavia, descreve minuciosamente a situação da Salvador da época decorrente do ele chama de "frouxidão" do governador, d. Fernando José de Portugal e Castro. Há uma cópia do documento na Biblioteca Nacional do Rio de Janeiro, Divisão de Manuscritos, I-31, 21, 34, doc. 1 e 2. Há uma cópia microfilmada cuja indicação é AHU_CU_Baía, caixa 205, doc. 14690. Guilherme Pereira das Neves afirma a existência de outra cópia da carta no IHGB, lata 358, pasta 28 e traz a data de 30 de março de 1797. Cf. Guilherme Pereira das Neves. Em busca de um ilustrado: Miguel Antônio de Melo (1766-1836). Acessado em 10 de janeiro de 2007 no sítio: www.realgabinete.com.br

183 Idem.

184 Ibidem.
} 
maneira de aumentar os rendimentos para as novas despesas públicas que se avolumavam. Tal medida não resolveu a crise financeira que se abatia na metrópole, apesar de o superávit da balança comercial ter gerado excesso de capitais durante a última década do século XVIII. Ocorre que o excesso de capital, como se viu no relato do Conde de Murça, permaneceu nas mãos de comerciantes do Brasil e da metrópole ${ }^{185}$, de maneira que a política da coroa portuguesa, a partir de 1796, teve por desafio o equacionamento do déficit das finanças régias com a monetização de sua economia ${ }^{186}$.

Das várias medidas propostas, por ora, destacam-se duas: a determinação régia para a emissão de apólices por decreto de 29 de outubro de 1796, sob a forma de empréstimos a prazo fixo e juros de 5 a $7 \%$ ao ano, com valor inicial de 10 milhões de cruzados. Esse valor foi ampliado nos anos posteriores em razão do sucesso do lançamento das apólices, obrigadas a serem usadas em 50\% das operações comerciais. Depois, a elaboração de um plano integrado, prevendo a criação de caixas de crédito para apoiar a agricultura e o comércio, a continuação das emissões de apólices e o estabelecimento de um banco emissor de "bilhetes" 187.

Tais medidas contrariavam os interesses dos comerciantes que intermediavam com relativa autonomia as relações entre senhores de engenho, lavradores e traficantes de escravos e seus representantes em Portugal e na África e, justamente, não queriam ter suas operações de crédito taxadas e fiscalizadas. Além disso, sabe-se que mesmo com todos os riscos que envolviam o empreendimento comercial no ultramar, o lucro obtido em tais transações e nos empréstimos concedidos para que elas se efetivassem podia ser muito superior ao rendimento fixado pelas emissões de apólices e emissão de "bilhetes",

Mesmo se considerarmos um cenário ruim, como não era o caso do Brasil no final do século XVIII, o comércio ainda era a melhor opção de investimento, pois segundo Guillaume Daudin, os investimentos feitos no comércio colonial francês no final do século XVIII proporcionaram uma taxa de retorno médio sobre o capital de $6 \%$,

\footnotetext{
${ }^{185}$ Cf. Stuart B. Schwarz, op.cit., 169-176; Dauril Alden. Vicissitudes of Trade in the Portuguese Atlantic Empire during the First Half of the Eighteenth Century: a review article. The Americas, v. 32, n. 2, October, 1975.

${ }^{186}$ Memória sobre os melhoramentos dos domínios de Sua Majestade na América (1797). Andrée Mansuy-Diniz Silva (Org.). D. Rodrigo de Souza Coutinho. Textos políticos, económicos e financeiros (1783-1811). Lisboa: Banco de Portugal, 1993. 2 v.

${ }^{187}$ Cf. Arno Wehling, op.cit., pp. 136-140.

${ }^{188}$ Cf. Amaral Lapa, op.cit.; Dauril Alden, op.cit.; Stuart B. Schwarz, op.cit., 169-176.
} 
tornando essa modalidade de rendimento mais importante que os títulos da dívida pública (que pagavam de $4 \%$ a 5,5\%) e da dívida privada (retorno de $5 \%)^{189}$.

Ademais, cumpre destacar que a implantação de caixas de crédito e a emissão de "bilhetes" requeriam uma série de ajustes na administração colonial relativas às finanças que desagradaram os governadores locais, sobretudo os da Bahia e do Rio de Janeiro, por vislumbrarem maior interferência da coroa em suas administrações, especialmente em relação ao balanço das finanças de suas respectivas capitanias, cuja demonstração passou a ser obrigatória naqueles anos finais do século XVIII.

Por tudo isso, os negociantes da Bahia recusaram terminantemente a criação de uma Caixa de Crédito para o financiamento da produção agrícola, contando, inclusive com apoio do governador. A coroa portuguesa, no entanto, não se conformava com o fato de os negociantes afirmarem falta de fundos para a implantação das caixas de créditos e aquisição das ações, especialmente porque àquela altura conhecia-se a “extensão das rendas" das capitanias comprovadas pelas balanças de comércio superavitárias nos quatro últimos anos do século XVIII. O fato é que na capitania da Bahia, d. Fernando José de Portugal e Castro, não quis se indispor com os negociantes e contrariar seus interesses, pois muitos deles foram os principais credores individuais da Real Fazenda por meio de empréstimos abertos por editais públicos, como opção paliativa para as finanças régias.

Em 20 de março de 1797, abriu-se edital público solicitando um empréstimo de três milhões de cruzados para a Real Fazenda entre os principais da capitania da Bahia $^{190}$. A dificuldade de se conseguir a quantia foi tanta que, em 4 de outubro de 1798, d. Rodrigo de Sousa Coutinho comunicou ao governador que S. M.:

"manda novamente recomendar o estabelecimento do Crédito Público dessa Capitania a fim de que o empréstimo a respeito do qual Vossa Senhoria nada me tem participado até agora se complete e que por esse meio se cumpram as despesas extraordinárias de que se trata, mas para outras maiores que ocorrerão ${ }^{191}$ ".

No entanto, em 23 de maio de 1797, d. Fernando escreveu a d. Rodrigo de Sousa Coutinho, comunicando que, como S.A.R recomendava que ele procurasse todos os meios de animar a feliz realização do empréstimo, o governador achou

\footnotetext{
${ }^{189}$ Cf. Guillaume Daudin. Profitability of Slave and Long-Distance Trading in Context: the case of eighteenth-century France. Journal of Economic History, vol. 64, n. 1, March 2004, p. 144-171.

${ }_{190}$ BN, Sessão de Manuscritos, MS-512, II-33, 18, 39.

${ }^{191}$ BN, Sessão de Manuscritos, Livro de Provisões Régias, 01, 04, 009, Ofícios 118 e 119. Grifo meu.
} 
"que hum delles [meios] e bem próprio era mandar chamar a minha presença todos aqueles comerciantes $e$ mais Pessoas desta Cidade, em quem considerei possibilidade de concorrerem com alguma porção de dinheiro e praticando-o assim e escrevendo igualmente cartas aos Senhores de Engenhos e Lavradores ricos que vivem distantes desta Cidade, resultou desta Nova Providência utilidade, tendo-se já prometido a soma de cento e trinta e três contos de réis dos quais ficão recolhidos nos Cofres Reais setenta e sete contos " ${ }^{192}$.

D. Fernando avançou em seus argumentos ponderando com o Ministro que não seria possível conseguir o empréstimo de três milhões de cruzados "por ser esta porção talvez a que gire nesta Capitania, o he muito mais nas circunstâncias actuais, em que o Comércio tem sofrido prejuízos não pequenos ${ }^{\prime 193}$. O governador concluiu sua carta afirmando que, para conseguir que os principais colaborassem com o avultado empréstimo, usou de toda a "suavidade e brandura como pede a natureza delle", e que os Vassalos chamados à sua presença:

\begin{abstract}
"mostrarão o ardente desejo de concorrerem com somas mais avultadas, se assim o permitissem as possibilidades, oferecendo-se até alguns a fazerem o empréstimo gratuito e sem interesse, o que não aceitei por me parecer não ser esta a mente e intenção da Mesma Senhora",194.
\end{abstract}

Em 11 de setembro de 1798, d. Fernando José de Portugal e Castro escreveu para d. Rodrigo de Sousa Coutinho, comunicando que havia conseguido até aquele momento a quantia de $196.800 \$ 000$ do total do capital subscrito ${ }^{195}$, sendo que a capitania do Rio de Janeiro não havia conseguido nem esse montante um ano depois, apesar das ações adotadas pelo Conde de Resende, relatadas em carta de 23 de setembro de $1799^{196}$. Apesar da insistência de d. Rodrigo de Sousa Coutinho em conseguir o montante do empréstimo e criar as caixas de crédito, em 9 de maio de 1800, d. Fernando José de Portugal e Castro observou:

"[...] parecendo-me que d'alguma sorte está conseguido este fim, se se refletir que cada um dos comerciantes desta praça em particular é uma caixa ou fundo de cada um dos lavradores, por consistir o comércio da Bahia em suprir aos

\footnotetext{
192 AHU_CU_CA_Cx. 89, doc. 17344

193 Idem.

194 Ibidem.

195 AHU_CU_CA, doc. 18380. “Officio do Governador D. Fernando .José de Portugal para D. Rodrigo de Sousa Coutinho, no qual se refere ao empréstimo de três milhões e participa a cobrança de 196:800\$000 do capital subscripto. Bahia, 11 de setembro de 1798”.

${ }^{196}$ AN, códice 68 , livro 15 , folhas $323,323 \mathrm{v}$.
} 
do tabaco e açúcar geralmente de todos os gêneros, dinheiro, fazendas e escravos, recebendo em seu pagamento as colheitas e trabalhos dos mesmos lavradores, havendo comerciantes que assistem a trezentos e quatrocentos lavradores de tabaco e a 12, 15, 20 e mais senhores de engenho[... $]^{, 197}$.

Uma das razões para d. Fernando José de Portugal e Castro ter defendido o interesse dos negociantes é que entre os colaboradores do montante arrecadado para o empréstimo de 3 milhões de cruzados estavam José Pires de Carvalho e Albuquerque e Francisco Vicente Viana, homens de muito cabedal, membros da administração local, contrários à criação das caixas de créditos e membros de famílias que há muito mantinham relações promiscuas com a governação local, com vultosas quantias emprestadas gratuitamente ${ }^{198}$.

No início do governo de d. Fernando José de Portugal e Castro na Bahia, em 1788, José Pires de Carvalho e Albuquerque emprestou gratuitamente aos cofres da capitania 123 mil cruzados, demonstrando ao governador sua influência no poder local $^{199}$. Em 1796, por exemplo, José Pires de Carvalho e Albuquerque emprestou gratuitamente a Real Fazenda 50 mil cruzados para o pagamento das despesas das esquadras que deviam comboiar os navios mercantes para Lisboa ${ }^{200}$. Um ano depois, ele foi um dos que mais contribuiu para a quantia arrecadada para o empréstimo de 3 milhões de cruzados, que d. Fernando José de Portugal e Castro relatou a d. Rodrigo de Sousa Coutinho ${ }^{201}$.

José Pires de Carvalho e Albuquerque tinha razões concretas para não querer a criação das caixas de crédito na Bahia. Por ocasião de seu inventário feito em 1808, o montemor do Secretário de Estado foi avaliado em 200:937\$000, com uma dívida ativa girando em torno de 26:000\$000, o que o tornava o maior senhor de engenho

\footnotetext{
197 AHU_CA, Cx. 105, doc. 20509. "Officio do Governador D. Fernando José de Portugal para D. Rodrigo de Sousa Coutinho, no qual o informa das dificuldades que se offerecia o estabelecimento das caixas de crédito".

${ }^{198}$ BN, Sessão de manuscritos, MS-512, II-33, 29, 74: "Forão recebidos por empréstimo gratuito dos cofres e pessoas abaixo declaradas [...] a saber: 20.000\$000 de José Pires de Carvalho e Albuquerque". ${ }^{199}$ BN, Sessão de Manuscritos, MS-512, II, 33, 18, 74.

${ }^{200}$ AHU_CU_CA, Baía, doc. 26146. "Attestado de Francisco Gomes de Sousa, escrivão da Junta da Real Fazenda, em que este declara que o Secretário de Estado José Pires de Carvalho e Albuquerque emprestara gratuitamente a Real Fazenda 50:000 cruzados para pagamento das despezas das esquadras que devia comboiar os navios mercantes. Bahia, 9 de março de 1796".

${ }^{201}$ AHU_CU_CA, Baía, doc. 26171. "Certidão da quantia com que o Secretário de Estado José Pires de Carvalho e Albuquerque entrou nos cofres da Real Fazenda para o empréstimo que se mandara abrir na Capitania da Bahia, em 8 de novembro de 1797".
} 
fornecedor de crédito ${ }^{202}$. Sua dívida passiva, no entanto, era de 25:082\$488, cerca de $12,5 \%$ de seu montemor, colocando-o na terceira posição como maior devedor da capitania da Bahia. A fortuna e os empréstimos gratuitos concedidos à Real Fazenda e a outros senhores de engenhos só reafirmavam a autoridade local de José Pires de Carvalho e Albuquerque como Secretário de Estado e Governo do Brasil.

Em 4 de junho de 1785, o então governador da Bahia, d. Rodrigo José de Menezes, foi agraciado com uma Petição na qual "a nobreza, cidadaons della e maior parte dos Negociantes e Povo" da capitania elogiavam as obras que o governador mandara fazer na cidade: construção de muralhas na cidade baixa, reforma nos currais, o celeiro público e a construção do hospital do lazareto, e solicitavam à S. M. fazer a "graça e mercê de conservar o mesmo Excellentíssimo Senhor General no Governo em que se acha para se não interromperem as mencionadas obras, como de ordinário se sucede na mudança dos governadores [...]".

$\mathrm{Na}$ mesma petição, os signatários solicitavam que "a este governo fosse restituída a qualidade e preeminência de Vice-Reinado tão merecida pela dignidade e primazia desta Cidade, pela riqueza da sua Capitania e pela sua natural situação no centro da America Portugueza”. Entre os signatários estavam: Cristovão da Rocha Pita, Diogo Alves Campos, Pedro Gomes Ferrão Castelo Branco, Adriano Antunes Ferreira, Frutuoso Vicente Viana (pai de Francisco Vicente Viana) e José Pires de Carvalho e Albuquerque $^{203}$.

Desse grupo, José Pires de Carvalho e Albuquerque, Secretário do Estado e Guerra do Brasil, tinha razões concretas para suas reivindicações. Em 20 de julho de 1766, seu pai de mesmo nome, desembargador, Alcaide-Mor da Maragogipe, Cavaleiro da Ordem de Cristo, Fidalgo da Casa de S. M., escreveu uma carta para a coroa portuguesa afirmando que tendo arrematado o ofício de Secretário do Estado do Brasil

\footnotetext{
${ }^{202}$ APEB, Judiciário, Inventário de José Pires de Carvalho e Albuquerque, 1808/01/97/141/02.

${ }^{203}$ Arquivo Municipal da Cidade de Salvador, doravante AMS, Ofícios do Governo (1768-1807), folhas 196, 197, 197 v. AHU_CU_CA, Baía, Caixa 61, docs: 11777-11782. Grifo meu. Cumpre destacar que, no final do século XVIII, havia quatro pessoas com o nome de José Pires de Carvalho e Albuquerque. O José Pires de Carvalho e Albuquerque que aparece no grupo de signatários da Petição citada nasceu na Bahia em 1703 e faleceu em 1776. Era Secretário de Estado, cargo vitalício que comprou por 30:000\$000, desembargador e membro da Academia dos Renascidos em 1724. Casou-se com d. Isabel Joaquina de Aragão e tiveram quatro filhos, entre eles o Secretário de Estado José Pires de Carvalho e Albuquerque, proprietário de quatro escravos entregues à justiça por ocasião das investigações da Conjuração Baiana de 1798. Sobre a família Pires de Carvalho e Albuquerque e Frutuoso Vicente Viana, ler: Antônio de Araújo de Aragão Bulcão Sobrinho. Famílias Bahianas (Bulcão, Pires de Carvalho e Vicente Viana), vol. 1, Bahia: Imprensa Oficial, 1945; Francisco Antônio Doria. Caramuru e Catarina: lendas e narrativas da Casa da Torre de Garcia d'Ávila. São Paulo: Senac, 2000, pp. 129-130; Luiz Alberto Moniz Bandeira. $O$ Feudo. A Casa da Torre de Garcia d'Ávila: da conquista dos sertões à independência do Brasil. Rio de Janeiro: Editora Civilização Brasileira, 2000, p. 324.
} 
por 30:000\$000, sentia-se lesado com a transferência da sede Governo Geral para o Rio de Janeiro e pedia a confirmação da referida propriedade e pagamento de propinas, pois, caso contrário, renunciaria ao seu ofício ${ }^{204}$. O então Secretário de Estado escreveu várias vezes para a coroa portuguesa valendo-se do mesmo argumento de prejuízo financeiro. Em 1 de agosto de 1770, afirmou que:

"he sem duvida que todos os rendimentos desta Secretaria e ainda os do Governo, se deteriorarão muito com a creação da Relação do Rio de Janeiro, com a passagem do Vice-Reinado para aquella Capitania e ultimamente com a resolução de $S$. $M$. de se não pagarem mais propinas, que dos contratos, que aqui se rematarem...",205.

No mesmo memorial, José Pires de Carvalho e Albuquerque lembrou a coroa portuguesa que além do prejuízo causado pela criação da Relação do Rio de Janeiro e pela transferência da sede do Vice-Reinado, sua família há muito contribuía para as finanças de S. M. Afirmou que no "curto" espaço de 30 anos pagou em Lisboa 30:000 cruzados de contado pela Alcaidaria-mor da cidade da Bahia, para seu irmão o ajudante de ordens "Salvador Pires de Carvalho e Albuquerque, que logrou este lugar o breve tempo de anno e meio e por sua morte vagou para a coroa". Pagou 52:000 cruzados e 100 mil réis pela arrematação que fez a Real Fazenda do "Trapiche de seu devedor Bernabé Cardoso, achando-se aquella propriedade depois da compra tão damnificada, que foi preciso faze-la de novo”. Além disso, pagou pela primeira vez 42:000 cruzados de contado pela propriedade vitalícia do ofício de Secretário de Estado do Brasil e na segunda vez pagou quase o dobro, 82:000 cruzados, pela mesma propriedade vitalícia do mesmo ofício, que àquela altura já tinha pagado aos cofres públicos 25 contos $688 \$ 88$ réis $^{206}$.

O pagamento duplo pela vitaliciedade do ofício de Secretário de Estado ocorreu porque, no início de 1764, o serventuário da Secretaria de Estado, Francisco Gomes de Abreu Lima Corte Real, requereu ao governo interino o exercício do ofício de Secretário de Estado no lugar de José Pires de Carvalho e Albuquerque, que se encontrava doente ${ }^{207}$. O Secretário de Estado reclamou e a coroa portuguesa intercedeu a seu favor, desde que ele pagasse novamente pela vitaliciedade de seu ofício, alegando

\footnotetext{
${ }^{204}$ AHU_CU_CA, Baía, doc. 7183.

${ }^{205}$ AHU_CU_CA, Baía, doc. 8285.

${ }^{206}$ Idem.

${ }^{207}$ AHU_CU_CA, Baía, doc. 7120. Cumpre destacar que Francisco Gomes de Abreu Lima Corte Real foi exonerado do cargo de Oficial Maior da Secretaria de Estado, sendo nomeado em seu lugar Antônio Pinheiro da Silva, homem de confiança da família de José Pires de Carvalho e Albuquerque.
} 
que na primeira vez não havia recebido quantia suficiente para um ofício de tamanha importância ${ }^{208}$. A vitaliciedade do cargo de Secretário de Estado significava, no limite, que a coroa portuguesa entregava a memória cartorial do Estado do Brasil e de todos os despachos trocados nos dois lados do Atlântico a um único indivíduo, nascido e com interesses enraizados na colônia, fortalecendo-o politicamente de tal sorte que aos governadores das capitanias, cujos poderes eram sempre transitórios, não restava alternativa que não fosse uma convivência administrativa harmoniosa, sem que houvesse interferência nas ações do Secretário ${ }^{209}$.

Apesar das ameaças de renunciar ao ofício em razão do prejuízo que tivera com a transferência da sede do Vice-Reinado, José Pires de Carvalho e Albuquerque pagou duas vezes pela vitaliciedade do ofício porque, como demonstra Pedro Puntoni, ser Secretário de Estado significava ser a pessoa que dava efetividade na colônia das decisões tomadas pelas autoridades régias nos dois lados do Atlântico. O Secretário de Estado era homem de confiança do governador, seu primeiro oficial de despacho, que era consultado em questões pequenas e grandes de Estado, uma vez que ficava aos seus cuidados o arquivo cartorial da jurisdição da Capitania da Bahia, sede do vice-reinado até $1763^{210}$.

Segundo Rodolfo Garcia, entre os funcionários mais graduados da colônia estava o Secretário de Estado, cargo criado em 1646 e dado a Bernardo Vieira Ravasco, irmão do Padre Antônio Vieira, a princípio trienal e, depois de 1650, sem limitação de tempo. Em 1663, foi permitido a Ravasco que, por sua morte, sucedesse-lhe no ofício seu filho Gonçalo Ravasco Cavalcanti de Albuquerque ${ }^{211}$. A envergadura política do cargo justifica o esforço que José Pires de Carvalho e Albuquerque fizera para torná-lo, inclusive, hereditário, como de fato aconteceu. Em 7 de maio de 1779, depois do falecimento de seu pai de mesmo nome e da desistência do ofício por seu irmão primogênito, José Pires de Carvalho e Albuquerque teve a propriedade da vitaliciedade do ofício arrematado duas vezes por seu pai confirmada por Carta Régia, com a denominação de "Secretário de Estado do Brasil para elle e seus sucessores gozarem

\footnotetext{
208 Ibidem.

209 A respeito da relevância da Secretária de Estado do Brasil, ler: Pedro Puntoni. Bernardo Vieira Ravasco, secretário do Estado do Brasil: poder e elites na Bahia do século XVII. In: Modos de Governar: idéias e práticas políticas no Império Português, séculos XVI-XIX. São Paulo: Alameda, 2005.

${ }^{210}$ Idem, p. 173.

${ }^{211}$ Cf. Rodolfo Garcia, op.cit., p. 59.
} 
na forma do Direito Consuetudinário do Reino com faculdade de nomear Serventuários nos seus impedimentos $[\ldots]^{, 212}$.

A prerrogativa da hereditariedade da vitaliciedade do ofício de Secretário de Estado do Brasil conferida à família de José Pires de Carvalho e Albuquerque, bem como a mudança de sua nomenclatura, ocorreu apenas na Bahia no final do século XVIII $^{213}$, confirmando a centralidade política do Secretário de Estado na administração local e, como se terá oportunidade de demonstrar, nos mais variados assuntos da coroa portuguesa. A partir da alteração da nomenclatura do ofício de sua propriedade, José Pires de Carvalho e Albuquerque teve seu poder constantemente ampliado. Em 9 de setembro de 1782, o então governador da capitania da Bahia, d. Rodrigo José de Menezes, escreveu um ofício para Martinho de Mello e Castro participando-lhe da nomeação de José Pires de Carvalho e Albuquerque para exercer interinamente a Provedoria da Alfândega, a Intendência da Marinha e Vedoria Geral do Exército, por ter adoecido Antônio José de Sousa Freire ${ }^{214}$.

Em 1786, José Pires de Carvalho e Albuquerque solicitou, à S. M., a exclusividade em descascar o arroz em sua propriedade, na Quinta do Unhão, atual Museu de Arte Moderna da Bahia, que ficava no centro da cidade-baixa, de "porta para o mar", vizinha da Alfândega e da Ribeira, e próximo ao Ancoradouro dos Navios ${ }^{215}$, sob o argumento de que "com Despesa de minha Fazenda procuro promover a cultura deste gênero e sua factura, pelo zelo patriótico que me assiste "216. Em 11 de maio de 1786, o então governador da capitania da Bahia, d. Rodrigo José de Menezes, encaminhou uma representação na qual argumentava que:

"o privilégio exclusivo de descascar o arroz em Engenho de Agoa e Bestas, que pretende fazer no Sítio de sua Quinta do Unhão a borda'ágoa e dentre desta Cidade, se não pode duvidar a grande vitalidade que resultará a nossa Capital do Reino, e aumento da Agricultura deste gênero, que o anno

\footnotetext{
${ }^{212}$ APEB, Judiciário, Inventário de José Pires de Carvalho e Albuquerque, 1808/01/97/141/02, folhas $124,124 \mathrm{v}$. Grifos meus.

${ }^{213}$ Não há estudos monográficos que comprovem a existência do cargo de Secretário de Estado além das capitanias da Bahia, Rio de Janeiro e Minas Gerais como afirma Rodolfo Garcia. Diferentemente da nomenclatura e da centralidade do cargo de José Pires de Carvalho e Albuquerque na capitania da Bahia, no final do século XVIII, para os propósitos desta tese, cumpre destacar que Laura de Mello e Souza demonstra que Cláudio Manuel da Costa foi nomeado por certidão de 9 de março de 1763 a ocupar o cargo de "Secretário de Governo" na capitania das Minas Gerais. Cf. Rodolfo Garcia, op.cit.; Laura de Mello e Souza. Cláudio Manuel da Costa. São Paulo: Companhia das Letras, 2011, capítulo 12, pp. 95103.

${ }^{214}$ AHU_CU_CA, Baía, doc. 11133. Chamo atenção para a centralidade desses cargos na administração local.

${ }^{215}$ AHU_CU_CA_Cx. 63, doc. 12143.

${ }^{216}$ AHU_CU_CA_Cx. 63, doc. 12144.
} 
passado chegou a produzir a Comarca de Ilheos quarenta mil Alqueires de Arroz, e este anno produzirá muito maior número, sendo animado pelo pretendente que por seo procedimento e excessivo exercício que tem no Real Serviço, se faz digno de Graça" 217 .

Após obter o privilégio exclusivo de descascar o arroz em sua propriedade, no ano seguinte, o Secretário escreveu à S. M., sobre os inconvenientes na mudança do Tribunal da Mesa de Inspeção e Arrecadação do Tabaco, situados em sua propriedade há mais de um século, para o Trapiche do Bernabé, de propriedade de Teodósio Gonçalves Silva ${ }^{218}$. Quem interveio a favor do Secretário de Estado foi o então governador d. Rodrigo José de Menezes, informando a Martinho de Mello e Castro que há mais de um século a família de José Pires de Carvalho e Albuquerque obtinha o direito exclusivo da arrecadação do Tabaco em sua propriedade, que era:

"a maior das que há no centro da Cidade Baixa, erigida por seos avós com aprovaçam Régia em Morgado, e que o tenue rendimento delle e do Trapiche do Açúcar, que tem na mesma propriedade, hé que subsiste a família do suplicante, que sendo das da primeira nobreza dessa Capitania, sempre se destinguio no Real Serviço com bom comportamento, actividade, desinteresse e obediência das Leys, como hé constante, e eu o exprimento, ocupando por si e seos progenitores os primeiros Postos e Cargos da República, sem fama en contrário",219.

$\mathrm{O}$ argumento do governador d. Rodrigo José de Menezes era que a permanência da Mesa de Inspeção e a Arrecadação do Tabaco na propriedade de José Pires de Carvalho e Albuquerque seria o melhor meio de "conservação da nobreza", que não deveria ter prejuízo com a mudança para o Trapiche de "hum particular" que era "rico pelas suas interessantes negociacoens, com o motivo de afectadas ideas de utilidade pública $[\ldots]^{220}$.

Além da defesa do governador, José Pires de Carvalho e Albuquerque contou com o apoio de boa parte dos negociantes e do primeiro escrivão da Mesa de Inspeção, Manoel Rodrigues Barreto, que juntos escreveram uma representação para a coroa portuguesa valendo-se de uma Certidão no livro segundo do Regimento de Provisões e Ordens Régias, de 1770, solicitando a permanência da Mesa de Inspeção e a

\footnotetext{
${ }^{217}$ Idem. Grifo meu.

${ }^{218}$ AHU_CU_CA_Cx.66, doc. 12701.

219 Idem.

${ }^{220}$ Ibidem.
} 
Arrecadação do Tabaco na propriedade do Secretário de Estado por estar em melhor localização para os negociantes e barqueiros que nelas sempre foram atendidos com muito "zelo e ligeireza". Entre os que assinaram a Representação estavam Francisco Vicente Viana, filho de Frutuoso Vicente Viana, e Adriano de Araújo Braga, administrador do Celeiro Público durante o período de 1796 e $1800^{221}$.

Parece evidente que o Secretário de Estado valeu-se do conhecimento da memória do Estado que seu cargo lhe conferia para benefício próprio e reafirmação do seu poder na capitania da Bahia ${ }^{222}$. Tanto mais que no final de seu governo, em 3 de janeiro de 1788, d. Rodrigo José de Menezes manifestou seu apreço ao Secretário, escrevendo uma “attestação" 223 , com cópia para o seu sucessor, afirmando que àquela altura José Pires de Carvalho e Albuquerque "servia nos empregos" de Secretário de Estado e Governo do Brasil; de Intendente da Marinha e Armazéns Reais; Vedor Geral do Exército; Provedor e Ouvidor da Alfândega da Bahia; e Deputado da Junta da Real Fazenda.

Assim, quando d. Fernando José de Portugal e Castro assumiu o governo da capitania da Bahia, logo percebeu a influência política do Secretário de Estado, que havia assinado pela permanência de seu antecessor no governo da capitania. Dias depois de sua posse, o governador foi comunicado por Provisão Régia que se praticasse com o Secretário de Estado, José Pires de Carvalho e Albuquerque, as mesmas continências militares que se observavam com o Secretário de Estado de Goa, sem modificação, interpretação ou diminuição alguma, pois de acordo com uma petição encaminhada pelo próprio Secretário, ele não era "de inferior condição à elle, tanto pela sua qualidade, como pello grande Donativo de Cento e Vinte e Quatro mil cruzados, que por elle deu à Real Fazenda de Sua Magestade [.... $]^{224}$.

Em razão dos empréstimos gratuitos feitos por sua família à coroa portuguesa, o próprio José Pires de Carvalho e Albuquerque solicitou que:

"Vossa Magestade seja servida mandar passar Provisão ao Governador da Capitania da Bahia, para que com o Suplicante se pratiquem as mesmas Continências Militares

\footnotetext{
${ }^{221}$ AHU_CU_CA_Cx. 66, doc. 12703 e doc. 12704.

222 AHU-Bahia, cx. 2, doc. 110; AHU_ACL_CU_005, Cx. 2, doc. 189. "Certidão de José Pires de Carvalho e Albuquerque atestando o registo da ordem que determina a importância do secretário do estado e guerra na hierarquia administrativa do Brasil. Bahia, 24 de julho de 1676".

223 AHU_ACL_CU_005, Cx. 210, doc. 14878: Papéis de Serviço do Capitão-Mor das Ordenanças da cidade da Bahia e Secretário de Estado e Guerra do Brasil, José Pires de Carvalho e Albuquerque, para fins de justificação. In: Inventário Castro e Almeida.

${ }^{224}$ AHU_CU_CA_Cx. 71, doc. 13557.
} 
que se observão com o Secretário de Estado de Goa, sem modificação, interpretação ou diminuição alguma, na forma que se mostra pellas referidas attestaçoens, em observância das mesmas Reaes Ordens com que Vossa Magestade tem authorizado e distinguido este emprego, mercê em que não he lesada a Real Fazenda de Sua Magestade, nem a Sua Real Coroa ${ }^{225}$.

Assim como seu antecessor, d. Fernando José de Portugal e Castro não se indispôs com José Pires de Carvalho e Albuquerque. Aliás, muito ao contrário, pois os vários conflitos surgidos na capitania da Bahia e nos territórios sob sua jurisdição, nos últimos anos do século XVIII, foram solucionados pelo governador com a ajuda do Secretário de Estado do Brasil. O fato é que a proximidade do governador da capitania da Bahia com o responsável pela memória cartorial do Estado, que tinha sido sede do governo até 1763, fez com que d. Fernando José de Portugal e Castro fosse chamado a emitir parecer sobre vários assuntos que não eram de sua alçada administrativa, mas do Vice-Rei.

Além disso, as cartas trocadas entre o Vice-Reinado do Rio de Janeiro e o governador general da capitania da Bahia, d. Fernando José de Portugal e Castro, demonstram que de fato Arno Wehling acerta ao observar que na prática o ViceReinado nunca exerceu autoridade efetiva sobre a Bahia e as capitanias do norte. Em carta de 12 de março de 1796, o Conde de Rezende afirmava:

"supus mentirosa a notícia que aqui corria de se achar a Bahia com grande falta de mantimentos, porque $V$. Exa., nunca me lembrou a socorresse. Agora vejo verificada pela sua Carta a esterelidade para a diminuir vão essas embarcaçoens, que ainda dirigindo-se a outros Portos, buscão esse. A Câmara desta Cidade muito recomendey auxiliasse este importante negócio na parte que lhe toca, guardando sempre as suas medidas a respeito da preferência que deve ter este povo, ao que V. Exa. governa: Estimarei muito que as minhas diligências evitem em parte os dannos que V. Exa., receia ao Serviço de Sua Magestade, que hé o objecto que na presente ocasião e em todas as mais me obriga a trabalhar com tão poucas forças e com tão pouca saúde ${ }^{, 226}$.

Ao reconhecer a relevância do porto da Bahia e o fato de o governador da capitania nunca ter solicitado ajuda do Vice-Rei, o Conde de Rezende sugere o que ocorria com bastante frequência naquela última década do século XVIII: a capitania da

\footnotetext{
${ }^{225}$ Idem, com atestações dos documentos de $\mathrm{n}^{\mathrm{o}} 13558$ e 13559.

${ }^{226}$ APEB, Colonial, Cartas do Governo, Vice-Rei do Estado do Brasil, Maço 200, doc. 14. Grifo meu.
} 
Bahia não pedia ajuda porque era solicitada por questões políticas e econômicas pelos governadores de outras capitanias que não estavam sob sua jurisdição e pelas autoridades de territórios sob sua jurisdição: como Angola, Daomé, Benguela e, sobretudo, as ilhas de São Tomé e Príncipe. As cartas enviadas do Brasil ao governador de Angola, d. Miguel Antônio de Mello, Conde de Murça, durante o período de 1797 e 1800, são importantes nesse sentido.

Em 22 de outubro de 1799, o governador da Bahia, d. Fernando José de Portugal e Castro, enviou uma carta ao governador de Angola na qual comentava as hostilidades que um corsário francês tinha praticado naquela costa africana, aprisionando algumas embarcações da Bahia e do Rio de Janeiro. Depois de comunicar a "falta de meios" que a Bahia se encontrava para socorrer Angola dos ataques dos corsários, d. Fernando despediu-se afirmando:

"como brevemente parte Embarcação para aquella Capital [Rio de Janeiro], por ella remetterei os sobreditos Offícios de $V$. Ex $x^{a}$., depois de os fazer copiar vista a attenção que V. Ex $x^{a}$. commigo pratica de mos remetter abertos o Sello volante para este fim, desejando que V. Exa. consiga os socorros de que necessita, o que será difficultozo nas circunstancias prezentes, por se acharem naquelle Porto duas Naos, e dous Bergantins, que são poucos para os Comboys que se deve dar annualmente, a fim de proteger os Navios do Commércio do Rio de Janeiro, Bahia e Pernambuco [...] ${ }^{, 227}$.

Não era usual que os governadores enviassem cartas com os selos abertos, pois qualquer pessoa podia ter acesso ao teor das informações escritas, muitas vezes "secretíssimo", das correspondências trocadas entre as autoridades régias ${ }^{228}$. No entanto, tal prática foi vulgarizada na correspondência que Miguel Antônio de Mello, governador de Angola na última década do século XVIII, enviava para o Conde de Rezende, pois além de ele saber que as embarcações paravam no porto da Bahia para descarregarem mercadorias e correspondências antes de seguirem para o Rio de Janeiro, deixar suas correspondências com os selos abertos era uma maneira de pedir ajuda ao

\footnotetext{
${ }^{227}$ BN, Sessão de Manuscritos, 22, 2, 49: Cartas do Brasil ao Governador de Angola D. Miguel Antônio de Mello (1797-1800), p. 18, 18v. Grifo meu.

${ }^{228}$ Marilia Nogueira dos Santos. Escrevendo cartas, governando o império. A correspondência de Antônio Luís Gonçalves da Câmara Coutinho no governo do Estado do Brasil. Niterói: Programa de PósGraduação em História da Universidade Federal Fluminense, 2007. Dissertação de Mestrado.
} 
governador da Bahia, reconhecendo a centralidade da autoridade política do governador da Bahia naquele final de século ${ }^{229}$.

Esse tipo de "atenção" ao governador da Bahia, d. Fernando José de Portugal e Castro, apesar de proibida entre dos governadores, não era desconhecida das autoridades de Lisboa, cujas correspondências davam margens a esse tipo de situação. Nas correspondências com as providências administrativas, políticas e econômicas expedidas por ordem do príncipe regente para o Vice-Rei, entre o período de 1796 e 1800, chama atenção o fato de que a maioria das ordens régias expedidas contivesse a denominação "Vice-Rei do Rio de Janeiro" e não "Vice-Rei do Estado do Brasil”, cujo número de correspondência com tal denominação é muito pequeno ${ }^{230}$.

Além disso, as várias correspondências trocadas entre as autoridades de Lisboa, o governador da Bahia e o Vice-Rei do Rio de Janeiro demonstram haver uma espécie de centralidade política compartilhada, em que o parecer de d. Fernando José de Portugal e Castro foi determinante para que a coroa portuguesa "repensasse" certas posturas "a bem das circunstâncias".

É o caso da venda de produtos da terra e a proibição da venda de produtos trazidos pelos navios estrangeiros arribados nos portos do Brasil, especialmente no do Rio de Janeiro, de Pernambuco e da Bahia, conforme o Alvará de 5 de outubro de 1715. A esse respeito, d. Fernando José de Portugal e Castro, fundamentando-se nos ofícios e ordens régias da Secretaria de Estado, comentou que era usual que tais despesas das arribadas fossem pagas em dinheiro ou "em letras seguras", e somente na falta desses recursos que se deveria aceitar a carga ou parte dela para enviá-la para Lisboa ${ }^{231}$ procedimento que os Vice-Reis do Rio de Janeiro não cumpriam.

Em 1798, no entanto, diante do aumento de embarcações que faziam arribadas no porto da Bahia, d. Fernando José de Portugal e Castro foi comunicado que a proibição continuava, exceto dos produtos necessários ao pronto pagamento das despesas realizadas. D. Fernando solicitou que a coroa fornecesse "ordem mais

\footnotetext{
229 Demonstrar-se-á adiante que àquela altura d. Fernando José de Portugal e Castro já tinha sido designado por provisão régia secreta para fazer comentários dos regimentos dos governadores gerais. Tarefa que provavelmente d. Miguel Antônio de Mello já sabia, de modo que enviar correspondências com os selos abertos para que d. Fernando anotasse o teor das informações era também uma maneira de auxiliá-lo na tarefa.

${ }^{230}$ BN, Sessão de Manuscritos, 06, 3,009: Coleção cronológica e analítica em que se compreendem todas as providências administrativas, políticas e econômicas que se expediram ao vice-rei do Estado do Brasil por ordem do príncipe regente, 1796-1800.

${ }^{231}$ Fernando José de Portugal e Castro. Comentários ao Regimento de Roque da Costa Barreto. In: Marcos Carneiro de Mendonça. Raízes da Formação administrativa do Brasil. Rio de Janeiro: IHGB/CFC, 1972, vol. 2, p. 827.
} 
positiva" a respeito, pois o Alvará de 1715 era diametralmente oposto ao Aviso de 4 de junho de 1798. Assim, a Bahia em 8 de março de 1799 e o Rio de Janeiro em 20 de março de 1800, quase um ano depois, foram autorizadas por cartas régias a praticarem o que o governador da Bahia havia prescrito, com a ressalva de que os direitos pagos a Real Fazenda seriam duplos com a saída de Lisboa e a entrada nos portos da Bahia ou do Rio de Janeiro ${ }^{232}$.

Um ano depois, tais determinações foram anuladas, voltando a vigorar o Alvará de 1715 e a Provisão em forma de lei de 8 de fevereiro de $1711^{233}$. A coroa portuguesa resolveu recrudescer as regras que os governadores deveriam adotar com os navios estrangeiros em razão das constantes denúncias de prática de contrabando e descaminhos que ocorriam nos portos do Brasil, sobretudo no porto da Bahia e do Rio de Janeiro. Em 1799, por exemplo, d. Rodrigo de Sousa Coutinho mandou uma extensa carta a d. Fernando José de Portugal e Castro, solicitando providências urgentes sobre o contrabando de fazendas por navios ingleses na capitania da Bahia e do Rio de Janeiro, de acordo com as constantes queixas e denúncias dos comerciantes portugueses. Segundo d. Rodrigo:

"a grande desordem e abuso com que no Porto da Bahia e do Rio de Janeiro se está arruinando todos os dias o Comércio Português, por Embarcações Estrangeiras, que com falsos e figurados pretextos arribão àquelles Portos carregados de fazendas com o destino de alli se venderem, como tem sucedido seguindo-se huma total ruina ao Comércio Nacional, se se não ocorrer já com o necessário remédio ${ }^{, 234}$.

De acordo com a denúncia, no ano de 1797 entraram no porto da Bahia nove navios ingleses carregados de fazendas, que foram vendidas:

"por menos de 40 e 50 por cento do que as facturas que forão daqui remettidas com gravíssimo prejuízo dos Direitos Reaes, e dos Vassalos Portugueses, que não podem competir nessas vendas com os Estrangeiros em razão dos direitos que aqui se pagão e dos mais que pagão no Brasil "235.

\footnotetext{
${ }^{232}$ Cf. Arno Wehling, op.cit., p. 81.

233 Fernando José de Portugal e Castro. Comentários ao Regimento de Roque da Costa Barreto. In: Marcos Carneiro de Mendonça. Raízes da Formação administrativa do Brasil. Rio de Janeiro: IHGB/CFC, 1972, vol. 2, p. 830.

${ }^{234}$ AHU_CU_CA_Cx. 99, doc. 19378.

${ }^{235}$ Idem.
} 
O mesmo aconteceu no porto do Rio de Janeiro, em 1798, com a entrada de 11 navios ingleses que venderam suas fazendas à luz do dia e com o conhecimento das autoridades locais. Em ofício de 28 de janeiro de 1799, d. Fernando respondeu ao Ministro que era de se admirar que S. M. ainda se preocupasse com a falsidade das queixas dos comerciantes de Lisboa sobre o abuso e prevaricação das autoridades da capitania da Bahia em relação à venda de fazendas estrangeiras por contrabando, depois das "severas e estreitas ordens dadas a este respeito" "236.

D. Fernando argumentou que d. Rodrigo deveria chamar os comerciantes que fizeram a denúncia para eles dizerem os nomes dos navios ingleses que eles afirmavam, sem conhecimento de causa, terem entrando no porto da Bahia. Isso porque, segundo o governador da Bahia, grande parte dos contrabandos era praticado pelos próprios comerciantes de Lisboa "em os próprios Navios Portugueses, como he público e constante, não sendo huma nem duas as Lanxas e Barcos, que fora da Barra de Lisboa transportar o contrabando para bordo ${ }^{, 237}$.

D. Fernando José de Portugal e Castro prosseguiu sua resposta confrontando as determinações de d. Rodrigo de Sousa Coutinho sobre as providências que ele mandava praticar para se evitar a todo custo o contrabando de navios estrangeiros nos portos da Bahia e do Rio de Janeiro. Para o governador da Bahia:

"como he possível que no caso de água aberta, se conceda sempre no espaço de três dias, quando às vezes nem basta o de três meses, sendo preciso descarregar a embarcação, se assim se declara no Termo de vestoria a que se procede, alem de que muitas vezes a estação não da lugar a fazer-se a vela em tão breve espaço? ${ }^{238, "}$

Além disso:

"como se hão de fixar as escolhidas pondo-se lhes cadeados, se as Leys não ordenão semelhante providência; e como se há de prohibir que indivíduo algum venha a terra, quando o Capitão da Embarcação necessita de falar já com o Governador, já com o Intendente da Marinha, já com algum comerciante para lhe assistir quando não trás dinheiro, afim de se apresentar e de se comprar os Gêneros de que necessita? 239 ,"

\footnotetext{
${ }^{236}$ AHU_CU_CA_Cx. 99, doc. 19377.

237 Idem.

238 Ibidem

${ }^{239}$ Idem, Ibidem
} 
No arrazoado de d. Fernando José de Portugal e Castro, o contrabando dos navios estrangeiros nos portos brasileiros, por mais severas que fossem as leis que o proibissem, era inevitável, pois nenhuma nação proibia o desembarque em terra do Capitão ou de pessoas da tripulação dos navios de nações amigas e aliadas para que eles obtivessem o que fosse preciso para seguir viagem. Além disso, a providência de se acompanhar os navios estrangeiros na saída dos portos citados por embarcações brasileiras requeria uma fragata ou um bergantim de Guerra destinado exclusivamente para esse fim, mas, ainda assim, tais embarcações brasileiras poderiam perfeitamente sair do controle do porto da Barra para encontrar-se com embarcações vindas da Costa da Mina, de Lisboa e do Porto para praticarem contrabando sem que as autoridades soubessem $^{240}$.

A questão da resposta de d. Fernando José de Portugal e Castro era que além de tais medidas não combaterem o contrabando, eram dispendiosas para uma Real Fazenda tão necessitada de empréstimos. Assim, d. Fernando concluiu ser "sumamente dificultoso em toda a parte cohibi-lo [contrabando] totalmente”, aproveitou para afirmar que:

"nada me aborrece, nem me incomoda mais do que a entrada neste Porto de qualquer Navio desta natureza, pelo desejo que tenho de fazer observar as ordens da Mesma Senhora, e pelas impertinências e incivilidades que as vezes se sofrem aos Estrangeiros, com quem se não pode sempre usar de todo aquele rigor que se poderia praticar com os Mestres das Embarcaçoens Portuguesas, para evitar queixas e representaçoens de que as vezes resulta comprometerem-se as Cortes, muito mais recomendando-se-me que os trate com polidez, sem groçaria ou não tratamento, como o tenho praticado" ${ }^{241}$.

Parece claro que, nesse caso, d. Fernando José de Portugal e Castro questionou e refutou as reivindicações dos comerciantes de Lisboa e as diretrizes de d. Rodrigo de

\footnotetext{
${ }^{240} \mathrm{O}$ arrazoado do governador da capitania da Bahia sobre as vantagens que Portugal poderia obter no comércio ilegal com os espanhóis reflete as proposições acerca do comércio ilegal tolerável de Ernest Pijning: "Embora as autoridades portuguesas protestassem contra o comércio ilegal em seu território, incentivavam as transações comerciais ilegais entre Portugal e a América espanhola. O comércio com os territórios hispânicos através da Colônia do Sacramento era considerado positivo, pois trazia prata. Além disso, por meio de uma ocupação virtual e econômica, tanto os legisladores portugueses quanto os espanhóis buscavam obter a posse das terras disputadas. Em outras palavras, os portugueses e outros homens de Estado viam o contrabando com bons olhos desde que este atendesse aos interesses econômicos e políticos de sua terra natal". Cf. Ernst Pijning. Contrabando, ilegalidade e medidas políticas no Rio de Janeiro do século XVIII. Revista Brasileira de História. São Paulo, v. 21, nº42, 2001, pp. 397-414.

${ }^{241}$ AHU_CU_CA_Cx. 99, doc. 19377.
} 
Sousa Coutinho, em uma quase defesa ao comércio com as nações estrangeiras amigas. O governador da Bahia, de fato, achava que o comércio com as nações estrangeiras, especialmente com os americanos e ingleses, era muito prejudicial ao comércio "nacional", porém:

"a negociação clandestina e disfarçada, que fazem os espanhóis de Monte Vidio e Bueno Aires com as nossas colônias, nos é sumamente vantajoso e mais interessante a Portugal do que a Espanha. Eles exportam do Brasil bastantes fazendas da Europa, e até as de contrabando que, uma vez introduzidas, é conveniente dar-lhes semelhante saída, aguardente, algum açúcar, e escravos, e importam principalmente prata e couros, e também alguma carne seca e sebo, de sorte que para saldarem e equilibrarem a sua importação, com a exportação, se vêm obrigados a deixarem anualmente uma grande quantidade de patacas, ${ }^{, 242}$.

Mesmo sabendo que o couro era um dos principais produtos de exportação do Rio Grande de São Pedro, d. Fernando José de Portugal e Castro achava que a quantidade de couro introduzida na Bahia e no Rio de Janeiro pelos espanhóis tinha mais utilidade do que prejuízo ao comércio, pois além de o couro poder ser redistribuído para a Europa, a capitania podia se beneficiar com a introdução de patacas que, a seu ver, eram muito necessárias naquele momento de sangria das finanças régias. Além disso, apesar da proibição da venda de escravos a outras nações estrangeiras pelo Alvará de 14 de outubro de 1751, d. Fernando via enorme vantagem que as capitanias da Bahia e do Rio e Janeiro praticassem esse comércio com os espanhóis, porque eles não tinham o tabaco necessário para a compra de cativos na Costa da África ${ }^{243}$.

Evidentemente que tais argumentos contrariavam as ordens de d. Rodrigo de Sousa Coutinho, algumas das quais não cumpridas pelo governador da Bahia, pois muitas delas "nem sempre vêm determinadas por Carta Régia; mas por ofícios do Secretário de Estado, as quais faço consultar na Junta"244. Por ora, importa ressaltar que D. Fernando José de Portugal e Castro parece ter tirado muita vantagem de sua proximidade com a memória cartorial do Estado, franqueada pelo Secretário de Estado e Governo do Brasil, José Pires de Carvalho e Albuquerque, e pelo fato de a coroa

\footnotetext{
${ }^{242}$ Cf. Fernando José de Portugal e Castro. Comentários ao Regimento de Roque da Costa Barreto. In: Marcos Carneiro de Mendonça. Raízes da Formação administrativa do Brasil. Rio de Janeiro: IHGB/CFC, 1972, vol. 2, p. 834.

243 Idem, p. 835.

244 Idem, p. 798.
} 
portuguesa ter a prática de sobrepor provisões, ordens régias, alvarás ao sabor de distintas conjunturas.

Não parece exagerado afirmar que essa proximidade política entre o Secretário de Estado e o governador da capitania da Bahia - com sucessivas demonstrações de amplo conhecimento acerca dos regimentos e das práticas coloniais -,tenha sido determinante para que d. Fernando José de Portugal e Castro fosse designado, por Provisão Régia expedida pelo Conselho Ultramarino em 29 de julho de 1796, a fazer a revisão e o comentário de todos os Regimentos dos governadores do Brasil e remeter ao Conselho Ultramarino:

"huma cópia do Regimento ou Regimentos da vossa respectiva Capitania, como todas as ordens que os tenha observado, ampliado, ou restringido, practicando-o assim uma circunstanciada informação e parecer sobre cada hum dos seus antigos [procedimentos] practicáveis ou impracticáveis em benefício do Real Serviço e dos Casos [...] que por lhe a vista das ordens e dos mais que o correr, se por ao formalizar de novo ou [alterar] e corrigir os antigos Regimentos que existem nessa Capitania, procedendo-se a outros que se acomodem e tenhão uso segundo a vicicitude dos tempos "245.

Designado para a importante tarefa de, ao fim e ao cabo, fazer um balanço da colonização portuguesa no Brasil, no final do século XVIII, que serviria para a elaboração do primeiro Regimento do Vice-Reinado, a partir da primeira década do século XIX, d. Fernando só conseguiu concluir essa tarefa em razão da proximidade com o Secretário de Estado, José Pires de Carvalho e Albuquerque, que lhe franqueava constantemente os documentos arquivados na Secretaria de Estado e Governo do Brasil, que ficava na Bahia. A tarefa foi concluída apenas em $1804^{246}$, mas não parece exagerado supor que o governador general da capitania da Bahia sabia, desde 1796, que a elaboração dos comentários do regimento de Roque da Costa Barreto e o encaminhamento de vários conflitos deflagrados naquele tumultuado fim de século eram cruciais para a salvaguarda do poder colonial no Brasil e para a sua própria carreira.

\footnotetext{
${ }^{245}$ BN, Divisão de Manuscritos, Fundo Marquês de Aguiar, doc. 1, 4, 7 de 30 de julho de 1796.

246 BN, Divisão de Manuscritos, Fundo Marquês de Aguiar, doc. 9, 2, 26 de 10 de maio de 1804. "Regimento dos Governadores Gerais do Brasil com as observações do Ilmo. Sr. Vice-Rei Dom Fernando José de Portugal e Castro". A transcrição desse documento está em Marcos Carneiro de Mendonça. Raízes da formação administrativa do Brasil. Rio de Janeiro: IHGB/Conselho Federal de Cultura, 1972, Vols. I e II.
} 
Até porque, no mesmo ano de 1796, d. Fernando José de Portugal e Castro, e não o Vice-Rei do Rio de Janeiro, foi incumbido por outra Provisão Régia de 11 de setembro a fazer:

"hum exame circunstanciado de diferentes objectos nella ajuntada para reconhecer melhor o estado Físico e Político dos Domínios Ultramarinos, remettendo todas as informações que poder haver ou em Relacoens circunstanciadas, ou em Mappas individuados de cada hum dos mesmos objectos e exportação em virtude da ordem que assima fiz menção (me) resolvi a remettê-la na inteligência de que por ella pode $V$. Exa., no reconhecimento de que deseja saber nesta matéria" ${ }^{, 47}$.

Os diferentes objetos mencionados na Provisão Régia diziam respeito, sobretudo, ao funcionamento da administração e da política nas possessões portuguesas ultramarinas, não apenas na colônia americana. Dessa feita, tudo leva a crer que o modo pelo qual d. Fernando José de Portugal e Castro governava a Bahia e interferia em assuntos que não eram de sua jurisdição foram determinantes para designá-lo a fazer um diagnóstico detalhado da política e da economia das possessões do Império Português, em um momento de constante ameaça de invasão estrangeira.

Por tudo o que se viu, não parece exagerado afirmar que no último quartel do século XVIII a capitania da Bahia compartilhava o exercício da capitalidade sobre o território do Brasil com o Vice-Rei do Rio de Janeiro. Especialmente quando se considera que só se pode:

"falar de capitalidade na condição de este centro chegar a repercutir a sua influência num determinado espaço, ou seja, sobre um Estado, independentemente da configuração que este assuma. Há, portanto, a considerar uma vertente dinâmica, expressa na capacidade que o centro tem de estruturar $e$ estabelecer hierarquias no interior de um território e com ele sustentar ligações. Trata-se, afinal, de analisar a rede sobre a qual se realiza a articulação entre o centro e as suas periferias ${ }^{248}$.

Como se viu, a mudança da sede político-administrativa para o Rio de Janeiro não fez com que Salvador perdesse o status de abrigar o mais importante porto

\footnotetext{
${ }^{247}$ APEB, Colonial, Fundo Governo Geral/Governo da Capitania. Registro de Correspondência expedida para o Rei (1797-1799), Maço 138, doc. 219, folha 326 v. Grifo meu. Cumpre destacar que essa tarefa foi reafirmada por Carta Régia datada de 10 de maio de 1798.

${ }^{248}$ Catarina Madeira Santos. Goa é a chave de toda a Índia: Perfil Político da Capital do Estado da Índia (1505-1570), Lisboa: CNCDP, 1999, p. 23.
} 
comercial e político do Império Português no Brasil, sobretudo depois de seu vertiginoso crescimento econômico a partir das duas últimas décadas do século XVIII e de sua notável importância política nos assuntos do Império Português. Relevante notar, nesse sentido, a jurisprudência do Tribunal da Relação da Bahia sobre Angola e as Ilhas de São Tomé e Príncipe ${ }^{249}$, importante entreposto comercial da Coroa Portuguesa no Golfo de Guiné, que, como se terá oportunidade de demonstrar, terá um papel central para a política da coroa portuguesa no final do século XVIII ${ }^{250}$.

Além disso, o fortalecimento político de d. Fernando José de Portugal e Castro, em razão de sua aliança com o grupo controlado pelo Secretário de Estado e Governo do Brasil, fez com que ele também fosse consultado a respeito da criação de um Tribunal da Relação em Pernambuco, apesar das várias denúncias que chegavam ao Reino sobre os desmandos dos desembargadores do Tribunal da Relação da Bahia ${ }^{251}$. O governador da capitania da Bahia se opôs à criação de um Tribunal da Relação em Pernambuco, contrariando os interesses e o parecer favorável de Francisco de Sousa Coutinho, governador do Pará durante a última década do século XVIII e irmão de d. Rodrigo de Sousa Coutinho ${ }^{252}$.

Nesse sentido, se é verdade que o Rio de Janeiro manteve sua proeminência na defesa do território central e meridional da América ao longo do século XVIII ${ }^{253}$, do ponto de vista político e econômico, o Rio de Janeiro compartilhava o exercício da capitalidade com a capitania da Bahia que, sob o governo de d. Fernando José de Portugal e Castro, a partir de 1788, tornou-se um importante centro econômico e de decisão política cuja influência repercutiu em amplos territórios, alguns dos quais eram centrais para Portugal naquele contexto de constante ameaça de guerra entre as nações europeias.

Ademais, a centralidade do conhecimento e da experiência que a memória do Estado franqueada a d. Fernando José de Portugal e Castro e arquivada na Secretaria de

\footnotetext{
${ }^{249}$ Cf. Luís dos Santos Vilhena, op.cit., p. 298; Stuart B. Schwartz. Burocracia e sociedade no Brasil colonial: a Suprema Corte da Bahia e seus Juízes, 1609-1751. São Paulo: Perspectiva, 1979.

${ }^{250}$ Cf. Carlos Filomeno Azevedo Agostinho das Neves. S. Tomé e Príncipe na $2^{a}$. metade do século XVIII. Dissertação de Mestrado, Universidade Nova de Lisboa, 1988.

251 AHU-ACL-CU_005, Cx. 215, doc. 15113 "Carta do governador da Bahia [d. Fernando José de Portugal] à Rainha em resposta à provisão sobre a criação de um Tribunal da Relação na Capitania de Pernambuco, 2 de outubro de 1799”.

${ }^{252}$ BN, Sessão de Manuscritos, I-28, 25, 30. Relatório de Francisco de Sousa Coutinho, Governador de Pará, dirigido a D. Rodrigo de Sousa Coutinho, sobre a relação política entre Portugal e Brasil. Pará, 20 de setembro de 1797.

${ }^{253}$ Cf. Maria Fernanda Bicalho. O Rio de Janeiro no século XVIII: a transferência da capital e a construção do território centro-sul da América Portuguesa. Revista Urbana, Ano 1, nº 1, set/dez, 2006.
} 
Estado e Governo do Brasil, sob comando de José Pires de Carvalho e Albuquerque, possibilitou que o governador redimensionasse os elementos e o significado da capitalidade da capitania da Bahia no final do século XVIII, e a própria trajetória política de d. Fernando José de Portugal e Castro que, não à toa, é feito Vice-Rei em 1801, quando começou a sedimentar os fundamentos da capitalidade do Rio de Janeiro em relação às demais capitanias em $1808^{254}$.

${ }^{254}$ CU_CA_Cx. 116, doc. 22794. 


\subsection{Fernando José de Portugal e Castro e a corporação dos enteados}

D. Fernando José de Portugal e Castro nasceu em 4 de dezembro de 1752, em Lisboa. Era filho do 3. ${ }^{\circ}$ Marquês de Valença, d. José Miguel João de Portugal e Castro, e de d. Luísa de Lorena. Casou-se com d. Maria Francisca de Portugal e Castro, sem que o casal deixasse descendente. Após ter estudado na Universidade de Coimbra, seguiu a carreira da magistratura, servindo na Relação do Porto e na Casa da Suplicação. Em 1788, foi incumbido do governo da capitania-geral da Bahia, ao que se seguiu, em 1800, sua nomeação para o cargo de vice-rei do Estado do Brasil. Regressando a Portugal em 1807, é nomeado presidente do Conselho Ultramarino e conselheiro de Estado, mas se mantém no país por pouco tempo, pois em 1808 partiu para o Brasil com a família real ${ }^{255}$.

Já no Rio de Janeiro, é escolhido, em 7 de março de 1808, para três lugares importantes da governação: Ministro assistente ao Despacho, Ministro do Reino e Presidente do Real Erário. Nesse mesmo ano, em 17 de dezembro, foi feito conde de Aguiar, vindo a receber o título de Marquês do mesmo nome em 17 de dezembro de 1813. Até a sua morte foi encarregado das pastas da Guerra (a partir de 28 de janeiro de 1812) e dos Negócios Estrangeiros (a título efetivo, entre 28 de janeiro de 1812 e 26 de janeiro de 1814; a título interino, desde 26 de janeiro de 1814). Exerceu, também, os lugares de Presidente do Conselho da Fazenda e da Junta do Comércio, e de Provedor das obras da Casa Real. O Marquês de Aguiar veio a falecer na sexta-feira do dia 24 de janeiro de 1817, aos 64 anos, e, por ocasião do seu sepultamento na tarde do dia 25, em um carneiro da ordem de São Francisco de Paula ${ }^{256}$, o Cel. Maler, encarregado dos negócios da França no Brasil, escreveu a Luiz XVIII:

"depois de ter sido governador-general em Salvador, vice-rei no Rio de Janeiro durante 13 anos e $1^{\circ}$. Ministro durante 9, [o Marquês de Aguiar] morre sem deixar uma casa à viúva, nem mesmo um mobiliário decente e sei que se lhe não encontraram nem dinheiro necessário para as despesas do enterro. Tanta virtude e tão grande desinteresse seria muito belo em todos os países, mas no Brasil, Meu Senhor, é admirável e incrível $" 257$.

\footnotetext{
${ }^{255}$ Cf. Affonso Ruy. "O último governador da Bahia no século XVIII". Revista do Instituto Geográfico e Histórico da Bahia, 1944-1954, p. 126.

${ }^{256}$ Cf. Antônio José de Mello Moraes. "Chronica Geral do Brazil (1700-1800). Rio de Janeiro: B.L.Garnier Editor, 1886, Tomo Segundo, p. 166.

${ }^{257}$ Cf. Affonso Ruy, op. cit.
} 
Tanta virtude e desinteresse de d. Fernando José de Portugal e Castro também foram atestados, não sem ironia, por alguns de seus contemporâneos. Descrevendo as ações de todos os governadores da Bahia, Luís dos Santos Vilhena, professor régio de língua grega, conta-nos que D. Fernando José de Portugal e Castro aportou em Salvador, aos 35 anos de idade, em 17 de abril de 1788, na nau "Nossa Senhora de Belém”, em companhia do futuro governador das Minas Gerais, o Visconde de Barbacena, e do governador de São Paulo, d. Bernardo de Lorena. D. Fernando tomou posse do seu governo no dia seguinte ao da sua chegada, substituindo d. Rodrigo José de Menezes, considerado por Vilhena "mais empenhado e atento ao bom regime e ordem nos governos político, civil, econômico e militar" que seu sucessor ${ }^{258}$.

A razão para o juízo que o professor régio fizera do governador da Bahia era muito clara: na Bahia do final do século XVIII, "mais se receavam todos da taciturnidade do Sr. D. Rodrigo do que da alta e retumbante locução do Sr. D. Fernando em atual exercício do governo "259. Assim, executando as ordens de que vinha munido com demonstrações sistemáticas de austeridade, Vilhena afirma que "pouco tardou a natureza em demonstrar ser ela [austeridade] produção da arte", pois a seu ver, d. Fernando não "tinha as precisas forças para disfarçar a natural brandura e afabilidade de sua alma". Pouco tempo depois de assumir o governo da capitania da Bahia, d. Fernando José de Portugal e Castro reformou os auditórios, proibindo de advogar as pessoas que não fossem formadas e que se passavam por doutores sem terem frequentado Coimbra.

Em razão das ordens do governador, o Secretário de Estado e Governo do Brasil apresentou uma relação dos advogados que até aquele momento tinham apresentado documentos comprobatórios de suas formações para continuarem habilitados no exercício da advocacia. Do total de 28 advogados que atuavam na capitania da Bahia, na última década do século XVIII, 16 apresentaram documentos e os demais constavam na lista como "advogados por provisão" ou "advogado formado", que em ambos os casos significava falta de "habilitação" para a advocacia ${ }^{260}$.

\footnotetext{
${ }^{258}$ Luís dos Santos Vilhena. “A Bahia no século XVIII”. Salvador: Itapuã, 1969, vol. II, p. 423, passim. ${ }^{259}$ Idem, pp.423-424.

${ }^{260}$ APEB, Colonial, Correspondência recebida pelo Governador da Bahia pelo Chanceller da Relação (1782-1799), Maço 201-28, Cx. 80, doc. 10. Relação dos Advogados dos que em observância das Ordens do Ilmo. Exmo. Snr. Governador tem athé agora apresentado na Secretaria de Estado desta Capitania os seos Requerimentos, Cartas e Provisões e Documentos com que nos Auditórios desta Cidade exercitão o Ministério da Advocacia.
} 
Não obstante a falta de formação, de documentação e a ordem do governador, algumas pessoas continuaram advogando na capitania da Bahia. José Barbosa de Oliveira, inclusive, mesmo "advogando por provisão" ou justamente por isso, foi designado a ser o advogado de defesa dos indiciados no crime de sedição, deflagrado em 1798, que atualmente é conhecido por Conjuração Baiana de $1798^{261}$. Talvez seja por essa razão que Vilhena tenha afirmado que os advogados não se abalaram com a ordem de d. Fernando José de Portugal e Castro, pois apostaram na:

"natural brandura de ânimo do exmo. Governador, esperaram, e tão certo lhes saiu o seu cálculo, que conhecendo $S$. Excia. que não lhes restava outro modo de viverem, dentro em pouco tempo fechou os olhos, como dizem, e tolerou que requeressem e advogassem como dantes $" 262$.

Ocorre que durante o período em que Luís dos Santos Vilhena escrevia sobre o "viver em colônia" em suas cartas, d. Fernando José de Portugal e Castro recusou o pedido de algumas pessoas. Em 17 de maio de 1797, por exemplo, Joaquim José de Santa Anna, morador de Cachoeira, solicitou licença para advogar nos Auditórios da capitania da Bahia, porque se achava "munido de Provisão Junta" que devia ser "acreditável" pelo governador para que ele não tivesse prejuízo algum ${ }^{263}$. No parecer do Chanceler do Tribunal da Relação da Bahia, emitido ao governador em 2 de dezembro de 1799, Firmino de Magalhães Siqueira da Fonseca afirmou que o pedido de Joaquim José de Santa Anna não merecia atenção alguma, pois o suplicante não tinha qualidade para servir de Procurador do Número na Vila de Cachoeira porque não pode haver procuradores do No. naquellas Villas aonde há o estilo de Procurar sem Provisão a pessoa que for idonea e quiser ${ }^{, 264}$.

Tudo leva a crer que o parecer contrário do chanceler da Relação da Bahia ocorreu porque Joaquim José de Santa Anna foi um dos denunciantes do encontro no campo do dique do desterro ${ }^{265}$, marcado para a noite de 25 de agosto pelos partícipes da Conjuração Baiana de 1798, para que eles contassem o número de armas e iniciarem o

\footnotetext{
${ }^{261}$ Cf. ADCA.

${ }^{262}$ Idem, p.424.

${ }^{263}$ APEB, Colonial, Correspondência recebida pelo Governador da Bahia pelo Chanceller da Relação (1782-1799), Maço 201-28, Cx. 80, doc. 32.

${ }^{264}$ APEB, Correspondência recebida pelo governo da Bahia, Chanceller da Relação, 1782-1799, Maço: 201-28, Cx: 80, doc. 35. Chamo atenção para o fato de que o parecer do chanceler da Relação da Bahia foi emitido quase um mês depois do enforcamento e esquartejamento dos corpos dos réus da Conjuração Baiana de 1798.

${ }^{265}$ ADCA, vol. II, pp. 910-920. "Denúncia publica jurada e necessária que dá Joaquim Joze da Veiga, homem pardo, forro, cazado e official de ferrador [...]"; "Denúncia publica [...] que dá o Capitão do Regimento Auxiliar dos homens pretos Joaquim Joze de Santa Anna [...]”.
} 
levante ${ }^{266}$. Ocorre que, como se terá oportunidade de demonstrar adiante, as denúncias sobre o encontro marcado no Dique do Desterro deflagraram uma série de prisões e depoimentos que afirmavam que o encontro tinha sido projetado na casa do Secretário de Estado e Governo do Brasil, José Pires de Carvalho e Albuquerque ${ }^{267}$.

D. Fernando José de Portugal e Castro acatou o parecer do Chanceler da Relação da Bahia, contrariando os interesses de Joaquim de José de Santa Anna, que aproveitou que tinha sido condecorado com a Ordem de Cristo pela denúncia e solicitou que a coroa portuguesa intercedesse a seu favor e aumentasse o soldo que passou a receber com outra mercê, a promoção para Sargento-mor do Terceiro Regimento de Milícias da Bahia. Esse episódio foi efetivamente resolvido em 1801, com a coroa portuguesa negando o direito de José de Santa Anna de advogar nos Auditórios da capitania da Bahia e mantendo o valor do soldo. Pesou contra o suplicante um ofício de d. Fernando José de Portugal e Castro no qual afirmou:

"persuado-me que Sua Alteza attendeo bastantemente ao Suplicante por este motivo [denúncia], promovendo-o, como o promoveo, precedendo a minha Informação, ao Posto de Sargento-mor do Terceiro Regimento de Milícias desta Cidade, composto de homens pretos, em que a breve graduação e interesse por vencer vinte e seis mil réis de Soldo por mês, muito mais não tendo sido o Suplicante, como já expus a $V$. Exa., o primeiro verdadeiramente que fez sabedor a este Governo de similhante atentado, porem se Sua Alteza acha que esta remuneração ainda foi diminuta, pode deferir ao Suplicante como for Servido ${ }^{, 268}$.

Situação distinta ocorreu com Domingos da Silva Lisboa, requerente nos Auditórios da Relação da Bahia, que pediu a confirmação do seu ofício em 1792, cujo parecer do Chanceler da Relação da Bahia foi favorável ${ }^{269}$. Ocorre que Domingos da Silva Lisboa foi preso por suspeita de ter sido "o cabeça" do levante projetado em 1798 e autor dos "boletins manuscritos" afixados em prédios públicos da cidade, contendo as demandas políticas dos partícipes do levante. Domingos da Silva Lisboa permaneceu

\footnotetext{
${ }^{266}$ Cf. ADCA, vol. 1; AHU_CU_CA_Cx. 114, doc. 22552.

${ }^{267}$ É o caso do depoimento do escravo Jozé Felix da Costa. Cf. ADCA, pp. 925-928. "Testemunha de Jozé Felix da Costa, homem pardo escravo do Doutor Francisco Vicente Viana em cuja casa assistia ao tempo em que foi preso...".

${ }^{268}$ AHU_CU_CA_Cx. 114, doc. 22551. Ofício de 27 de abril de 1801.

${ }^{269}$ APEB, Colonial, Correspondência recebida pelo Governador da Bahia pelo Chanceller da Relação (1782-1799), Maço 201-28, Cx. 80, doc. 24. "Domingos da Silva Lisboa, ainda que dos mais modernos no exercício de Requerente, consta para informação que athé o presente pratica com mobilidade e sem notas $q^{\prime}$ o inhabilita para a (graça), a que pede a $V$. Ex $x^{a}$, lhe defira como lhe parecer justo. Bahia, 5 de fevereiro de 1792".
} 
encarcerado por mais de um ano ${ }^{270}$, e depois de ser inocentado das acusações, culpado por saber do levante projetado e não denunciá-lo às autoridades, saiu do Segredo da Relação e logo depois solicitou ao governador a confirmação de seu ofício, cujo parecer do Chanceler da Relação foi novamente favorável ${ }^{271}$. Assim, d. Fernando José de Portugal e Castrou pediu que a coroa portuguesa confirmasse o ofício de requerente nos Auditórios da Relação da Bahia para Domingos da Silva Lisboa por Provisão Régia, pelo que aconteceu em $1800^{272}$.

Essas atitudes de d. Fernando José de Portugal e Castro eram vistas por seus contemporâneos sem muita coerência, muitas vezes relacionadas ao seu caráter contemporizador com os grandes e brando com os "pequeninos" 273 . A brandura de ânimo do governador da Capitania da Bahia foi novamente atestada no breve e revelador comentário de Luís dos Santos Vilhena sobre a Conjuração Baiana de 1798.

Para o professor régio de língua grega, o levante projetado em 1798 relacionava-se à convulsão social causada por parte do corpo da tropa de milícias, à desordem administrativa e aos desmandos que alguns funcionários da administração local. Para Vilhena:

"[...] o corpo das tropas igualmente saiu dos limites da razão, falo dos soldados, por se verem livres da terra da Piedade, e lazareto a quem tinha mais respeito que a Angola e a Índia. Não se largaria talvez o fogo ao patíbulo público nem se fixariam nêle ludibriosos pasquins [diante da] contemporização porém de uns, a suma bondade de outros, e a rebuçada malignidade de alguns são em parte as causas dêstes e alguns outros procedimentos, o que não é de admirar em terras tão populosas como a Bahia, onde eles são inevitáveis ${ }^{274}$.

Apesar de ironizar o caráter contemporizador do governador da capitania da Bahia, Vilhena ressalta suas qualidades por ter conseguido:

"[...] o avultado empréstimo nacional com que esta praça

\footnotetext{
270 "Auto de exame, e combinação das Letras dos pesquins, e mais papeis sedicciozos, que apparecerão nas esquinas, ruas, e Igrejas desta Cidade que se achão incorporados na Devassa, que esta debaixo do N. 1 e do papel que elles estão escritos, com as letras de Domingos da Silva Lisboa nas peticoens, que forão achadas em sua caza, e com o papel limpo, que ahi tambem se achou, e tudo se acha junto ao auto da achada, e aprehensão constante do appenso N. 9". In: Autos da Devassa da Conspiração dos Alfaiates. Salvador: Imprensa Oficial do Estado, 1998, vol. 1, pp. 86-89. Doravante ADCA.

${ }^{271}$ APEB, Colonial, Correspondência recebida pelo Governador da Bahia pelo Chanceler da Relação (1782-1799), Maço 201-28, Cx. 80, doc. 35.

${ }_{272}$ APEB, Livro de Provisões Régias, No. 305 (1797-1801) folhas: 210 v, 211.

${ }^{273}$ Outra relação feita pelo P. Fr. Joze D'Monte Carmelo, religiozo carmelita descalço. Instituto Histórico e Geográfico Brasileiro, Notícia da Bahia, tomo IV, Lata 402, manuscrito 69. O documento está integralmente transcrito na obra de Luís Henrique Dias Tavares. História da Sedição intentada na Bahia em 1798 (A Conspiração dos Alfaiates). São Paulo/Brasília: Pioneira/INL, 1975, pp. 123-137, passim.

${ }^{274}$ Ibidem.
} 
concorreu para as urgências do Estado é devido a sua [d. Fernando José de Portugal e Castro] incansável diligência, e persuasão, bem como se deve à nímia perspicácia a pacificação dos malvados revoltosos que perfidamente haviam projetado a insubsistente sublevacão, e cruel massacre, produções tudo da ignorância, ociosidade, e embriaguez ${ }^{275}$.

Ainda que não tenha escrito nada a respeito, cumpre destacar a argúcia de Vilhena ao relacionar o empréstimo nacional à pacificação dos revoltosos de 1798 , chamando a atenção de seu missivista para a atuação bastante duvidosa de um dos principais colaboradores no empréstimo: José Pires de Carvalho e Albuquerque, Secretário de Estado e Governo do Brasil, que além de ser um dos principais credores da coroa portuguesa na Bahia, foi quem sugeriu ao governador o modo perspicaz para se descobrir os réus da referida revolta: a comparação das letras dos pasquins sediciosos com as letras de algumas petições arquivadas na Secretaria de Estado ${ }^{276}$.

Vilhena não comenta em suas cartas sobre o Secretário de Estado e Governo do Brasil, restringindo-se apenas às questões administrativas relativas ao órgão ${ }^{277}$. No entanto, seus comentários acerca de sua própria situação no interior da estrutura administrativa da capitania da Bahia nos sugerem algumas questões importantes. Em vários momentos de suas cartas, o cronista afirma que a relação dos professores régios com as autoridades locais estava longe de ser tranquila, pois várias representações chegavam a Lisboa denunciando os desmandos na Junta da Real Fazenda em relação ao atraso no pagamento dos professores régios.

Em uma das denúncias, que provavelmente Vilhena conhecia ou ajudou a fazer, a queixa recaia sobre o escrivão da Fazenda Francisco Gomes de Souza e sobre o tesoureiro dos ordenados Manoel José Villela de Carvalho ${ }^{278}$, suspeitos de fazerem mau uso da verba pública ${ }^{279}$. D. Fernando José de Portugal e Castro reagiu com extrema indignação, respondendo a d. Rodrigo de Sousa Coutinho que:

"a sobredita Reprezentação he inteiramente falta de verdade não só pelo que toca ao motivo do atrazamento dos pagamentos dos Professores, mas pelo que pertence ao Caracter do Contador Francisco Gomes de Souza que actualmente serve de Escrivão da Junta da Real Fazenda

\footnotetext{
${ }^{275}$ Luís dos Santos Vilhena, op.cit., p. 426. Grifo meu.

${ }^{276}$ Cf. ADCA, vol. 1, pp. 86-89 e 123-124.

${ }^{277}$ Luís dos Santos Vilhena, op.cit., p. 297 et seq.

${ }^{278}$ Chamo atenção para o fato de que Manoel Villela de Carvalho era um dos proprietários dos escravos entregues à justiça durante as investigações da Conjuração Baiana de 1798.

${ }^{279}$ BN, Fundo Marquês de Aguiar, doc. $n^{\circ} 140$.
} 


\section{desta Capitania e do Thesoureiro Manoel José Vilella de} Carvalho ..." $" 280$.

Após refutar a acusação contra os funcionários de sua administração, o governador da Bahia explicou a d. Rodrigo de Sousa Coutinho que o atraso no pagamento ocorria porque a despesa total dos ordenados dos professores régios, no final do século XVIII, era de 10 contos e quinhentos mil réis e a receita arrecadada para o Subsídio Literário girava em torno de oito contos de réis ${ }^{281}$. D. Fernando encerrou sua resposta, afirmando que Francisco Gomes de Souza era:

"hum Official muito honrado, inteligente, e que cumpre exactamente com as suas obrigaçoens, e summamente zeloso pelos interesses da Real Fazenda, circunstancias que nelle tenho reconhecido desde que governo esta Capitania sendo este conceito que delle formo, e todas as pessoas cordatas, $e$ desapaixonadas, que o conhecem, o que obrigou a Junta da Real Fazenda encarregar-lhe a inspeção da obra do Collegio dos extintos Jesuitas que hade servir de Hospital Militar e assim só posso atribuir a calumnia o que a seu respeito se refere no extracto, considerando o até monopolista com o Thesoureiro dos Ordenados Manoel Jozé Vilella de Carvalho,"282.

Apesar da defesa de d. Fernando José de Portugal e Castro, para Vilhena, a Junta da Real Fazenda - órgão responsável pelo recebimento da coleta do subsídio literário arrecadado pelas câmaras, para em seguida pagar todos os professores - padecia dos vícios decorrentes das ações de um seleto grupo da administração local que Vilhena denominou de corporação dos enteados, sem indicar evidentemente o nome dos funcionários $^{283}$. Muito provavelmente a ausência de nomes se deve ao fato de que naquele final de século, a partir de 1793, quando José Pires de Carvalho e Albuquerque era Deputado, a Junta da Real Fazenda ordenou que:

"nenhum Professor, ou Mestre recebesse quartel algum de seu ordenado sem apresentar uma atestação de algum dos membros da Junta, ou Magistrados, sendo da Cidade, ou do Corregedor, sendo da Comarca"284.

\footnotetext{
${ }^{280}$ Idem.

${ }^{281}$ Idem.

282 Ibidem

${ }^{283}$ Op. cit. pp. 282. Grifo meu.

${ }^{284}$ Idem, p. 277.
} 
Segundo Vilhena, essa ordem obrigou a que alguns professores régios morassem "debaixo dos telhados da mesma Junta", mendigando por suas atestações para que pudessem receber seus ordenados. Situação que dava "lugar a suspeita de que naquela corporação reina o pirronismo", pois alguns professores régios acabavam:

"pagando ao escrivão do Tesoureiro [da Junta da Real Fazenda] os recebimentos destas atestações, além de um tostão que já antes lhe pagavam pelo recibo que de cada um dos quartéis passa na folha respectiva, vindo desta forma a ficar sem validade a lei que determina, se não pague em casos tais nas casas da arrecadação da Real Fazenda"285.

O escrivão da Junta da Real Fazenda, como se viu, era Francisco Gomes de Sousa, que entrou no lugar de José Pires de Carvalho e Albuquerque, e o tesoureiro era Manoel José Vilella de Carvalho, ambos denunciados na representação sobre mau uso de verba pública. Como professor de língua grega e homem de letras, Vilhena elogiou a substituição ocorrida na Junta da Real Fazenda muito provavelmente porque sabia da relevância de José Pires de Carvalho e Albuquerque ao franquear ao governador os documentos arquivados na Secretaria de Estado e Governo do Brasil, "que dantes era um caos [...] como da Junta da Arrecadação da Real Fazenda” que, como se viu, ficava em uma das propriedades do Secretário de Estado ${ }^{286}$.

Seja como for, não era apenas a Junta da Real Fazenda que continha funcionários que praticavam abusos. Ao comentar sobre o Senado da Câmara, o professor de língua grega afirma que abusos ocorriam porque "em parte se deve a falta de governo econômico, e respeitos particulares que de muitos dos que anualmente entram naquela governança, interessados mais nos seus cômodos, de parentes, e amigos, do que zelosos do bem público"287. Após elucidar o modus operandi da corporação dos enteados, Vilhena critica a sobreposição de poderes que ocasionava desordens administrativas como, por exemplo, a interferência do Tribunal da Relação da Bahia e as portarias dos governadores em assuntos que eram da alçada do Senado da Câmara. Para o professor de língua grega quando os:

"Governadores interpõe a parte um agravo para a Relação, $e$ tem por certo o provimento com que já conta quando agrava; motivo porque vem a ficar sem validade as posturas, $e$ reiteradas Portarias o Senado, ou para melhor, o Presidente iludido, e os perversos com a mão alçada para descarregarem

\footnotetext{
285 Idem, p. 278.

${ }^{286}$ Ibidem, pp. 426.

${ }^{287}$ Ibidem, p. 78.
} 
quando este obsta as suas pretensões. Ora esta privação que o Senado sofre das suas jurisdições privativas, e deliberações no governo econômico, são muito dignas de reflexão"288.

Além dos funcionários da Junta da Real Fazenda e da sobreposição de poderes nas posturas do Senado da Câmara, Vilhena também sugere haver desordem e abuso de poder dos Comandantes das Ordenanças e dos corpos das tropas que, para ele, eram os responsáveis pela indigência a qual alguns professores estavam submetidos e a forma arbitrária com que os alunos eram recrutados para o serviço militar ${ }^{289}$. De acordo com as informações, os dois terços de ordenanças da Bahia, um do Norte, comandado por Cristóvão da Rocha Pita, e outro do Sul, comandado pelo Secretário de Estado José Pires de Carvalho e Albuquerque, cometiam tanto abuso e tanta desordem que, de um dia para o outro, ocorriam alterações consideráveis e "bem dignas de atenção".

Uma das razões é que antes da deflagração do levante projetado em 1798, o regimento pardo de Salvador foi passado pela primeira vez para um comandante branco, contrariando o conteúdo normativo desses regimentos, que até então impunham comandantes da mesma qualidade das tropas ${ }^{290}$. Chama a atenção, a esse respeito, a observação do cronista em relação ao Quarto Regimento Auxiliar da Artilharia:

“[...] bem certo é, que com esta qualidade de gente se não perde todo o cuidado que haja, mas não merece muita aprovação o tratamento que com aquele corpo se vê praticar o seu Comandante, que de Tenente que era em um dos Regimentos de Linha passou a Sargento-mor para comandar o dos Pardos, ficando tão pago de si com a sua não esperada fortuna, que segundo a fama divulga, parece ter transgredido os limites da equidade com todos os que têm praça no Regimento do seu comando [...]",291.

Por essa razão, Vilhena associa a queda e ausência de seus provimentos à substituição das patentes dos agregados que havia nos corpos de milícias, pois parte dos

\footnotetext{
${ }^{288}$ Ibidem, p. 79.

${ }^{289}$ Vilhena, op. cit. pp. 277-279.

290 Cf. A carta régia de 22 de março de 1766, durante o reinado de d. José I, dava bases para a reorganização das tropas de segunda e terceiras linhas, instituindo às milícias de cor de todas as honras, graças, franquezas, liberdades, privilégios e isenções que gozavam os capitães das tropas pagas, normalmente composta por brancos e portugueses. Kalina Vanderlei Paiva da Silva afirma que "na prática é difícil acreditar que os milicianos chegassem a ter realmente os mesmo privilégios e honras dos oficiais portugueses, mas com a institucionalização das milícias de cor, a Coroa cria a expectativa de posse dos ditos privilégios, além de permitir, involuntariamente, formas de ascensão para negros e pardos militares". Cf. Kalina Vanderlei Paiva da Silva. Nas solidões vastas e assustadoras: os pobres do açúcar e a conquista do sertão de Pernambuco nos séculos XVII e XVIII. Tese de Doutoramento, UFPE, Recife, 2003, p. 183. Ler, especialmente o item 2.2 Henriques e Pardos: as milícias de cor, pp. 157-185.

${ }^{291}$ Luís dos Santos Vilhena. Op. cit., p. 245, vol. 1.
} 
provimentos do subsídio literário foi usado para a despesa com fardas e patentes que, a seu ver, "para nada lhes ficavam servindo" ${ }^{292}$.Além disso, Vilhena mostrava-se profundamente contrariado com as atitudes de d. Fernando José de Portugal e Castro, que depois de derrogar algumas patentes, fez uma "numerosa promoção" nos três corpos da tropa de linha, de tal sorte que "por elas vieram alguns a fundar a sua fortuna sobre a infelicidade de outros ${ }^{, 293}$.

Ao denunciar os desmandos dos comandantes das tropas urbanas e a iniquidade do poder local, Vilhena alerta seu missivista, Filipono, para a exasperação dos ânimos dos milicianos, cuja matéria pedia uma reflexão mais detalhada, posto que as condenáveis atitudes pudessem gerar:

“[...] alguma consequência não esperada, logo que eles se consideram em sumo desprezo, por se lhes dar um comandante, que não seja da sua qualidade, e que este seja um sargento-mor, quando os Henriques, com quem eles não querem comparar-se, ficam com o seu Coronel preto" ${ }^{, 294}$.

Não à toa, na mesma carta, Vilhena comenta sobre algumas reformas ocorridas na Intendência da Marinha e Armazéns Reais e afirma sobre a Secretaria de Estado e Governo do Brasil que:

"houve em 1797 a alteração de se acrescentarem a meio dobro os ordenados aos oficiais dela, à imitação de alguns na Junta da Arrecadação da Real Fazenda, e isto por representações que a favor de todos fez o nosso Exmo. Governador atual [d. Fernando], e por este motivo já aqueles oficios, e outros mais carecem de novas avaliações... "295.

Vilhena refere-se com indignação ao aumento dos ordenados dos oficiais da Secretaria de Estado e da Intendência da Marinha quando os professores régios não recebiam seus ordenados com regularidade. Para ele, a situação era tal que, não raras vezes, os próprios membros da justiça denunciavam uns aos outros. É o caso, por exemplo, dos Livros-Mestres dos Regimentos, que Vilhena não via utilidade, pois “[...] a honra de servir nesse Reino [Portugal] a S. Majestade observei, que eram como sagrados os Livros-Mestres; aqui porém os vejo em extremo profanados "296. Não parece ser à toa que Vilhena elogia a atitude da administração metropolitana ao proibir, em 1799, que os Ministros do Conselho Ultramarino e todos os Ministros do Tribunal

\footnotetext{
${ }^{292}$ Cf. Luís dos Santos Vilhena, op.cit., p. 424.

293 Idem, p. 425.

${ }^{294}$ Idem.

${ }^{295}$ Vilhena, idem, p. 345.

${ }^{296}$ Vilhena, p. 247.
} 
da Relação da Bahia aceitassem presentes, por mais insignificantes que fossem da parte "dos governadores e das demais pessoais empregadas [no] Real serviço... [e] nesta real determinação estão incluídos os oficiais da Secretaria de Estado" ${ }^{\text {297. }}$.

Vilhena não avança na crítica conservadora que elabora sobre o modo de governar "a bem das circunstâncias" de d. Fernando José de Portugal e Castro nem sobre os vícios que padeciam os homens da corporação dos enteados, preferindo ironizar a brandura de ânimo e o caráter contemporizador do governador como causa para a desordem da administração local ${ }^{298}$, afirmando ao seu missivista que "o certo é que os homens bons vêm muitas vezes a parecer maus por julgarem os outros homens por si, no que se enganam de ordinário "299. Apesar da ausência de nomes dos membros da administração que cometiam abusos e desordens, seus cargos nos permite afirmar que para o professor régio de língua grega: José Pires de Carvalho e Albuquerque, Manoel José Vilella de Carvalho, Francisco Gomes de Souza e alguns desembargadores do Tribunal da Relação da Bahia ocupavam lugar de destaque na corporação dos enteados.

O fato é que a corporação dos enteados contava com mais membros da administração de d. Fernando José de Portugal e Castro, pois durante os anos de 17971798 várias denúncias, a maioria apócrifa ${ }^{300}$, chegaram ao Reino dando conta dos desmandos cometidos pelos funcionários da administração do governador d. Fernando José de Portugal e Castro. Nessas cartas, o que mais causava revolta aos denunciantes, para além da convulsão social da cidade frequentemente denunciada, era a "frouxidão" com a qual d. Fernando conduzia os interesses metropolitanos na Bahia e a sua "contemporização" em relação à "ausência de limpeza de mãos" de alguns dos funcionários da sua administração, especialmente os desembargadores do Tribunal da Relação da Bahia, constantemente denunciados.

\footnotetext{
297 Vilhena, idem, p. 362. Braz do Amaral indica nas anotações à obra de Vilhena que o documento original está no Arquivo Público da Bahia, no códice das Ordens Régias, 1799, livro 83, doc. n. 539.

${ }^{298}$ Idem, pp. 423-428.

${ }^{299}$ Ibidem.

300 Algumas denúncias eram reenviadas para que o denunciado tomasse ciência sem o nome do denunciante. É o caso, por exemplo, de uma extensa carta de D. Fernando José de Portugal e Castro a d. Rodrigo de Souza Coutinho na qual o governador respondeu às denúncias sobre o seu governo. Afirma o

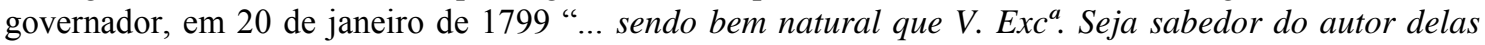
[denúncias], se é que não ocultaram os seus nomes, como às vezes o praticam como é de péssimas consequências, não só porque deste modo soltam a língua mais atrevida e sem rebuço, dando muitas vezes lugar à calúnia, mas também porque desta sorte fica impune a maledicência que devera ser castigada quando os fatos ou se não verificam, ou são concebidos em termos insolentes e insultantes...". Fernando José de Portugal e Castro para d. Rodrigo de Sousa Coutinho. Apud Braz do Amaral na obra de Luís dos Santos Vilhena. Notícias Soteropolitanas e Brasílicas. Salvador, Itapuã, 1969, vol. 2, p. 367.
} 
Na denúncia com conteúdo mais virulento, afirmava-se:

"A Vossa Magestade representão os Povos da Capitania da Bahia a ruina de que se vem oprimidos por falta de administração de justiça a qual se acha fraudada $e$ corrompida pelos Magistrados daquela Relação de que sem temor de Deos, e respeito as Leys de Vossa Magestade, se deixão prevaricar por donativos e dinheiros dos ricos habitantes daquella Cidade e seu termo, reinando dispotismos, violência e vil interesse daqueles Ministros em gravíssimos damnos aos pobres e miseráveis [...] $]^{, 301}$.

Em seguida, os denunciantes apresentam a S. M. "os horrorosos factos dos corrompidos Ministros", a começar pelo Chanceler da Relação da Bahia, Firmino de Magalhães Siqueira da Fonseca, que era acusado de sobrepor a liturgia de seu cargo ao do governador, de manter concubinato público com a viúva de Carlos Manoel Gago da Câmara e de receber "minos de Vitella, capados, galinhas e parella de cavalos de sege" do Juiz de Fora da Vila de Cachoeira, Joaquim de Amorim e Castro, para deixá-lo " $a$ salvo da continuada usurpação que pratica ao Povo daquella dita Villa", e receber a quantia de seis contos para proteger o Juiz de Fora "de hum negócio litigioso a requerimento de João Luiz Tavares contra hum advogado da mesma Villa". Além disso, e o mais grave, o Chanceler era acusado de negociar fazendas que vinham de Portugal em nome do seu criado, Alberto, que também recebia cargas grandes de contrabando de tabaco, açúcar e algodões ${ }^{302}$.

O desembargador Manuel de Magalhães Pinto e Avellar de Barbedo, também responsável por uma das devassas da Conjuração Baiana de 1798, foi acusado de ter obtido duzentos mil cruzados como Ouvidor do Ceará, de ser pouco tratável pelo seu gênio brusco e de não adiantar os processos da Vara do Crime, resultando em grande lotação no segredo da Relação ${ }^{303}$. Sobre o desembargador José Francisco de Oliveira, os denunciantes o acusaram de ter um péssimo caráter, de ser mentiroso e "embusteiro por hábito e profissão" e praticar toda a sorte de prevaricação com intenção de lucros, solicitados às partes envolvidas nos processos, especialmente os negociantes e senhores de engenho, para proferir sentença favorável a quem mais desse.

O desembargador Francisco Sabino Álvares da Costa Pinto, responsável por uma das devassas da Conjuração Baiana de 1798, foi acusado de prática de contrabando de fazendas que vinham de Portugal e de vender gado "por muito menos de que merecem,

\footnotetext{
${ }^{301} \mathrm{BN}$, Sessão de manuscritos, 01, 04, 009, doc. no 129.

${ }^{302}$ Idem.

${ }^{303}$ BN, Sessão de Manuscritos, doc: 01, 4, 009, nº 108.
} 
ficando ele Desembargador com huma grande parte da quantia". Além disso, Costa Pinto era acusado de valer-se da influência que seu pai tinha na corte para obter dinheiro das partes envolvidas em algum tipo de litígio ou intenção na capitania da Bahia:

"como fora o de seis mil cruzados com que se diz ter concorrido hum advogado mulato chamado João da Costa Carneiro para ser provido em Juiz de Crime da Bahia sem embargo de não ter lido na Mesa do Desembargo do Paço, 304 .

Além disso, José Francisco de Oliveira e Francisco Sabino Álvares da Costa Pinto eram considerados "odiosos" na capitania da Bahia por terem recusado a participar da comissão designada por d. Fernando José de Portugal e Castro, que iria investigar as denúncias de prática de contrabando do governador e do provedor das Ilhas de São Tomé e Príncipe ${ }^{305}$.

O fato é que as denúncias de abuso de poder, prevaricação e prática de contrabando dos desembargadores do Tribunal da Relação da Bahia, sobretudo os encarregados das devassas da Conjuração Baiana de 1798, eram constantes naquele final de século XVIII, de sorte que d. Rodrigo de Sousa Coutinho escreveu ao governador da capitania da Bahia:

"Vossa Senhoria pode muito bem suppor a impressão que tem feito no Real Ânimo humas acuzaçoens de tal natureza que se forem verdadeiras, como he bem de recear que o sejão em parte, são capazes de produzir os mais funestos effeitos" ${ }^{, 06}$.

D. Fernando José de Portugal e Castro mostrou-se indignado com a carta de d. Rodrigo de Sousa Coutinho. Em 20 de janeiro de 1799, escreveu uma extensa refutando cada denúncia que pesava sobre os desembargadores da Relação da Bahia, sobretudo do Chanceler da Relação, de Francisco Sabino Álvares da Costa Pinto, de Manuel de Magalhães Pinto e Avellar de Barbedo, do Juiz de Fora da Vila de Cachoeira, Joaquim de Amorim e Castro, e do escrivão do crime João Luís de Abreu. Para o governador da capitania da Bahia, a carta de d. Rodrigo de Sousa Coutinho acerca das denúncias contra os desembargadores significava:

"a primeira vez no espaço de onze anos que chega às minhas mãos representação remetida da Corte em que se pretenda diminuir aquêle conceito que mereço de S. Majestade e do

\footnotetext{
${ }^{304}$ Ibidem.

${ }^{305}$ A comissão das Ilhas de São Tomé e Príncipe, designada pelo governador da capitania da Bahia, será tratada adiante.

${ }^{306}$ BN, Sessão de Manuscritos, doc: 01, 4, 009, no. 119.
} 
público, tal é a desgraça até daqueles governadores que servem com toda honra e são prontos na execução das Reaes Ordens [...]. Sinto infinito que no tempo do meu governo chegassem a Real Presença queixas tão graves contra os desembargadores e não me consola encontrar nos livros desta Secretaria e nos da Relação vários documentos que bem comprovam que em diversas épocas os tem havido"307.

Para d. Fernando José de Portugal e Castro, a melhor maneira de se evitar as denúncias contra os desembargadores da Relação da Bahia que chegavam ao reino era "a escolha a mais escrupulosa sobre os ministros que forem nomeados para servirem na América", pois, caso contrário, "não pode a Justiça ser bem administrada, nem os governos viverem satisfeitos e sossegados". O governador da capitania da Bahia terminou sua resposta a d. Rodrigo, afirmando que "seria para mim da maior satisfação e sossego, obter outro qualquer emprego em que fosse meramente responsável pelas minhas ações e não pelas alheias" ${ }^{\prime 308}$.

Evidentemente que a coroa portuguesa não acatou a sugestão de d. Fernando José de Portugal e Castro em designá-lo para outro emprego em razão das denúncias de prevaricação dos desembargadores do Tribunal da Relação da Bahia, que não foram devassados nem punidos pelos crimes denunciados. Das várias razões que explicam a atitude da coroa portuguesa em não investigar de fato as denúncias, a mais óbvia é que não havia na colônia órgão superior ao Tribunal da Relação da Bahia e do Rio de Janeiro, cujos desembargadores eram os nobres da administração colonial, os mais respeitados e cheios de privilégios entre os funcionários régios ${ }^{309}$.

Stuart Schwarz demonstra que a coroa portuguesa via o Tribunal da Relação como o principal guardião de seus interesses em razão de ocupar posição central dentro de um sistema burocrático contraditório, com superposições jurisdicionais e com objetivos múltiplos. Justamente por isso, em casos de conflitos de jurisdição, conflitos entre os desembargadores ou denúncias de prevaricação, eventualmente tais situações eram remetidas ao Conselho Ultramarino para que a coroa desse seu parecer final. Situação que não ocorreu naquele final de século na Bahia, pois conforme a tese de Stuart Schwarz, as falhas dos magistrados eram compensadas pelas funções políticas

\footnotetext{
307 APUD, Braz do Amaral na obra de Luís dos Santos Vilhena. Notícias Soteropolitanas e Brasílicas. Salvador, Itapuã, 1969, vol. 2, p. 371.

308 Idem, pp. 371-372.

${ }^{309}$ Cf. Stuart B. Schwarz. Burocracia e sociedade no Brasil Colonial, op.cit. p. 287-295.
} 
que eles acabavam desempenhando ${ }^{310}$. Como de fato ocorreu com os magistrados que conduziram as investigações da Conjuração Baiana de 1798.

Justamente porque a coroa portuguesa e o governador da capitania da Bahia nada faziam em relação à desordem administrativa e às denúncias encaminhadas ao reino, outros contemporâneos descreveram aquela situação. Segundo o relato do Conde de Murça, d. Miguel Antônio de Mello ${ }^{311}$, a situação não estava nada boa na capitania da Bahia "por ser tão viciosa a nossa Legislação ou para melhor dizer a practica do Foro”. A viciosa prática do foro, segundo o Conde de Murça, decorria das características pessoais de d. Fernando José de Portugal e Castro:

"hum bom servidor, isento, afável para com grandes $e$ pequenos, mui pronto em ouvir e despachar o que ante a elle requerem; mais piedoso que justiceiro, o que talvez o tenha feito qualificar de frouxo, dado a ousadia com que alguns de seus súditos menor bem não lhe obedeção"312.

D. Miguel chamava a atenção de d. Rodrigo de Sousa Coutinho para a atitude de d. Fernando José de Portugal e Castro no episódio deflagrado em 1796, nas ilhas de São Tomé e Príncipe, denunciando o envolvimento na prática de contrabando de escravos e tecidos do governador das ilhas, João Rosendo Tavares Leote, e do ouvidor Antônio Pereira Bastos Luna Varella Barca, irmão de Joaquim Pereira Bastos, proprietário de um dos escravos entregues à justiça por ocasião das investigações da Conjuração Baiana de $1798^{313}$.

Como as ilhas de São Tomé e Príncipe eram da jurisdição da Bahia desde 1753, quando deixou ter o sistema donatorial e voltou para os domínios da Coroa Portuguesa junto com as Ilhas de Fernando Pó e Ano Bom, que foram entregues à Espanha por ocasião do Tratado do Pardo, assinado em 1778 -, cabia ao governador da Bahia a nomeação e a garantia de posse do governador e do ouvidor das Ilhas, com a anuência de S. A. R, bem como cabia à Mesa de Inspeção da Bahia o regulamento do comércio da África ${ }^{314}$.

\footnotetext{
${ }^{310}$ Idem.

${ }^{311} \mathrm{BN}$, Divisão de Manuscritos, I-31, 21, 023, docs. 1 e 2.

${ }^{312} \mathrm{BN}$, sessão de manuscritos, I-31, 21, 023, doc. 1 .

${ }^{313}$ AHU_ACL_CU_005, Cx. 215, doc. 15108. "Consulta do Conselho ao Príncipe Regente referente às devassas procedidas nas ilhas de São Tomé e Príncipe e sobre a Representação de João Rosendo Tavares Leote, que foi governador das ditas ilhas e faleceu na Bahia. Lisboa, 28 de setembro de 1798".

${ }^{314} \mathrm{Cf}$. Carlos Filomeno Azevedo Agostinho das Neves. S. Tomé e Príncipe na $2^{a}$ metade do século XVIII. Lisboa: CHAM, 1988.
} 
Próximas à Costa Africana, as ilhas de S. Tomé e Príncipe foram importantes centros de concentração e reexportação de escravos para o Brasil, especialmente para a Bahia. As ilhas foram portos de guarida aos navios portugueses e de fiscalização das cargas dos navios da Bahia que, por Ordem do Real Erário de 18 de outubro de 1773, eram obrigados a escalarem nas ilhas, tanto na ida como na volta. Na ida, a escala ocorria para se verificar a quantidade de tabaco que transportavam e se os navios levavam ouro em contrabando; na volta, para se verificar o número de escravos, cobrar os meios direitos por esse comércio e evitar o contrabando de tecidos ${ }^{315}$. No entanto, não eram apenas os navios portugueses que frequentavam os portos das ilhas, pois de acordo com as cartas marítimas do final do século XVIII, os navios ingleses paravam no porto de S. Tomé porque ali tomavam mais facilmente a volta para o oeste, e os franceses porque no porto do Príncipe abasteciam os seus navios ${ }^{316}$.

Como o sistema econômico de São Tomé e Príncipe era totalmente dependente do tráfico de escravos de Portugal e de outras nações, qualquer flutuação no tráfico da Costa da Mina repercutia imediatamente nas finanças das ilhas. No final do século XVIII, não foram poucas as reclamações das autoridades das ilhas sobre a falta de navios da Bahia, muito provavelmente em razão de terem de submeter suas cargas à fiscalização e realizarem o pagamento da metade dos direitos dos escravos, que no final das contas era o que equilibrava as finanças das ilhas.

Por volta de 1787, quando Antônio Pereira Bastos já era ouvidor-geral e João Rosendo Tavares Leote era o governador das ilhas, as taxas e os emolumentos cobrados atingiram níveis altíssimos, tornando as escalas bastante dispendiosas. Os navios portugueses pagavam 60:600 réis e os estrangeiros 48:800 réis. Além disso, pagavam ao provedor da fazenda 6:400 réis, a mesma quantia ao feitor, 1:600 réis a cada escrivão da alfândega, 800 réis ao meirinho, sem que para isso houvesse qualquer determinação régia a respeito ${ }^{317}$. Para evitar o desvio de rota e garantir que os navios da Bahia fizessem escalas nos portos das ilhas, a Coroa instituiu a condenação dos mestres e proprietários das embarcações com o pagamento do dobro dos direitos pelo comércio de escravos aos que não escalassem naqueles portos, gerando protestos e reações de toda a sorte na Bahia.

\footnotetext{
${ }^{315}$ Idem, pp. 202-205.

${ }^{316}$ APEB, Colonial, Correspondência recebida pelo Governo da Bahia pelos Governos Estrangeiros (1786-1799), Maço 197, Cx. 76, doc. 01.

${ }^{317}$ AHU_CU_CA_Cx. 105, doc. 20589.
} 
Para os membros da Mesa da Inspeção da Bahia, a severidade do procedimento régio retardaria o progresso do tráfico de escravo, causando imenso prejuízo à lavoura e ao comércio da Capitania, já bastante prejudicados pela "infestação dos inimigos na Costa da Mina e mares adjacentes", tornando-se prudente que os mestres das embarcações evitassem o encontro com os inimigos, desviando-se com mudança de rota dos lugares "notoriamente infestados de Corso" 318 . Depois de enumerar uma série de embarcações que, ao escalarem nas ilhas de S. Tomé e Príncipe, perderam seus escravos por fuga, por morte pelas emanações pestilentas em razão do clima, ou, ainda, pela ação dos corsários franceses, os membros da Mesa da Inspeção da Bahia, entre eles José da Silva Lisboa, argumentaram que:

"algum detrimento destas Ilhas, por falta das arribadas das Embarcações de resgate, parece não poder entrar em consideração à vista dos interesses incomparavelmente superiores q'se deixão indicados, sendo mais opportuno ser da Bahia para alli remettido o dinheiro dos Direitos dos Escravos destinados originariamente para subsistência das mesmas Ilhas, q'pela sua posição e qualidade não podem reclamar da Real Grandeza hú gênero de protecção q'trazia a perda de muitas vidas, maiores riscos ao Comércio de África e incalculável diminuição dos produtos da Lavoura deste Paiz ${ }^{, 319}$.

Por se tratar de um importante entreposto comercial da Coroa Portuguesa no tráfico da Costa da Mina, a disputa entre a Inglaterra e a França intensificou-se nas ilhas de São Tomé e Príncipe no final do século XVIII. Em 1783, por exemplo, os ingleses atacaram navios franceses no porto do Príncipe, pertencentes à Companhia Francesa de Comércio de Bordeaux - criada em 1790, com sede na ilha do Príncipe -, e colocaram-se à disposição das autoridades locais para proteger todos os navios portugueses na região.

O interesse dos ingleses no comércio de escravos e tecidos na região era tanto que no mesmo ano uma fragata da marinha inglesa atacou a cidade de Santo Antônio para coibir as autoridades locais que insistiam em manter relações pouco ortodoxas com os comerciantes franceses. Dois anos depois, uma poderosa esquadra francesa efetuou violentos ataques contra os portugueses e ingleses na Costa da Mina, preservando, contudo, São Tomé e Príncipe, porque, segundo governador João Rosendo Tavares Leote, era bom o estado da tropa permanente ${ }^{320}$.

\footnotetext{
${ }^{318}$ Idem.

${ }^{319}$ Ibidem.

${ }^{320}$ Neves, op.cit., p. 110.
} 
As razões pelas quais os franceses preservaram as ilhas de São Tomé e Príncipe não estão relacionadas às condições da tropa, que àquela altura encontrava-se em estado deplorável, com falta de farinha e armamentos, em razão do desequilíbrio financeiro ocasionado pela sensível diminuição de navios da Bahia que deveriam fazer escalas nos portos das ilhas. Os franceses preservaram São Tomé e Príncipe porque, de acordo com a denúncia do então Capitão-mor das Ilhas, João Baptista da Silva, tanto o governador como o ouvidor mantinham relações de sociedade no contrabando de tecidos e tabaco com os comerciantes da Companhia de Bordeaux ${ }^{321}$.

Não que as autoridades portuguesas desconhecessem a atuação dos comerciantes franceses nas ilhas, muito pelo contrário, pois a companhia de comércio francesa fora fundada com o consentimento das autoridades régias. O que irritou profundamente d. Rodrigo de Sousa Coutinho foi a denúncia de que o governador, o ouvidor e o mais rico morador da ilha do Príncipe negociavam com os comerciantes franceses suas idas à Costa da África para carregarem seus navios de escravos e ouro, sem que na volta essas embarcações escalassem nas ilhas, aumentando significativamente o prejuízo da Real Fazenda $^{322}$.

Não à toa, em carta régia de 19 de novembro de 1796, d. Rodrigo de Sousa Coutinho ordenava que d. Fernando José de Portugal e Castro designasse com a maior urgência um desembargador daquela Relação para, chegando a São Tomé, suspendesse o governador e o ouvidor, os remetesse sob prisão de volta para a Bahia, e, em seguida, procedesse a uma rigorosa devassa ${ }^{323}$. Muito embora o caso exigisse a maior urgência, foi somente pelas Portarias de 22 e 23 de março do ano seguinte, 1797, que d. Fernando José de Portugal e Castro ordenou que os desembargadores José Francisco de Oliveira e Francisco Sabino Álvares da Costa Pinto partissem para a missão em São Tomé e Príncipe $^{324}$. Se o governador demorou quase quatro meses para a escolha dos desembargadores para a missão de São Tomé e Príncipe, rendendo-lhe, inclusive, uma repreenda de d. Rodrigo pelo o que a demora causara ao Real ânimo, cumpre destacar a rapidez do desenrolar dos acontecimentos.

O desembargador Francisco Sabino Álvares da Costa Pinto escreveu uma carta no mesmo dia de sua designação, em 23 de março de 1797, para que o Secretário de Estado, José Pires de Carvalho e Albuquerque, apresentasse ao governador sua escusa

\footnotetext{
${ }^{321}$ BN, Sessão de Manuscritos, Obras Raras, C-837, 2.

${ }^{322}$ AHU, São Tomé, Caixa 24, doc. 9.

${ }^{323}$ AHU_ACL_CU_005, Cx. 215, doc. 16630.

${ }^{324}$ AHU_ACL_CU_005, Cx. 215, docs. 17235-17236.
} 
da comissão de serviço para São Tomé, alegando motivos pessoais ${ }^{325}$. O governador não deixou por menos e no mesmo dia 23 de março de 1797, baixou outra Portaria na qual obrigou o desembargador Costa Pinto a cumprir as ordens que recebera, pois caso contrário o suspenderia das suas atribuições ${ }^{326}$. No dia seguinte, o desembargador Costa Pinto escreveu uma nova carta a José Pires de Carvalho e Albuquerque, pedindo para que o Secretário de Estado insistisse com o governador na sua recusa em executar as ordens que recebera e protestou contra a ameaça de suspensão contra ele e o desembargador José Francisco de Oliveira - que àquela altura também havia recusado a participar da missão -, sob a alegação de ser a atitude do governador uma enorme arbitrariedade.

A contenda se arrastou por mais dois dias, e tudo leva a crer que o Secretário de Estado José Pires de Carvalho e Albuquerque tenha convencido o governador sobre a relevância dos motivos pessoais alegados pelos desembargadores. Primeiro porque o desembargador Costa Pinto solicitou, em ofício de 12 de setembro de 1796, o serviço no cargo de Intendente da Marinha e Arsenal da Bahia, muito provavelmente em função da Portaria do Secretário de Estado da Marinha e Ultramar, Luís Pinto de Sousa ao Conde de Resende, solicitando que José Pires de Carvalho e Albuquerque fornecesse esclarecimentos sobre o livre embarque de cargas pertencentes ao desembargador Costa Pinto para as ilhas de São Tomé e Príncipe ${ }^{327}$.

Depois, a documentação sugere que d. Fernando José de Portugal e Castro não quis se indispor com o desembargador José Francisco de Oliveira que, no ano anterior, escreveu uma Representação a d. Rodrigo de Sousa Coutinho, queixando-se de ter sido preterido na nomeação para o lugar de Ouvidor Geral do Crime, que a seu ver:

"he e foi sempre da escolha, do arbítrio e da regalia do Governador fazer estas nomeações, sem que haja regimento, provisão ou qualquer outra ordem regia que estabeleça o contrário ou prescreva a forma e methodo de semelhantes provimentos ${ }^{, 328}$.

Ocorre que José Francisco de Oliveira foi preterido no cargo de Ouvidor Geral do Crime pelo Desembargador Manoel Magalhães Pinto e Avellar de Barbedo,

\footnotetext{
${ }^{325}$ AHU_ACL_CU_005, Cx. 215, doc. 17237.

${ }^{326}$ AHU_ACL_CU_005, Cx. 215, doc. 17238.

${ }^{327}$ AHU_ACL_CU_005, Cx. 202, doc. 14582, AHU_ALC_CU_005, Cx. 199, doc. 14394, respectivamente.

${ }^{328}$ AHU_ACL_CU_005, Cx. 215, doc. 21022.
} 
responsável por uma das devassas da Conjuração Baiana de $1798^{329}$. Em carta à Rainha, datada de 17 de novembro de 1795, na qual solicitou a serventia nas Ouvidorias do Crime ou do Civil da Bahia, o próprio Avellar de Barbedo confirmou que "costumão os Governadores provê-los [os cargos] quase sempre nas vias de sua predileção" ${ }^{\text {„30 }}$. Seja como for, em ofício de 26 de março de 1797, d. Fernando comunicou aos desembargadores que só não os suspenderam do exercício de suas funções, como de resto mereceria tamanho ato de desobediência em consideração ao transtorno que causaria suas faltas na Relação da Bahia ${ }^{331}$.

Assim, a contenda em relação à nomeação dos desembargadores para a missão de São Tomé e Príncipe foi resolvida definitivamente no dia 27 de março do mesmo ano, quando d. Fernando nomeou o desembargador José Joaquim Borges da Silva ${ }^{332}$, descrito na denúncia contra os desembargadores do Tribunal da Relação da Bahia como um ministro de "péssimo carácter, mentiroso e embusteiro por hábito e profissão; a afirmar-se constantemente ser disposto a toda a sorte de prevaricação com intenção de lucros $^{333}$. Não obstante as qualificações, ou justamente por elas, no dia 12 de abril de 1798, d. Fernando José de Portugal e Castro informou a d. Rodrigo de Sousa Coutinho que escreveu a S. M. solicitando a mercê de um lugar na Relação do Porto para o desembargador José Joaquim Borges da Silva ${ }^{334}$.

Em que pese alguns importantes trabalhos considerarem o Tribunal da Relação do Porto como o topo da carreira de um magistrado ${ }^{335}$, naqueles anos finais do século XVIII, ficar próximo “ao bafo do Rei” era um verdadeiro castigo, especialmente para os desembargadores denunciados por prática de contrabando. Como foi o caso do ex-

\footnotetext{
${ }^{329}$ Cf. "Devassa a que procedeo o Desembargador Ouvidor Geral, com vezes de Corregedor do crime da Coroa, o Doutor Manoel Magalhães Pinto e Avellar de Barbedo, na conformidade da Portaria do Ilmo. Exmo. Governador e Capitão General desta Capitania, sobre a factura, e publicação de vários papéis sediciozos, e revolucionários, que aparecerão nesta cidade do dia doze de Agosto de 1799”. In: ADCA. Salvador: Arquivo Público do Estado da Bahia, 1998, pp. 31-32. Chamamos a atenção para o fato de que o ano da publicação dos pasquins sediciosos é 1798 e não 1799 como é citado na documentação da devassa.

330 AHU_ACL_CU_005, Cx. 199, doc. 14409.

${ }^{331}$ AHU ACL CU 005, Cx. 215, docs. 17243-17244.

${ }^{332}$ AHU_ACL_CU_005, Cx. 215, doc. 17234. Chamamos atenção para o fato de que no Livro de Registro de Provisões e Alvarás Régios, em Ofício de 25 de março de 1797, d. Fernando José de Portugal e Castro afirma "por ser necessário nomear Escrivão para a diligência das Ilhas de S. Tomé e Príncipe de que se acha por mim [designado] encarrego o Desembargador desta Relação José Joaquim Borges da Silva, em cumprimento da Carta Régia de 19 de novembro do anno passado [1796], nomeio para Escrivão della João Luís de Abreo".Cf. BN, Divisão de Manuscritos, 5,12,15 - pp. 151, 151v.

${ }^{333}$ BN, Sessão de Manuscritos, Livro de Registro das Provisões Régias: 01, 4, 009, doc. n $^{\circ} .108$.

${ }^{334}$ APEB, Fundo Governo Geral/Governo da Capitania, Registro de Correspondência expedida para o Rei (1797-1799), Maço 138, folhas $100 \mathrm{v}, 101,101 \mathrm{v}$.

${ }^{335}$ Ler a esse respeito: Stuart Schwartz. Burocracia e Sociedade no Brasil Colonial: a suprema corte da Bahia e seus juízes, 1609-1751. São Paulo: Perspectiva, 1979.
} 
ouvidor das Ilhas de São Tomé e Príncipe, Antônio Pereira Bastos Luna Varella Barca que, depois de condenado, sentenciado e preso, foi nomeado desembargador da Relação do Porto e, no ano seguinte, aparece solicitando licença régia em 19 de novembro de 1799, para voltar à Bahia em razão de uma moléstia que, no final das contas, foi diagnosticada falsa ${ }^{336}$.

O fato é que o procedimento do governador em relação à desobediência dos desembargadores do Tribunal da Relação da Bahia despertou um profundo mal-estar desse lado do Atlântico. Várias representações foram enviadas ao reino, denunciando os abusos de poder e prática de contrabando na administração de d. Fernando José de Portugal e Castro ${ }^{337}$. Para o Conde de Murça, se o procedimento de d. Fernando José de Portugal e Castro não foi louvado por Sua Majestade, deveria ao menos servir como lição para o futuro, pois:

\begin{abstract}
"todas as vezes que qualquer pessoa escusar sem razoens solidas, provadas, as portarias do Real serviço, [...] enervada ficará para sempre a authoridade do Governador; visto que só o temos de prompta correção e castigo [não] poderá cohibir principalmente os Magistrados dos excessos que cometem pela quase certeza em que vivem de que o Governador não pode contra elles proceder, nem privá-los da authoridade e jurisdição que lhes foi confiada",338.
\end{abstract}

Além disso, corroboraram para os relatos dos contemporâneos sobre as desordens na capitania da Bahia outras duas Representações, de 17 de setembro de 1796, nas quais os moradores da Vila de Cachoeira queixavam-se a d. Rodrigo de Sousa Coutinho das violências praticadas pelo Juiz de Fora, Joaquim de Amorim e Castro, em razão da construção de um engenho às margens do Rio Ipitanga, dificultando o acesso à água dos moradores. D. Rodrigo mais uma vez mandou que d. Fernando averiguasse as denúncias por meio de uma devassa. Para a tarefa, o governador designou o desembargador Ouvidor Geral do Crime, Manuel de Magalhães Avellar de Barbedo, que imediatamente se dirigiu à Vila de Cachoeira ${ }^{339}$.

Em poucos dias, Avellar de Barbedo concluiu que o engenho que motivou as denúncias não era de propriedade de Joaquim de Amorim e Castro, mas de sua irmã, e como as queixas não continham assinaturas, de tudo não passava de intriga e emulação

\footnotetext{
${ }^{336}$ AHU-ACL-CU_005, Cx. 215, doc. 15132.

${ }^{337}$ BN, Divisão de Manuscritos, 01,4,009, Livro de Registro e Provisões Reais, doc. 129.

${ }^{338}$ BN, Divisão de Manuscritos, I-31-21,023: Informaçam da Bahia de Todos os Santos.

${ }^{339}$ BN, Divisão de Manuscritos, 5, 2, 17, Livro de Registro e Provisões Reais, doc. 146.
} 
contra o Juiz de Fora, que "por ser natural da mesma Villa, e como nella excercita emprego público, não he de admirar que a seo respeito se tenhão fundamentado e suscitado intrigas e inimizades" ${ }^{340}$. D. Fernando encaminhou a conclusão de Avellar de Barbedo a d. Rodrigo, acrescentando a recomendação de que S. M. considerasse a possibilidade de transferir Amorim e Castro para outra função com todos os provimentos e honrarias a que o juiz tinha direito, o que de fato ocorreu quando Joaquim de Amorim e Castro foi nomeado desembargador do Tribunal da Relação do Rio de Janeiro em $1800^{341}$.

Não parece ser à toa que o autor anônimo de outra Representação enviada a d. Rodrigo de Sousa Coutinho, em meados de 1798, afirmou que:

"estas desordens principalmente provem da criminosa e mal entendida prudência do Governador que não querendo segundo diz intrometer-se na jurisdição de cada hum procedimento [...] sendo-lhe muito bem constante a infinita desordem dos Magistrados, não tem dado a V. M. conta dos maos procedimentos [por ter] elle Governador huma quase indefinida privança e amizade ao ex-Ouvidor do Crime [desembargador Avellar de Barbedo] de sorte que hoje se acha [o Ministro] muito rico e Senhor de Engenho onde habita"342.

Cumpre destacar que na Representação enviada a d. Rodrigo de Sousa Coutinho, datada de 28 de setembro de 1798, após descrever os arbítrios do Chanceler da Relação da Bahia e a quase ausência do Governador nas missas que abriam os trabalhos da Relação, o autor anônimo que denunciou as prevaricações de cada um dos desembargadores afirmou sobre os que recusaram a participar da missão de São Tomé e Príncipe:

"he este Ministro [José Francisco de Oliveira] de hum péssimo caracter, mentiroso e embusteiro por hábito e profissão a afirmar-se constantemente ser disposto a toda sorte de prevaricação com intervenção de lucros, os quais solicita por estipulação das próprias partes [...] procura com todo o cuidado tratar com amizade com tudo que diz respeito ao comércio e senhores de engenhos pelos obséquios lucrativos que deles espera $[\ldots]^{, 343}$.

\footnotetext{
${ }^{340}$ Idem.

${ }^{341}$ Cf. Arno Wehling \& Maria José Wehling. Direito e Justiça no Brasil colonial: o Tribunal da Relação do Rio de Janeiro, 1751-1808. Rio de Janeiro: Renovar, 2004.

${ }^{342}$ Idem.

${ }^{343}$ BN, Sessão de Manuscritos, Provisões Régias, 01, 4, 009, nº 108.
} 
Para o denunciante, o desembargador Costa Pinto era conhecido na capitania da Bahia por ter um:

"gênio insultante e aspero para as partes que não são seus escolhidos [e] pelo motivo de haver escusado sem causa da comissão de São Thomé, se fizera igualmente odioso nesta Capitania principalmente pelo modo com que se recusara a hum semelhante serviço, [...] e instando-lhe o Governador que visto não querer aceitar a Comissão, o havia fazer embarcar para ella forçosamente, respondeo que em taes circunstanceas no caso de lá chegar, não dava cumprimento as diligências ${ }^{, 344}$.

Depois de sugerir que o Governador da Bahia não tinha o menor controle sobre as prevaricações dos desembargadores do Tribunal da Relação da Bahia, o autor anônimo da denúncia sugeriu que d. Fernando José de Portugal e Castro também fazia vistas grossas ao seu principal colaborador na condução da administração local: o Secretário de Estado e Governo do Brasil, José Pires de Carvalho e Albuquerque. As ações do Secretário de Estado e Governo do Brasil desagradavam muito d. Rodrigo de Sousa Coutinho e algumas pessoas importantes da Bahia, pois em Lisboa foram várias as denúncias que acusavam o Secretário de Estado de enriquecimento ilícito, de contrabando de tabaco, de disputa pela herança do principal morgado da Bahia, o da Casa da Torre dos Garcia D’Ávila, e principalmente de atuação duvidosa à frente da Real Fazenda.

As tensões ocorridas na capitania da Bahia na última década do século XVIII e as atitudes de d. Fernando José de Portugal e Castro e da coroa portuguesa demonstraram um esforço político da administração régia em tirar proveito da proeminência econômica desse grupo de notáveis, a corporação dos enteados, comandados pelo Secretário de Estado e Governo do Brasil, José Pires de Carvalho e Albuquerque. Paradigmática nesse sentido é outra contenda ocorrida no final do século XVIII, dessa feita envolvendo as ações creditícias das Clarissas de Véu Preto do Convento da Santa Clara do Desterro.

É assente entre a historiografia da economia colonial que para a análise da condução de um engenho de açúcar é preciso considerar as várias formas de obtenção de crédito em razão da escassez do "dinheiro de contado" circulante e do risco do

\footnotetext{
${ }^{344}$ Idem.
} 
negócio do açúcar ${ }^{345}$. A escassez de moeda circulante era um problema que afetava a economia do Império Português como um todo, mas para a economia açucareira no Brasil, em especial na Bahia, esse processo fez com que o crédito, mais que o dinheiro, tornasse um bem definidor da riqueza e da acumulação colonial $^{346}$.

De acordo com Rae Flory, desde o início os senhores de engenho dependeram do crédito para iniciar as operações, pagar as despesas e custear a expansão de suas atividades. Para o período de 1680-1715, a autora analisou trezentos contratos de empréstimos, dos quais os senhores de engenho e lavradores de cana constituíram $41 \%$ dos tomadores e receberam $52 \%$ do crédito concedido. Embora as fontes de crédito na Bahia fossem difusas, no período analisado por Flory os empréstimos concedidos pelas instituições emprestadoras representavam $45 \%$ do volume total, sendo a Santa Casa de Misericórdia responsável por cerca de $60 \%$ e o Convento de Santa Clara do Desterro respondia por $17,5 \%$ do total de empréstimos, configurando-se como a segunda maior instituição de crédito do período entre os conventos e irmandades ${ }^{347}$.

O dinheiro obtido pela Misericórdia vinha de doações testamentárias e doações em vida. $\mathrm{O}$ montante adquirido era repassado a terceiros na forma de empréstimos a juros, que variaram de 5\% a 6,25\% ao ano. Os mutuários favorecidos pela Misericórdia eram aqueles que de alguma maneira tinham ligação estreita com a instituição, como os confrades e membros do conselho diretivo, cujo status e condição social eram atributos fundamentais para se conseguir vantagens na obtenção de empréstimo: quantia alta, juros inferiores ao da praça e prazos maiores para a quitação da dívida ${ }^{348}$.

O Convento de Santa Clara do Desterro, por sua vez, acumulava capital cobrando dotes no momento da inserção de uma noviça e por meio de legado. Tais quantias depois eram redirecionadas ao mercado na forma de crédito. Tal como a

${ }^{345}$ Cf. Bert J Barickmam, op.cit.; Caio Prado Júnior. Formação do Brasil Contemporâneo. $20^{\mathrm{a}}$ e. São Paulo: Ed. Brasiliense, 1987; Charles R Boxer. O Império Marítimo Português 1415-1825. Tradução de Inês Silva Duarte. Lisboa, Ed. 70,1993; Fernando A Novais. Portugal e Brasil na Crise do Antigo Sistema Colonial (1777-1808). São Paulo: Ed. Hucitec, 1995; Maria José Rapassi Mascarenhas. Fortunas coloniais: elite e riqueza em Salvador 1760 - 1808. Tese de Doutorado, DH/FFLCH/USP, 1999; Stuart B Schwartz; op.cit; Vera Lúcia Amaral Ferlini, op.cit.

346 Antônio Carlos Jucá de Sampaio. Crédito e Circulação Monetária na Colônia: o caso Fluminense, 1650-1750. V Congresso Brasileiro de História Econômica, Caxambu: ABPHE, 2003; A.J.R RusselWood. Fidalgos e filantropos: a Santa Casa da Misericórdia da Bahia, 1550-1755. Brasília: UnB, 1981; Claudinei Magno Magre Mendes. Crédito e Usura na época Colonial: Autores Coloniais e Historiografia. Mirandum 18, Universidade do Porto, 2007, pp. 31-48; Maria Bárbara Levy. História Financeira do Brasil Colonial. Rio de janeiro: IBMEC, 1979; Maria José Rapassi Mascarenhas, op.cit.; ${ }^{347}$ Rae J. Dell Flory. Bahia society in the mid. Colonial period: the sugar planters, tobacco growers, merchants, and the Recôncavo, 1680-1725. Tese PhD, University of Texas at Austin, mimeo. p. 70-71.

${ }^{348}$ Cf. A.J.R Russel-Wood. Fidalgos e filantropos: a Santa Casa da Misericórdia da Bahia, 1550-1755. Brasília: UnB, 1981. 
Misericórdia, o Desterro concedia créditos a mutuários escolhidos, com juros inferiores aos cobrados na praça. Mesmo com todas as facilidades, não foram poucas vezes em que tanto a Misericórdia quanto o Desterro tiveram dificuldades para receber o que havia sido emprestado ou mesmo os juros cobrados sobre a quantia. Por diversas vezes essas instituições tiveram que entrar na justiça para reaver o valor emprestado, resultando, em muitos casos, na perda do valor disponibilizado a crédito ${ }^{349}$.

Segundo Russell-Wodd, isso ocorria porque as regras sobre as garantias dos empréstimos não eram seguidas e, para a historiografia do tema, essa situação foi um dos motivos da queda brusca do peso das fontes institucionais de crédito realizadas a partir da década de 1760, sobretudo da Misericórdia, como demonstra o quadro abaixo:

Soma total dos empréstimos efetuados pela Santa Casa de Misericórdia de Salvador por década, 1751-1800.

\begin{tabular}{|c|c|}
\hline Década & Montante \\
\hline $1751-60$ & $56: 927 \$ 872$ \\
\hline $1761-70$ & $15: 878 \$ 928$ \\
\hline $1771-80$ & $10: 690 \$ 488$ \\
\hline $1781-90$ & $5: 530 \$ 000$ \\
\hline $1791-00$ & $1: 000 \$ 600$ \\
\hline
\end{tabular}

Fonte: APEB, Judiciário, livros de notas do $1^{\circ}$. e $2^{\circ}$. Ofícios de Salvador (livros 90 a 139).

No mesmo período, no entanto, cumpre destacar que a segunda maior instituição emprestadora entre os conventos e irmandades, o Convento de Santa Clara do Desterro, duplicou o montante de suas operações creditícias: durante o período de 1720-1760, a instituição foi responsável por 23,23\% dos empréstimos concedidos principalmente aos senhores de engenho. Durante o período de 1770-1810, esse percentual atingiu 47,75\%.

\footnotetext{
${ }^{349}$ Cf. Anna Amélia Vieira Nascimento. Patriarcado e religião: as enclausuradas clarissas do Convento do Desterro da Bahia, 1677-1890. Salvador: Conselho de Cultura, 1994, passim.
} 


\section{Percentuais de concessão de empréstimos pelo Desterro, na segunda metade do século XVIII.}

\begin{tabular}{|c|c|}
\hline Década & Montante em \% \\
\hline $1760-70$ & 6,45 \\
\hline $1770-80$ & 15,49 \\
\hline $1780-90$ & 11,62 \\
\hline $1790-00$ & 7,74 \\
\hline $1800-10$ & 12,90 \\
\hline $1810-20$ & 1,93 \\
\hline
\end{tabular}

Fonte: APEB, Livros de Notas dos Tabeliães 4-138; APUD, NASCIMENTO, p. 332.

Muito embora a perda de proeminência dessas instituições nas operações de crédito ao longo da segunda metade do século XVIII tenha ocorrido pela falta de quitação das dívidas, pelo fortalecimento do Juizado dos Órfãos como importante instituição emprestadora de crédito e pelo crescente fortalecimento de vários setores da sociedade soteropolitana da época nas operações de crédito, especialmente os negociantes, o que explicaria o Convento de Santa Clara do Desterro ter duplicado o montante destinado a crédito na mesma conjuntura? Para além de um maior controle metropolitano sobre as ações creditícias da Misericórdia no último quartel do século XVIII e a tentativa de criação de uma caixa de crédito na Bahia, a hipótese a esse respeito sugere a importância das ações de algumas abadessas clarissas do véu preto do Convento de Santa Clara do Desterro em acordo com alguns parentes, homens da administração local.

De acordo com Ana Amélia Vieira do Nascimento, as religiosas do véu preto ingressavam no Desterro de maneira majestosa, até mesmo pomposa, pois a condição social de seus pais concentrava-se no mais alto nível de riqueza ${ }^{350}$. Segundo Susan Soeiro, ao pleitear uma vaga, o pai da futura religiosa tinha que contribuir com um vultoso dote, provar a idade da filha, que era batizada, de preferência na Sé, e tinha

\footnotetext{
${ }^{350}$ Cf. Anna Amélia Vieira Nascimento. Patriarcado e religião: as enclausuradas clarissas do Convento do Desterro da Bahia, 1677-1890. Salvador: Conselho de Cultura, 1994.
} 
“sangue puro". Depois de um ano de noviciado, cumpridas as exigências do Concílio tridentino, das inquisições dos arcebispos, da certidão de batismo, depois de serem submetidas à votação, recebiam a sentença apostólica, que conferia à jovem noviça o direito de receber o véu preto. Desse grupo de religiosas, elegiam-se para um mandato trienal a maior autoridade do Desterro: as abadessas ${ }^{351}$.

Ser abadessa significava uma autoridade indiscutível sobre as demais religiosas e grande responsabilidade pela ordem social e econômica do convento, por isso nunca o mais alto posto do convento do Desterro foi pacificamente conquistado. As eleições eram acirradamente disputadas, contando, muitas vezes, com a interferência de alguns quadros da administração local e com a estreita vigilância dos arcebispos da Bahia. Aliás, de acordo com a documentação, as interferências do poder local ocorriam também e principalmente no ingresso das religiosas ao Convento.

As religiosas eram escolhidas pelo critério final dos arcebispos ou de seus representantes, mas seguidas vezes S.M. foi solicitada a interferir para a entrada de alguma religiosa mais influente socialmente, motivada por sua família a ocupar o privilegiado lugar de véu preto. É o caso da discórdia ocorrida por volta de 1759, envolvendo José Pires de Carvalho, antigo Secretário de Estado, (avô do Secretário de Estado por ocasião de 1798), e sua irmã Maria do Sacramento, na ocasião abadessa do Desterro. O arcebispo havia representado contra as desarmonias e confusões no convento, ocorridas pelo provimento de um lugar vago de véu preto, originando-se subornos por parte do Secretário de Estado e de sua irmã abadessa ${ }^{352}$.

Um grupo de religiosas apoiava a noviça de véu branco, Clara Custódia, filha de um alfaiate; e outro grupo apoiava a filha menor de idade de José Pires de Carvalho. O arcebispo, nessa ocasião, visitou o convento e foi recebido com hostilidade pela abadessa e desrespeito pelas religiosas, que se opunham à escolha do prelado por Clara Custódio. Não obstante S. M. ter mandado o arcebispo suspender o provimento do lugar de véu preto por tempo indeterminado e advertir que José Pires de Carvalho não se intrometesse nas eleições e pendências religiosas sob o mandato da abadessa sua irmã, a pendência foi resolvida um ano depois quando o filho do Secretário de Estado, José Pires de Carvalho e Albuquerque e sua esposa d. Isabel Joaquina de Aragão conseguiram permissão do mesmo arcebispo para que suas filhas Tereza Josefa

\footnotetext{
${ }^{351}$ Cf. Susan Soeiro. The Social and the Economic Role of the convent: woman and nuns in colonial Brasil, 1677-1800. HAHR, may, 1974, v. 54, no 1.

${ }^{352}$ Cf. Anna Amélia Vieira Nascimento, op.cit., pp. 118-119.
} 
Cavalcanti e Teresa Ana de La Penha Deusdará fossem recebidas em Santa Clara do Desterro de maneira solene e benção de hábitos à entrada de véu preto, assistidas pelo tio de ambas, o frei carmelita João Jesus Maria José.

Situações como essa fizeram com que os prelados ficassem vigilantes acerca do comportamento pouco ortodoxo das religiosas do Desterro. O mais minucioso em sua vigilância foi d. Antônio de Corrêa (11 ${ }^{\circ}$ arcebispo da Bahia, 1780-1802) que, por duas vezes, intrometeu-se nas eleições do Desterro. Em uma delas, em 1786, terminado o período abacial de Margarida Josefa da Conceição, as religiosas inclinadas a um comportamento mais livre resolveram eleger, para a função de Abadessa, Catarina dos Anjos, famosa dentro e fora do convento por sua "relaxação": só frequentava o coro uma vez por ano, na semana santa, e junto com as religiosas que a apoiavam abominavam as deliberações do Arcebispo d. Antônio de Corrêa que objetivavam o recrudescimento nos costumes monacais.

Informado do intuito das religiosas insurretas, d. Antônio conseguiu um breve do cardeal núncio para o impedimento da eleição do Desterro e a designação de uma abadessa de sua escolha ${ }^{353}$. Ana Amélia Vieira Nascimento afirma que Margarida Josefa da Conceição foi abadessa reeleita escolhida pelo prelado, mas no Livro de entrada das religiosas clarissas, Catarina dos Anjos aparece como abadessa eleita no período de 1786-1771. Além disso, no Livro de Notas do período, há o registro de que, em 24 de julho de 1771, o Secretário de Estado José Pires de Carvalho e Albuquerque e sua esposa d. Isabel Joaquina de Aragão celebraram uma escritura com a abadessa Catarina dos Anjos e as demais religiosas do Desterro, perpetuando anualmente seus sentimentos pios à Sant'Ana, por meio de uma festa solene na igreja do convento com música e senhor exposto. Para que a festividade fosse anualmente realizada, o casal outorgava aos cuidados da abadessa a quantia de $400 \$ 000$ reis anuais para que suas devoções fossem perpetuadas $^{354}$.

Seja como for, a oposição desse grupo de religiosas ao arcebispo d. Antônio de Corrêa ocorria porque além de ele ter sido o prelado que mais se dedicou à reforma e ao recrudescimento dos costumes monásticos do Desterro, ele passou a interferir e a denunciar as relações das abadessas do Desterro com a família de Secretários de Estado, os Pires de Carvalho e Albuquerque que, de acordo com suas cartas, eram responsáveis

\footnotetext{
${ }^{353}$ Idem.

${ }^{354}$ APEB, livros de notas, 114, f. 75v.
} 
por muitas das desordens ocorridas no convento ${ }^{355}$. Para o prelado, a maioria das religiosas não ia ao coro e somente umas dez ou doze assistiam a todos os atos da comunidade; algumas não compareciam ao coro nem na semana santa e nem em certas ocasiões rezavam o ofício divino. Além disso, todas queriam frequentar as grades e o mirante todos os dias, pela manhã e pela tarde, com licenças para a entrada de diversas pessoas, sobretudo no período das eleições quando a situação se agravava e vários homens da governação local eram recebidos na clausura ${ }^{356}$.

Outra grande questão polêmica do Desterro, vista por d. Antônio Corrêa como um comportamento abominável, era o número de escravas e servas presentes nas clausuras, mesmo com deliberada proibição papal. De acordo com o relato encaminhado à d. Maria I, cada freira contava com 4 a 6 cativas, de sorte que o número de escravas excedia o de 200, sendo as religiosas apenas 63. Entre elas, a me. Tereza Mariana do Livramento, irmã do Secretário de Estado José Pires de Carvalho e Albuquerque (1798), dispunha de oito escravas e um escravo homem dos seis que viviam no convento ${ }^{357}$.

Situação como essa fez com que o prelado intensificasse suas críticas em razão à desordem nos costumes com a presença desses escravos no Desterro, ao desperdício de despesas, à existência de tantas mulheres ociosas em um mesmo lugar, ocasionando falatório e vícios como os da preguiça, da vaidade, da gula e o pior deles: relações delinquentes entre elas, entre eles e entre todos ${ }^{358}$. Para além da oposição das religiosas do Desterro às críticas e às tentativas de reformas monacais de d. Antônio de Corrêa, a principal polêmica entre eles eram as "usurárias negociações", nos termos do prelado, praticadas pelas religiosas do Desterro.

Várias correspondências foram trocadas entre o prelado e d. Rodrigo de Sousa Coutinho sobre a má fé das religiosas nas transações creditícias, no que dizia respeito ao favorecimento de alguns quadros da administração local no final do século XVIII, em razão da relação de parentesco de alguns deles com as religiosas, especialmente as abadessas desse período, conforme relação abaixo:

\footnotetext{
${ }^{355}$ AHU_CU_CA, Baía, doc. 12142.

${ }^{356}$ Cf. Anna Amélia Vieira Nascimento, op.cit, pp. 152-153.

${ }^{357}$ APEB, Livro de Notas 5, folha 43, 43v.

${ }^{358}$ AHU_CU_CA, Baía, docs: 11516, 11603, 12103.
} 
Relação das Abadessas do Convento da Santa Clara do Desterro da Bahia, final do século XVIII, irmãs do Secretário de Estado e Governo do Brasil.

\begin{tabular}{|c|c|}
\hline Abadessa & Período \\
\hline Teresa Josefa do Paraíso & $1793-1797 / 1797-1802$ \\
\hline Teresa Mariana do Livramento & $1805-1808$ \\
\hline Mariana Francisca do C. de Jesus & $1808-1811$ \\
\hline Antônia de Jesus Maria & Entrou em 1796 e faleceu em 1805. \\
\hline
\end{tabular}

Fonte: Anna Amélia Vieira do Nascimento, op.cit., p. 443 et seq.

Em uma das críticas mais virulentas encaminhadas à metrópole, d. Antônio de Corrêa alertava d. Rodrigo de Sousa Coutinho sobre a penúria em que se encontrava o Desterro no final do século XVIII, causada por transações econômicas como a que ele relatou ao ministro, ocorrida no ano de 1759, e os processos pouco ortodoxos nas eleições das abadessas. Naquele ano, as religiosas do Desterro arremataram o engenho Cazumba, do devedor inadimplente Baltazar de Vasconcelos Cavalcanti, pai da abadessa Catarina dos Anjos, anteriormente executado pela quantia de 7:400\$400, e o venderam imediatamente a José Pires de Carvalho e Albuquerque (Secretário de Estado e Governo do Brasil) e sua esposa pela mesma quantia, em pagamentos iguais de 600\$000 anuais. Contudo, prevaleceram a hipoteca e os juros sobre o Cazumba até sua quitação definitiva, ocorrida quase um século depois. Situação semelhante ocorreu com o engenho Brotas, adquirido em 1765 pelo Secretário de Estado, cuja dívida permaneceu sem quitação até $1844^{359}$.

Na carta denúncia encaminhada a d. Rodrigo de Sousa Coutinho, d. Antônio de Corrêa questionava a necessidade das facilitações do empréstimo e a consequente falta do pagamento anual das dívidas, adquiridas nas duas ocasiões em que os engenhos foram comprados, lembrando ao Ministro que se tratava de uma família muito rica, pois a maior negociação imobiliária ocorrida na Capitania da Bahia no ano de 1769, em uma década de baixíssimos negócios, envolveu a venda de um trapiche por 30:000\$000 efetuada por José Pires de Carvalho e Albuquerque e sua esposa, d. Isabel Joaquina de

\footnotetext{
${ }^{359}$ Cf. Anna Amélia Vieira do Nascimento, op.cit, pp. 264-274. APEB, Livro do Tombo, $4^{\circ}$, f. 99.
} 
Aragão, ao capitão e homem de negócio Teodósio Gonçalves da Silva e sua mulher d. Ana Luíza de Queirós e Silva ${ }^{360}$.

$\mathrm{Na}$ lógica do prelado, com o dinheiro da venda do trapiche, com a herança do principal morgado da Capitania da Bahia e o morgado dos Pires de Carvalho e Albuquerque, herdados pelo Secretário de Estado e Governo do Brasil no final do século XVIII, a família tinha cabedal suficiente para quitar as dívidas contraídas com o Desterro por seus parentes para a compra dos dois engenhos. Ademais, d. Antônio de Corrêa afirmou a d. Rodrigo sobre a má vontade da abadessa Tereza Josefa do Paraíso em cobrar as dívidas do Secretário de Estado seu irmão, pois a seu ver, as religiosas do convento estavam muito mais preocupadas em suas projeções pessoais nas alianças econômicas com seus parentes do que com a boa ordem moral e econômica do convento $^{361}$.

O prelado sugeriu que d. Rodrigo tomasse as mesmas medidas de 1774, quando o então arcebispo d. Joaquim Borges de Figueroa constatou a mesma situação de penúria e d. Maria I, na tentativa de sanar as despesas do convento, proibiu por Carta Régia que o número de religiosas do convento excedesse 50 e designou a criação de uma nova contadoria para a inspeção dos livros de contabilidade e a recuperação das finanças do Desterro, que só entrou em vigor na última década do século XVIII, sob a direção do procurador Manoel José Vilella de Carvalho, considerado pelo governador como um homem de boa fé no comércio e ajudante de ordens do governo junto com o Secretário de Estado José Pires de Carvalho e Albuquerque, alvo da denúncia do arcebispo e irmão das abadessas eleitas e reeleitas na época ${ }^{362}$.

A demonstração contábil realizada naquela década foi visivelmente arranjada para demonstrar à Rainha que os negócios administrativos do convento estavam corretos, convenientemente geridos, em regulares condições financeiras, inclusive, para receber novas religiosas - para além de desviarem a vigilância do prelado e das autoridades régias sobre as transações financeiras do convento, a abadessa e o procurador prospectavam com a entradas de novas religiosas e, consequentemente, de novos dotes para o acréscimo do patrimônio do Desterro, que podiam ultrapassar a quantia de 2:000\$000.

\footnotetext{
${ }^{360}$ Cf. Alexandre Vieira Ribeiro, op.cit.

${ }^{361}$ Cf. Anna Amélia Vieira do Nascimento, idem.

${ }^{362}$ Ibidem, p. 320.
} 
Como escrevera d. Antônio de Correa a d. Rodrigo de Sousa Coutinho, a situação do Desterro, no entanto, era outra, pois no decorrer dos anos, a sangria dos capitais e dos juros não pagos nem cobrados, em razão da importância social de seus devedores, era de fato uma situação abusiva e extremamente perniciosa para o equilíbrio das rendas e despesas do convento, tanto mais que o percentual de empréstimos efetuados pelo Desterro na última década do século XVIII diminuiu consideravelmente em relação à década anterior ${ }^{363}$. Razão pela qual em 1797, d. Rodrigo de Sousa Coutinho pediu esclarecimentos ao governador da Capitania da Bahia, d. Fernando José de Portugal e Castro, sobre as razões pelas quais as dívidas dos senhores de engenho com o Desterro não eram cobradas nem executadas na justiça.

O governador da Bahia, com sua peculiar ironia, afirmou a d. Rodrigo de Sousa Coutinho que prorrogar a quitação da dívida dos senhores de engenho por décadas não era novidade dos tempos nem exclusividade da família Pires de Carvalho e Albuquerque, que S. M. tinha nas ações do então Secretário de Estado e Governo do Brasil, José Pires de Carvalho e Albuquerque, as mais pias demonstrações de fidelidade à Coroa. Tanto mais que d. Fernando lembrou a d. Rodrigo que no início de seu governo na Bahia, José Pires de Carvalho e Albuquerque emprestou a Real Fazenda a quantia de 123 mil cruzados; em 1796, o Secretário de Estado aparece como um dos que emprestou “gratuitamente" 20:000\$000 para o preparo e a expedição da Real Esquadra que estava no porto da Bahia para comboio; e em 1798, José Pires de Carvalho e Albuquerque apareceu entre os que colaborou substancialmente para o empréstimo de 3 milhões de cruzados aberto por edital publico em 1797, embora o empréstimo não tenha atingido o montante exigido, pois de acordo com d. Fernando essa era provavelmente a quantia que circulava em toda a Capitania da Bahia ${ }^{364}$.

$\mathrm{O}$ argumento do governador procurou demonstrar o impasse naquele fim de século das "usurárias negociações" praticadas pelo Desterro com importantes senhores de engenho, pois cobrar e executar essas dívidas na justiça poderia, como se viu, comprometer a produção para exportação da capitania da Bahia e, no limite, as finanças da própria Coroa que se beneficiava constantemente dos empréstimos gratuitos feitos por alguns dos maiores devedores do Desterro, como o próprio José Pires de Carvalho e Albuquerque. Para Anna Amélia Vieira do Nascimento, o Arcebispo não percebia que:

${ }^{363}$ AHU_CU_CA, Baía, doc. 19194: “Officio do Arcebispo D. Fr. António Corrêa para D, Rodrigo de Sousa Coutinho, em que lhe presta varias informações sobre os conventos das freiras das freiras da Soledade e do Desterro. Bahia. 28 de fevereiro de 1799".

${ }^{364}$ BN, Sessão de Manuscritos, MS-512, II, 33, 18, 74. 
"seria difícil a oposição a esse grupo, pois as próprias freiras estavam inseridas e enquadradas nessa sociedade, e delas dependiam. Eram seus próprios irmãos, pais, parentes que as asfixiavam, e tão conceituados socialmente que somente depois de suas mortes a administração do mosteiro aventurava-se nas cobranças e execuções. Vedados os caminhos da justiça para o recebimento das dívidas atrasadas, somente lhes restava o ingresso de novas religiosas para o acréscimo do seu patrimônio" ${ }^{365}$.

Talvez seja por essa razão que nenhuma medida tenha sido efetivamente tomada quanto ao pagamento das dívidas ao Desterro, e d. Fernando José de Portugal e Castro acabou apoiando os vários apelos das clarissas, sobretudo da abadessa do Convento, irmã de José Pires de Carvalho e Albuquerque, à D. Maria I, a fim de receberem mais religiosas para o crescimento do patrimônio do convento, por meio das dotações e do adiantamento de legítimas. No entanto, o Conselho Ultramarino, d. Rodrigo de Sousa Coutinho e o próprio d. Antônio de Côrrea, insistiram na necessidade de reformar os conventos e, sobretudo, limitar o número de religiosas nos conventos, especialmente no Desterro, sob a argumentação de que com a desordem do Desterro não haveria meios de sustentá-las ${ }^{366}$.

A questão do impasse era se a entrada de novas religiosas no Desterro significaria o aumento do percentual dos empréstimos concedidos, pois no período do arcebispado de d. José Botelho de Matos (1741-1760), quando entraram 49 freiras, o percentual dos créditos registrados não passou de 15,46\% do total dos empréstimos a juros realizados pelo Desterro. Em compensação, nos arcebispados de d. Manuel de Santa Inês, de d. Joaquim Borges de Figueiroa e do próprio d. Antônio de Correa (17621802) o percentual de empréstimos cresceu consideravelmente com a entrada de apenas 12 religiosas: $41,30 \%$ em quarenta $\operatorname{anos}^{367}$.

$\mathrm{O}$ argumento a favor da entrada de novas religiosas no Desterro, de d. Fernando José de Portugal e Castro, baseou-se no fato de o mercado de crédito baiano ser altamente concentrado $^{368}$, e que a questão não era o número de novas religiosas, mas o nível social delas, pois no arcebispado de d. Antônio de Corrêa, das quatro novas religiosas que entraram no Desterro, a que deu entrada em 1796, era outra irmã do Secretário de Estado e da abadessa do convento, Antônia de Jesus Maria.

\footnotetext{
365 Anna Amélia Vieira do Nascimento, op.cit., pp. 321-322.

${ }^{366}$ Idem, pp.330-332; AHU_CU_CA, Baía, 19535, 19536 e 19537.

${ }^{367}$ Idem.

${ }^{368}$ Cf. Maria José Mascarenhas Rapassi, op.cit.
} 
Além disso, cumpre destacar que corroborou para o posicionamento de $\mathrm{d}$. Fernando José de Portugal e Castro a favor das clarissas do Convento do Desterro a intransigência do Arcebispo da Bahia em relação às reformas monacais e às "usurárias negociações", que desagradava cada vez mais o governador da capitania da Bahia, o Secretário de Estado e Governo do Brasil e outros importantes homens da administração local, que desejavam que ao menos uma de suas filhas fosse para o convento de maior prestígio social e econômico da capitania da Bahia.

Em 1799, d. Antônio Correa recusou a entrada de Anna de Amorim e Castro, filha do Juiz de Fora da Vila de Cachoeira, Joaquim de Amorim e Castro, no Convento do Desterro, encaminhando-a ao Convento de Nossa Senhora da Lapa ${ }^{369}$. No mesmo ano, d. Antônio de Correa criticou a medida de d. Fernando em estabelecer um hospital no edifício do antigo colégio dos Jesuítas, que ele pleiteava para a instituição de um Seminário $^{370}$, e tentou interceder sobre a pena dos acusados do crime de sedição deflagrado em agosto de 1798 e nas graças e honrarias que os denunciantes deveriam receber $^{371}$.

As posturas do Arcebispo da Bahia foram determinantes para que d. Fernando José de Portugal e Castro se empenhasse em convencer as autoridades régias sobre a necessidade premente de se autorizar a entrada de novas religiosas para a boa economia do Desterro. Assim, a despeito das tentativas de reforma do arcebispo apoiado por d. Rodrigo de Sousa Coutinho, o governador da capitania da Bahia novamente saiu-se vitorioso dessa disputa política, pois a coroa portuguesa autorizou a entrada de novas religiosas em 1799. Após o falecimento de d. Antônio de Corrêa, em junho de 1802, nos livros de entradas das religiosas do Desterro, somados os anos da Sé vacante com os do arcebispado de d. José de Santa Escolástica, 1802-1814, durante boa parte do mandato

\footnotetext{
${ }^{369}$ AHU_CU_CA, Baía, doc. 19536. “Officio do Arcebispo D. Fr. António Corrêa para D. Rodrigo de Sousa Coutinho, sobre a admissão de educandas e recolhidas nos conventos de religiosas, informando acerca da entrada de D. Anna de Amorim e Castro para o de N. S. da Lapa. Bahia, 4 de novembro de 1799".

${ }^{370}$ AHU_CU_CA, Baía, docs. 19474-19475: “Officios (2) do Arcebispo D. Fr. António Corrêa para D. Rodrigo de Sousa Coutinho, no qual se refere á resolução do Governador de estabelecer um hospital no edifico do antigo Collegio dos Jesuítas, anteriormente destinado a Seminário, cuja fundação diz ser absolutamente necessária. Bahia, 21 de setembro de 1799".

${ }^{371}$ AHU_CU_CA, Baía, doc. 19222: “Officio do Arcebispo D. Fr. António Corrêa para D. Rodrigo de Sousa Coutinho, em que se refere á devassa a que procedera por causa da denuncia do Padre José da Fonseca Neves, contra o cirurgião Cypriano Barata e Marcellino António de Sousa, que accusava de libertinos e diffamadores da religião. Bahia, 23 de março de 1799”. AHU_CU_CA, Baía, doc. 19223: “Officio do Arcebispo D. Fr. António Corrêa para D. Rodrigo de Sousa Cō̄inhōo, em que se refere ás devassas a que se procedera contra vários indivíduos accusados de publicarem folhetos sediciosos e tramarem uma conspiração, ao seu julgamento e ás recompensas que se deveriam conceder aos denunciantes Joaquim José da Veiga e Joaquim José de Sant'Anna”.
} 
abacial das irmãs de José Pires de Carvalho e Albuquerque, deram entrada no Desterro 26 novas religiosas. Década na qual o Desterro quase duplicou o percentual de concessão de empréstimos: 1790-1800: 7,74\%, 1800-1810: 12,90\%.

Algumas dívidas das principais famílias de senhores de engenho levaram até 196 anos para serem quitadas, sendo que em alguns casos não há registro nem do pagamento dos juros da dívida. Uma das razões para essa situação, como se viu, é o fato de a maioria dos mutuários terem relações de parentescos com as religiosas, tornando o mercado de crédito baiano altamente concentrado, pois qualquer pessoa podia pedir crédito, mas poucas conseguiam de fato. A documentação demonstra que dos $10 \%$ dos maiores empréstimos efetuados da segunda metade até o final do século XVIII (setenta e nove), vinte e oito foram realizados por instituições como a Misericórdia e o Desterro $^{372}$.

A essa altura não parece exagerado sugerir que a postura da coroa portuguesa em fortalecer a posição política do governador da Bahia muito provavelmente ocorreu em razão das alianças políticas que d. Fernando construiu no âmbito local com alguns desembargadores do Tribunal da Relação da Bahia e a corporação dos enteados que, além de serem proprietários dos escravos da Conjuração Baiana de 1798, homens de consideráveis cabedais, ocupavam cargos estratégicos da administração, sendo que o Secretário de Estado e Governo do Brasil, como se viu, era um importante credor para a Fazenda Real. A documentação sugere que essa rede de poder passava ao largo da Câmara Municipal que, depois de 1796, manteve-se muito mais afinada com a perspectiva política d. Rodrigo de Sousa Coutinho, cujas reformas poderiam comprometer o funcionamento do sistema que tanto lhes favorecia.

Trabalhos recentes têm destacado o papel das Câmaras Municipais, sobretudo as de Salvador e do Rio de Janeiro, como o mais importante núcleo de intervenção metropolitana no âmbito local, incidindo sobre diversos aspectos da vida cotidiana dos habitantes da urbe e de seu termo, sobretudo nos níveis da produção, circulação e consumo de bens materiais e serviços, bem como da comercialização das mercadorias de importação e exportação ${ }^{373}$. A postura das Câmaras Municipais, em termos práticos,

\footnotetext{
${ }^{372}$ APEB, Livro de notas, 1,2,3, e Ofícios de Salvador, livro 103, folha 115v.

${ }^{373}$ Cf. Maria Fernanda Bicalho. A cidade e o Império: o Rio de Janeiro na dinâmica colonial portuguesa, séculos XVII e XVIII. Rio de Janeiro: Civilização Brasileira, 2002. BOXER, Charles. Conselheiros municipais e irmãos de caridade. In: Maria Beatriz Nizza da Silva. O Império Marítimo português. Trad. Anna Olga de Barros Barreto. São Paulo: Cia das Letras, 2002; Avanete Pereira Sousa. Poder local, cidade e atividades econômicas: Bahia, século XVIII. Tese de Doutorado, programa de Pós-Graduação em História Econômica, FFLCH/USP, 2003.
} 
eram tidas por relativamente autônomas e coercitivas, e, justamente por isso, incitavam infrações de toda sorte.

A análise das atas da Câmara de Salvador na última década do século XVIII demonstra não só o aumento das denúncias de prática de contrabando de farinha, tabaco e a venda de carne em lojas abertas por parte da corporação dos enteados e sua rede de poder, bem como a intensificação do questionamento desse grupo sobre as ações da Câmara e suas incidências sobre o mercado urbano, especialmente os talhos, os currais e o comércio da carne ${ }^{374}$, cuja oposição fez-se mais veemente entre grupos privilegiados do ponto de vista comercial por usufruírem de monopólios e serviços estatais ${ }^{375}$.

Não parece ser coincidência o fato de que o comerciante, Procurador da Câmara de Salvador em Lisboa e Familiar do Santo Ofício, Jacinto Dias Damásio tenha assinado uma denúncia grave de contrabando contra o administrador do curral, Pedro Francisco de Castro, e tenha sido chamado a testemunhar durante as investigações da Conjuração Baiana de 1798, por ter sido acusado pelo então suspeito Luiz Gonzaga das Virgens "em Caza delle testemunha tinha entrado e amizade hum certo Manoel João, ou por outro nome João da Sylva de Narbona, comprando delle varias fazendas para seos negoceos "376. Além disso, entre os maiores opositores às posturas da Câmara de Salvador, estão alguns dos proprietários dos escravos entregues à justiça da Conjuração Baiana de 1798, que antes de d. Rodrigo de Sousa Coutinho assumir a Secretaria de Estado dos Negócios da Marinha e Domínios Ultramarinos, em 1796, também foram vereadores. Como é o caso de Bernardino de Sena e Araújo, Caetano Maurício Machado, Frutuoso Vicente Viana (pai de Francisco Vicente Viana) e o próprio José $\underline{\text { Pires de Carvalho e Albuquerque }}^{377}$.

Significativa nesse sentido é a atuação de Adriano de Araújo Braga - negociante da Bahia e natural do arcebispado de Braga - ${ }^{378}$, homem ligado ao grupo do Secretário de Estado, Procurador da Câmara de Salvador, durante os anos de 1795-96, que foi

\footnotetext{
${ }^{374}$ APEB, Colonial, Fundo Governo Geral/Governo da Capitania. Registro de Correspondência expedida para o Rei, Maço 183, folhas 274, 275, 275v: Devaça pelos factos constantes da Representação do Procurador do Concelho, do anno passado, Jacinto Dias Damásio contra o Administrador do Curral, Pedro Francisco de Castro, mandando notificar para deporem nella tanto os Procuradores dos annos antecedentes e principais Negociantes desta Cidade, como os Officiaes e Artífices do Curral e Assougue, Creadores e Marchantes.

${ }^{375}$ Avanete Pereira Sousa, op.cit., p. 298.

${ }^{376}$ Cf. ADCA, vol. 1, pp. 58-59: "Jacinto Dias Damásio homem branco cazado morador na Praia desta Cidade que vive do seo negocio de idade que disse ser de quarenta anos testemunha jurada aos Santos Evangelhos em hum Livro delles que pos sua mão direita prometeo dizer a verdade".

${ }^{377}$ Cf. Affonso Ruy. História da Câmara Municipal da Cidade de Salvador. Salvador: Câmara Municipal de Salvador, $3^{\text {a }}$ edição aumentada, 2002, pp. 350-353.

${ }^{378}$ AHU_CU_CA_Baía, Caixa 79, doc. 15268.
} 
nomeado por d. Fernando José de Portugal e Castro como administrador do Celeiro Público - órgão responsável pelo abastecimento do mercado urbano -, no final de 1796, permanecendo no cargo até 1800 , quando o regimento previa o mandato de apenas um ano "sem ordenado e só com a glória do bom cidadão 379 .

Cumpre destacar que ainda que o Celeiro Público tenha sido criado em 1785, durante o governo de d. Rodrigo José de Menezes, ele começou a funcionar efetivamente em 1788, no prédio da Intendência da Marinha e Armazéns Reais, obrigando as embarcações de mantimentos que chegavam e saíam do porto de Salvador a vendê-los no celeiro a preço estabelecido e pagar a "contribuição de 20 réis por alqueire de farinha, arroz, milho e feijão ${ }^{, 380}$. Em termos práticos, além de os Almotacés e a Câmara Municipal terem perdido o controle do comércio da farinha, restando-lhes o não menos importante comércio da carne, foi instituído o monopólio no preço dos alimentos e o pagamento de mais uma taxa sobre os gêneros comestíveis taxas que já tinham sido abolidas em Lisboa pelo Alvará de 21 de fevereiro $1765^{381}$.

Desde então, foram várias as solicitações para que esse Alvará fosse estendido à cidade de Salvador, intensificadas nos anos em que Adriano de Araújo Braga esteve à testa do Celeiro Público, pois mesmo depois de ele ter liberado a taxa dos alimentos ali vendidos, manteve-se a cobrança da taxa para as embarcações. As queixas recaíam sobre o fato de ser o Secretário de Estado e Governo do Brasil, José Pires de Carvalho e Albuquerque, quem cobrava e recebia as taxas das embarcações. A respeito da denúncia que qualificava a cobrança da taxa cobrada por abusiva, d. Fernando José de Portugal e Castro escreveu a d. Rodrigo em 12 de março de 1798:

"sobre os direitos que pagam as embarcacoens que sahem deste Porto, sobre o que me ocorre a ponderar a V. Exa. que o Secretário deste Estado está authorizado pelo Capítulo $5^{\circ}$ do Meu Regimento, datado de 28 de julho de 1669, para perceber três mil réis pelas licenças de cada Navio e oitocentos réis pelos Barcos de pescaria [...]", ,382.

D. Fernando terminou mais uma defesa do Secretário, afirmando que "os Suplicantes se queixão sem motivo justo e até com ignorância das Ordens, [pois] o que verifico [é] que o actual Secretário deste Governo cobra o mesmo que cobrarão os seus

\footnotetext{
${ }^{379}$ Cf. O Celleiro da Bahia. Revista do Instituto Geográfico e Histórico da Bahia, Ano III, Vol. III, nº. 10, Dezembro de 1896. Há uma cópia manuscrita desse documento na Biblioteca Nacional sob o título de “Discurso sobre o celeiro público da Bahia, assinado por um anônimo”, BN, II, 33, 24, 40. Agradeço a indicação desse documento e as informações sobre o Celeiro Público a Afrânio Mário Simões Filho.

${ }^{380}$ Cf. Afrânio Mário Simões Filho, op.cit.

${ }^{381}$ Cf. Stuart. B. Schwarz, op.cit.; Afrânio Mário Simões Filho, op.cit.; Jude B. Barickman, op.cit.

382 BN, Sessão de Manuscritos, II-33, 19, 24.
} 
antecedentes 383 . O fato é que a Coroa estende o Alvará de 1765 à cidade de Salvador em 1799, quando Adriano de Araújo Braga conseguiu que os rendimentos do Celeiro Público rendessem mais do que o costume ${ }^{384}$.

As atitudes de d. Fernando José de Portugal e Castro demonstram que sob a aparente afabilidade, contemporização e frouxidão de caráter, constantemente retratada por seus contemporâneos, havia um projeto político que se desenhava naqueles anos finais do século XVIII, no qual o governador da capitania da Bahia agia em comunhão com alguns Ministros do Tribunal da Relação da Bahia e um grupo de notáveis que, apesar de protagonizarem muitas contendas e serem constantemente denunciados por prática de contrabando, enriquecimento ilícito e desordens administrativas, eram muito importantes para a manutenção do poder da coroa portuguesa na época.

Muito da postura de d. Fernando José de Portugal e Castro e da própria coroa portuguesa se deve ao fato de que os homens que compunham a corporação dos enteados estavam direta ou indiretamente ligados ao controle da produção econômica para exportação na capitania da Bahia naquele final de século, seja como senhores de engenho, seja como credores e tomadores de crédito, seja como sócios no tráfico de escravos, seja como sócios na arrematação do contrato dos dízimos reais. Situação que dependia da manutenção das regras do jogo político entre a coroa portuguesa e sua principal colônia ${ }^{385}$, que passou a ser ameaçada após d. Rodrigo de Sousa Coutinho assumir a Secretaria de Estado dos Negócios da Marinha e Domínios Ultramarinos, em 1796.

\footnotetext{
${ }^{383}$ Idem

${ }^{384}$ Ibidem, p. 569.

385 Por ocasião da Inconfidência Mineira de 1789, Kenneth Maxwell demonstra que a legislação vigente era feita para arrecadar de forma desproporcional impostos baseados no comércio de exportação e parte significativa da renda desse comércio ficava empatada em atividades improdutivas. Além disso, o sistema de contratos e monopólios alienava possibilidades de ganho para um grande número de comerciantes, que aspiravam ampliar seus cabedais e suas participações políticas. Maxwell não foi o único a chegar a tal constatação, mas foi o primeiro a relacionar o impacto das reformas de d. Rodrigo de Sousa Coutinho à Inconfidência Mineira de 1798. Cf. Kenneth Maxwell. A Devassa da Devassa. A Inconfidência Mineira: Brasil e Portugal: 1750-1808. Rio de Janeiro: Paz e Terra, 1977.
} 


\section{Capítulo 2}

\section{Tempos de Contestação: 1797-1798}




\subsection{Os impactos da política reformista de d. Rodrigo de Sousa Coutinho na capitania da Bahia no final do século XVIII}

D. Rodrigo de Souza Coutinho é reconhecido pela historiografia luso-brasileira como um dos maiores estadistas portugueses do final do século XVIII. Nascido em 1755, teve uma formação privilegiada no Colégio dos Nobres e na Universidade de Coimbra que haviam sido reformadas por seu padrinho, Sebastião José de Carvalho e Melo, o marquês de Pombal (1699-1782). Exerceu funções diplomáticas em Turim, durante 17 anos, como enviado extraordinário e ministro plenipotenciário na Corte de Sardenha. Acompanhou de perto os rumos da Revolução Francesa e viveu o pulsar das luzes, forjando e consolidando seu pensamento sobre matérias estratégicas ao desempenho governativo da coroa portuguesa no final do século XVIII em diante: sobretudo os assuntos fiscais, fazendários e diplomáticos ${ }^{386}$.

Suas ideias ilustradas e reformistas ganharam força política e operacionalidade durante os anos em que esteve à testa da Secretaria de Estado da Marinha e Domínios Ultramarinos e do Erário Régio, entre 1796 e 1803, cuja atuação, muitas vezes exorbitou o âmbito restrito de seu cargo ${ }^{387}$. Isso se deve ao fato de que, no final do século XVIII, o Brasil desempenhava papel crucial no equilíbrio estrutural do comércio externo português ao mesmo tempo em que se intensificavam os argumentos ilustrados para a revisão do papel das colônias na formação dos impérios europeus e se acirravam as disputas diplomáticas entre as grandes potências europeias ${ }^{388}$.

Assim, logo no início de seu mandato ministerial, d. Rodrigo dedicou especial atenção à situação financeira em que se encontrava a coroa portuguesa, que naquele final de século assistia a morosidade na cobrança de impostos, quebra nas receitas

\footnotetext{
${ }^{386}$ Cf. José Luís Cardoso (Org). A economia política e os dilemas do império luso-brasileiro (17901822). Lisboa: Comissão Nacional para as comemorações dos Descobrimentos Portugueses, 2001, pp. 63109. Sobre d. Rodrigo de Sousa Coutinho ler, sobretudo: Andrée Mansuy-Diniz Silva. Portrait d'um homme d'État: D. Rodrigo de Souza Coutinho, Conde de Linhares, 1755-1822. Paris: Centre Culturel Calouste Gulbenkian, 2006, 2 vols.

${ }^{387}$ Idem, p. 66. José Luís Cardoso demonstra a ambição política de d. Rodrigo de Sousa Coutinho nas várias incursões que ele fez em domínios gerais do governo da coroa portuguesa, que exorbitavam o âmbito de seu cargo.

${ }^{388}$ Sobre a inserção do Brasil na evolução do Sistema Colonial Português, ler, apesar de divergirem no tocante ao quadro teórico e metodológico, sobretudo: Caio Prado Junior. A formação do Brasil contemporâneo. São Paulo: Publifolha, 2000; Fernando Antônio Novais. Portugal e Brasil na Crise do Antigo Sistema Colonial (1777-1808). São Paulo: Hucitec, 2006, 9ª Edição; Kenneth Maxwell. A devassa da devassa: a inconfidência mineira, Brasil-Portugal, 1750-1808. Rio de Janeiro, Paz e Terra, $2^{\circ}$ ed. 1978; Maria de Lourdes Viana Lyra. A utopia do poderoso Império. Portugal e Brasil: bastidores da política (1798- 1822). Rio de Janeiro: Sette Letras, 1994; Stuart Schwarz, op.cit.; Valentim Alexandre. Os Sentidos do Império: Questão Nacional e Questão Colonial na Crise do Antigo Regime Português. Porto: Edições Afrontamento, 1993.
} 
alfandegárias e acréscimo significativo com as despesas extraordinárias para questões militares e dinamização da marinha portuguesa. Propôs a dinamização da política e da economia do império português, cuja síntese de seu pensamento político e econômico é sem dúvida a Memória sobre os melhoramentos dos domínios de sua majestade na América, provavelmente escrita entre os anos de 1797 e 1798, que nos permite realizar a conexão entre os projetos de reforma fiscal e de reforma do sistema colonial tanto na superação das dificuldades financeiras daqueles anos - as premências da conjuntura como na rearticulação das relações entre metrópole e colônia - o domínio das estruturas $^{389}$.

É assente na historiografia luso-brasileira que a visão de império elaborada por d. Rodrigo de Sousa Coutinho fundamenta-se sobre dois princípios: unidade política e dependência econômica. O primeiro princípio baseava-se no "natural" enlace entre todas as províncias da monarquia portuguesa, que eram partes de um todo com um centro europeu, para justificar toda e qualquer medida necessária a garantir a indissolubilidade do império como unidade política de referência e afastar o risco de processos de independência política, como o que havia ocorrido na América do Norte em $1776^{390}$. Para tanto, d. Rodrigo de Sousa Coutinho propôs um programa de ação que necessitava da cooperação e tomada de consciência sobre o princípio dos "nexos indissolúveis" das partes do império português pelos mais altos funcionários administrativos da colônia portuguesa na América ${ }^{391}$.

Em relação ao princípio da dependência econômica, a preocupação de $\mathrm{d}$. Rodrigo de Sousa Coutinho foi a de elaborar um conjunto normativo que desestimulasse, sobretudo, o estabelecimento de relações econômicas entre as partes do império português, sem a intervenção e o controle do núcleo metropolitano: "as relações de cada domínio ultramarino devem em recíproca vantagem ser mais ativas $e$ mais animadas com a metrópole do que entre si ${ }^{\text {"392 }}$. Apesar de propor a diversificação da produção colonial, d. Rodrigo de Sousa Coutinho tinha por objetivo precípuo

\footnotetext{
${ }^{389}$ José Luís Cardoso, op.cit; Bruno Aidar. Uma substituição luminosa: tributação e reforma do Antigo Regime português em D. Rodrigo de Souza Coutinho ao final do século XVIII. Nova Economia: Belo Horizonte, 21 (1), pp. 137-156, janeiro-abril de 2011.

390 Fernando Antônio Novais demonstra o dilema das reformas propostas por d. Rodrigo de Sousa Coutinho, no período de d. Maria I e do príncipe Regente, d. João VI: a difícil manutenção do ponto de equilíbrio entre a assimilação do pensamento crítico das Luzes e a contenção de seus efeitos contestatórios do absolutismo e do sistema colonial. Fernando A. Novais, op.cit., p. 224.

${ }^{391}$ José Luís Cardoso, op.cit., p. 80.

392 D. Rodrigo de Sousa Coutinho. Memória sobre o melhoramento dos domínios na América (1797). Brasília, Coimbra, 1949, p. 411.
} 
dinamizar o que ele considerava ser a vocação econômica da colônia brasileira: a agricultura para exportação, preservando o Brasil como um mercado reservado para os produtos manufaturados portugueses ${ }^{393}$.

Para Fernando Novais, a peculiaridade das propostas de d. Rodrigo de Sousa Coutinho sobre a situação de Portugal e suas colônias no contexto do Antigo Sistema Colonial tornou-se uma importante ideologia para superar as contradições do pacto colonial naquele tumultuado final de século e diminuir a desproporção entre a metrópole e seus domínios, agravada pela defasagem econômica do império português em relação às potências europeias mais desenvolvidas ${ }^{394}$. Valentim Alexandre, por sua vez, entende que essa ideologia não representou qualquer alteração substancial na prática política de fomento da coroa portuguesa desde o consulado pombalino, representando o aprimoramento do Sistema Colonial na medida em que o conjunto normativo proposto por d. Rodrigo de Sousa Coutinho nos domínios ultramarinos, em especial no Brasil, tinha como objetivo central a defesa dos interesses metropolitanos, uma vez que o aumento da produção de gêneros coloniais beneficiaria a burguesia mercantil portuguesa, que detinha o exclusivo do transporte da América para a Europa, e a

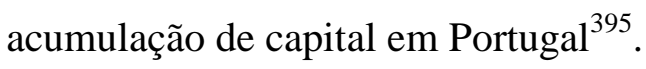

Seja como for, o programa de reformas de d. Rodrigo de Sousa Coutinho incluía a redução da carga fiscal que foi associado a uma vasta gama de atividades econômicas em curso no Brasil. Como leitor do abade Raynal e de outros autores iluministas que apresentaram reflexões críticas sobre a natureza do comércio colonial e a necessidade de sua reforma, d. Rodrigo sabia que o velho "pacto colonial", o sistema baseado em contratos negociados e privilégios exclusivos não poderia ser mantido para sempre. Preocupava-lhe, em especial, a lógica do regime fiscal e certas políticas que se iniciaram essencialmente pela voracidade em relação às riquezas coloniais ${ }^{396}$. Como leitor de Adam Smith, ele também estava bem informado sobre os sólidos princípios que os governos deviam seguir no domínio da política fiscal, nomeadamente no que

\footnotetext{
393 Ibidem. Valentim Alexandre, op.cit., pp. 84-89; Fernando Antônio Novais, op.cit., pp. 227-228. Cumpre destacar que Fernando Novais e Valentim Alexandre, ainda que com pressupostos teóricometodológicos distintos, entendem que o projeto de "desenvolvimento integrado" proposto por d. Rodrigo de Sousa Coutinho tinha por objetivo a interdependência dos domínios ultramarinos para a preservação do Sistema Colonial.

${ }^{394}$ Fernando Antônio Novais, op.cit., p. 234.

${ }^{395}$ Valentim Alexandre, op.cit., p. 86.

${ }^{396}$ Cf. Bruno Aidar, op.cit., José Luís Cardoso, op.cit.
} 
dizia respeito às regras universais de segurança e conveniência que não deveriam estar em desacordo com as necessidades e anseios daqueles que pagavam tributos ${ }^{397}$.

Assim, com o objetivo de "dotar o Brasil de uma estrutura econômica $e$ financeira modernizada e devidamente adaptada às necessidades do modelo de desenvolvimento português", d. Rodrigo de Sousa Coutinho adotou medidas "que punham em risco certas prerrogativas do regime colonial mercantilista"398. Estão entre as medidas que afetariam e promoveriam reformas no sistema de tributação no Brasil: redução dos direitos de entrada e isenção para vinhos, azeite, aço, ferro e manufaturas do reino; supressão e redução de direitos sobre a entrada de escravos; abolição do regime de exclusivos e de contratos monopolistas (designadamente do sal e da pesca da baleia) e sua transferência para a administração da Coroa; redução da metade do quinto do ouro ${ }^{399}$.

Tais medidas tiveram reações nos dois lados do Atlântico. Valentim Alexandre nos mostra que tanto a abolição dos estancos do sal e da pesca da baleia, pelo Alvará de 24 de Abril de 1801, como a extinção do sistema de arrecadação dos impostos por contratadores, que deveriam ser substituídos pela cobrança direta da própria administração, fortaleceriam as finanças da coroa portuguesa, mas, em contrapartida, prejudicariam “capitalistas metropolitanos e também alguns brasileiros" há muito ligados a essas atividades. Para o autor, tais medidas refletiam a lógica de d. Rodrigo de Sousa Coutinho, a de sacrificar alguns interesses em benefício do funcionamento geral do sistema e do comércio metropolitano em seu conjunto ${ }^{400}$.

Justamente porque d. Rodrigo de Sousa Coutinho atribuía o colapso da monarquia francesa à situação fiscal, sua oposição aos monopólios, à concessão da coleta de impostos a particulares, e seu fervoroso apoio a uma administração eficiente surgiram da crença na necessidade de reformas para evitar uma crise da mesma natureza em Portugal. Afirmava que "a boa administração da Real Fazenda contribuiria muito para a conservação dos grandes domínios ultramarinos" $" 401$.

O programa reformista na agricultura apoiava-se principalmente na redução dos impedimentos fiscais que oneravam a produção. Além das sugestões de construir as

\footnotetext{
397 José Luís Cardoso \& Alexandre Mendes Cunha. Discurso econômico e política colonial no Império Luso-Brasileiro (1750-1808). Tempo, Rio de Janeiro, Número 31, 2012, pp. 65-88.

${ }^{398}$ José Luís Cardoso (Org.). A economia política e os dilemas do império luso-brasileiro, op.cit., pp. 8485.

${ }^{399}$ Idem. Kenneth Maxwell. A devassa da devassa, op.cit., p. 238-239.

${ }^{400}$ Valentim Alexandre, op.cit., pp. 86-87.

${ }^{401}$ Kenneth Maxwell, op.cit.
} 
estradas para comunicação interna, dos canais de navegação e de rega, de utilizar o estrume como adubo e de abolir os foros e os morgados, havia a necessidade de diminuir o dízimo "que sendo proporcional ao produto em bruto, e não à renda, é um imposto que, nem as nossas terras, nem as de nenhum outro país, podem sofrer" ${ }^{\text {"402 }}$.Em sugestivo trabalho, Bruno Aidar afirma ser a partir do enquadramento geral reformista relacionado ao fomento da agricultura, pela moderação dos tributos, e à crítica dos contratadores que se deve compreender as considerações de D. Rodrigo de Souza Coutinho a respeito dos dízimos.

$\mathrm{O}$ argumento de d. Rodrigo de Sousa Coutinho para a extinção dos dízimos residia no fato de que nem o dízimo nem as jugadas faziam mais parte da renda do Soberano. A ideia era que esses impostos fossem substituídos por um imposto territorial único para que a arrecadação da coroa portuguesa aumentasse e diminuísse as diferenças entre as pessoas extremamente ricas e as pobres dentro da Igreja. A seu ver, "a natureza da taxação depende das origens da riqueza da sociedade", pois naquela conjuntura do final do século XVIII, a "boa taxação" significava "distribuir proporcionalmente por estas primeiras fontes da riqueza universal o gravame dos impostos, em maneira tal que sobre todos pese igualmente ${ }^{, 403}$.

Diferentemente do que afirma Valentim Alexandre sobre as propostas de d. Rodrigo de Sousa Coutinho representar apenas um desdobramento das pressões financeiras provocadas pela iminência da guerra com as demais potências europeias ${ }^{404}$, tais propostas, especialmente sobre a extinção do dízimo e a adoção de uma taxação proporcional refletem uma crítica dura ao Antigo Regime, cujas desigualdades fiscais eram provenientes dos privilégios secularmente adquiridos e, portando, serviam também para reafirmar as desigualdades políticas em terras de conquistas.

Além disso, d. Rodrigo criticava as medidas da administração colonial que feriam as fontes de riqueza colonial, oprimindo e desestimulando a agricultura nas capitanias marítimas da Bahia, do Rio de Janeiro e de Pernambuco, como, por exemplo, os malefícios no estanco do sal, sobretudo na criação de gado e na salga das carnes ${ }^{405}$, no contrabando das alfândegas, nos direitos pagos sobre os escravos que entravam no Brasil e nos direitos pagos sobre o aço, o ferro, o cobre o e chumbo. A ideia era que se

\footnotetext{
${ }^{402}$ Apud Bruno Aidar. Uma substituição luminosa, op.cit., p. 144.

${ }^{403}$ Idem. Cf. Rodrigo de Sousa Coutinho. Memória sobre o melhoramento ..., op.cit.

${ }^{404}$ Valentim Alexandre, op.cit., p. 89.

405 Cf. Mirian Ellis. O monopólio do sal no estanco do Brasil (1631-1801). Faculdade de Filosofia, Ciências e Letras da Universidade de São Paulo, 1995.
} 
os direitos de alfândega fossem reduzidos, dinamizar-se-ia o comércio de vinhos, azeite, manufaturados, aço e ferro, tão importantes para Portugal naquela conflituosa conjuntura de final de século. Tais medidas também serviriam para as capitanias mineradoras, Minas Gerais, Goiás, Cuiabá e Mato Grosso, que contaram com medidas específicas como, por exemplo, o quinto do ouro ser diminuído para um décimo, a proibição do curso do ouro em pó, o estabelecimento de casas de permuta e casas de moeda, a fixação de uma taxa anual para cada escravo que passasse para o distrito diamantino e o estabelecimento de um vigésimo de oitava para cada escravo ocupado nas lavras de ouro ${ }^{406}$.

Para Ana Rosa Cloclet parece inegável que a região mineradora ocupou lugar de destaque nas reformas de d. Rodrigo de Sousa Coutinho, pois tanto o ministro quanto os contemporâneos mineiros criam na centralidade da mineração na vida econômica da capitania e pujança da monarquia, preconizando meios distintos para reverterem sua "decadência". Tanto mais que as medidas reformistas de d. Rodrigo de Sousa Coutinho foram elaboradas no sentido de reverter os problemas apontados por d. Rodrigo José de Menezes, no período em que foi governador das Minas Gerais (1780-1783), nomeadamente os problemas do atraso técnico nas Minas e a necessidade de proibição do giro do ouro em pó, com a criação de uma casa da moeda em Vila Rica ${ }^{407}$.

Para a autora, d. Rodrigo de Sousa Coutinho converteu-se no principal projetor e articulador das políticas reformistas dos reinados mariano e joanino. Representando a síntese do "estadista intelectualizado" exigido pela modernização portuguesa, o ministro deu uma implementação regular e sistemática às peregrinações científicas pelo Reino e Ultramar, formulando ainda o mais completo plano de reformas para os domínios da América, no qual ganhava centralidade a província mineira, cujas elites foram chamadas a participarem ativamente da reorientação da política da coroa portuguesa ${ }^{408}$.

Com a capitania das Minas Gerais ocupando lugar de destaque nas formulações reformistas de d. Rodrigo de Sousa Coutinho, suas elites tiveram oportunidade de explicitarem suas demandas locais acerca da melhor forma de aproveitamento do potencial natural da capitania como condição de obediência e unidade, esboçando no final do século XVIII específico contorno ao genérico princípio da reciprocidade de interesses entre as partes do império português. Não obstante a ideologia de

\footnotetext{
${ }^{406}$ Bruno Aidar, op.cit., p. 151.

${ }^{407}$ Ana Rosa Cloclet Silva. Minas no contexto da "acomodação": as relações de poder, as práticas políticas e as tessituras das identidades. Revista Aulas: Dossiê Identidades Nacionais, n. 2, 2006, p. 9.

${ }^{408}$ Idem, p. 14.
} 
reciprocidade de interesses entre a colônia e a metrópole, cumpre destacar que as reformas preservavam os entraves impostos pela condição colonial, o que fica evidente pela restrita permissão para o estabelecimento de manufaturas nos domínios portugueses com a manutenção do Alvará de 1785, devendo a agricultura "ainda por muitos séculos ser-lhe mais proveitosa do que as Artes, que devem animar-se na Metrópole 409 .

Talvez seja por essa razão que, mesmo com a adesão da elite mineira ao projeto reformista de d. Rodrigo de Sousa Coutinho, os contratos do dízimo e das passagens continuaram sendo arrematados e controlados por particulares na Capitania, pois a arrematação em hasta pública por particulares, desde 1760, tornara-se um negócio altamente lucrativo, envolvendo os poderes locais e a autoridades régias sem uma dimensão imperial em suas perspectivas mercantis ${ }^{410}$. Com efeito, Ana Rosa Cloclet demonstra que as reivindicações das elites mineiras tinham limites que eram dados pelo consensual desejo de preservação da ordem e do senso de distinção social que:

"no caso das Minas, adensara-se em virtude das complexas redes de solidariedade entre estas categorias sociais - com destaque para a presença numerosa e ativa desta população livre pobre e liberta, majoritariamente mestiça e negra, em busca de ascensão econômica e social -, engendrando uma sociedade plural, heterogênea e múltipla, no interior da qual as identidades coletivas foram construídas e politizadas "411.

Assim, se por um lado essa negociação das elites mineiras ancorou a possibilidade de superar os obstáculos do Antigo Regime português dentro da ordem, sob a égide do crescimento econômico dos súditos e do Estado, por outro lado, reforçou sentimentos de pertencimento político de tipo particularista, cujo engajamento dessas elites na política reformista de d. Rodrigo de Sousa Coutinho favoreceu suas tomadas de consciência para os propósitos e as medidas políticas relacionadas às suas vidas e à comunidade a que pertenciam $^{412}$. Para a autora, tal situação significa que a crise se manifestaria em outro plano: na distância entre a teoria e a prática dessas políticas econômicas em Portugal e no Brasil.

\footnotetext{
${ }^{409}$ Cf. Memória sobre o Melhoramento dos Domínios de S. Majestade na América, de 1797.

${ }^{410}$ Luiz Antônio Silva Araújo. Política Pombalina e contratos de tributos régios em Minas Gerais. Anais do XXX Encontro da Associação Portuguesa de História Econômica e Social, cujo sítio foi acessado em 22/10/2011: http://www.iseg.utl.pt/aphes30/fullprog.html

${ }^{411}$ Ana Rosa Cloclet Silva, op.cit., p. 26.

412 Idem.
} 
Analisando os intentos das reformas propostas por d. Rodrigo de Sousa Coutinho na capitania de São Paulo, Bruno Aidar nos mostra que corroborou para o fracasso das reformas em relação aos contratadores e ao controle dos gastos a definição de limites na capacidade extrativa e na redução de gastos militares, bem como na disponibilidade de uma estrutura administrativa adequada. As resistências dos contratadores à administração ilustrada adviriam tanto do lado metropolitano, quanto da própria capitania, pois o fracasso em substituir a arrematação pela administração, conforme desejava d. Rodrigo de Sousa Coutinho, ocorreu em razão da influência dos grandes contratadores reinóis sobre o Erário Régio e da incapacidade de obter "bons" contratadores na capitania, homens não endividados e em número suficiente para obter um valor melhor para os contratos arrecadados ${ }^{413}$.

Em relação aos entraves para as reformas sobre o controle dos gastos da capitania de São Paulo, o autor destaca os ordenados irregulares e a debilidade dos recursos para as obras da capitania, pois boa parte era destinada para as guerras do sul. Além disso, os desequilíbrios financeiros persistiam de tal forma que o endividamento com os credores apenas lhes aumentava o poder local, ainda mais porque o vice-rei pouco ajudava nas contas do governo ${ }^{414}$. O autor também nos mostra uma série de atritos com os que dependiam das despesas realizadas pela Junta da Fazenda, conflitos entre os poucos funcionários qualificados da capitania que não desejavam se submeter às novas jornadas de trabalho proposta pelas reformas e muita resistência por parte dos corpos militares e das câmaras municipais, que atrasavam ou extraviavam os dados necessários ao controle das informações contáveis. Em relação à redução dos tributos visando ao fomento agrícola na capitania, apenas na extinção do monopólio do sal pôdese ver alguma medida de maior vulto, pois tampouco os impostos existentes foram substituídos por outros mais brandos ${ }^{415}$.

Com efeito, na capitania de São Paulo, a crise também se manifestou em outro plano, justamente na distância entre a teoria e a prática das políticas econômicas reformistas de d. Rodrigo de Sousa Coutinho em Portugal e na América, pois a contradição entre o fomento da diversificação agrícola e as requisições militares na capitania de São Paulo refletiu, no limite, tanto a incompatibilidade entre os objetivos

\footnotetext{
${ }^{413}$ Bruno Aidar. A tessitura do fisco: a politica ilustrada de D. Rodrigo de Souza Coutinho e a administração fiscal da capitania de São Paulo, 1797-1803. Dissertação de Mestrado/IFCH/UNICAMP, 2007, p. 160.

${ }^{414}$ Idem, p. 161.

${ }^{415}$ Ibidem.
} 
distintos da política ultramarina no final do século XVIII, quanto a necessidade de se analisar a resposta de cada capitania do Brasil para a implantação das reformas de d. Rodrigo de Sousa Coutinho. A repercussão sobre o intento das reformas de d. Rodrigo de Sousa Coutinho também não obteve boa acolhida na Bahia, sobretudo quando se considera a postura do próprio governador da capitania da Bahia e dos homens que faziam parte da corporação dos enteados e eram detentores de privilégios secularmente conquistados.

No final do século XVIII, Salvador compartilhava com a capitania do Rio de Janeiro as diretrizes econômicas que orientavam as relações com outras capitanias e com a metrópole, e continha instâncias político-administrativas responsáveis pela política geral de supervisão de todo território português americano e de partes do continente africano $^{416}$. A manutenção dessa projeção econômica e política da capitania da Bahia no final do século XVIII, que viabilizava a crescente produção para exportação, implicou um conjunto de princípios e normas, muitos dos quais delineados pelas reformas pombalinas, que contemplassem os interesses da coroa portuguesa e dos habitantes da capitania, especialmente os setores ligados à produção para exportação e ao tráfico de escravos.

A documentação demonstra que até 1796, na capitania da Bahia, os interesses metropolitanos e coloniais foram equacionados de tal sorte que tanto os anseios estatais quanto os privados foram contemplados por meio de práticas que fundamentavam o regime mercantilista colonial e o sistema fiscal que lhe era próprio. Por um lado, havia os privilégios e os monopólios, essenciais nos processos de centralização política e expansão ultramarina. Por outro lado, havia o sistema de arrendamentos ou contratação de serviços, funções e comercialização de produtos por particulares, práticas essenciais no processo de arregimentação do setor economicamente privilegiado ao projeto colonial português ${ }^{417}$.

Ao se transformarem em parceiros da Fazenda Real, cuidando privativamente dos interesses da coroa portuguesa, o grupo de contratadores, rendeiros e monopolistas, muitos dos quais ocupando cargos estratégicos na administração pública, sedimentou seu poder e influência na capitania da Bahia, que passou a ser ameaçado com a possibilidade de implantação das reformas de d. Rodrigo de Sousa Coutinho. Do ponto de vista político, cumpre destacar as diferenças entre as reformas propostas por d.

\footnotetext{
${ }^{416}$ Cf. Avanete Pereira de Sousa, op.cit., p. 119.

${ }^{417}$ Idem; István Jancsó, Na Bahia contra o Império, op.cit.
} 
Rodrigo de Sousa Coutinho em seu mais famoso escrito, "Memória sobre o Melhoramento dos Domínios de S. Majestade na América”, de 1797, e as propostas de d. Fernando José de Portugal e Castro, sistematizados nos comentários do regimento de Roque Barreto da Costa, de 1677, que viria a ser o regimento dos Vice-Reis.

Tais diferenças relacionavam-se, sobre tudo, ao benefício que a coroa portuguesa obteria no comércio ilegal com os espanhóis, à maneira como se arremataria os contratos e cargos públicos, à necessidade de se criar uma Caixa de Crédito na Bahia, taxando as operações creditícias dos negociantes, e às implicações com as arrematações dos ofícios de justiça e fazenda para quem desse o maior lance, possibilitando a alternância de grupos no jogo político local que, desde as reformas pombalinas até a última década do século XVIII, era controlado pelo Secretário de Estado e Governo do Brasil e contava com apoio do governador general da capitania, d. Fernando José de Portugal e Castro.

Dos vários itens polêmicos das reformas de d. Rodrigo de Sousa Coutino que contrariava o interesse da corporação dos enteados, sobretudo do Secretário de Estado e Governo do Brasil, José Pires de Carvalho e Albuquerque, o principal deles era o fim dos morgadios, considerado por d. Rodrigo de Sousa Coutinho como um sistema que obstaculizava a distribuição da propriedade e o emprego de novas técnicas agrícolas no universo rural. O sistema de morgadio seria responsável ainda pelo atraso do campo em sua relação com o dinamismo encontrado nas zonas urbanas, cuja propriedade já estava liberta de tradições impeditivas da individualização da propriedade e do livre jogo do mercado $^{418}$.

De acordo com o Livro IV das Ordenações Filipinas, os morgadios se configuraram como uma instituição tipicamente ibérica, existente desde o século XIV até sua revogação em meados do século XIX. Foi abolido na Espanha em 1820 e em Portugal apenas em 1863. Como uma propriedade vinculada, expressaram os esforços de perpetuação da família e manutenção de riqueza, a partir da institucionalização da transmissão do patrimônio via primogenitura ${ }^{419}$. Na prática, seu titular dispunha da renda, mas não dos bens que a produzia, beneficiando-se de todo tipo de usufruto de seu patrimônio, sem poder dispor do valor constituído deste. No entanto, o morgado era um ato de regulamentação administrativo-jurídica de um patrimônio, no qual também se

\footnotetext{
418 Cf. Márcia Maria Mendes Motta. Morgadios e capelas na América Portuguesa do século XVIII. Disponível em: web.letras.up.pt/aphes29/data/4th/MarciaMotta_Texto.pdf. Acessado em 30/08/2012.

${ }^{419}$ Ordenações Filipinas. Livro IV. Lisboa, Fundação Calouste Gulbenkian, s/d, p. 990.
} 
transmitiam modelos de comportamento, regras de conduta social e formas de relacionamento com o mundo dos antepassados, condicionando tanto a posse dos bens como a chefia da linhagem ${ }^{420}$.

Talvez seja por essa razão que, no final do século XVIII, a capitania da Bahia tenha sido o palco de uma disputa pela herança do morgado do Garcia D’Ávila sem precedentes. A contenda foi deflagrada em 1797, quando o Capitão Antônio Ferreira de Andrade escreveu a d. Rodrigo de Souza Coutinho uma carta referente aos péssimos procedimentos de José Pires de Carvalho e Albuquerque na administração da capitania da Bahia e na herança do morgado de Garcia D’Ávila ${ }^{421}$. Segundo Antônio Ferreira de Andrade:

"Fatal Justiça a da Bahia, Exmo. Sr., que obriga a hum Ministro de Estado a ser justa e inevitavelmente importunado à favor da mesma Justiça, aqui toda supplantada, ou subornada por este novo Ditador o referido Secretário! Fatal Justiça a da Bahia, meu Sr., mais venal que a de Roma em tempo de Jugurtha! Esta pequena Relação com effeito, quanto à venalidade, pode bem entrar em parallelo com aquelle magnífico Senado. Apenas o novo Desembargador Antônio Coelho de Azevedo he o único de quem ainda não constão subornos, nem desordens; e das Varas inferiores o Juiz de Fora e do Crime, que por isso não fazem grande figura como venal Juiz dos Orfãos " 422 .

O motivo de tal carta está relacionado a outro José Pires de Carvalho e Albuquerque, Alcaide-mor e o herdeiro natural do morgado dos Garcia d'Ávila, por ser filho de D. Leonor Pereira Marinho. O fato é que o herdeiro morreu solteiro em 28 de julho de 1796, mas tivera tempo de viver em concubinato com Maria da Expectação Alves Braga, com quem teve três filhos, e com Maria dos Anjos, com quem teve outro filho chamado José. Três meses antes de sua morte, entretanto, o Alcaide-mor requereu a legitimação de seus quatro filhos, designando-os como herdeiros legítimos. Para tanto,

\footnotetext{
${ }^{420}$ Márcia Maria Mendes Motta, op.cit., p. 3.

${ }^{421}$ AHU_CU_CA_BAÍA, doc.18245 - Officio do Governador d. Fernando Jose de Portugal para d. Rodrigo de Sousa Coutinho, no qual informa acerca de um requerimento de Antônio Ferreira de Andrade, sobre a herança do margado José Pires de Carvalho e Albuquerque de quem era testamenteiro e tutor de seus filhos naturaes e menores, Bahia, 29 de abril de 1798. AHU_CU_CA_BAÍA, doc. 18247 - Carta particular de Antônio Ferreira de Andrade para D. Rodrigo de Sousa Coutinho, relativa a referida herança de José Pires de Carvalho e Albuquerque. Bahia, 14 de abril de 1797. No final da carta, Antônio Ferreira de Andrade informa sobre as mercês régias que recebera até aquele momento.

${ }^{422}$ AHU_CU_CA_Cx. 93, doc. 18247. Cumpre destacar que Juiz de Fora e do Crime era o desembargador Costa Pinto, e o Juiz dos Órfãos era Francisco Vicente Viana, ambos relacionados às devassas da Conjuração Baiana de 1798.
} 
nomeou seu amigo Antônio Ferreira Andrade testamenteiro e tutor de seus filhos.

Com efeito, o Secretário de Estado junto com seu cunhado Joaquim Inácio de Siqueira Bulcão e a avó de suas respectivas esposas impugnaram o pedido de legitimação dos filhos bastardos do falecido, a validade do testamento e a condição de testamenteiro e tutor das crianças a Antônio Ferreira de Andrade, sob o argumento de que o testamenteiro aproveitara a fragilidade do enfermo e tentara persuadi-lo a estabelecer matrimônio com uma "prostituta de ínfima extração social",423. Para Antônio Ferreira de Andrade, o abuso de autoridade das suplicantes era notório, pois:

"À frente dos taes parentes, andou sempre no maior escândalo o referido Secretário de Estado e Guerra do Brasil, que tem o mesmo nome José Pires de Carvalho $e$ Albuquerque, cujo oficio de Secretário comprado por seu Pai, $e$ o único de semelhante natureza em todos os Governos, (ilegível), além de outro mais de Escrivão da Mesa Grande desta Alfândega, officios ambos de muita dependência nesta Cidade, onde sobre tudo influe o de Secretário até com a posse, ou antes abuso de ter grandes honras Militares além das Civis quasi sem limite; huã tal situação pois o tem constituído nesta Capitania hum pequeno Déspota, que calea aos seus pés tudo quanto se oppoem aos seus interesses, especialmente os da sucessão e herança do referido Morgado" ${ }^{, 424}$.

De fato, antes de falecer, José Pires de Carvalho e Albuquerque pretendeu se casar com Maria da Expectação, porém, em face da oposição da família, ele desistiu do matrimônio:

"achando-se aqui para morrer o Morgado José Pires de Carvalho e Albuquerque, desejou este por desencargo de sua consciência casar com a Mai de huns seus filhos, naturaes, à fim de os deixar legítimos à face da Igreja, e herdeiros sem mais quantão de todos os seus bens, assim vinculados, como allodiaes. Insuregem logo os parentes do dito com as mais evidências contra hum tal casamento, e conseguiram embaraça-lo por toda a sorte de maior: deixando apenas ao enfermo a liberdade de dispor dos bens allodiaes no seu Testamento, em que me nomeou por seu Testamenteiro, e juntamento Tutor dos ditos orfãos seus filhos, que elle solenemente reconheceo à face de toda esta Cidade [...]",425.

\footnotetext{
${ }^{423}$ AHU_ACL_CU_005, Cx. 210, doc. 17264.

${ }^{424}$ AHU_CU_CA_Cx. 93, doc. 18247.

${ }^{425}$ Idem.
} 
Apesar de ter exigido que Ana Maria de São José de Aragão e Joaquina Maurícia de São Miguel e Aragão, bem como seus respectivos esposos, o Secretário de Estado e Governo do Brasil, José Pires de Carvalho e Albuquerque, e o senhor de engenho Joaquim Inácio de Siqueira Bulcão, assinassem em favor de seus filhos naturais um termo de desistência e demissão da herança que estava por deixar ${ }^{426}$, $\operatorname{logo}$ após o falecimento do Alcaide-mor, em 1796, o testamenteiro foi acusado pela avó do defunto, Catarina Francisca Corrêa e Aragão e por sua neta d. Ana Maria de São José e Aragão, esposa do Secretário de Estado, de não só extorquir o testamento, como saquear a "Casa do defunto levando para a sua grande quantia de dinheiro, além do ouro e prata e diamantes que achou [...] e tomar posse de todos os bens de raiz que lhe pareceram ser do defunto e até dos bens do morgado"427.

D. Maria I atendeu a petição das suplicantes, mandando que a Relação da Bahia nomeasse juiz comissário e privativo das causas e pendências das suplicantes - função assumida pelo desembargador José Pedro de Sousa Câmara -, e designasse dois negociantes para administrar a arrecadação das rendas e do sequestro dos bens do falecido José Pires de Carvalho e Albuquerque ${ }^{428}$, entre eles Manoel José Vilella de $\underline{\text { Carvalho, }}$ proprietário de escravos entregues à justiça durante as investigações da Conjuração Baiana de 1798. Antônio José Ferreira afirmou que:

"e os infidáveis direitos, que se achão agora atacados por huã obreptícia e subreptícia Carta Régia, de cujo teor não consta, por qual Secretaria de Estado fosse expedida, nem por que Oficial fosse escrita com a data que tem de 29 de Outubro do próximo anno de 1796, à favor deste prepotente Secretário de Estado e Guerra do Brasil: à quem ex officio de Tutor Testamentário me tinha opposto em defesa de huns inocentes orfãos, que o dito secretário não cessa de sacrificar, como he bem notório em toda esta Cidade ${ }^{, 429}$.

\footnotetext{
426 "Instrumento de desistência e demissão da herança do testador que fazem todos os herdeiros abaixo declarados e aprovação deste testamento como abaixo se declara". Bahia, 21 de junho de 1796. AHU_CU_CA, docs. 24467-24481. Apud Moniz Bandeira, op.cit., nota 42, p. 324.

${ }^{427}$ BN , sessão de manuscritos, II-33, 34, 8 - Representação de D. Catarina Francisca de Aragão e D. Ana Maria de São José de Aragão, avó e irmã de José Pires de Carvalho e Albuquerque, contra Antônio Ferreira de Andrade, acusado de agir de má fé contra os herdeiros e se apropriar dos bens acumulados e livres do dito defunto, cuja confissão foi tomada por um Carmelita Descalço. [...] pedem o sequestro dos bens que a este pertencem, até ser resolvida a validade do testamento que deixara.

${ }^{428}$ AHU_ACL_CU_005, doc. 17264. "Officio do Governador D. Fernando José de Portugal para D. Rodrigo de Sousa Coutinho, em que participa ter nomeado certos desembargadores da Relação juizes privativos das causas em que eram interessados D. Catharina Francisca Corrêa de Aragão e sua neta D. Anna Maria de S. José de Aragão e os herdeiros de José Pires de Carvalho e Albuquerque. Bahia, 6 de abril de 1797'.

${ }^{429}$ AHU_CU_CA_Cx. 93, doc. 18247.
} 
Concorreu decisivamente para o parecer favorável de d. Maria I, uma informação circunstanciada elaborada pelo próprio governador da Bahia, d. Fernando José de Portugal e Castro ${ }^{430}$, corroboradas por "attestações" que demonstram a composição de dois importantes grupos da elite da capitania da Bahia. O Coronel Antônio Ferreira de Andrade, professo na ordem de Cristo, membro de uma "das mais bem abonadas famílias e [dono] de importantes propriedades de engenho de assúcar", contou com as "atestações” fornecidas por José Clarique Lobo, José Teles de Menezes, Sebastião Alves da Fonseca, Manuel de Almeida Maciel, Francisco José de Mattos Ferreira e Lucena, Sebastião da Rocha Soares, José Vieira de Araújo e José da Silva Freire.

Desse grupo, Antônio Almeida Maciel e José da Silva Freire eram prelados de confiança do Arcebispo da Bahia d. Antônio Correa ${ }^{431}$. Sebastião Alves da Fonseca foi Juiz de Fora e Presidente da Câmara de Salvador em $1764^{432}$ e, no ano de 1798, foi um dos que passou certidão sobre o bom desempenho ao Juiz da Vila de Cachoeira, Joaquim de Amorim e Castro, acusado de beneficiar umas das partes em uma disputa de terra $^{433}$. José Vieira de Araújo, por sua vez, Capitão-mor de Benguela, recusou-se em 1798 a vender umas casas de sua propriedade para que Ignácio Ferreira da Câmara pudesse recolher amostras de plantas e enviar para o Real Jardim Botânico ${ }^{434}$. Além disso, Francisco José de Mattos Ferreira e Lucena, por exemplo, Coronel do $2^{\circ}$ Regimento de Infantaria da Bahia, no início de 1798, solicitou como remuneração de seus serviços a propriedade vitalícia de um cargo na administração local e a casa em que

\footnotetext{
${ }^{430}$ AHU_ACL_CU_005, doc. 18245

${ }^{431}$ AHU_CU_CA, Baía, doc. 23757; AHU_CU_CA, Baía, doc. 23500, respectivamente.

432 AHU_CU_CA, Baía, doc. 21120: "Participação do Juiz de Fora e Presidente da Câmara Sebastião Alvares da Fonseca, dirigida a António Alvares de Figueiredo, em que lhe communica que por Alvará do Desembargo do Paço fora nomeado procurador da mesma Câmara durante o próximo anno. Bahia, 27 de dezembro de 1764. (Annexa ao $n^{o}$. 21.112)". Cumpre destacar que, na lista dos vereadores, elaborada por Affonso Ruy, Sebastião Alvares da Fonseca não aparece como vereador da Câmara de Salvador, embora Antônio Alvares de Figueiredo tenha sido, de fato, procurador da Câmara em 1765. Ler, a esse respeito, Affonso Ruy. História da Câmara Municipal da Cidade de Salvador. Salvador: Câmara Municipal, $3^{\text {a }}$. edição, 2002, p. 349.

${ }^{433}$ AHU_CU_CA, Baía, docs. 21792-21806: "Requerimentos de Joaquim de Amorim Castro, Juiz de fora da Villa da Cachoeira, cujo cargo exercera desde 12 de abril de 1787 até 3 de agosto de 1798, no qual pede que se lhe passem certidões de ter sempre cumprido todas as ordens emanadas dos tribunaes e autoridades civis e militares. As certidões estão passadas nos diversos requerimentos".

${ }^{434}$ AHU_CU_CA, Baía, doc. 20.550: “Officio do Governador D. Fernando José de Portugal para D. Rodrigo de Sousa Coutinho, em que se refere ao estabelecimento de um jardim botânico na Bahia, semelhante ao do Pará. Bahia, 17 de maio de 1800”. AHU_CU_CA, Baía, doc. 9499: "Declaração de José Goulart da Silveira, sobre o ordenado, emolumentos e propinas que recebe como official da Vedoria e Contador da gente de guerra do Exército e Presidio. Bahia, 24 de novembro de 1778. (Annexa ao $n$. 9819)".
} 
habitava, que pertencia à Real Fazenda ${ }^{435}$. Para tanto, contou com os pareceres favoráveis do escrivão da Junta da Real Fazenda, Francisco Gomes de Sousa constantemente denunciado por Luís dos Santos Vilhena -, e do próprio d. Fernando José de Portugal e Castro, governador da capitania da Bahia ${ }^{436}$, indicando que o coronel afinou-se politicamente com o grupo do Secretário de Estado no decorrer da disputa pela herança do morgado, sobretudo porque seu irmão, Antônio José de Mattos Ferreira e Lucena, foi um dos que testemunhou contra os réus da Conjuração Baiana de $1798^{437}$.

O grupo comandado por José Pires de Carvalho e Albuquerque que lhe forneceu "atesttações" era composto por Antônio Estanislao Correia, Domingos da Rocha Barros $^{438}$, José Gularte da Silveira ${ }^{439}$, Antônio Cordeiro Villaça, Bernardino de Sena e Araújo, Manoel José Villela de Carvalho, Francisco Vicente Viana, Antônio Barbosa de Oliveira e Caetano Maurício Machado. Desse grupo, quase todos ocuparam cargos da administração local, três deles eram proprietários dos escravos entregues à justiça, um deles foi o advogado de defesa dos réus da Conjuração Baiana de 1798 e dois deles formularam as principais denúncias sobre os quatro réus enforcados 440 .

Percebendo que a coroa nada fazia a respeito das ações de José Pires de Carvalho e Albuquerque, Antônio Ferreira de Andrade resolveu ampliar o circuito administrativo das denúncias, chamando a atenção para o fato de que o Secretário de Estado não só contava com o apadrinhamento político do governador da Bahia como também na corte. De acordo com a denúncia, Francisco Pires de Carvalho e Albuquerque, desembargador na Casa da Suplicação de Lisboa e tio-avô do falecido e, portanto, parente de D. Anna Maria de São José e Aragão, esposa do Secretário de

\footnotetext{
${ }^{435}$ AHU_CU_CA, Baía, doc. 25.954.

436 AHU_CU_CA, Baía, docs. 27.955-27.956: “Atestados do Escrivão da Junta da Real Fazenda Francisco Gomes de Sousa e do Governador D. Fernando José de Portugal, sobre o zelo, préstimo, atividade e serviços do Coronel Francisco José de Mattos Ferreira e Lucena. Bahia, 13 de março de 1798 e 7 de julho de 1800".

${ }^{437}$ Cf. ADCA, pp. 30-60

438 AHU_CU_CA, Baía, doc. 9351: "Declaração de Domingos da Rocha Barros, sobre o ordenado que recebia como Almotacé dos Armazéns Reaes. Bahia, 24 de novembro de 1778. (Annexa ao n. 9819)".

439 AHU_CU_CA, Baía, DOC. 7622: “Certidão passada pelo Escrivão da Junta da administração da Fazenda José Gularte da Silveira, em que declara que nos autos de inventario e sequestro dos bens dos Padres da Companhia de Jesus, nenhuma referencia encontrara aos 13.000 cruzados pedidos pela Mesa da Misericórdia. Bahia, 1 de junho de 1767. Copia: (Annexa ao n. 7620)"; AHU ACL CU 005, Cx. 193, doc. 14104: Bahia, 18 de julho de 1791. CERTIDÃO do $1^{\circ}$ oficial da Vedoria Geral da Bahia, José Gularte de Silveira atestando que João Soares Nogueira assentou praça de soldado voluntário na Companhia do $1^{\circ}$ Regimento de Infantaria Paga da guarnição da Bahia.

${ }^{440}$ CF. Autos de Devassa da Conspiração dos Alfaiates. Salvador: APEB, 2.v, p. 967 et seq.
} 
Estado, favoreceu na corte a representação das suplicantes ${ }^{441}$. Para Antônio Ferreira de Andrade:

"este he hum daquelles casos de prepotência, e de obrepção e
subrepção, que fazem bradar a Terra e o Ceo a favor da
Verdade e da Inocência, tão calumniosamente atacadas em
hum requerimento que maquinou o referido Secretário em
nome de D. Catharina Ferreira Corrêa de Aragão, e mais
parentes, e que também entra elle dito; à fim de transtornar,
como fica transtornada, a mesma Tutela Testamentária, que a
obreptícia Carta Régia fez já passar para a administração de
dois Negociantes contra todas as pias intenções do fallecido
Morgado Testador, e contra todas as saudáveis Leys de S.
Magestade, a quem sacrilegamente forão enganar, e de cujo
Sagrado Nome estão abusando os ditos herdeiros contra os
inocentes menores de baixo dos pretextos mais
escandalosos",442.

Talvez seja em função da presteza no Real Serviço do Secretário de Estado e Governo do Brasil com os empréstimos gratuitos à coroa portuguesa e o auxílio em franquear os documentos aos relevantes serviços para os quais o governador da capitania da Bahia foi designado, que d. Fernando José de Portugal e Castro, contando com a Real aprovação do então príncipe regente, refutou todas as denúncias sobre José Pires de Carvalho e Albuquerque e resolveu definitivamente a disputa da herança a favor das suplicantes, substituindo Antônio Ferreira de Andrade como tutor dos menores por Miguel José Bernardino de Leão - comerciante rico e muito próximo ao Secretário de Estado -, que acabou se casando com a viúva do abonado defunto, Maria da Expectação ${ }^{443}$.

Resolvida a contenda sobre a herança do morgado da Casa da Torre, pouco mais de um ano depois dessa disputa e um mês depois que a revolta foi deflagrada nas ruas de Salvador, em 11 de setembro de 1798, o tabelião público do Judicial e Notas da cidade de Salvador, Antônio Barbosa de Oliveira, um dos homens que testemunhou a favor do Secretário de Estado e Governo do Brasil, passou a escritura contendo a

\footnotetext{
${ }^{441}$ APEB, Ordens Régias, vol. 85, doc. 41.

${ }^{442}$ AHU_CU_CA_Cx.93, doc. 18247.

${ }^{443}$ AHU_ACL_CU_005, doc. 17264. "Officio do Governador D. Fernando José de Portugal para D. Rodrigo de Sousa Coutinho, em que participa ter nomeado certos desembargadores da Relação juizes privativos das causas em que eram interessados D. Catharina Francisca Corrêa de Aragão e sua neta D. Anna Maria de S. José de Aragão e os herdeiros de José Pires de Carvalho e Albuquerque. Bahia, 6 de abril de 1797".
} 
criação e instituição do morgado de José Pires de Carvalho e Albuquerque ${ }^{444}$. Apesar das duras críticas que d. Rodrigo fizera sobre a instituição dos morgadios e as denúncias contra o Secretário de Estado à frente do principal cargo da administração pública, José Pires de Carvalho de Albuquerque contou com o apoio do governador da capitania da Bahia, de outros proprietários de escravos entregues à justiça durante as investigações da Conjuração Baiana de 1798 e da própria coroa portuguesa.

A instituição do morgado de José Pires de Carvalho e Albuquerque significava naquele final do século XVIII, conforme demonstra Vera Ferlini, a reiteração do latifúndio como forma específica e adequada às determinações mercantis da colonização, bem como a exclusão da população livre da posse da terra, a permanência de uma política de controle do poder local que, no limite, sedimentava arraigada estrutura de privilégios veementemente combatidos pelas propostas de reforma de $\mathrm{d}$. Rodrigo de Sousa Coutinho ${ }^{445}$.

Naqueles anos finais do século XVIII, além do poder político do Secretário de Estado junto ao governador da capitania da Bahia, franqueando-lhe a documentação relativa à memória do Estado, e junto à coroa portuguesa com sucessivos empréstimos gratuitos, José Pires de Carvalho e Albuquerque passou a ser o proprietário do principal morgado do Brasil por matrimônio com a herdeira, d. Anna Maria de São José de Aragão, composto por 348 propriedades, entre fazendas, sítios e terrenos, muitos dos quais situados ao norte da capitania e arrendados ${ }^{446}$.

Entre os arrendatários estava Bernardino de Senna e Araújo, denunciado por venalidade como Escrivão do Juiz dos Órfãos e proprietário de um dos escravos entregues à justiça durante as investigações da Conjuração Baiana de 1798, e Joaquim José de Sant'Anna, um dos principais denunciantes da reunião abortada, marcada para a noite de 25 de agosto, no Dique do Desterro, para os partícipes darem início ao levante $\operatorname{armado}^{447}$. De acordo com o Tombo dos bens patrimoniais da Casa da Torre, realizado em 21 de outubro de 1815, pelo primogênito do Secretário de Estado, Antônio Joaquim Pires de Carvalho e Albuquerque, Joaquim José de Sant'Anna arrendou o sítio Catinga,

\footnotetext{
444 AHU_ACL_CU_005, Cx. 211, D. 14893. “CERTIDÃO do tabelião público do Judicial e Notas da cidade de Salvador, Antônio Barbosa de Oliveira, contendo o teor da escritura, criação e instituição do morgado de José Pires de Carvalho e Albuquerque".

445 Cf. Vera Lucia de Amaral Ferlini. Terra, Trabalho e Poder: O Mundo dos Engenhos no Nordeste Colonial. São Paulo, Brasilense, 1988.

${ }^{446}$ Luiz Alberto Moniz Bandeira. O Feudo. A Casa da Torre de Garcia d'Ávila: da conquista dos sertões à Independência do Brasil. Rio de Janeiro, Civilização Brasileira, 2000, p. 416.

${ }^{447}$ Idem.
} 
por dois mil e quinhentos réis por ano, e o sítio Jabuticaba, ambos situados na região de Jeremoabo, ao norte da capitania da Bahia ${ }^{448}$.

Até o momento, não foi possível encontrar a data dos contratos dos arrendamentos entre o Secretário de Estado e um dos principais denunciantes da Conjuração Baiana de 1798, mas tudo leva a crer que essa operação tenha sido realizada no curso ou depois das investigações do movimento, pois no momento da denúncia, nos autos das devassas, não consta a informação de que Joaquim José de Sant'Anna fosse arrendatário de terras no norte da capitania ${ }^{449}$. Considerando as atitudes do Secretário de Estado, denunciadas por Antônio José Ferreira, não parece exagerada a afirmação de que muito provavelmente José Pires de Carvalho e Albuquerque tenha feito algum tipo de acordo no qual Joaquim José de Sant'Anna denunciaria a reunião no Dique do Desterro, dando início as prisões e investigações, em troca dos arrendamentos de duas propriedades do Secretário de Estado.

Seja como for, a contenda sobre a herança do morgado da Casa da Torre não foi a única que ocorreu na capitania da Bahia, pois como se teve oportunidade de demonstrar no capítulo anterior, naquele final de século agravaram-se os conflitos de jurisdição entre os governadores e as Juntas de Fazenda, especialmente depois do Decreto de 16 de fevereiro de 1799, que ampliava os poderes das Juntas ${ }^{450}$. Entre as novas atribuições, por Provisão de 22 de abril de 1799 e Decreto de 20 de outubro de 1798, o Presidente do Real Erário determinou o que d. Rodrigo de Sousa Coutinho já tinha anunciado no final de 1796: as Juntas da Fazenda dos domínios ultramarinos e ilhas ficaram responsáveis pelas nomeações de todos os ofícios de Fazenda e Justiça de suas respectivas repartições, restando aos governadores apenas a assinatura dos provimentos dos cargos, como presidente destas ${ }^{451}$.

\footnotetext{
${ }^{448}$ Tombo dos bens patrimoniaes da Casa da Torre, levantada em 21 de outubro de 1815, por Antônio Joaquim de Carvalho e Albuquerque Cavalcanti de Avila Pereira. Annaes do Archivo Público e Museu do Estado da Bahia, volume XI, Bahia, 1923, pp. 81 a 87. A relação completa com as propriedades do morgado da Torre de Garcia d'Ávila pode ser encontrada em: Ângelo Emílio da Silva Pessoa. As ruínas da tradição: a Casa da Torre de Garcia d'Ávila. Família e Propriedade no Nordeste Colonial. São Paulo: DH/FFLCH/USP, Tese de Doutorado, 2003; Moniz Bandeira, op.cit, p. 416; Márcia Motta, op.cit., 16-18; Pedro Calmon. História da Casa da Torre: uma dinastia de Pioneiros. Rio de Janeiro: José Olympio, 1939.

${ }^{449}$ AHU_CU_CA, Baía, doc. 19223: "Officio do Arcebispo D. Fr. António Corrêa para D. Rodrigo de Sousa Coutinho, em que se refere ás devassas a que se procedera contra vários indivíduos accusados de publicarem folhetos sediciosos e tramarem uma conspiração, ao seu julgamento e ás recompensas que se deveriam conceder aos denunciantes Joaquim José da Veiga e Joaquim José de Sant'Anna". Grifo meu.

${ }^{450}$ Cf. Fernando José de Portugal e Castro. Comentários ao Regimento de Roque da Costa Barreto. In: Marcos Carneiro de Mendonça. Raízes da Formação administrativa do Brasil. Rio de Janeiro: IHGB/CFC, 1972, vol. 2, pp. 756-757.

${ }^{451}$ AHU_CU_CA, Baía, docs. 26073-26074.
} 
Além disso, o Presidente do Real Erário mandou suspender o pagamento das propinas que se cobravam nas arrematações dos contratos e rendas reais na Secretária de Estado, sob o comando de José Pires de Carvalho e Albuquerque ${ }^{452}$, que sofreria grandes prejuízos com a perda de tais rendimentos. Tal situação desagradou profundamente o governador da Bahia e o Secretário de Estado e Governo do Brasil, José Pires de Carvalho e Albuquerque, que apesar de sua família ter pagado duas vezes pela vitaliciedade do cargo de Secretário de Estado, corria o risco de perdê-lo para qualquer outra pessoa que o arrematasse por maior valor.

D. Fernando rapidamente tratou de expor os inconvenientes das novas medidas a d. Rodrigo de Sousa Coutinho, argumentando que a "experiência" mostrava que às vezes se arrematavam "as serventias dos Ofícios que em despique, e por ódio a outros ofereciam donativo mais vantajoso", redundando em prejuízo público, "ficando preteridos os serventuários mais beneméritos", que não confundiriam cartórios e arquivos, e nem desencaminhariam Cartas, Autos, Petições e outros papéis com a mudança trienal de lugar em que ficavam os mesmos cartórios ${ }^{453}$.

Tudo leva a crer que o que estava subjacente ao argumento de "serventuários beneméritos" é a permanência de José Pires de Carvalho e Albuquerque à frente da Secretaria de Estado, cuja família obtivera por décadas o controle exclusivo da memória cartorial do Estado, pagando duas vezes pela vitaliciedade e hereditariedade do cargo. Além disso, o parecer final de d. Fernando José de Portugal e Castro acerca das arrematações dos ofícios é revelador:

"no novo Regimento se determine que o Vice-Rei possa prover as serventias dos Ofícios de Justiça que estiverem vagos, ou vagarem, por Provisões anuais expedidas no Real Nome, que deverão passar pela Chancelaria, pagando-os os novos direitos e satisfazendo os serventuários as terças partes, nas formas das ordens já citadas, segundo a sua avaliação, mas sem Donativo, vindo assim a receber a Real Fazenda o mesmo que recebem os proprietários dos seus serventuários, na forma da lei [...] como se está praticando na Bahia [...] como determina a Carta Régia de 3 de abril de 1709 e as Provisões de 3 de fevereiro e de 30 de agosto de 1719, dirigidas ao Conde Vimeiro, cuja observância se recomendou vivamente pela [Carta Régia] de 24 de novembro de 1725 ..."454.

\footnotetext{
452 AHU_CU_CA, Baía, docs. 26073-26079.

${ }^{453}$ Idem, p. 757 .

${ }^{454}$ Ibidem. Grifo meu.
} 
Além de o argumento fortalecer o poder do Vice-Reinado, cargo que ele passaria a ocupar a partir de 1801, novamente d. Fernando José de Portugal e Castro valeu-se do conhecimento acerca da memória do Estado franqueado pelo Secretário de Estado para resolver mais uma questão administrativa de interesse para ambos, valendo-se do capítulo 40 do Regimento dos Governadores e Capitães Generais da capitania da Bahia $^{455}$ que eram os responsáveis pelo provimento de novos cargos, aumento do soldo e reformas militares ${ }^{456}$. José Pires de Carvalho e Albuquerque não tardou em apresentar seus protestos à coroa portuguesa, valendo-se da cópia dos parágrafos oito e nove do Regimento de seu cargo, e aproveitou para sugerir que caso perdesse o direito das propinas arrecadadas em razão dos provimentos dos ofícios de fazenda e justiça, ele suspenderia os empréstimos gratuitos constantemente feitos à Real Fazenda para a construção de naus e pagamentos de despesas extraordinárias da capitania da Bahia ${ }^{457}$.

Em razão da possibilidade de perder o importante cargo de Secretário de Estado e Governo do Brasil, José Pires de Carvalho e Albuquerque foi submetido a uma devassa de residência para apurar seu comportamento na Secretaria de Estado, procedida pelo chanceler da Relação da Bahia, Firmino de Magalhães Siqueira da Fonseca, em 1 de agosto de 1798, portanto onze dias antes de a Conjuração Baiana de 1798 ser deflagrada nas ruas de Salvador ${ }^{458}$. José Pires de Carvalho e Albuquerque contou com o apoio de pessoas importantes da capitania da Bahia para suas reivindicações, apresentando "attestações" assinadas pelos vereadores da Câmara; pelo escrivão da administração da Real Fazenda - Francisco Gomes de Sousa -; pelo escrivão do Almoxarife e oficiais dos Armazéns Reais; pelo Arcebispo da Bahia; pelos governadores da capitania da Bahia que antecederam e sucederam d. Fernando José de Portugal e Castro; e pelos governadores interinos, entre eles o próprio chanceler da Relação da Bahia, responsável por sua devassa de residência ${ }^{459}$.

\footnotetext{
455 AHU_CU_CA, Baía, doc. 12.830.

${ }^{456}$ ArnoWehling, op.cit, ler, especialmente, o capítulo III, “Esferas Administrativas”, pp. 45-60.

457 AHU_CU_CA, Baía, doc. 26066, com certidão anexa. "Cópia dos Parágraphos oito e novo do Regimento do Offício de Secretário de Estado e Governo do Brasil, de 28 de julho de 1669". AHU_CU_CA, Baía, doc. 26171. "Certidão da quantia com que o Secretário de Estado José Pires de Carvalho e Albuquerque entrou nos cofres da Real Fazenda para o empréstimo que se mandara abrir na Capitania da Bahia, em 8 de novembro de 1797".

${ }^{458}$ AHU_CU_CA, Baía, doc. 26163. “Auto de Inquirição de testemunhas a que procedeu o Chanceller da Relação da Bahia sobre a identidade e serviços do Secretário de Estado e Guerra do Brasil. Bahia, 1 de agosto de 1798".

${ }^{459}$ AHU_CU_CA, Baía, docs. 26095-26100. “Attestados (6) do Escrivão da Junta da Administração da Real Fazenda, do Escrivão do Almoxarife e Officiaes dos Armazens Real, do Escrivão da Vedoria e dos Officiaes da Alfândega sobre os serviços de José Pires de Carvalho e Albuquerque nos desempenhos dos cargos de Intendente da Marinha e Provedor da Alfândega”. AHU_CU_CA, Baía, doc. AHU_CU_CA,
} 
O resultado da devassa de residência do Secretário de Estado e Governo do Brasil não foi importante, pois muito provavelmente em razão dos empréstimos gratuitos para a Real Fazenda, da importância política de José Pires de Carvalho e Albuquerque e da revolta deflagrada nas ruas de Salvador em 1798, a coroa portuguesa resolveu definitivamente essa questão a favor do Secretário de Estado e Governo do Brasil quando d. Fernando José de Portugal e Castro estava à testa do Vice-Reinado. Com efeito, em 1804, José Pires de Carvalho e Albuquerque solicitou a entrega das propinas que lhe pertenciam e se achavam em depósito ${ }^{460}$ durante o período em que foram suspensas de serem recolhidas na Secretaria de Estado ${ }^{461}$, contando com o apoio decisivo do governador da capitania da Bahia que sucedeu d. Fernando José de Portugal e Castro, Francisco da Cunha Menezes ${ }^{462}$.

Situação semelhante aconteceu em relação à arrematação dos dízimos. De acordo com d. Rodrigo de Sousa Coutinho, o fim da arrematação em hasta pública deveria ocorrer porque:

"as Despesas que exigia hum estado respeitável de Defesa, a Organização do Credito Publico por meio de hum Estabelecimento onde se pagam religiosamente os Juros das Dividas do Estado; a criação de Impostos moderados que ou recaem sobre a gente abonada que melhor os pôde pagar, quais a decima dos Dízimos, o Quinto dos Bens da Coroa, ou sobre todos em geral e moderadamente quais os Impostos do Papel Selado; são certamente Operações de Fazenda as mais louváveis, e que unidas ao Empréstimo que se abriu fazem ver que em tal e tão importante matéria abraçou o nosso Grande Príncipe tudo que se acha mais sancionado pela experiência das outras Nações ",463.

Baía, docs. 26103-26107. "Attestados (5) dos Vereadores da Câmara da Bahia, do Arcebispo D. Fr. Antônio de Correa, dos Governadores Marquez de Valença e D. Rodrigo José de Menezes e dos Governadores Interinos da Capitania da Bahia, sobre os serviços, zêlo e comportamento de José Pires de Carvalho e Albuquerque".

${ }^{460}$ AHU_CU_CA, Baía, doc. 26076.

461 AHU_CU_CA, Baía, doc. 26079: "Provisão expedida pelo Presidente do Real Erário, pela qual se mandou suspender o pagamento das propinas que se cobravam nas arrematações dos contratos e rendas reaes". Cumpre destacar que a referida Provisão data de 21 de maio de 1795, mas de acordo com o Decreto de 20 de outubro de 1798 e a Provisão de 22 de abril de 1799, tal medida passou a vigorar depois que d. Rodrigo de Sousa Coutinho assumiu a Secretaria de Estado e Domínios Ultramarinos.

462 AHU_CU_CA, Baía, doc. 26066. "Offício do Governador Francisco da Cunha Menezes para o Visconde de Anadia sobre os serviços prestados pelo Secretário de Estado e Guerra do Brasil José Pires de Carvalho e Albuquerque. Bahia, 10 de julho de 1804".

463 Marquês do Funchal, Discurso I feito pelo Illmo e Exmo Sr. D. Rodrigo de Sousa Coutinho, na abertura da Sociedade Real Marítima, em 22 de Dezembro de 1798. In: O Conde de Linhares, Dom Rodrigo Domingos António de Sousa Coutinho, Lisboa, 1908, pp. 105-115. 
O discurso de d. Rodrigo de Sousa Coutinho na abertura da Sociedade Real Marítima, no início de 1798, reflete a importância que ele atribuía às taxações para a dinamização da defesa militar e dinamização da marinha portuguesa, especialmente a arrecadação dos dízimos naquele conflituoso final de século. É consenso entre a historiografia que, embora a cobrança dos dízimos recaísse sobre uma série de produtos - entre eles o tabaco, arrematado na capitania da Bahia pelo Secretário de Estado José Pires de Carvalho e Albuquerque - ${ }^{464}$, a partir do século XVII a taxação passou a ser vinculada predominantemente ao açúcar, sobretudo no final do século XVIII quando as exportações atingiram níveis altíssimos e a arrematação dos dízimos foi impulsionada pelos contratadores com o programa reformista de diversificação da produção ${ }^{465}$.

Embora a produção de açúcar para exportação tivesse alcançado índices elevados naquele final de século, a insistência de d. Rodrigo de Sousa Coutinho na alteração da arrematação dos dízimos para aumentar a receita da Real Fazenda parece relacionar-se, para o caso da capitania da Bahia, à diminuição dos empréstimos feitos pelos negociantes entre os anos de 1797 e 1798, que caiu de 189:757\$653 para 97:779 \$294, conforme demonstra Carlos Gabriel Guimarães ao analisar os rendimentos das capitanias de Minas Gerais, Bahia, Pernambuco e Rio de Janeiro ${ }^{466}$. Muito provavelmente a queda dos empréstimos feitos pelos negociantes da capitania da Bahia ocorreu em razão da tentativa de implantação de uma Caixa de Crédito por d. Rodrigo de Sousa Coutinho, que passaria a taxar as transações creditícias.

Seja como for, d. Rodrigo de Sousa Coutinho ganhou adeptos ao seu projeto modernizador na capitania da Bahia, entre eles, o Provedor da Casa da Moeda em Salvador e, depois de 1799, Provedor da Alfândega. Em 27 de outubro de 1797, José Venâncio de Seixas escreveu um plano para d. Rodrigo de Sousa Coutinho, com o

\footnotetext{
${ }^{464}$ AHU_CU_CA_Baía, Cx. 66, doc. 12703 e doc. 12704. Fernando Dores Costa esclarece a importância do contrato do tabaco no final do século XVIII, pois "o contrato do tabaco tem uma importância política que transcende o seu peso relativo nas receitas régias: provém, por um lado, das entradas mensais das prestações contratuais, cuja regularidade leva a que funcione como caixa da Coroa, por outro, do facto de cobrir com a sua rede todo o território, pelo que é frequentemente utilizado como uma efetiva rede de «ocupação» desse território. Basta para tal verificar o papel do contrato nos pagamentos militares". Ler: Fernando Dores Costa. Capitalistas e serviços: empréstimos, contratos e mercês no final do século XVIII. Análise Social, vol. XXVII (116-117), 1992 (2. $\left..^{\circ} 3 .^{\circ}\right), 441-460$.

${ }^{465}$ Cf. Avanete Pereira de Sousa, op.cit., pp. 122-130; Bruno Aidar. A tessitura do fisco, op.cit., pp. 124130; Frédéric Mauro. O papel econômico do fiscalismo no Brasil colonial (1500-1800). In: MAURO, Frédéric. Nova História e novo mundo. São Paulo: Perspectiva/Edusp, 1969, pp. 197-198.

${ }^{466}$ Carlos Gabriel Guimarães. O rendimento da Capitania das Minas Gerais no período 1795-1800: uma comparação com as Capitanias do Rio de Janeiro, Bahia e Pernambuco. Disponível no sítio: http://www.cedeplar.ufmg.br/diamantina2004/textos/D04A032.PDF. Acessado em: 24/09/2011. APEB, Colonial, Fundo Governo Geral/Governo da Capitania. Registro de Correspondência expedida para o Rei, Maço 183, folhas 300, 300 v, 301, 301v.
} 
objetivo de "aumentar as rendas reaes da Capitania da Bahia", afirmando a importância de empréstimos naquela conflituosa conjuntura de final de século e a necessidade do fim de certos monopólios, o aumento de alguns impostos e o maior controle do Estado sob a produção para exportação - contrariando o grupo de notáveis ligados aos setores produtivos da capitania, por serem detentores de certos monopólios.

Para José Venâncio de Seixas, a Capitania da Bahia era uma das mais florescentes e dignas da atenção de d. Rodrigo de Sousa Coutinho, Ministro da Marinha e Domínio Ultramarinos, pela sua posição estratégica, pelas suas produções e pelo seu comércio, que até 1796 conservou na administração da Real Fazenda tal equilíbrio que, não obstante as despesas extraordinárias com as grandes remessas de madeiras para o Arsenal da Marinha de Lisboa e a construção de quatro fragatas, em um espaço de oito anos, a capitania da Bahia:

"se não vio obrigada como a do Rio de Janeiro a contrahir dívidas que a oprimissem, fazendo não só face à todas as sobreditas despesas, passando ordinariamente no fim de cada hum ano para o seguinte a cargo do Thesoureiro Geral hum saldo de setenta conto de reis de rendimentos geraes" $" 467$.

No entanto, segundo o provedor, a situação mudou em 1796, desde que principiaram as construções das fragatas, expedindo-se ordem pelo Real Erário à Junta da Fazenda para que se abrisse um empréstimo às novas despesas e consignações para Lisboa, fazendo com que a Real Fazenda da Bahia contraísse dívidas que antes não tinha. Após lamentar as consequências financeiras aos cofres da capitania da Bahia pelas construções das fragatas e pelos custeios das viagens, José de Venâncio de Seixas afirma que:

"teria contudo posto a Junta da Fazenda no maior aperto, e talvez na triste situação de não poder cumprir as ordens de $S$. Magestade se o Seu Vigilantíssimo Ministério [d. Rodrigo de Sousa Coutinho] não tivesse ao mesmo tempo providenciado a entrada de Cabedaes nos Cofres Régios por meio do Empréstimo que authorizou, do qual result[ou] alguns fundos, [que] se forão entregando à medida que entravão ao dito General, que por este meio pôde suprir todas as despesas que lhe erão necessárias para continuar huma viagem "468.

O Provedor da Casa da Moeda constatou o aumento das despesas reais e propôs um plano de novos impostos para que os rendimentos pudessem suprir as novas

\footnotetext{
${ }^{467}$ AHU_CU_CA, Baía, Cx. 90, doc. 17481.

${ }^{468}$ Idem.
} 
despesas, evitando que a capitania da Bahia ficasse como a do Rio de Janeiro que, em 1783, era devedora de mais de seis milhões de $\operatorname{cruzados}^{469}$. O plano consistia em alguns pontos cruciais. O primeiro deles impunha um tostão em cada arroba de tabaco, três vinténs em cada arroba de algodão, meio de sola, Baqueta e Couro. A ideia era cobrar menos impostos em mais gêneros, porque como a maior parte desses produtos saia do Reino para ser comercializada nos mercados estrangeiros, para José Venâncio de Seixas seria "contra todas as regras da Economia política impor neles Direitos que [pudessem] empatar e talvez impossibilitar a sua venda".

O segundo ponto consistia em que o contrato dos dízimos reais da capitania da Bahia não fosse mais arrematado em leilão, mas sim administrado pela Junta da Real Fazenda, dando uma nova forma à cobrança do dízimo do açúcar. Para José Venâncio de Seixas, a ideia era transferir o enorme lucro dos arrematadores para os cofres públicos, nas mãos de homens sumamente hábeis e não mais proprietários de cargos, para que assim a Real Fazenda pudesse obrar em benefício público. O terceiro ponto do plano de José Venâncio de Seixas, não menos controverso, referia-se ao pagamento de parte das dízimas das fazendas fabricadas no reino na Real Fazenda da Bahia. De acordo com o Provedor da Casa da Moeda, o aumento do rendimento da Alfândega da Bahia não ocorreria pela mudança nominal do dízimo, mas pela mudança proporcional do valor das mercadorias, as quais ele cria estarem muito mal avaliadas, pois a pauta da Alfândega havia sido feita 80 anos antes, quando as minas do Brasil começavam a fornecer ouro e os preços das mercadorias eram outros ${ }^{470}$.

O fato é que, na capitania da Bahia, o negociante português Antônio José Ferreira aparece como o principal contratador dos dízimos na última década do século XVIII, cujos contratos foram arrematados sucessivamente em sociedade com Jacinto Fernandes Bandeira e Joaquim Pedro Quintela. Os negociantes portugueses ascenderam socialmente com uma cota modesta no estanco do sal e da pesca da baleia para tornarem-se também sócios nos contratos dos dízimos de Pernambuco e de São Paulo, além de possuírem uma companhia para exploração de manufaturas régias de lanifícios em Covilhã, Fundão e Portalegre ${ }^{471}$.

\footnotetext{
469 Ibidem.

${ }^{470}$ AHU_CU_Cx 90, doc. 17481.

${ }^{471}$ Cf. Jorge Miguel Pedreira. Tratos e contratos: actividades, interesses e orientações dos investimentos dos negociantes da praça de Lisboa (1755-1822. Análise Social,, vol. XXXI (136-137), 1996 (2. $\left.{ }^{\circ}-3 .^{\circ}\right)$, 355-379; Bruno Aidar. A tessitura do fisco, op. cit., 125-131.
} 
Justamente porque d. Rodrigo de Sousa Coutinho prescrevia que a arrematação dos contratos deveria ser feita nas Juntas de Fazenda e em benefício à Real Fazenda, ele também era terminantemente contra a prorrogação das arrematações por decreto, como acontecia com os contratos arrematados por Antônio José Ferreira e seus sócios, pois tal prática, porque comum na última década do século XVIII, significava a patrimonialização crescente dessas rendas $^{472}$. Cumpre destacar que o principal mecanismo para a patrimonialização dos contratos arrematados foram os empréstimos gratuitos feitos à coroa portuguesa. Assim como o Secretário de Estado e Governo do Brasil, José Pires de Carvalho e Albuquerque, emprestou quantias consideráveis à coroa portuguesa na última década do século XVIII em troca de muitos benefícios e privilégios, o grupo de Antônio José Ferreira também o fez, sendo que no ano de 1794 os contratadores emprestaram à coroa $800.000 \$ 000$ rs obtendo como contrapartida a prorrogação de um dos seus contratos por mais seis anos, de 1797 a $1802^{473}$.

Fernando Dores Costa demonstra que, depois de algumas denúncias, em 1800, a Junta Provisional ${ }^{474}$ promoveu a anulação de dois contratos que estavam na posse de Antônio José Ferreira há mais de dez anos e que haviam sido prorrogados em bloco para o período de 1800-1805, em 20 de março de 1795, em cumprimento ao decreto de 20 de dezembro de 1794 - cinco anos antes de entrarem vigor. De acordo com o autor, a Junta Provisional entendeu que as prorrogações dos contratos "vexavam" a Real Fazenda de S. M. em relação "a disporpoção do preço do Contracto Prorrogado com o valor que já lhe dão os novos lançadores e o maior valor ainda que lhe dão as notícias particulares $" 475$, impedindo, portanto, a concorrência de outros negociantes nas

\footnotetext{
${ }^{472}$ Cf. Fernando Dores Costa. Capitalistas e serviços: empréstimos, contratos e mercês no final do século XVIII. Análise Social, vol. XXVII (116-117), $1992\left(2 .^{\circ}-3 .^{\circ}\right)$, p. 448.

${ }^{473}$ Idem, p. 450. Defendendo a tese de que as prorrogações dos contratos eram mercês e, como tais, tratadas por remunerações de serviços para a coroa portuguesa, Fernando Dores Costa afirma: "esta fórmula da 'aceitação' é, ela própria, significativa: um empréstimo como este é um 'oferecimento' feito pelos capitalistas à Coroa, e esta, no decreto, manifesta a 'aceitação' de tal 'oferecimento' como um serviço a ela prestado. O empréstimo é uma operação que se representa como se se fizesse no sentido inverso àquele em que realmente se faz, como iniciativa dos capitalistas, e não do governo régio. Fórmula aparentemente vazia, ela codifica, de facto, a valorização da operação como serviço, pela sua aceitação".

${ }^{474}$ Segundo Joaquim Caetano Pereira e Sousa, advogado da Casa da Suplicação, autor de "Esboço de Hum Diccionário Jurídico, Theórico e Practico, Remissivos às Leis Compiladas e Extravagantes", Tomo Segundo, Obra Póstuma, publicada em 1827 pela Typographia Rollandiana, a Junta Provisional do Real Erário foi criada no final do ano de 1799 para elaborar propostas destinadas a combater a situação de catástrofe financeira. Foi chamada a pronunciar-se sobre as mais variadas questões do domínio financeiro, tendo sido dissolvida logo após a morte do citado marquês e a chegada de Sousa Coutinho à Secretaria da Fazenda.

${ }^{475}$ Fernando Dores Costa, op.cit., p. 452.
} 
arrematações, uma vez que o edital público para a arrematação em hasta pública era substituído por decretos.

Essa situação também ocorreu nesse lado do Atlântico no final do século XVIII, envolvendo novamente Antônio José Ferreira e seus sócios, que solicitaram no início de 1796 a prorrogação dos contratos dos dízimos de Pernambuco e da Bahia por um período de mais seis anos, sob alegação de ter feito subir os preços dos dois contratos em $173.536 \$ 000$ rs., e ter empatado mais de $600.000 \$ 000$ rs em razão das perdas que sofrera das embarcações tomadas pelos franceses. Ocorre que se o contrato de Pernambuco estava para terminar no final daquele ano, o contrato do dízimo da Bahia só terminaria três anos depois, no final de 1799, de maneira que, caso a prorrogação fosse consentida novamente por decreto real, o contrato do dízimo não seria aberto por edital para ser arrematado em hasta pública, conforme previam os Regimentos da Fazenda.

Com efeito, tal medida interferiria diretamente nos negócios do grupo do Secretário de Estado, especialmente para Francisco Vicente Viana que, depois de concluir seus estudos em Coimbra, em 1773, já de volta a Bahia, foi Juiz de Órfãos, em 1775 - momento em que o juizado aparece como a segunda maior instituição credora da Capitania -, e, em 1779, foi Ouvidor da Comarca da Bahia, função que exerceu enquanto cuidava dos negócios herdados de seu pai, Fructuoso Vicente Viana: tráfico de escravos e arrematação dos dízimos reais, junto com outros negociantes e traficantes como Inocêncio José da Costa e Manoel José Vilella de Carvalho, responsável também pela coleta do subsídio literário ${ }^{476}$. Tudo leva a crer que esse grupo foi substituído pelo grupo de negociantes portugueses, entre eles Antônio José Ferreira, e que naquele final de século esperava pela arrematação do contrato do dízimo novamente em sociedade com outros negociantes soteropolitanos.

Seja como for, o comerciante português justificou o pedido de prorrogação, alegando a seu favor as chuvas em Pernambuco e na Bahia que atrapalharam a produção, sempre pagara em dia as prestações dos contratos arrematados e que naqueles tempos difíceis de conflito entre as nações europeias sofrera graves prejuízos com algumas das suas embarcações tomadas pelos franceses. Fernando Dores Costa

\footnotetext{
${ }^{476}$ Para uma visão geral da família de Francisco Vicente Viana, ler: Bulcão Sobrinho, Antônio de Araújo de Aragão. Famílias Bahianas - Bulcão, Pires de Carvalho e Vicente Viana, Imp. Oficial, Salvador, 1945, 134-70 p. Sobre a nomeação de Francisco Vicente Viana para Ouvidor da Comarca da Bahia, cf: Arquivo Histórico Theodoro Sampaio, Arquivo do Instituto Geográfico e Histórico da Bahia, Arquivo Pessoal de Francisco Vicente Viana, Caixa 01. Sobre Francisco Vicente Viana pertencer ao grupo de arrematadores dos dízimos reais, cf. AHU_CU_CA, baía, docs. 12857, 13284.
} 
demonstra, no entanto, que o principal argumento do comerciante português residiu no fato de que ele emprestava sucessivamente à coroa portuguesa o valor das prestações contratuais, devendo ser, por isso, remunerado com a possibilidade de recuperar os prejuízos alegados $^{477}$.

O parecer da Junta Provisional declarou que:

"a prorrogação que pede he materia de graça, por que o tempo regulado para as arrematações dos Contractos he de trez annos e não de seis; por que havendo prorogação não chegão os Contractos à Praça como determinão os Regimentos da Fazenda e porque arrematando-se pelos mesmos preços, fica desvanecida a vantagem que pode rezultar da concorrencia dos Lançadores ",478.

Não obstante ao argumento professado por d. Rodrigo de Sousa Coutinho sobre a prorrogação dos contratos acarretar graves prejuízos à Real Fazenda, a mesma Junta Provisional baseada no fato de que "o perigo que ha em arrematar estes Contractos com rapidez sem huma verdadeira Informação que he dificultoza ao perto, por que os lucros se escondem, quanto mais ao longe", despachou parecer favorável a prorrogação do contrato do dízimo de Pernambuco para Antônio José Ferreira e seus sócios em 20 de abril de 1797 e, depois de darem 180.000\$000 como donativo à Real Fazenda, em 24 de novembro de 1798 o grupo de negociantes portugueses obteve prorrogação por mais $\underline{\text { seis anos do contrato da } \text { Bahia }^{479} \text {, com o mesmo preço e condições do contrato }}$ anterior $^{480}$.

Além de a coroa portuguesa querer controlar o lucro do contrato do dízimo concedendo-lhe como "mercê" ao grupo de negociantes portugueses em troca de sucessivos empréstimos e donativos, parece evidente que o que estava subjacente à prorrogação da arrematação concedida por decreto real era afastar a concorrência dos negociantes da Bahia que, como se teve oportunidade de demonstrar, barravam qualquer tipo de controle mais efetivo da coroa portuguesa em suas operações, mesmo que isso significasse a não obtenção de maiores lucros para o Real Erário.

A reação dos negociantes da Bahia diante dessa situação não chega a surpreender. Depois de vários requerimentos enviados à coroa portuguesa sem

\footnotetext{
477 Idem, p. 454.

${ }^{478}$ APUD, Fernando Dores Costa, p. 455.

${ }^{479}$ Ibidem, p. 456, grifo meu.

480 ANRJ - Correspondência da Bahia sobre cobrança dos dízimos reais, compra de escravos e sobre outros assuntos, Códice 91, (1789-1807), Secretaria de Estado do Brasil, 86; p. 33, 33v, 34, 34v, 35, 35v, 36. Grifos meus.
} 
respostas, os negociantes soteropolitanos Manoel Joaquim Álvares Ribeiro, José Cerqueira Lima, José da Silva Maya, João Barbosa de Madureira, Domingos José de Carvalho e Francisco Dias Coelho, em 23 de abril de 1799, enviaram uma extensa carta à coroa portuguesa e à Junta de Fazenda da Bahia, afirmando que:

"manifestamente dá a ver a lezão enormíssima com que pelo dito Ferreira foi intentada similhante arrematação, mayormente achando-se os suplicantes certificados pelo testemunho indefectível de outra anterior ordem de Vossa Magestade, que os lanços dos Comerciantes desta Praça deverião com antecedência àquelles subir à Real Presença e Vossa Magestade pelo Erário Régio, para serem preferidos pelo augmento: suposição que não sem aparências de dolo prevenio e acautelou o dito Ferreira, como opposta ao seu particular e excessivo interesse, antecipando as deligências desta arrematação, antes que pela Junta da Fazenda Real fossem remetidos os Lanços dos Suplicantes, ou a certeza de que não lançavão",481.

Os negociantes soteropolitanos argumentaram que a Real Fazenda poderia lucrar muita mais se empregasse as novas formas de cobrança do dízimo, cujo método foi delineado por d. Rodrigo de Sousa Coutinho, considerando-se o aumento da produção de todos os gêneros e da população que os consumia naquele final de século ${ }^{482}$. Em seguida, em nome do grave prejuízo do Estado e da Real Fazenda e em favor das urgentes despesas cada vez maiores na capitania da Bahia, os negociantes soteropolitanos solicitaram que a coroa portuguesa os preferisse:

"na dita Arrematação dos Dízimos Reaes desta Capitania pela mayoria de hum milhão de cruzados que os Suplicantes offerecem alem do preço actual em lugar dos cento e oitenta contos de reis que nos referidos seis annos prometeu pagar o dito Antônio José Ferreira, ou os dous milhões de cruzados se entenda como augmento de preço, pago nesta Capitania com os mais quarteis de contracto, ou com o donativo satisfeito no Real Erário em seis pagamentos iguaes de secenta e seis contos, seis centos secenta e seis mil, seis centos secenta e seis reis em cada dos annos do referido Contracto, segundo Vossa Magestade parecer útil",483.

\footnotetext{
${ }^{481}$ Idem.

${ }^{482}$ Ibidem.

${ }^{483}$ Ibidem.
} 
O parecer da Junta de Fazenda, assinado por Francisco Gomes de Souza, denunciado constantemente por Vilhena por práticas pouco ortodoxas com Manuel José Vilella de Carvalho ${ }^{484}$ na condução dos negócios da capitania da Bahia, datado de 18 de maio de 1799, advogava que se a diferença entre os lances dos negociantes portugueses e soteropolitanos consistisse em apenas trinta ou quarenta contos de réis, a Junta nem receberia o referido requerimento. No entanto, "o grande excesso de quinhentos $e$ cincoenta mil cruzados, que vem resultar de hum a outro Lanço: o mayor projecto que por similhante offerecimento recebeo a mesma Junta", obrigou-os a solicitar à coroa portuguesa a revisão da prorrogação concedida ao grupo de negociantes portugueses, em nome da Real Ordem de 29 de fevereiro de 1792, que previa os lances em hasta pública e uma "escrupuloza averiguação sobre a abonação e fundos dos Negociantes assinados" 485 .

Segundo Francisco Gomes de Souza, ainda que os negociantes soteropolitanos suplicantes fossem de mediana abonação e fundos, o que não era o caso mesmo que não fossem das mais antigas casas de comércio da Bahia ${ }^{486}$, eram pessoas bem estabelecidas e acreditadas pelo grosso giro do comércio e vultosos cabedais que possuíam, e consignatários da "attestação" sobre as excelentes condições da propriedade do Secretário de Estado e Governo do Brasil, José Pires de Carvalho e Albuquerque, para a arrecadação do tabaco e instalação da Mesa de Inspeção ${ }^{487}$, muito provavelmente como uma tentativa de controlar a arrecadação de um contrato também arrematado pelos negociantes portugueses Joaquim Pedro Quintela e o próprio António José Ferreira ${ }^{488}$.

Assim, o presidente da Junta de Fazenda argumentou que se estimava naquele final de século que os mesmo dízimos poderiam render duzentos contos de réis/ano livre de todas as despesas, de maneira que, com os negociantes soteropolitanos, a Real

\footnotetext{
${ }^{484}$ Manoel José Vilella de Carvalho era um dos proprietários dos escravos entregue à justiça durante a investigação da Conjuração Baiana de 1798.

${ }^{485}$ ANRJ - Correspondência da Bahia sobre cobrança dos dízimos reais, compra de escravos e sobre outros assuntos, Códice 91, (1789-1807), Secretaria de Estado do Brasil, 86; p. 42, 42v.

${ }^{486}$ De acordo com Francisco Marques de Góes Calmon, José Cerqueira Lima, por exemplo, era traficante de escravos, proprietário de 16 navios no período de 1822 a 1839 e possuía seu palácio no atual Corredor da Vitória, local de preferência dos residentes ingleses após 1808, e que, após transformação, tornou-se residência dos Presidentes da Província, sede da Secretaria da Educação e Saúde e, atualmente, abriga o Museu de Arte da Bahia. Seus móveis e alfaias mobiliaram o Palácio do Governo durante a visita que D. Pedro II fez à cidade em 1859. Cf. Francisco Góes Calmon. Vida Econômico-Financeira da Bahia. Salvador: CPE, 1978, p. 61.

${ }^{487}$ AHU_CU_CA, Baía, doc. 12701.

${ }^{488}$ Cf. Jorge Miguel Pedreira. Tratos e contratos: actividades, interesses e orientações dos investimentos dos negociantes da praça de Lisboa (1755-1822). Análise Social,, vol. XXXI (136-137), 1996 (2. $\left.{ }^{\circ}-3 .^{\circ}\right)$, 355-379, p. 9; Catherine Lugar, The Merchant Community of Salvador, Bahia, 1780-1830, Ann Arbor, 1980, pp. 141-144.
} 
Fazenda teria um prejuízo de trezentos contos de réis nos seis anos e, com o grupo de Antônio José Ferreira, o prejuízo chegaria a quinhentos e trinta e cinco contos de réis ${ }^{489}$. Além disso, o presidente da Junta lembrou que, em 23 de maio de 1797, havia solicitado a permissão de poder administrar os dízimos para a Real Fazenda, alegando que poderia aumentar as rendas reais fazendo a cobrança do açúcar nos trapiches da mesma forma que se praticava com a cobrança do tabaco na casa de sua arrecadação, cuja propriedade era do Secretário de Estado e Governo do Brasil, José Pires de Carvalho e Albuquerque. Por fim, o presidente da Junta de Fazenda demonstrou os benefícios de arrematar o contrato do dízimo na capitania da Bahia:

"e como poderá esta Junta instruída pelos conhecimentos de tão edificantes exemplos deixar de solicitar os meyos de cooperar para tão úteis fins? Ou como poderão estes praticar sem socorro daquelles? Com que desprazer não vê a mesma Junta retardarem-se já soldos, ordenados, congrias, pagamentos os mais recomendados afora das grandes precisões que oprimem estes cofres. Que força não faz aos ecos da pobreza para tirar-lhe das mãos os provimentos com que devem ser socorridos os Navios da Real Coroa propostos a defesa Pública, sem já mais poder evitar a tardança (sic) com que são pagos? Que sentimentos a não penetrão quando pela mesma falta de meios se não adiantão os úteis estabelecimentos da Marinha, Madeiras, Salitre e outros, felizmente ordenados por Vossa Magestade e de que podem ser supcetíveis as mayores vantagens em benefício do Estado e da Real Fazenda. Que aflição, por assim dizer, de huma Não, ordenada a trex annos: O lamentável tratamento que sofrem os miseráveis soldados doentes no Hospital da Santa Casa e a perda de homens, que por esse mau curativo experimenta o Estado a falta de hum Hospital própria em que decentemente se tratem? E finalmente que outros muitos atrasos não padecem immenças dependencias desta Capitania para as quaes não só não tem bastado o recurso do empréstimo aberto por Determinação Régia, nem ainda os Rendimentos destinados às Remessas do Real Erário dessa Corte, de que esta Junta por indispensável precisão se tem valido [...]"490.

O governador da capitania da Bahia, d. Fernando José de Portugal e Castro, também intercedeu a favor dos negociantes soteropolitanos, corroborando os argumentos do presidente da Junta de Fazenda e advogando a favor da arrematação do contrato do dízimo ficar aos cuidados da Real Fazenda, como prescrevera em ofício de 24 de maio de 1797:

\footnotetext{
${ }^{489}$ Ibidem.

${ }^{490}$ Ibidem.
} 
"os dízimos reaes, actualmente contratados, podem tãobem produzir o augmento de 40 contos de réis annuaes e d'ahí para cima, ficando logo que acabe o presente Contrato, na administração da Fazenda Real e praticando-se a cobrança do assucar nos trapixes desta cidade, da mesma fórma, que se pratica a respeito do tabaco na Gaza da sua arrecadação, com rezerva somente dos ramos dos gados, miunças $e$ pescados, para serem vendidos em hasta publica, pelas suas respectivas freguezias, por não ser nestes praticável a cobrança pela Real Fazenda",491.

Além disso, para d. Fernando José de Portugal e Castro, o valor oferecido pelos negociantes da Bahia era muito vantajoso, pois poderia:

"suprir em parte a falta de meios que há para satisfazer as exorbitantes despesas com que se acha gravada a Thesouraria Geral, sendo com tudo muito mais conveniente, ser este contracto administrado pela mesma Real Fazenda, practicado àquele methodo de cobrança que antecedentemente lembrei a $V$. Exa , quando lhe expus em Carta de vinte e quatro de mayo de mil sete centos novente e sete os meios que ocorrerão para se aumentarem as Rendas Reais " $" 492$.

Após descrever as crescentes despesas extraordinárias da capitania da Bahia, muitas das quais em auxílio à Real Fazenda, d. Fernando José de Portugal e Castro chancelou o pedido da Junta de Fazenda para controlar o processo de arrematação do dízimo, afirmando:

"q. no caso que aquelas acertadas reflexoens $e$ tão interessantes ao Real Serviço não produzão efeito por the obstar o Régio Decreto em que se ordena a arrematação deste contracto ao sobredito Antônio José Ferreira e sócios que elle nomear, sirvão ao menos para regular a arrematação futura e para se conhecer a justa razão com que a mesma junta Representou muito anteriormente quando convinha para o aumento das Rendas Reais que este Contracto se administrasse por conta da Fazenda Real, com a vantagem da cobrança do Açúcar de que se vai aproveitar aquele Contractador por hum preço tão desproporcionado $e$ diminuto ${ }^{, 493}$.

\footnotetext{
${ }^{491}$ AHU_CU_CA, Baía, doc. 17352.

${ }^{492}$ ANRJ - Correspondência da Bahia sobre cobrança dos dízimos reais, compra de escravos e sobre outros assuntos, Códice 91, (1789-1807), Secretaria de Estado do Brasil, 86; doc. 533, p. 21, 21v, 22, 22v, $23,23 \mathrm{v}$. Grifo meu.

${ }^{493}$ Idem.
} 
Até o momento, não foi possível verificar a reação dos negociantes da capitania de Pernambuco em relação à prorrogação da arrematação do contrato do dízimo por decreto real para o grupo de negociantes portugueses, mas em uma carta de d. João VI ao bispo Azeredo Coutinho e aos governadores interinos da capitania de Pernambuco sobre os dízimos da Bahia, datada de 28 de julho de 1801, solicitou-se ao bispo da capitania de Pernambuco:

"que logo que receberdes esta Minha Carta Régia, mandeis immediatamente por em Lanços todos e quaes quer Contractos Reaes; o que executareis não só pelo que respeita a casa hum em totalidade, mais ainda divididas em Ramos, ou pequenas porções com a condição de prestarem os Arrematadores bons Fiadores e de pagarem cada quartel adiantado, dentro do praso de quinze dias, depois que o mesmo quartel houver principiado $[\ldots]^{494,}$.

Àquela altura, a coroa portuguesa reconheceu a pertinência do requerimento dos negociantes soteropolitanos, chancelados pela representação da Junta de Fazenda e pela carta do governador da capitania da Bahia:

"pelo facto de o Contracto dos Dízimos da Bahia, que quando se julgasse ter se arrematado com vantagem, se reconheceo pela zelosa e justa Representação Junta da Real Fazenda da mesma Capitania o prodigioso augmento que a mesma Renda teria sendo Administrada por conta da Fazenda Real; e como se vê até verificado pelo augmento que teve esse Rendimento só na parte das Miunças, que se mandou arrematar "495.

Não obstante o reconhecimento da coroa portuguesa sobre o aumento das rendas reais com os contratos administrados pela Real Fazenda, Bruno Aidar demonstra que para a capitania de São Paulo, o contrato do dízimo foi arrematado novamente a Jacinto Fernandes Bandeira ${ }^{496}$, por mais dois triênios consecutivos a partir de novembro de 1798, exatamente como aconteceu na capitania da Bahia com Antônio José Ferreira. A diferença para a capitania de São Paulo é que nem os negociantes locais, nem os arrazoados do governador Mello e Castro e nem o Alvará de 12 de junho de 1800 no qual d. Rodrigo de Sousa Coutinho anulou todas as prorrogações das arrematações das

\footnotetext{
494 Arquivo Histórico do Itamaraty, doravante, AHI, Lata 184, Maço 1, Pasta 8. Carta dirigida ao Reverendo Bispo de Pernambuco e aos Governadores Interinos da Capitania de Pernambuco pelo Príncipe de Portugal acerca dos Dízimos da Bahia, 1801. 495 Idem.

${ }^{496}$ Sócio de Antônio José Ferreira em outros contratos.
} 
rendas e contratos reais foram suficientes para impedir que Jacinto Fernandes Bandeira controlasse o contrato dos dízimos da capitania de São Paulo até $1803^{497}$.

Para o caso da capitania da Bahia, no entanto, Fernando Dores Costa demonstra que Antônio José Ferreira foi obrigado a abandonar o contrato do dízimo, ficando anulado não só a cláusula do donativo, cuja primeira prestação de 30 contos já havia sido paga ao Erário Régio, como também o empréstimo gratuito de 50 contos que ele e seus sócios fizeram à coroa portuguesa em 28 de agosto de 1798, aprovado por um decreto régio de 2 de março de $1797^{498}$. Entretanto, como importante capitalista português, em 1802, a coroa portuguesa indenizou Antônio José Ferreira pelo donativo e pelo empréstimo, pagando-o 80 contos em apólices. Além disso, o Alvará de 6 de janeiro de 1802 confirmou todas as condições exigidas por um grupo de negociantes portugueses - entre os quais: Jacinto Fernandes Bandeira e Antônio José Ferreira - para a criação da Real Companhia ao novo estabelecimento para as fiações e torcidos das sedas, com duração inicial de 12 anos, podendo ser prorrogáveis, concedendo-lhes também muitos privilégios, entre eles a mercê do hábito de Cristo e a possibilidade de os negociantes reputarem-se nobres para serem admitidos nos empregos honoríficos ${ }^{499}$.

As implicações que envolvem a contenda entre os negociantes portugueses e os negociantes soteropolitanos acerca da prorrogação do contrato do dízimo na capitania da Bahia - com a reiterada exclusão dos negociantes soteropolitanas nesse processo para a história da Conjuração Baiana de 1798 são algumas. Em primeiro lugar, o grupo de negociantes da Bahia que ofereceu vultosos donativos anuais e 1 milhão de cruzados pela arrematação do contrato do dízimo é composto por homens com íntimas relações com a corporação dos enteados, grupo que fez "pronta-entrega" de seus escravos à justiça durante as investigações da Conjuração Baiana de 1798, comandado pelo Secretário de Estado e Governo do Brasil, José Pires de Carvalho e Albuquerque.

A análise sobre as devassas de residência tiradas nos últimos anos do século XVIII na capitania da Bahia são paradigmáticas nesse sentido, pois comprovam o alinhamento político e econômico entre negociantes nascidos na Bahia e negociantes reinóis que residiam na capitania. É o caso, por exemplo, da devassa de residência do desembargador do Tribunal da Relação da Bahia, Thomaz Ignácio de Moraes Sarmento,

\footnotetext{
${ }^{497}$ Cf. Bruno Aidar, A tessitura do fisco, op.cit., pp. 128-130.

${ }^{498}$ Fernando Dores Costa, op.cit., p. 456.

${ }^{499}$ Cf. Anais da Biblioteca Nacional, doravante ABN, vol. 68, 1949, p. 1021.
} 
cujas atestações de zelo e "inteireza limpeza de mãos" sobre a condução do desembargador foram assinadas por:

\section{Perfil das testemunhas da Devassa de Residência do Desembargador Thomaz Ignácio de Moraes Sarmento ${ }^{500}$}

\begin{tabular}{|c|c|}
\hline Nome & Ocupação \\
\hline Inocêncio José da Costa & $\begin{array}{l}\text { Professo na Ordem de Cristo, Tenente } \\
\text { Coronel do Regimento dos Úteis, Tesoureiro } \\
\text { Geral da Administração da Junta da Real } \\
\text { Fazenda, Negociante, Traficante de escravos, } \\
\text { Natural de Lisboa. }\end{array}$ \\
\hline Agostinho José Barreto & $\begin{array}{l}\text { Negociante e Administrador dos Direitos da } \\
\text { Alfândega da Bahia, Natural do Minho. }\end{array}$ \\
\hline Teodoro Gonçalves Silva & $\begin{array}{l}\text { Professo na Ordem de Cristo, Mestre de } \\
\text { Campo do Regimento Auxiliar da Bahia, } \\
\text { Negociante, Natural da cidade do Porto. }\end{array}$ \\
\hline Antônio Alvares de Figueiredo & $\begin{array}{l}\text { Bacharel formado pela Universidade de } \\
\text { Coimbra, Advogado nos Auditórios da Bahia, } \\
\text { Natural de Pernambuco. }\end{array}$ \\
\hline Adriano de Araújo Braga & $\begin{array}{l}\text { Negociante, Administrador do Celeiro } \\
\text { Público de 1796-1800, Traficante de escravos, } \\
\text { Natural de Braga. }\end{array}$ \\
\hline Antônio Barbosa de Oliveira & $\begin{array}{l}\text { Tabelião e Escrivão Público do Judicial, } \\
\text { Advogado de defesa dos réus da Conjuração }\end{array}$ \\
\hline
\end{tabular}

500 AHU_CU_CA, Baía, docs: 15268-15269. “Officio do governador D. Fernando José de Portugal e Castro para Martinho de Mello e Castro no qual se refere à Devassa de Residência do Desembargador Thomaz Ignácio de Moraes Sarmento e participa sua partida para o Reino por ter acabado o tempo de serviço na Relação da Bahia. Bahia, 20 de abril de 1793". Cumpre destacar que as várias devassas de residências tiradas nos anos finais do século XVIII contam com os testemunhos de praticamente os mesmos homens, alternando-se apenas com Francisco Vicente Viana e Manuel José Vilella de Carvalho, proprietários de escravos entregues à Conjuração Baiana de 1798, e José Cerqueira Lima e Domingos José de Carvalho, sócios do grupo de negociantes da Bahia que ofereceu 1 milhão de cruzados para a arrematação do contrato do dízimo pelo triênio de 1800-1803, conforme os documentos, respectivamente: AHU_CU_CA, Baía, Caixa 81, doc: 15698 "Autos da Devassa de Residência do Desembargador da Relação da Bahia Jozé Theotônio Sedron Zuzarte. Bahia, 18 de julho de 1794”; Arquivo Público Theodoro Sampaio do Instituto Geográfico e Histórico da Bahia, doravante AHTS/IGBa, Caixa 001: "Original de atestado passado por D. Rodrigo José de Menezes do Concelho de Sua Magestade Fidelíssima, Governador e Capitão General da Capitania da Bahia, informando o modo pelo qual Francisco Vicente Viana se conduziu no lugar de Ouvidor da Bahia”. 


\begin{tabular}{|c|c|}
\hline & $\underline{\text { Baiana de 1798, Natural da Bahia. }}$ \\
\hline João Barbosa de Madureira & $\begin{array}{l}\text { Negociante e sócio do grupo que ofereceu } 1 \\
\text { milhão de cruzados para a arrematação do } \\
\text { contrato dos dízimos, em } 1800 \text { ganhou a } \\
\text { mercê da propriedade da Sesmaria com três } \\
\text { léguas de terra, na freguesia de Itabaiana, } \\
\text { comarco de Sergipe D’El Rei }{ }^{501} \text {, autor de } \\
\text { várias atestações, junto com Inocêncio José da } \\
\text { Costa, sobre o comportamento dos oficiais da } \\
\text { capitania da Bahia }^{502} \text {. Natural da Bahia. }\end{array}$ \\
\hline Manuel Pereira Dias & $\begin{array}{l}\text { Bacharel Formado pela Universidade de } \\
\text { Coimbra, Advogado nos Auditórios da cidade } \\
\text { da Bahia, Natural da Bahia. }\end{array}$ \\
\hline José Antônio do Vale & $\begin{array}{l}\text { Bacharel Formado pela Universidade de } \\
\text { Coimbra, Advogado nos Auditórios da cidade } \\
\text { da Bahia, Natural da Bahia. }\end{array}$ \\
\hline Alexandre Antônio de Sousa & $\begin{array}{l}\text { Cavaleiro Fidalgo da Casa de S. Majestade, } \\
\text { Sargento-mor do Regimento de Infantaria da } \\
\text { Bahia, Natural de Lisboa. }\end{array}$ \\
\hline Francisco Gomes de Sousa & $\begin{array}{l}\text { Cavaleiro Fidalgo da Casa de S. Majestade, } \\
\text { Escrivão da Junta da Real Fazenda, } \\
\text { Negociante, Natural da Bahia. }\end{array}$ \\
\hline Manoel José Fróes & $\begin{array}{l}\text { Professo na Ordem de Cristo, Negociante, } \\
\text { Natural de Alcobaça. }\end{array}$ \\
\hline Manoel Tomé Jardim de Souza Uzel & $\begin{array}{l}\text { Escrivão de um dos Ofícios da Ouvidoria } \\
\text { Geral do Cível da Relação da Bahia, Natural } \\
\text { de São Francisco do Sergipe do Conde. }\end{array}$ \\
\hline Bernardino de Sena e Araújo & $\begin{array}{l}\text { Tabelião e Escrivão Público Judicial e Notas } \\
\text { da Bahia, Juiz dos Órfãos, Proprietário de } \\
\text { escravos entregues à justiça na Conjuração }\end{array}$ \\
\hline
\end{tabular}

${ }^{501}$ AHU_CU_CA, Baía, doc. 24236. Alvará pelo qual o Governador D. Fernando José de Portugal concedeu e deu de sesmaria ao Capitão João Barbosa Madureira três legoas de terra situadas na freguezia de Itabaiana, comarca de Sergipe d'Elrei. Bahia, 15 de setembro de 1800. (Annexo ao n. 24.236).

${ }^{502}$ AHU_CU_CA, Baía, doc. 36031. 


\begin{tabular}{|l|l|}
\hline Vicente Ferreira Antunes & $\underline{\text { Baiana de 1798, Natural da Bahia. }}$ \\
\hline Caetano Maurício Machado & $\begin{array}{l}\text { Escrivão da Conservatória dos Moedeiros da } \\
\text { Bahia, Natural da Bahia. }\end{array}$ \\
\hline $\begin{array}{l}\text { Professo na Ordem de Cristo, Sargento-mor } \\
\text { Úteis, Ajudante de Ordens do Governo da } \\
\text { Capitania da Bahia, Proprietário de escravos } \\
\text { entregues à justiça na Conjuração Baiana de }\end{array}$ \\
\hline$\underline{1798}$, Natural de Lisboa. \\
\hline
\end{tabular}

Em segundo lugar, o fato de o negociante português Antônio José Ferreira ter sido obrigado a desistir da prorrogação do contrato do dízimo em razão da pressão exercida pelos negociantes soteropolitanos, com apoio da Junta de Fazenda, do governador da capitania da Bahia e do posterior reconhecimento de d. João VI sobre a pertinência dessas reivindicações, demonstra a consolidação dos interesses dos negociantes soteropolitanos na última década do século XVIII no Império Português, muito provavelmente favorecida pela comunhão com os interesses dos negociantes reinóis estabelecidos na capitania da Bahia.

Para além de o embate entre os negociantes portugueses e os negociantes soteropolitanos comprovar que a consolidação efetiva dos interesses dessas comunidades era viabilizada pelo grande lucro obtido com as arrematações dos impostos no Império Português ${ }^{503}$ - o argumento do presidente da Junta de Fazenda foi sobre o menor prejuízo da coroa portuguesa e não sobre o maior lucro -, o desfecho desse embate demonstra a inviabilização política e econômica de implantação das reformas modernizadoras de d. Rodrigo de Sousa Coutinho no final do século XVIIImesmo quando os negociantes soteropolitanos, a Junta de Fazenda e o próprio governador da capitania da Bahia valeram-se do argumento do Ministro para defender que as arrematações fossem administradas pela Real Fazenda, à época, controlada por Francisco Gomes de Sousa e Inocêncio José da Costa, pessoas íntimas do grupo do Secretário de Estado e Governo do Brasil, José Pires de Carvalho e Albuquerque.

Embora a coroa portuguesa tivesse revogado a prorrogação do contrato do dízimo na Bahia para Antônio José Ferreira, ela o fez depois de deflagrada a Conjuração

\footnotetext{
${ }^{503}$ Cf. Jorge Miguel Viana Pedreira. Estrutura industrial e mercado colonial: Portugal e Brasil (17801830). Lisboa: Difel, 1994.
} 
Baiana de 1798 e mediante donativo anual oferecido a Real Fazenda pelos negociantes da Bahia - muitos dos quais credores da coroa portuguesa -, e mediante também a concessão de privilégios para os negociantes portugueses, com a criação de uma companhia de comércio têxtil e a concessão de títulos honoríficos, como uma espécie de prêmio de consolação, cujos esforços cairiam por terra em $1810^{504}$.

A manutenção da concessão de privilégios, como se sabe, era um dos principais pontos combatidos pelas reformas de d. Rodrigo de Sousa Coutinho e ponto central para a manutenção do pacto colonial, esfera na qual a coroa portuguesa efetivamente controlava naquele final do século XVIII, de tal sorte que, "a bem das circunstâncias", deixou à margem do processo de arrematação do contrato do dízimo da capitania da Bahia os negociantes portugueses a partir de 1800. Essa situação, portanto, é paradigmática das implicações das transformações econômicas de meados do século XVIII que possibilitou a consolidação da comunidade mercantil colonial, mas não criou condições necessárias para mudanças mais profundas das estruturas sociais e econômicas de Portugal, no sentido de consolidar seu desenvolvimento industrial e um grupo capitalista autônomo ${ }^{505}$.

Nesse sentido, a situação ocorrida no final do século XVIII na capitania da Bahia demonstra, a um só tempo, que os negociantes portugueses tenderiam a perder espaço no controle de setores estratégicos para a manutenção do pacto colonial e que a sobrevida econômica da coroa portuguesa dependeria, cada vez mais, da consolidada comunidade de negociantes soteropolitanos, que passaram a se organizar para controlar esses setores e obtiveram apoio do governador da capitania da Bahia e da própria coroa portuguesa, que àquela altura não tinha condições de prescindir do capital desses negociantes para cobrir as receitas extraordinárias cada vez maiores com 0 recrudescimento do conflito entre as nações europeias e a dinamização da marinha portuguesa.

Ao mudar os agentes do processo e não o processo em si, a própria coroa portuguesa impôs os limites para a concretização das reformas de d. Rodrigo de Sousa

\footnotetext{
${ }^{504}$ Embora a coroa portuguesa tivesse incentivado os negociantes portugueses na dinamização de sua industrialização, como foi o caso do negociante Antônio José Ferreira e seus sócios, essa situação durou até o Tratado de 1810, que afetou decisivamente a industrialização portuguesa com o fim do pacto colonial, conforme Valentim Alexandre, op.cit., p. 785.

${ }^{505}$ Cf. Fernando Antônio Novais. Brasil e Portugal ..., op.cit; Francisco Falcon. A época pombalina. São Paulo:Ática, 1983; Jorge Borges de Macedo. A situação econômica no tempo de Pombal. Lisboa: Gradiva, 1985; Jorge Pedreira, Os homens... op. cit.; Kenneth Maxwell. Marquês de Pombal - paradoxo do iluminismo. Rio de Janeiro: Paz e Terra, 1996.
} 
Coutinho, cuja implantação comprometeria, entre outras coisas, o aumento das rendas reais obtidas por práticas como a arrematação dos contratos vinculada aos donativos anuais $^{506}$. Ao impor os limites à concretização de itens estratégicos das reformas de $\mathrm{d}$. Rodrigo de Sousa Coutinho, afastando a retórica da modernização e optando pela permanência das políticas mercantilistas e absolutistas, a coroa portuguesa acabou reforçando seu próprio poder na medida em que continuou a governar a conflitualidade no interior dos setores dominantes do reino e da sua principal colônia.

Ademais, cumpre destacar que a opção de participação da comunidade mercantil colonial, em especial a da capitania da Bahia, no desenvolvimento manufatureiro da colônia não estava no horizonte de expectativas desses homens por ocasião do proibitivo Alvará de $1785^{507}$. Embora as prerrogativas do Alvará visassem resguardar condições para o incremento da industrialização portuguesa, a documentação demonstra que a comunidade mercantil da capitania da Bahia ressentiu-se menos com a proibição manufatureira insignificante na colônia e muito mais com o recrudescimento em relação ao controle do comércio ilícito, com a reiterada prorrogação das arrematações dos contratos aos negociantes portugueses, deixando-os à margem do processo de arrematação dos contratos e com a possibilidade de perda dos privilégios conquistados com a implantação das reformas de d. Rodrigo de Sousa Coutinho.

O projeto de prover o Brasil de modernização econômica e financeira não foi capaz de conquistar a adesão da consolidada comunidade mercantil da Bahia, que operava em comunhão com a corporação dos enteados para manter-se no poder teimosamente agarrada ao ethos aristocrático e aos privilégios conquistados ${ }^{508}$.

\footnotetext{
${ }^{506}$ Ao analisar o fracasso na implantação das reformas de Turgot no último quartel do século XVIII, na França, Hobsbawm afirma que muitas tentativas de reformas fracassavam porque "ou eram inaplicáveis, e, portanto, meros floreios teóricos, ou então improváveis de mudar o caráter geral de suas estruturas político-sociais; ou ainda fracassaram em face da resistência das aristocracias locais e de outros interesses estabelecidos, deixando o país recair em uma versão um pouco mais limpa do seu antigo Estado". Cf. Eric J. Hobsbawm. A Era das Revoluções (1789-1848). Rio de Janeiro: Paz \& Terra, 1980, p. 40.

507 Sobre as implicações na colônia do proibitivo Alvará de 17985, ler: Fernando Antônio Novais. A proibição das manufaturas no Brasil e a política econômica portuguesa do fim do século XVIII. Revista de História 142-143 (2000), 213-237.

508 Trata-se de uma lógica de reiteração da diferença na qual o privilégio é o ordenador natural da sociedade de Antigo Regime. Conforme demonstra Nuno Monteiro, na Europa Moderna, não só o sangue, mas também os serviços, as letras e as mercês poderiam incluir os indivíduos na condição dos privilegiados. Para o caso do período colonial brasileiro, Maria Beatriz Nizza da Silva afirma que esse processo de enobrecimento dependia da graça ou mercê régia para existir. A bibliografia sobre o tema é vasta, mas se deve ler, especialmente: Maria Beatriz Nizza da Silva. Ser nobre na colônia. São Paulo: Editora UNESP, 2005, p.18; Nuno Gonçalo Monteiro. O 'Ethos' Nobiliárquico no final do Antigo Regime: poder simbólico, império e imaginário social. Almanack Braziliense. São Paulo, n.2, novembro de 2005, pp. 4-20; Nuno Gonçalo Monteiro. Poder senhorial, estatuto nobiliárquico e aristocracia. In: Antônio Manuel Hespanha (Org.). História de Portugal: o Antigo Regime. Lisboa: Editorial Estampa,
} 
Qualquer ameaça a esse projeto de manutenção de poder, portanto, encontraria resistência com farto suporte material às suas reivindicações, como de fato aconteceu. 


\subsection{Os Boletins Manuscritos: demandas e agentes políticos}

Na manhã de 12 de agosto de 1798, dez boletins manuscritos foram afixados em locais públicos da cidade de Salvador, convocando a população para uma "revolução" que implantaria a "República Bahinense" e Republicano ordena, manda e quer que para o futuro seja feita a sua digníssima $\underline{\operatorname{Revoluc} \tilde{a} \boldsymbol{o}} " 510$. O conteúdo dos boletins, intitulados de "Avisos" e elaborados pelo "Partido da Liberdade", composto pelos "Anônimos Republicanos" tocava em alguns pontos extremamente delicados para as autoridades nos dois lados do Atlântico.

Das informações das cópias dos boletins manuscritos, pelo arrolamento contido no Aviso n..$^{\circ}$ 1, sabe-se que do total de 676 adeptos ao levante, 513 pessoas pertenciam a corporações militares, das quais 187 eram oficiais, inferiores e soldados da Tropa de Linha, e 326 pertenciam às Milícias. Segundo a mesma fonte, o restante de adeptos ao levante dividia-se em 13 homens graduados em letras, 20 homens do comum, 8 homens do comércio, 8 frades bentos, 14 franciscanos, 3 barbadinhos, 14 terésios, 48 clérigos e 8 familiares do Santo Ofício. A substancial presença dos homens que pertenciam às corporações militares além de demonstrar a importância de se ter homens armados para o levante, explica as razões pelas quais a principal reivindicação presente nos boletins era o aumento do soldo para 200 réis diários e isonomia nos critérios de ascensão na hierarquia militar da colônia ${ }^{511}$.

De acordo com a carta do provedor da Casa da Moeda, José Venâncio de Seixas, enviada a d. Rodrigo de Sousa Coutinho ${ }^{512}$, em 20 de outubro de 1798, os habitantes da cidade de Salvador, em sua maioria, eram negros, mestiços ou mulatos trabalhadores manuais empregados nos mais variados e menos prestigiados ofícios. Grande parte do contingente do "povo mecânico", a partir de uma série de reformas iniciadas por

\footnotetext{
${ }^{509}$ Os originais dos boletins manuscritos encontram-se no Arquivo Público do Estado da Bahia, APEB, Cartas do Governo a Sua Majestade, 1787-1797, v. 138, fols. 372-383. Os boletins manuscritos encontram-se na Seção Histórica dos volumes 578 e 581 do APEB. A cópia dessa documentação encontra-se publicada na Coleção Martins, BN-I-28, 23, $\mathrm{n}^{\mathbf{0}}$ 1-12. Os boletins manuscritos foram transcritos nos Anais do Arquivo Público da Bahia, vol. 36, pp. 373-378 e na obra de Braz do Amaral “Conspiração Republicana da Bahia, 1798”. Rio de Janeiro: Imprensa Nacional, 1926, pp. 40-45.

510 Grifo meu. Chamo atenção para o tempo futuro da "revolução" que seria feita na Bahia. Essa mensagem está presente nos boletins manuscritos de número 4, 5, 6, 7, 8 e 10. Cf. Kátia M. de Queirós Mattoso. Presença Francesa no Movimento Democrático Baiano de 1798. Salvador: Itapuã, 1969, pp. 149-159.

511 Idem.

512 Cf. Carta de José Venâncio de Seixas para D. Rodrigo de Souza Coutinho, em que lhe participa ter chegado à Bahia e ter tomado a posse do lugar de Provedor da Casa da Moeda, referindo-se a diversos assumptos de serviço público e especialmente à descoberta de uma associação sediciosa de mulatos. Bahia, 20 de outubro de 1798. AHU_CU_, BAÍA, CA_doc. 18433.
} 
Pombal, foi incorporada progressivamente à força militar, de tal sorte que todos os brancos sem nenhum ofício, mulatos forros e negros libertos tinham praça nos diversos corpos, tanto da tropa de linha como das milícias urbanas ${ }^{513}$. Diante do recrutamento das gentes, muitas vezes à força, com castigo físico, fome, ausência de pagamento de soldo, José Venâncio é mais um dos que, à época, assemelham o recrutamento militar à escravidão, condição da qual estavam muito próximos.

Não à toa, o provedor da Casa da Moeda via nessa situação a razão para alguns dos tumultos e motins que encontrara na Salvador de 1798. Para José Venâncio, os tumultos dos milicianos das tropas urbanas eram decorrentes das políticas adotadas pelo Marquês de Pombal, especialmente no que se refere ao recrutamento de pardos, mulatos e pretos, pois:

"a Carta Régia de 1766 foi segundo me parece hum erro de
política em administração de colonias, porque mandando
formar corpos milicianos desta qualidade de indivíduos
[pardos, mulatos e negros], se viram condecorados com
postos de coronéis e outros similhantes, com que esta gente
naturalmente persuadida, adiantou consideravelmente as suas
idéias vaidosas, o que junto ao espírito do século, os faz
romper em toda a qualidade de excessos"

José Venâncio de Seixas refere-se aos desdobramentos da carta régia de 22 de março de 1766, do rei D. José I, que dava bases para a reorganização das tropas de segunda e terceiras linhas. Uma das principais instruções da carta régia de 1766 foi a instituição às milícias de cor de todas as honras, graças, franquezas, liberdades, privilégios e isenções que gozavam os capitães das tropas pagas, normalmente composta por brancos e portugueses. Para Kalina Vanderlei Paiva da Silva, entretanto:

"na prática é difícil acreditar que os milicianos chegassem a ter realmente os mesmo privilégios e honras dos oficiais portugueses, mas com a institucionalização das milícias de

\footnotetext{
${ }^{513}$ Miguel Antônio de Melo, Conde de Murça. Informaçam sobre a Bahia. Agradeço a Nelson Mendes Cantarino a indicação e cópia do documento. Em forma de carta, o documento foi escrito em 30 de março de 1797, embora haja à esquerda uma observação de d. Rodrigo de Souza Coutinho "remeteu-se ao governador da Bahia um extrato desta carta, sem o nome de quem a escreveu, em setembro de 1798". Apesar da data, não há nenhuma referência à revolta baiana de 1798. O autor do manuscrito, todavia, descreve minuciosamente a situação da Salvador da época decorrente do que ele chama de "frouxidão" do governador, d. Fernando José de Portugal e Castro. Há uma cópia do documento na Biblioteca Nacional do Rio de Janeiro, Divisão de Manuscritos, I-31, 21, 34, doc. 1 e 2. Há uma cópia microfilmada cuja indicação é AHU_CU_Baía, caixa 205, doc. 14690. Guilherme Pereira das Neves afirma a existência de outra cópia da carta no IHGB, lata 358, pasta 28 e traz a data de 30 de março de 1797 . Cf. Guilherme Pereira das Neves. Em busca de um ilustrado: Miguel Antônio de Melo (1766-1836). Acessado em 10 de janeiro de 2007 no sítio: www.realgabinete.com.br

514 José Venâncio de Seixas, doc. cit., grifo meu.
} 
cor, a Coroa cria a expectativa de posse dos ditos privilégios, além de permitir, involuntariamente, formas de ascensão para negros e pardos militares" 515 .

De qualquer forma, para José Venâncio, o Alvará de 1766 abriu uma possibilidade até então inexistente que poderia levar a que esses homens negros, pardos e mulatos cometessem excessos, como foi o perigo em que estiveram os habitantes da Salvador com a descoberta de:

"huma associação sediciosa de mulatos, que não podia deixar de ter perniciosas conseqüências, sem embargo de ser projectada por pessoas insignificantes; porque para se fortificarem lhes bastavam os escravos domésticos inimigos irreconciliáveis de seus senhores, cujo jugo por mais leve que seja lhes he insupperavel",516.

Talvez seja por essa razão que José Venâncio sugere o retorno à situação em que as tropas urbanas e as ordenanças se encontravam antes da reforma de 1766, pois:

" $n$ 'esta ocasião que todas as ordens antigas dirigidas ao Brazil a respeito de mulatos, os fazia conservar em hum certo abatimento, prohibindo-lhes a entrada em qualquer officio publico ou posto militar, inhibição que era ampliada ainda mesmo aos brancos casados com mulatas,"517.

Ao relembrar a hierarquia militar na colônia, antes de 1776, José Venâncio encaminha sua carta alertando as autoridades para a necessidade de um recrudescimento político quanto à presença de pardos e mulatos nos corpos de milícias das tropas urbanas e à necessidade de recrudescimento dos critérios de ascensão social. A situação que se encontravam os milicianos na Bahia do final do século XVIII provavelmente explica o número de expressivo de suas presenças no "Partido da Liberdade", arrolados no "Aviso n" 1".

De acordo com a mesma fonte, o segundo grupo mais importante em termos numéricos de adeptos ao levante era composto por religiosos seculares e regulares, cujas corporações eclesiásticas eram muito mais sensíveis aos setores populares. Não parece ser por outra razão que o Prior dos Carmelitas Descalços tenha sido escolhido o chefe

\footnotetext{
${ }^{515}$ Cf. Kalina Vanderlei Paiva da Silva. Nas solidões vastas e assustadoras: os pobres do açúcar e a conquista do sertão de Pernambuco nos séculos XVII e XVIII. Tese de Doutoramento, UFPE, Recife, 2003, p. 183. Ler, especialmente o item 2.2 Henriques e Pardos: as milícias de cor, pp. 157-185.

${ }^{516}$ José Venâncio de Seixas, doc. cit. Grifo meu.

${ }^{517}$ Ibidem. Cabe ressaltar que a partir de Pombal o casamento entre brancos e negros ou brancos e índios não designava nenhum impeditivo para ascender na carreira burocrática ou na militar, embora na prática a situação fosse outra. Cf. Kalina Vanderlei Paiva da Silva, op.cit.
} 
da Igreja Bahinense, em uma das cartas encontradas na Igreja do Carmo, no dia 20 de agosto de 1798:

"Reverendíssimo em Christo Padre Prior dos Carmelitas Descalços: e para o futuro Geral em Chefe da Igreja Bahinense: segundo a secção do Plebiscito de 19 do corrente: quer e manda o Povo que seja feita a sua revolução nesta Cidade por conseqüência de ser exaltada a bandeira da igualdade, Liberdade, e fraternidade Popular, portanto manda que todo o sacerdote Regular e Irregular assim o aprove, e o en[ten] da alias. Vive et vale, 518 .

No entanto, entre os religiosos arrolados, cumpre destacar a ausência de cônegos, abades e superiores. Talvez seja por isso que uma das principais informações contida na maioria dos boletins manuscritos refere-se à punição "com morte natural de todo aquele e qualquer sacerdote que no púlpito, confessionário, exortação, persuadir aos ignorantes e fanáticos com o que for contrário a Liberdade e bem do Povo". Cumpre destacar, entretanto, o desprestígio e a decadência das ordens religiosas da capitania da Bahia no final do século XVIII, cujos quadros não se renovavam pelo recrudescimento das diretrizes do arcebispo da Bahia, d. Antônio de Corrêa e d. Rodrigo de Sousa Coutinho, que proibiam a entrada de noviças e noviços nas ordens religiosas $^{519}$.

Note-se que as questões relacionadas aos dois principais grupos arrolados entre os adeptos do levante dizem respeito a problemas muito concretos dos que viviam em uma sociedade onde tudo e todos se opunham. Os autores dos boletins manuscritos arrolaram também a presença de "homens graduados em postos e cargos", que muito provavelmente referem-se à participação de homens que gravitavam política e economicamente na órbita da corporação dos enteados, um grupo formado por sete homens e uma mulher, conforme a tabela abaixo:

\footnotetext{
${ }^{518}$ ADCA, vol.1, pp. 39-40.

${ }^{519}$ Além disso, Kátia M. de Queirós Mattoso chama atenção para o fato de que os clérigos seculares não eram providos nem com benefícios, nem com curas, nem com capelanias, de sorte que a principal característica desse grupo era a falta de homogeneidade material pelo amplo leque de remunerações desiguais entre os que exerciam o mesmo ofício. Esses desníveis provavelmente contribuíram para acirrar os ânimos entre os contemplados pelos favores do Estado e os que viviam situações difíceis. A esse respeito, ler: Kátia M. de Queirós Mattoso. Párocos e vigários em Salvador no século XIX: as múltiplas riquezas do clero secular da capital baiana. Tempo e Sociedade, Niterói, Vol. 1, nº 1, pp. 13-48, jan/jun. 1982; Kátia M. de Queirós Mattoso. Bahia, 1798: os panfletos revolucionários. Proposta de uma nova leitura. In: Osvaldo Coggiola (Org.). A Revolução Francesa e seu impacto na América Latina. São Paulo: EDUSP, 1990, pp. 341-356.
} 


\section{Relação dos proprietários dos escravos entregues à justiça durante as investigações da Conjuração Baiana de 1798, a corporação dos enteados:}

\begin{tabular}{|c|c|}
\hline Proprietários & Número de Escravos \\
\hline José Pires de Carvalho e Albuquerque & 4 \\
\hline Bernardino de Sena e Araújo & 1 \\
\hline Francisco Vicente Viana & 1 \\
\hline Caetano Maurício Machado & 1 \\
\hline Manoel José Villela de Carvalho & 2 \\
\hline Joaquim Pereira Bastos & 1 \\
\hline Paulino de Sá Tourinho & 1 \\
\hline Maria Francisca da Conceição e Aragão & 1 \\
\hline
\end{tabular}

ADCA, vol. II, pp. 812-816 ${ }^{520}$.

Para Kátia Mattoso, tanto as categorias compostas por "homens graduados em postos e cargos" quanto os "homens do comércio" compõem um contingente com contorno pouco preciso em relação às categorias mais expressivas ${ }^{521}$. No entanto, chama atenção o fato de haver entre as categorias sociais arrolados no Aviso $\mathrm{N}^{\circ} 1$ a presença de oito Familiares do Santo Ofício, cujo número coincide com a presença de oito "homens do comércio" e está muito próximo ao número de onze "homens graduados em postos e cargos". Considerando que a corporação dos enteados é formada por oito pessoas que entregaram seus escravos à justiça durante as investigações da Conjuração Baiana de 1798, pode-se afirmar com relativa tranquilidade que esse grupo está contido na categoria "homens graduados em postos e cargos".

Além disso, cumpre destacar que na capitania da Bahia do final do século XVIII têm-se os seguintes Familiares do Santo Ofício relacionados à Conjuração Baiana de $1798^{522}$, com o Secretário de Estado e Governo do Brasil e com o grupo de sócios de negociantes soteropolitanos que arremataram os dízimos da capitania da Bahia no final do século XVIII em detrimento ao grupo de negociantes portugueses, conforme tabela abaixo:

\footnotetext{
${ }^{520}$ ADCA, vol II, pp. 812-816: "Relação das pessoas que se achão prezas na cadea Desta Cidade da Bahia, por occazião dos factos revolucionários de que por Portaria do Ilmo. Governador desta Capitania Dom Fernando Jozé de Portugal, tem devassado o Dezembargador dos agravos da Relação desta mesma Cidade, o Doutor Francisco Sabino Álvares da Costa Pinto".

${ }_{521}^{521}$ Cf. Kátia M. de Queirós Mattoso. Bahia, 1798: os panfletos revolucionários, op.cit., p. 323.

${ }^{522}$ Agradeço a Aldair Carlos Rodrigues a prestimosa ajuda com as informações sobre a pesquisa dos Familiares do Santo Ofício da capitania da Bahia no final do século XVIII.
} 


\begin{tabular}{|c|c|}
\hline Familiares do Santo Ofício & $\begin{array}{c}\text { Relações com a Conjuração Baiana de } \\
1798\end{array}$ \\
\hline José Pires de Carvalho e Albuquerque ${ }^{523}$ & $\begin{array}{l}\text { Secretário de Estado e Governo do Brasil } \\
\text { e proprietário de escravos entregues à } \\
\text { justiça durante as investigações da } \\
\text { Conjuração Baiana de } 1798 \text {. }\end{array}$ \\
\hline Bernardino de Sena e Araújo $^{524}$ & $\begin{array}{l}\text { Tabelião e Escrivão do Público Judicial, } \\
\text { Juiz dos Órfãos e proprietário de escravos } \\
\text { entregues à justiça durante as } \\
\text { investigações da Conjuração Baiana de } \\
1798 \text {. }\end{array}$ \\
\hline Antônio Barbosa Oliveira ${ }^{525}$ & $\begin{array}{l}\text { Advogado dos Réus das devassas da } \\
\text { Conjuração Baiana de } 1798 .\end{array}$ \\
\hline Padre Francisco Agostinho Gomes ${ }^{526}$ & $\begin{array}{l}\text { Denunciado por um dos réus da } \\
\text { Conjuração Baiana de } 1798 \text { por fazer } \\
\text { jantar de carne em sexta-feira santa. } \\
\text { Sofreu devassa durante as investigações } \\
\text { do movimento. }\end{array}$ \\
\hline Jacinto Dias Damásio ${ }^{527}$ & $\begin{array}{l}\text { Testemunha nas devassas da Conjuração } \\
\text { Baiana de 1798, acusado de fazer jantar de } \\
\text { carne em sexta-feira santa, junto com o } \\
\text { padre Francisco Agostinho Gomes. }\end{array}$ \\
\hline Adriano de Araújo Braga ${ }^{528}$ & $\begin{array}{l}\text { Traficante de escravo e Administrador do } \\
\text { Celeiro Público da Bahia durante os anos } \\
\text { de 1796-1800. Defendeu José Pires de } \\
\text { Carvalho e Albuquerque para que ele }\end{array}$ \\
\hline
\end{tabular}

${ }^{523}$ ANTT, Conselho Geral do Santo Ofício, Tribunal do Santo Ofício, Diligências de Habilitação, Maço 40, Diligência 641.

${ }^{524}$ ANTT, Conselho Geral do Santo Ofício, Tribunal do Santo Ofício, Diligências de Habilitação, Maço 2, Diligência 23.

${ }^{525}$ ANTT, Conselho Geral do Santo Ofício, Tribunal do Santo Ofício, Diligências de Habilitação, Maço 191, Diligência 2860.

${ }^{526}$ ANTT, Conselho Geral do Santo Ofício, Tribunal do Santo Ofício, Diligências de Habilitação, Maço 1, Diligência 25.

${ }^{527}$ ANTT, Conselho Geral do Santo Ofício, Tribunal do Santo Ofício, Diligências de Habilitação, Maço 2, Diligência 26.

${ }_{528}$ ANTT, Conselho Geral do Santo Ofício, Tribunal do Santo Ofício, Diligências de Habilitação, Maço 1, Diligência 1. 


\begin{tabular}{|l|l|}
\hline & $\begin{array}{l}\text { continuasse a cobrar taxas altas das } \\
\text { embarcações que carregavam os grãos } \\
\text { para o abastecimento da capitania. }\end{array}$ \\
\hline Manoel Joaquim Álvares Ribeiro $^{529}$ & $\begin{array}{l}\text { Negociante e sócio no grupo que ofereceu } \\
1 \text { milhão de cruzados e mais donativos } \\
\text { anuais para a arrematação do contrato do } \\
\text { dízimo da capitania da Bahia no final do } \\
\text { século XVIII. }\end{array}$ \\
\hline Domingos José de Carvalho $^{530}$ & $\begin{array}{l}\text { Negociante e sócio no grupo que ofereceu } \\
1 \text { milhão de cruzados e mais donativos } \\
\text { anuais para a arrematação do contrato do } \\
\text { dízimo da capitania da Bahia no final do } \\
\text { século XVIII. }\end{array}$ \\
\hline
\end{tabular}

Considerando que entre o grupo de Familiares do Santo Ofício arrolados acima José Pires de Carvalho e Albuquerque, Bernardino de Sena e Araújo, Caetano Maurício Machado e Manoel José Vilella de Carvalho eram também habilitados na Ordem de Cristo $^{531}$, não parece restar dúvidas sobre o fato de que esses homens estavam contidos nas categorias sociais arroladas pelos autores dos boletins manuscritos. Importante nesse sentido é notar a opção dos autores dos boletins manuscritos em destacar a presença de Familiares do Santo Ofício entre os membros do "Partido da Liberdade", em um momento em que a Inquisição já não tinha o status que tivera nos períodos anteriores da colonização portuguesa.

Segundo Francisco Bethencourt, os Familiares do Santo Ofício eram os oficiais em maior quantidade e que ocupavam o grau mais baixo da estrutura organizacional da Inquisição portuguesa ${ }^{532}$. Para se habilitar como familiar, o candidato devia ser abastado

${ }^{529}$ ANTT, Conselho Geral do Santo Ofício, Tribunal do Santo Ofício, Diligências de Habilitação, Maço 87, Diligência 1646.

${ }^{530}$ ANTT, Conselho Geral do Santo Ofício, Tribunal do Santo Ofício, Diligências de Habilitação, Maço 33, Diligência 610.

${ }^{531}$ ANTT, Códice Habilitação da Ordem de Cristo: José Pires de Carvalho e Albuquerque, filho de outro do mesmo nome, e de D. Isabel Joaquina de Aragão. De 19 de maio de 1779. Habilitação da Ordem de Cristo. Letra J, Maço 49, número 5; Bernardino de Sena e Araújo. Habilitação da Ordem de Cristo, Letra B, Maço 9, número 1; Caetano Maurício Machado. Habilitação da Ordem de Cristo, Letra C, Maço 8, número 3; Manoel José Vilela de Carvalho. Habilitação da Ordem de Cristo, Letra M, Maço 37, número 8; Manoel José Vilela de Carvalho. Habilitação da Ordem de Cristo, Letra M, Maço 29, número 42.

${ }^{532}$ Francisco Bethencourt. História das Inquisições, Portugal, Espanha e Itália, Séculos XV-XIX. São Paulo: Cia das Letras, 2000. 
de bens, "viver limpamente", não ter ascendente condenado pelo Santo Ofício e principalmente "ser limpo de sangue". Os descendentes de judeus, mouros e mulatos não eram aceitos no quadro de agentes inquisitoriais, pois a distinção social oferecida pela familiatura estava ligada à perpetuação, por meio dos estatutos de limpeza de sangue, da fratura da ordem social portuguesa que separava, do lado positivo, os limpos de sangue (cristãos-velhos) e, do lado negativo, os de "sangue infecto" (sobretudo os descendentes de judeus). Nessa perspectiva, a familiatura funcionava como um atestado público de limpeza de sangue ${ }^{533}$.

A vasta presença desse tipo de agente na colônia até as duas primeiras décadas do século XIX demonstra como o uso social da Inquisição foi constante durante o funcionamento da instituição, exercendo um importante aparato nas lutas locais de poder $^{534}$. Muito provavelmente a presença da categoria "8 Familiares do Santo Ofício" indica uma estratégia política de os autores dos boletins reafirmarem a presença de homens dos setores privilegiados da sociedade baiana do final do século XVIII. Essa afirmação adquire complexidade se considerarmos que o número de testemunhas arroladas nas devassas de residência tiradas nos últimos anos do século XVIII coincide não apenas com alguns nomes da corporação dos enteados como também com os nomes e o número total da soma das categorias "Familiares do Santo Ofício" e "homens do comércio": 16.

Além disso, se considerarmos as demandas políticas e econômicas da corporação dos enteados nos últimos anos do século XVIII, descritas anteriormente, sobretudo as do Secretário de Estado e Governo do Brasil, José Pires de Carvalho e Albuquerque, pode-se afirmar com alguma tranquilidade que as demandas políticas e econômicas expressas nos boletins manuscritos contemplavam grupos sociais distintos que compunham o "Partido da Liberdade". No "Avizo ao Povo $N^{\circ}$ 6" afirmam os autores dos boletins manuscritos:

“[...] para o que faz que seja siente o Comércio desta Cidade, outrossim ordena que qualquer comissário, mercador, mascates, lavradores de mandiocas, fabricantes de açúcar,

\footnotetext{
533 Fernanda Olival. Rigor e interesses: os estatutos de limpeza de sangue em Portugal. Cadernos de Estudos Sefarditas, n.4, p.151-182, 2004. Sobre uma análise detida do processo de habilitação ao cargo de familiar, ler: Aldair Carlos Rodrigues. Sociedade e Inquisição em Minas colonial: os familiares do Santo Ofício (1711-1808). Dissertação de Mestrado, DH/FFLCH/USP, 2007.

${ }^{534}$ Cf. James E Wadsworth. Joaquim Marques de Araújo: o poder da Inquisição em Pernambuco no fim do período colonial. In: Maria Beatriz Nizza da Silva. (Org) De Cabral a Pedro I: Aspectos da colonização portuguesa no Brasil. Porto: Humberpto, 2001; Sonia A Siqueira. A inquisição portuguesa e a sociedade colonial. São Paulo: Ática, 1978. (Ensaios, 56).
} 
tabacos hajão de ter todo o direito soubre as suas fazendas com auxílio do Povo segundo o plano e boa ordem para que esse fim se tem pensado além do socorro de fora. Para o dito efeito se tomarão as medidas tudo a bem do Povo, principalmente aumento do Comércio e Lavradores: os taverneiros também serão contemplados na boa união "535.

Como se vê, as demandas econômicas contemplaram os setores médios e altos da sociedade soteropolitana da época, como, por exemplo, lavradores, taverneiros e, sobretudo, os fabricantes de açúcar e tabacos. Cumpre destacar que entre os membros da corporação dos enteados e os Familiares do Santo Ofício, José Pires de Carvalho e Albuquerque era proprietário de alguns engenhos e fazendas de tabaco, bem como Bernardino de Sena e Araújo, Francisco Vicente Viana, Caetano Maurício Machado, Manoel José Villela de Carvalho e Maria Francisca da Conceição e Aragão ${ }^{536}$, conforme a tabela abaixo:

\section{Relação dos Proprietários de engenhos da Capitania da Bahia, 1807.}

\begin{tabular}{|l|l|l|}
\hline \multicolumn{1}{|c|}{ Nome } & \multicolumn{1}{|c|}{ Proprietário } & \multicolumn{1}{c|}{ Localização } \\
\hline Madruga Cedo & Francisco Vicente Vianna & $\begin{array}{l}\text { Engenho situado à beira } \\
\text { mar, no distrito da Villa de } \\
\text { São Francisco do Sergipe } \\
\text { do Conde. }\end{array}$ \\
\hline Paramerim & Francisco Vicente Vianna & Idem \\
\hline Monte. & Francisco Vicente Vianna & $\begin{array}{l}\text { Distrito da Villa de São } \\
\text { Francisco do Conde, } \\
\text { distante quase hum quarto } \\
\text { de légoa do porto do mar. }\end{array}$ \\
\hline São Bernardo & Luiz Pereira Sodré & $\begin{array}{l}\text { Situado no Termo de } \\
\text { Jaguaripe à beira mar. }\end{array}$ \\
\hline Rosário & Luiz Pereira Sodré & $\begin{array}{l}\text { Situado no Termo da Villa } \\
\text { de Caxoeira. }\end{array}$ \\
\hline Camarogi & $\begin{array}{l}\text { D. Leonor Francisca Calmon } \\
\text { de Aragão }\end{array}$ & $\begin{array}{l}\text { Freguesia de São Pedro do } \\
\text { Rio Fundo. }\end{array}$ \\
\hline Maroim & $\begin{array}{l}\text { D. Anna Joaquina de São } \\
\text { José e Aragão }\end{array}$ & $\begin{array}{l}\text { Situado na freguesia de S. } \\
\text { Tiago do Igoape, no no } \\
\text { Termo da Villa de } \\
\text { Caxoeira. }\end{array}$ \\
\hline Maria & $\begin{array}{l}\text { Situado na freguesia de } \\
\text { Nossa Senhora do Ó, em } \\
\text { Paripe. }\end{array}$ \\
\hline
\end{tabular}

535 APUD. Kátia M. de Queirós Mattoso. Presença Francesa no Movimento Democrático Baiano de 1798. Salvador: Itapuã, 1969, pp. 151-152.

${ }^{536}$ APEB, Colonial, Matrículas dos Engenhos da Capitania da Bahia pelos Dízimos Reais, Administrados pela Junta da Real Fazenda, 1807, Livro 632. 


\begin{tabular}{|c|c|c|}
\hline Guaíba & $\begin{array}{lll}\text { Jozé Diogo } & \text { Gomes } & \text { Ferrão } \\
\text { Castel Branco } & & \end{array}$ & $\begin{array}{l}\text { Situado na freguesia da } \\
\text { Nossa Senhora do Monte, } \\
\text { termo da Villa de São } \\
\text { Francisco. }\end{array}$ \\
\hline Vera Cruz & $\begin{array}{l}\text { Jozé Diogo Gomes Ferrão } \\
\text { Castel Branco }\end{array}$ & $\begin{array}{l}\text { Situado na } r \text { mesma } \\
\text { freguesia acima, distante } \\
\text { do porto de embarque } \\
\text { perto de legoa. }\end{array}$ \\
\hline St. Anna da Pitanga & $\begin{array}{lll}\text { Jozé Diogo } & \text { Gomes } & \text { Ferrão } \\
\text { Castel Branco } & & \end{array}$ & $\begin{array}{l}\text { Situado na freguesia de St. } \\
\text { Anna do Catú, Termo da } \\
\text { Villa de S. Francisco, } \\
\text { distante } 6 \text { legoas do porto } \\
\text { de embarque. }\end{array}$ \\
\hline São Pedro & Francisco Borges de Barros & $\begin{array}{l}\text { Situado na Freguesia de } \mathrm{S} \text {. } \\
\text { Amaro da Purificação, } \\
\text { distante do porto de } \\
\text { embarque } 3 \text { legoas. }\end{array}$ \\
\hline Santa Cruz de Torres & Francisco Agostinho Gomes & $\begin{array}{l}\text { Situado à beira-mar, na } \\
\text { freguesia de Nossa } \\
\text { Senhora do Ó do Paripe, } \\
\text { Termo da Cidade de } \\
\text { Salvador. }\end{array}$ \\
\hline Guaíba do Bulcão & $\begin{array}{l}\text { Joaquim Ignácio de Siqueira } \\
\text { Bulcão, cunhado de José } \\
\text { Pires de Carvalho e } \\
\text { Albuquerque }\end{array}$ & $\begin{array}{l}\text { Situado à beira mar, no } \\
\text { Termo da Villa de S. } \\
\text { Francisco. }\end{array}$ \\
\hline Engenho D’Ágoa & $\begin{array}{l}\text { Joaquim Ignácio de Siqueira } \\
\text { Bulcão, cunhado de José } \\
\text { Pires de Carvalho e } \\
\text { Albuquerque }\end{array}$ & $\begin{array}{l}\text { Situado no } r \text { mesmo } \\
\text { Districto acima, distante } 1 / 4 \\
\text { de legoa do porto de } \\
\text { embarque. }\end{array}$ \\
\hline Engenho Novo & $\begin{array}{l}\text { Joaquim Ignácio de Siqueira } \\
\text { Bulcão }\end{array}$ & $\begin{array}{l}\text { Situado no mesmo Termo } \\
\text { acima. }\end{array}$ \\
\hline Cassarangongo & $\begin{array}{l}\text { Joaquim Ignácio de Siqueira } \\
\text { Bulcão, cunhado de José } \\
\text { Pires de Carvalho e } \\
\text { Albuquerque }\end{array}$ & $\begin{array}{l}\text { Situado no Termo da Villa } \\
\text { de S. Francisco, distante } \\
\text { huma legoa do porto de } \\
\text { embarque. }\end{array}$ \\
\hline Pacaracanga & $\begin{array}{l}\text { Desembargador Antônio } \\
\text { Feliciano de Sá Carneiro }\end{array}$ & $\begin{array}{l}\text { Situado à beira mar, na } \\
\text { Freguesia de Passé, Termo } \\
\text { da Cidade de Salvador. }\end{array}$ \\
\hline Nossa Senhora do Desterro & $\begin{array}{l}\text { Desembargador Antônio } \\
\text { Feliciano de Sá Carneiro }\end{array}$ & $\begin{array}{l}\text { Situado à beira mar, na } \\
\text { Freguesia de Passé, Termo } \\
\text { da Cidade de Salvador. }\end{array}$ \\
\hline Jacuipe do Brito & 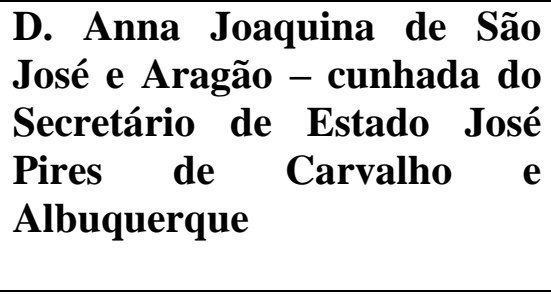 & $\begin{array}{l}\text { Situado na Freguesia de S. } \\
\text { Pedro do Rio Fundo, } \\
\text { Termo da Villa de S. } \\
\text { Amaro da Purificação, } \\
\text { distante } 3 \text { legoas do porto } \\
\text { de embarque. }\end{array}$ \\
\hline Cazumba & $\begin{array}{lrrr}\text { D. Maria } & \text { Francisca } & \text { da } \\
\text { Conceição } & \text { e } & \text { Aragão } & \text { - }\end{array}$ & $\begin{array}{l}\text { Situado no Termo da Villa } \\
\text { de S. Amaro, distante } 2\end{array}$ \\
\hline
\end{tabular}




\begin{tabular}{|c|c|c|}
\hline & $\begin{array}{llcl}\text { cunhada } & \text { do } & \text { Secretário } & \text { de } \\
\text { Estado } & \text { José } \quad \text { Pires } & \text { de } \\
\text { Carvalho e Albuquerque } & \end{array}$ & $\begin{array}{l}\text { legoas do porto de } \\
\text { embarque. }\end{array}$ \\
\hline Mataripe & $\begin{array}{l}\text { Antônio Moniz de Souza } \\
\text { Barreto e Aragão }\end{array}$ & $\begin{array}{l}\text { Situado à beira mar, na } \\
\text { Villa de S. Francisco de } \\
\text { Sergipe do Conde. }\end{array}$ \\
\hline Santo Estevão & $\begin{array}{l}\text { Antônio Moniz de } \\
\text { Barreto e Aragão }\end{array}$ & $\begin{array}{l}\text { Situado à beira mar, na } \\
\text { Villa de S. Francisco de } \\
\text { Sergipe do Conde. }\end{array}$ \\
\hline Nossa Senhora do Desterro & $\begin{array}{l}\text { Antônio Moniz de Souza } \\
\text { Barreto e Aragão }\end{array}$ & $\begin{array}{l}\text { Situado à beira mar, na } \\
\text { Villa de S. Francisco de } \\
\text { Sergipe do Conde. }\end{array}$ \\
\hline Papagaio & $\begin{array}{l}\text { Antônio Moniz de } \quad \text { Souza } \\
\text { Barreto e Aragão }\end{array}$ & $\begin{array}{l}\text { Situado no Termo da Villa } \\
\text { de Sto. Amaro, Freguesia } \\
\text { de Nossa Senhora da } \\
\text { Purificação, distante do } \\
\text { porto de mar } 1 / 2 \text { legoa. }\end{array}$ \\
\hline Engenho Velho & $\begin{array}{l}\text { D. Joaquina Maria Borges de } \\
\text { S. Anna }\end{array}$ & $\begin{array}{l}\text { Situado no Termo da Villa } \\
\text { de S. Amaro da } \\
\text { Purificação, distante do } \\
\text { porto de mar legoa e meia. }\end{array}$ \\
\hline Grama & $\begin{array}{l}\text { D. Francisca Maria da } \\
\text { Conceição }\end{array}$ & $\begin{array}{l}\text { Situado no districto da } \\
\text { Villa de S. Francisco, } \\
\text { distante do porto de mar } \\
\text { legoa e meia. }\end{array}$ \\
\hline D. João & $\begin{array}{l}\text { D. Mariana Angélica de Araújo } \\
\text { e Azevedo }\end{array}$ & $\begin{array}{l}\text { Situado à beira mar, no } \\
\text { districto da Villa de S. } \\
\text { Francisco. }\end{array}$ \\
\hline Araticum & $\begin{array}{l}\text { D. Mariana Angélica de Araújo } \\
\text { e Azevedo }\end{array}$ & $\begin{array}{l}\text { Situado no Districto da } \\
\text { Villa de S. Francisco, } \\
\text { distante do porto de mar } 6 \\
\text { legoas. }\end{array}$ \\
\hline $\begin{array}{l}\text { Nossa Senhora da Luz da } \\
\text { Passagem }\end{array}$ & $\begin{array}{l}\text { Antônio Joaquim Pires de } \\
\text { Carvalho e Albuquerque - } \\
\text { filho de José Pires de } \\
\text { Carvalho e Albuquerque }\end{array}$ & \begin{tabular}{l}
\multicolumn{3}{l}{ Situado no Termo da Villa } \\
de S. Amaro da \\
Purificação, distante do \\
porto de mar meia legoa.
\end{tabular} \\
\hline Santa Anna & $\begin{array}{l}\text { Antônio Joaquim Pires de } \\
\text { Carvalho e Albuquerque - } \\
\text { filho de José Pires de } \\
\text { Carvalho e Albuquerque }\end{array}$ & $\begin{array}{l}\text { Situado no } \\
\text { de Sermo da Villa } \\
\text { Purificação, distante do } \\
\text { Porto de Mar } 3 / 4 \text { de legoas. }\end{array}$ \\
\hline Jacuipe & $\begin{array}{l}\text { D. Francisco de Bitancourt e } \\
\text { Aragão }\end{array}$ & $\begin{array}{l}\text { Situado no Termo d Villa } \\
\text { de S. Francisco, distante } \\
\text { do porto de mar } 4 \text { legoas. }\end{array}$ \\
\hline Paciência & $\begin{array}{l}\text { D. Francisco Bitancourt e } \\
\text { Aragão }\end{array}$ & $\begin{array}{l}\text { Situado no Termo da Villa } \\
\text { de S. Francisco, distante } \\
\text { do porto de mar } 4 \text { legoas. }\end{array}$ \\
\hline Canabraba & $\begin{array}{l}\text { D. Francisco Bitancourt e } \\
\text { Aragão }\end{array}$ & $\begin{array}{l}\text { Situado no Termo da Villa } \\
\text { de S. Francisco, distante } \\
\text { do porto de mar } 5 \text { legoas e } \\
\text { meia. }\end{array}$ \\
\hline
\end{tabular}




\begin{tabular}{|c|c|c|}
\hline Mombaça & $\begin{array}{l}\text { D. Caetana Joaquina de } \\
\text { Fonseca Machado }- \text { esposa } \\
\text { de Caetano } \text { Maurício } \\
\text { Machado }\end{array}$ & $\begin{array}{l}\text { Situado no Termo da Villa } \\
\text { de S. Francisco, distante } \\
\text { do porto de mar } 4 \text { legoas. }\end{array}$ \\
\hline Campo & $\begin{array}{l}\text { D. Caetana Joaquina de } \\
\text { Fonseca Machado- esposa de } \\
\text { Caetano Maurício Machado }\end{array}$ & $\begin{array}{l}\text { Situado no Termo da Villa } \\
\text { de S. Francisco, distante } \\
\text { do porto de mar } 5 \text { legoas. }\end{array}$ \\
\hline Guariba & Antônio Borges de Barros & \begin{tabular}{lr}
\multicolumn{3}{l}{ Situado no } & Termo da Villa \\
de S. Amaro da & de \\
Purificação, distante & do \\
porto de mar 6 legoas.
\end{tabular} \\
\hline Cobé & D. Francisca da Rocha Pitta & $\begin{array}{l}\text { Situado no Termo da } \\
\text { Cidade de Salvador, } \\
\text { distante do porto de mar } 2 \\
\text { legoas. }\end{array}$ \\
\hline S. João do Mathoim & $\begin{array}{l}\text { D. Leonor Francisca Calmon } \\
\text { de Aragão }\end{array}$ & $\begin{array}{l}\text { Situado à beira mar, no } \\
\text { Termo da Villa de S. } \\
\text { Francisco. }\end{array}$ \\
\hline Petinga & $\begin{array}{l}\text { D. Anna Custódia de Jesus e } \\
\text { Aragão }\end{array}$ & $\begin{array}{l}\text { Situado à beira mar, na } \\
\text { Freguesia de Passe, Termo } \\
\text { da Cidade de Salvador. }\end{array}$ \\
\hline Brotas & $\begin{array}{l}\text { D. Anna Maria Francisca } \\
\text { Romana de Albuquerque }\end{array}$ & 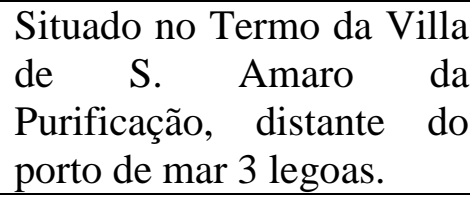 \\
\hline Nossa Senhora da Piedade & $\begin{array}{l}\text { D. Brites } \text { Francisca } \\
\text { Cavalcante e Albuquerque - } \\
\text { prima de José Pires de } \\
\text { Carvalho e Albuquerque }\end{array}$ & \begin{tabular}{l}
\multicolumn{3}{l}{ Situado no Termo da Villa } \\
de S. Amaro da \\
Purificação, distante \\
porto do mar 2 legoas.
\end{tabular} \\
\hline Rosário & $\begin{array}{l}\text { D. Anna Maria de São José e } \\
\text { Aragão }- \text { esposa de José } \\
\text { Pires de Carvalho e e } \\
\text { Albuquerque }\end{array}$ & $\begin{array}{l}\text { Situado à beira mar no } \\
\text { districto da Villa de } \mathrm{S} \text {. } \\
\text { Amaro da Purificação. }\end{array}$ \\
\hline São Miguel & $\begin{array}{l}\text { D. Anna Maria de São José e } \\
\text { Aragão }- \text { esposa de José } \\
\text { Pires de Carvalho e e } \\
\text { Albuquerque }\end{array}$ & $\begin{array}{l}\text { Situado à beira mar no } \\
\text { districto da Villa de } \mathrm{S} . \\
\text { Amaro da Purificação. }\end{array}$ \\
\hline Nazareth & $\begin{array}{l}\text { D. Anna Maria de São José e } \\
\text { Aragão }- \text { esposa de José } \\
\text { Pires de Carvalho e e } \\
\text { Albuquerque }\end{array}$ & $\begin{array}{l}\text { Situado à beira mar no } \\
\text { districto da Villa de } \mathrm{S} . \\
\text { Amaro da Purificação. }\end{array}$ \\
\hline Quissassá & $\begin{array}{l}\text { Padre Antônio Pires de } \\
\text { Carvalho e Albuquerque - } \\
\text { irmão de José Pires de } \\
\text { Carvalho e Albuquerque }\end{array}$ & $\begin{array}{l}\text { Situado no Termo da Villa } \\
\text { de Jagoaripe, distante do } \\
\text { porto de mar meia legoa. }\end{array}$ \\
\hline Buraco & $\begin{array}{lll}\text { Francisco } & \text { Furtado } & \text { de } \\
\text { Mendonça } & & \end{array}$ & $\begin{array}{l}\text { Situado na Comarca de } \\
\text { Sergipe Del Rey, distante } \\
\text { do porto de mar } 3 \text { legoas. }\end{array}$ \\
\hline Caboassú & Antônio Borges de Barros & $\begin{array}{l}\text { Situado no Termo da Villa } \\
\text { de } \quad \text { S. Amaro da }\end{array}$ \\
\hline
\end{tabular}




\begin{tabular}{|c|c|c|}
\hline & & $\begin{array}{l}\text { Purificação, distante do } \\
\text { porto de mar huma legoa. }\end{array}$ \\
\hline São José do Egipto & Salvador Borges de Barros & \begin{tabular}{l}
\multicolumn{3}{l}{ Situado no termo da Villa } \\
de S. Amaro da \\
Purificação, distante \\
porto de embarque \\
legoas.
\end{tabular} \\
\hline São Carlos & $\begin{array}{l}\text { Desembargador Luís Thomás } \\
\text { Navarro de Campos }\end{array}$ & $\begin{array}{l}\text { Situado à beira mar no } \\
\text { Rosário da Villa da } \\
\text { Caxoeira. }\end{array}$ \\
\hline Maroim de Baixo & Manoel Roiz de Figueiredo & $\begin{array}{l}\text { Situado na Cotenguiba, } \\
\text { distante do porto de } \\
\text { embarque } 3 \text { legoas. }\end{array}$ \\
\hline Tanque & $\begin{array}{l}\text { Joaquim Egas Moniz de Souza } \\
\text { Barreto e Aragão }\end{array}$ & $\begin{array}{l}\text { Situado no Termo da Villa } \\
\text { de S. Francisco, distante } \\
\text { do porto de embarque } \\
\text { huma legoa. }\end{array}$ \\
\hline Pillar & $\begin{array}{l}\text { Desembargador Antônio José } \\
\text { Ozório de Pina Leitão }\end{array}$ & $\begin{array}{l}\text { Situado à beira mar no } \\
\text { Termo da Villa de } \mathrm{S} . \\
\text { Amaro da Purificação. }\end{array}$ \\
\hline Campina-Grande & João Ladislao de Figueiredo & $\begin{array}{l}\text { Situado na Freguesia das } \\
\text { Brotas, Termo da Cidade } \\
\text { de Salvador, distante do } \\
\text { porto de embarque meia } \\
\text { legoa. }\end{array}$ \\
\hline Solidão & $\begin{array}{llll}\text { Cypriano José } & \text { Barata de } \\
\text { Almeida } & & & \end{array}$ & $\begin{array}{l}\text { Situado na Villa Abrantes, } \\
\text { termo da Cidade de } \\
\text { Salvador, distante do porto } \\
\text { de embarque } 4 \text { legoas. }\end{array}$ \\
\hline S. Antonio da Boa Sorte & José Joaquim de S. Anna & $\begin{array}{l}\text { Situado no Termo da Villa } \\
\text { de Trambupe, distante do } \\
\text { porto de embarque } 12 \\
\text { legoas. }\end{array}$ \\
\hline S. Anna do Barro & $\begin{array}{l}\text { Barão da Torre - filho de } \\
\text { José Pires de Carvalho e } \\
\text { Albuquerque }\end{array}$ & $\begin{array}{l}\text { Situado na Freguesia do } \\
\text { Assú da Torre, distante do } \\
\text { porto de Jacaracanga } 15 \\
\text { legoas. }\end{array}$ \\
\hline Paciência & Antônio Borges de Barros & $\begin{array}{l}\text { Situado na Freguesia de S. } \\
\text { Pedro do Rio Fundo, } \\
\text { Termo da Villa de S. } \\
\text { Amaro da Purificação, } \\
\text { distante do porto do mar } 3 \\
\text { legoas. }\end{array}$ \\
\hline S. Antonio das Trairas & $\begin{array}{l}\text { Desembargador Joaquim José } \\
\text { da Silva Azevedo }\end{array}$ & $\begin{array}{l}\text { Situado no Termo da Villa } \\
\text { de Maragogipe, distante do } \\
\text { porto de mar huma legoa. }\end{array}$ \\
\hline Pericuara & $\begin{array}{l}\text { D. Maria Joaquina } \\
\text { Betencourt e Aragão }\end{array}$ & $\begin{array}{l}\text { Situado na Freguesia de S. } \\
\text { Gonçalo, Termo da Villa } \\
\text { de S. Francisco do Sergipe } \\
\text { do Conde. }\end{array}$ \\
\hline
\end{tabular}




\begin{tabular}{|c|c|c|}
\hline Bom Gosto & $\begin{array}{l}\text { Barão de Maragogipe - filho } \\
\text { de José Pires de Carvalho e } \\
\text { Albuquerque }\end{array}$ & $\begin{array}{l}\text { Situado no Termo da Villa } \\
\text { de S. Francisco do Sergipe } \\
\text { do Conde, distante do } \\
\text { porto de embarque } 4 \\
\text { legoas. }\end{array}$ \\
\hline Boa Esperança & $\begin{array}{l}\text { D. Maria da Silva de São José } \\
\text { Boa Esperança }\end{array}$ & $\begin{array}{lcr}\text { Situado na beira } & \text { de } \\
\text { Tubaúma } & (?) & \text { no } \\
\text { Gameleiro, distante } & \text { do } \\
\text { porto de } & \text { embarque } & 6 \\
\text { legoas. } & & \end{array}$ \\
\hline Querente & $\begin{array}{l}\text { Joaquim Ignácio de Aragão } \\
\text { Bulcão - cunhado de José } \\
\text { Pires de Carvalho e } \\
\text { Albuquerque }\end{array}$ & $\begin{array}{l}\text { Situado na Freguesia de N. } \\
\text { Senhora da Purificação de } \\
\text { Passé, distante do porto de } \\
\text { embarque huma legoa. }\end{array}$ \\
\hline Santo Antonio do Pará & $\begin{array}{l}\text { Antônio Augusto Pires de } \\
\text { Carvalho e Albuquerque - } \\
\text { filho de José Pires de } \\
\text { Carvalho e Albuquerque }\end{array}$ & $\begin{array}{l}\text { Situado na Freguesia de S. } \\
\text { Amaro da Purificação, } \\
\text { distante do porto de } \\
\text { embarque } 1 / 2 \text { legoa. }\end{array}$ \\
\hline $\begin{array}{l}\text { N. Senhora do Pillar do } \\
\text { Traripe }\end{array}$ & $\begin{array}{l}\text { Desembargador Manoel dos } \\
\text { Santos Meirelles Vasques }\end{array}$ & $\begin{array}{l}\text { Situado na Freguesia de S. } \\
\text { Gonçalo, Termo da Villa } \\
\text { de S. Francisco do Sergipe } \\
\text { do Conde, distante do } \\
\text { porto de embarque huma } \\
\text { legoa. }\end{array}$ \\
\hline Itapoan & $\begin{array}{l}\text { Coronel Francisco José de } \\
\text { Mattos Ferreira Lucena }\end{array}$ & $\begin{array}{l}\text { Situado na Frequesia de S. } \\
\text { Amaro d'Ipitanga, distante } \\
\text { do porto de embarque } \\
\text { huma legoa }\end{array}$ \\
\hline Itapitingui & $\begin{array}{l}\text { Ignácio Pires de Carvalho e } \\
\text { Albuquerque - primo de José } \\
\text { Pires de Carvalho e } \\
\text { Albuquerque }\end{array}$ & $\begin{array}{l}\text { Situado na Freguesia de } \mathrm{N} \text {. } \\
\text { Senhora da Purificação de } \\
\text { S. Amaro, distante do } \\
\text { porto de embarque } 2 \text { e } 1 / 2 \\
\text { legoas. }\end{array}$ \\
\hline Glória & $\begin{array}{l}\text { Desembargador Pedro Moniz } \\
\text { Barreto de Aragão }\end{array}$ & $\begin{array}{l}\text { Situado na Freguesia de S. } \\
\text { Amaro da Purificação, } \\
\text { distante do porto de } \\
\text { embarque huma legoa. }\end{array}$ \\
\hline
\end{tabular}

APEB, Colonial, Matrículas dos Engenhos da Capitania da Bahia pelos Dízimos Reais, Administrados pela Junta da Real Fazenda, 1807, Livro 632.

Para além da constatação de que o Secretário de Estado e Governo do Brasil e seus parentes eram os maiores proprietários de engenhos da capitania da Bahia no início do século XIX - por ter herdado o morgado da Casa da Torre - cumpre destacar que entre os senhores de engenhos arrolados em 1807, Francisco Agostinho Gomes ${ }^{537}$ e

537 AHU_CU_BAÍA, docs. 19.117-19.178. “Auto da devaça a que se procedeu o Ouvidor Geral do Crime, doutor Manuel de Magalhães Pinto de Avellar e Barbedo, para averiguação dos factos de que era acusado o padre Francisco Agostinho Gomes". "Devaça a que se procedeu em consequência da acussação feita ao padre Francisco de Agostinho Gomes de ter dado um jantar de carne em sexta-feira 
Cipriano José Barata ${ }^{538}$ foram implicados nas devassas da Conjuração Baiana de 1798. O Coronel Francisco José de Mattos Ferreira e Lucena era irmão do Capitão Antônio José de Mattos Ferreira e Lucena, importante testemunha contra os réus do movimento ${ }^{539}$.

Seja como for, a afirmação de que os boletins manuscritos contemplam as demandas políticas e econômicas de setores médios e altos da sociedade soteropolitana da época, que compunham o "Partido da Liberdade", é definitivamente corroborada pelo principal boletim manuscrito intitulado "Aviso ao Clero e ao Povo Bahinense Indouto $N^{o}$ 9”. Afirmam os autores que segundo os juramentos celebrados por 392 “Digníssimos Deputados Reprezentantes da Nação” em consulta individual de 284 "Entes que adoptão a total Liberdade Nacional; contida no geral receptáculo" de 676 homens, faz saber:

"que se axão as medidas tomadas para o socorro Estrangeiro, e progresso do Comércio de Açúcar, Tabaco e pau brazil e todos os mais gêneros de negocio e mais viveres; com tanto que aqui virão todos os Estrangeiros tendo porto aberto, mormente a Nação Franceza [...] quer o Povo que todos os Membros militares de Linha, milícias e ordenanças; homens brancos, pardos e pretos, concorrão para a Liberdade Popular; manda o Povo que cada hum soldado perceba de soldo dous tustoens cada dia, além de suas vantagens que serão relevantes ${ }^{, 540}$.

As informações do boletim $\mathrm{N}^{\circ} 9$ sugerem uma sofisticada estratégia de aliança política programática entre os membros do "Partido da Liberdade", que contemplavam tanto as demandas dos milicianos, com 200 soldos diários, quanto as demandas dos "homens do comércio" e "homens graduados em postos e cargos" com o livre comércio com todos os estrangeiros, sobretudo com a Nação Francesa - projetos que na base eram inconciliáveis na medida em que a isonomia dos critérios de ascensão aos postos militares para homens brancos, pardos, pretos e mulatos eram incompatíveis com os pressupostos tidos por necessários para a manutenção das clivagens sociais no Antigo

da Paixão". A devassa está integralmente publicada, por Braz do Amaral, na obra de Inácio Accioli. Cf. Accioli, op. cit., vol. III, pp. 140-150. Os documentos originais estão em Lisboa, no Arquivo Histórico Ultramarino, no códice Caixas da Bahia, doc. 20.807. A atuação do padre Francisco Agostinho Gomes na Conjuração Baiana de 1798 será objeto de análise no próximo capítulo.

${ }_{538}$ ADCA, Vol II, pp. 705-708: “Careação de Antônio Simoens da Cunha, homem pardo livre, com Lucas Dantas de Amorim Torres, Manuel Faustino dos Santos Lira, tão bem pardos, e Cipriano Jozé Barata branco, prezos nas cadêas desta Relação".

${ }^{539}$ ADCA, Vol. I, pp. 40-70.

${ }^{540}$ APUD Kátia M. de Queirós Mattoso, Presença Francesa no Movimento Democrático Baiano, op.cit., pp. 155-156. 
Regime, como, de fato, era o principal objetivo dos homens da corporação dos enteados. Além disso, a miragem de liberdade do comércio também era incompatível com a agenda política da corporação dos enteados e com os objetivos do grupo de negociantes soteropolitanos que arremataram o contrato do dízimo por 1 milhão de cruzados e mais donativos anuais, pois o fim do pacto colonial significaria, no limite, o fim dos privilégios políticos e econômicos desses dois grupos.

Os inconciliáveis projetos políticos e econômicos dos médios e altos setores contemplados nos boletins manuscritos demonstram que, se por um lado, os altos setores objetivavam a conservação das regras do pacto colonial para a manutenção de seus poderes políticos e econômicos na capitania da Bahia, por outro lado, a agenda dos médios setores representou a avant garde do movimento, à medida que a aliança política com setores privilegiados e suas demandas, como a isonomia no critério de ascensão aos cargos militares, eram contrapostas aos pressupostos tidos por necessários para a manutenção do pacto e do vínculo colonial, que privilegiavam alguns setores e legitimavam as desigualdades.

Não se trata aqui de afirmar que a aliança política inconciliável entre os setores médios e altos da sociedade baiana de 1798 significou "a busca de integração do conjunto da população, por cima das diferenças de riqueza, privilégios, origem e cor, em torno de um projeto de luta política", representando "a emergência de um grave risco para o projeto reformista ao introduzir entre o elenco de alternativas para a solução da crise a extinção pura e simples das relações de subordinação "541. Trata-se, ao contrário, de afirmar que a crise do sistema se manifestará na contradição em termos dos projetos políticos explicitados nos boletins manuscritos, nos quais os setores médios almejavam mudanças e os setores dominantes contrapunham-se às reformas de $\mathrm{d}$. Rodrigo de Sousa Coutinho e, ao que tudo indica, elaboraram demandas próprias em uma primeira fase da Conjuração Baiana de 1798 com o objetivo de manterem-se como setor dominante.

Essa afirmação adquire complexidade se considerarmos que após a Independência das Treze Colônias (1776) e da Revolução Francesa, deflagrada em 1789, no horizonte de expectativas da coroa portuguesa pairava o medo de duas principais questões presentes no Aviso $N^{\circ}$ 9: o livre comércio, especialmente com a Nação Francesa, representando o fim do pacto colonial e a efetiva ameaça de uma

\footnotetext{
${ }^{541}$ Cf. István Jancsó. Na Bahia contra o Império: história do ensaio de sedição de 1798. São Paulo: Hucitec, 1996, p. 206.
} 
revolução como à época ainda estava em curso na França ${ }^{542}$. Nesse sentido, a sofisticada estratégia programática entre os membros do "Partido da Liberdade", envolvendo apenas setores médios e altos da sociedade soteropolitana da época, soube capitalizar os medos no horizonte de expectativa da coroa portuguesa para empreender uma negociação apenas com os setores altos durante o curso das investigações, cujo resultado, como se terá oportunidade de demonstrar, foi definitivamente dada pelo centro, uma vez que a manutenção do domínio colonial português na América passou pela opção de a coroa portuguesa continuar governando a conflitualidade no interior dos setores dominantes.

Digno de nota é o fato de que os cativos não aparecem entre as categorias arroladas pelo Aviso $\mathrm{N}^{\circ} 1$, de sorte que a informação presente no Aviso $\mathrm{N}^{\circ} 9$ : $\underline{\text { no que }}$ respeita a inutilidade da escravidão do mesmo povo tão sagrado e Digno de ser livre $^{, 543}$, refere-se ao fim do domínio português no Brasil e não à liberdade dos escravos. A esse respeito, os relatos dos contemporâneos do evento são paradigmáticos, pois tanto para o professor régio Luís dos Santos Vilhena como para o provedor da Casa da Moeda José Venâncio de Seixas, a participação dos cativos aparece como uma possibilidade a ser considerada para no futuro ser evitada - pois caso ocorresse de fato uma revolta com a presença dos cativos, segundo os relatos, efetivamente colocaria em risco a legitimidade das desigualdades e o vínculo colonial. Para esses contemporâneos, ao contrário, a Conjuração Baiana de 1798 relacionou-se à iniquidade do poder local e aos desmandos da corporação dos enteados constantemente denunciadas por Vilhena ${ }^{544}$.

Se considerarmos que os escravos presos no Segredo da Relação durante as investigações da Conjuração Baiana de 1798 foram entregues por seus donos, membros da corporação dos enteados, Kátia Mattoso acerta ao analisar o alcance dos argumentos dos boletins manuscritos, afirmando que:

"se, por um lado, os revoltosos queriam sensibilizar a maior parte do público baiano com a miragem de liberdade econômica, por outro lado, procuraram também mostrar que uma eventual aquiescência a seu projeto político não contribuiria para o abalo das estruturas profundas da sociedade ${ }^{, 545}$.

\footnotetext{
${ }^{542}$ Cf. Fernando Antônio Novais, Brasil e Portugal na Crise do Antigo Sistema Colonial, op.cit. ${ }^{543}$ Idem. Grifo meu.

${ }^{544}$ Cf. Patrícia Valim. Da Sedição dos Mulatos à Conjuração Baiana de 1798: a construção de uma memória histórica. Dissertação de Mestrado/DH/FFLCH/USP, 2007. Ler, especialmente, o capítulo 2. ${ }^{545}$ Cf. Kátia M. de Queirós Mattoso, Bahia, 1798, op.cit., pp. 327-328.
} 
Com efeito, não parece exagerada a afirmação de que a coroa portuguesa rapidamente percebeu que a presença de pessoas dos setores privilegiados da sociedade baiana da época não era uma miragem dos autores dos boletins manuscritos nem uma estratégia dos setores médios e baixos para convencer o "Povo Indouto" a participar do levante que instituiria a "Republica Bahinense". A análise das categorias arroladas que seguiam o "Partido da Liberdade" demonstra que delas estão ausente apenas os cativos e não "os dois extremos da hierarquia social soteropolitana", como afirmou Kátia Mattoso $^{546}$, que motivou a historiografia que versou sobre o tema, durante os séculos XIX e XX, a reafirmá-lo como um levante circunscrito às categorias médias e baixas, essencialmente compostas por homens livres e libertos, brancos e mulatos ${ }^{547}$.

No entanto, se a ausência dos cativos no levante não chegou a representar efetiva ameaça à ordem estabelecida, situação bastante diversa ocorreu em relação à participação dos setores altos e o posicionamento político e diplomático dos partícipes do "Partido da Liberdade". A começar pelo explícito ataque a d. João VI:

"O vos homens Cidadaons, o vos Povos curvados $e$ abandonados pelo Rei, pelos seus dispotismos, pelos seus ministros ... $O$ vos Povo que nascesteis para sereis livres $e$ para gozares dos bons efeitos da Liberdade, o vos Povos que viveis flagelados com o pleno poder do Indigno coroado esse mesmo rei que vos creasteis; esse mesmo rei tirano he quem se firma no trono para vos veixar, para vos roubar e para vos maltratar $^{548}$.

Assim, os "Entes do Partido da Liberdade" questionaram a legitimidade da regência de d. João VI, que só foi oficialmente reconhecida no final de 1799, pois desde que diagnosticada a senilidade da rainha, em 1792, a opinião dos quadros da política metropolitana não era hegemônica a esse respeito ${ }^{549}$. Os autores dos boletins manuscritos, no entanto, foram além, mostrando-se contrários à tradicional posição de neutralidade da diplomacia portuguesa nos conflitos entre as potências europeias, especialmente a França e a Inglaterra. Explicitaram seu alinhamento político na aliança entre Castela e França e escolheram a França metropolitana como a principal nação que

\footnotetext{
${ }^{546}$ Cf. Idem, p. 324.

${ }^{547}$ Cf. Patrícia Valim. Da Sedição dos Mulatos à Conjuração Baiana de 1798, op.cit.

548 APUD. Kátia M. de Queirós Mattoso. Presença Francesa no Movimento Democrático Baiano de 1798. Salvador: Itapuã, 1969, p. 149, et. Seq. Grifo meu.

${ }^{549}$ Ler: Jorge Pedreira \& Fernando Dores Costa. D. João VI, O Clemente. Coleção Reis de Portugal. Lisboa: Círculo de Leitores, 2009. Especialmente o Capítulo 2 "Uma regência inesperada (1789-1799)", pp. 59-82.
} 
encontraria porto aberto para o livre comércio com a futura "República Bahinense" Parece inegável que o que estava em causa nessas agendas políticas dos autores dos boletins manuscritos era a fragilidade externa da monarquia portuguesa em relação às demais potências europeias, cujas consequências interferiam efetivamente nos planos da corporação dos enteados.

Em 27 de outubro de 1797, José Venâncio de Seixas, Provedor da Casa da Moeda em Salvador e Provedor da Alfândega - nomeado em 1799 -, escreveu um plano para d. Rodrigo de Sousa Coutinho, com o objetivo de "aumentar as rendas reaes da Capitania da Bahia”. Para José Venâncio de Seixas, a situação mudou em 1796, desde que principiaram as construções das fragatas, expedindo-se ordem pelo Real Erário à Junta da Fazenda para que se abrisse um empréstimo às novas despesas e consignações para Lisboa, fazendo com que sua Real Fazenda contraísse dívidas que antes não tinha.

$\mathrm{O}$ aumento das rendas reais face às novas despesas com o Arsenal da Marinha era de fato muito importante para a coroa portuguesa, pois apesar dos tratados de paz assinados com a Espanha e com a França, no final do século XVIII, a situação ficava cada vez mais complicada. Em 23 de março de 1797, D. Rodrigo de Sousa Coutinho enviou uma carta ao governador da capitania da Bahia, comunicando sobre a má fé dos espanhóis em desrespeitar o Tratado de Limites assinado em 1779, na região do Rio da Prata e nos rios da capitania do Mato Grosso. O Ministro solicitou que d. Fernando entrasse em acordo com o governador de São Paulo, Antônio Manuel de Melo Castro e Mendonça, e com Sebastião Xavier da Veiga, governador do Rio Grande, para que juntos pudessem evitar toda a decisão contrária aos interesses da Coroa Portuguesa. Caso houvesse necessidade, no entanto, os governadores deveriam se preparar para "huma Guerra funda, e tal que não só ponha hum decidido obstáculo a todo e qualquer ulterior progresso aos domínios de S. M. "

A ameaça sobre as invasões estrangeiras e a importância do Arsenal da Marinha nessa conjuntura também foi atestada na "Informaçam sobre a Bahia de Todos os Santos”, escrita por d. Miguel Antônio de Mello, Conde de Murça, governador de Angola (1797-1802), enviada a d. Rodrigo de Sousa Coutinho. Após constatar a precariedade das tropas e da defesa da costa da Bahia para o caso de um ataque estrangeiro, d. Miguel lembrou d. Rodrigo que o dinheiro que a coroa portuguesa tomou

\footnotetext{
${ }^{550}$ Cf. Kátia M. de Queirós Mattoso, op.cit. Ler, especialmente, o Aviso n ${ }^{\mathrm{o}} 3$ e Aviso ao Clero e ao Povo Bahinense Indouto, nº 9 , pp. 149-157.

${ }^{551}$ BN, Sessão de Manuscritos, II, 31, 2, 20, nº 9
} 
a crédito no Rio de Janeiro e na Bahia para aumentar a frota da marinha real, não cobria as despesas que Portugal contraiu para preservar seus territórios das efetivas ameaças de invasões estrangeiras ${ }^{552}$.

Jeanine Potelet nos mostra que durante o período revolucionário do Diretório e do Consulado Francês, de 1796-1800, foram protocolados oito projetos de expedição e ataques da marinha francesa à costa brasileira: um em 1796; um em 1797; três em 1799; e dois em 1800, com objetivo explícito de ruinar o comércio inglês na costa brasileira $^{553}$. Em 10 de abril de 1796, por exemplo, o projeto de expedição à costa brasileira do Tenente Vaisseau Polony, endereçado ao Vice-Almirante Truguet, Ministro da Marinha e das colônias francesas, propôs interceptar as embarcações inglesas e portuguesas em dois momentos: primeiro, na Ilha da Madeira; depois, entre Pernambuco e a Amazônia ${ }^{554}$, capitanias próximas à Guiana Francesa, cuja capital foi tomada por Portugal em $1808^{555}$.

A questão que preocupava d. Rodrigo de Sousa Coutinho era que em tempos de paz com a França, após o tratado de 1797, o interesse dos franceses na fronteira com a Guiana Francesa eram os estabelecimentos que poderiam servir, a um só tempo, como entreposto para o comércio clandestino e destacamento para o abastecimento das tropas. Não parece ser por outra razão que entre 1797 e 1800, foram relatados 12 episódios de ataques de corsários franceses às embarcações portuguesas na costa entre Pernambuco e Amazônia $^{556}$.

O principal plano apresentado ao Diretório Francês, no entanto, tinha por objetivo invadir a principal capitania do Império Português: a Bahia. Em 7 frutidor do ano V (24 de agosto de 1797), depois de sua estada em Salvador no mês de dezembro de 1796, o capitão e Chefe de Divisão das Armadas Navais Francesas, Antoine René Larcher (1740-1808) apresentou um projeto ao Diretório com a solicitação de que a França revolucionária realizasse uma intervenção militar e política na Bahia. Francisco

\footnotetext{
${ }^{552}$ BN, Sessão de Manuscritos, I-31, 21, 023, docs. 1 e 2. Esse documento está integralmente transcrito no Livro de Registro e Provisões Reais, $01,4,009$, doc. $\mathrm{n}^{\circ}$. 103. Há também uma cópia microfilmada cuja indicação é AHU_CA_CU_Baía, caixa 205, doc. 14690. Guilherme Pereira das Neves afirma a existência de outra cópia da carta no IHGB, lata 358, pasta 28, em 30 de março de 1797. Cf. Guilherme Pereira das Neves. Em busca de um ilustrado: Miguel Antônio de Melo (1766-1836). Acessado em 10 de janeiro de 2007 no sítio: www.realgabinete.com.br

${ }^{553}$ Jeanine Potelet. Projets d' expeditions et d'ataques sur le côtes du Brésil, 1796-1800., Caravelle, Cahiers du Monde Hispanique et luso-brésilien, n ${ }^{\circ}$ 54, IPEALT, Toulouse, 1990, p. 210.

${ }_{554}^{554}$ Idem, p. 211.

${ }_{555}$ Arthur Cézar Ferreira Reis. A ocupação de Caiena. In: Sérgio Buarque de Holanda (Dir.). História Geral da Civilização Brasileira: o Brasil Monárquico. São Paulo: Difel, 1976, Tomo II, Vol. I, pp. 278299.

${ }^{556} \mathrm{Idem}$.
} 
Borges de Barros nos conta sobre a viagem de Larcher. Em dezembro de 1795 Larcher chefiou o ataque ao navio luso-brasileiro Santo Antônio de Polifemo, comandado por Manoel do Nascimento da Costa, que comerciava com a Índia. Após o combate com alguns mortos, entre eles o Secretário de Estado de Goa, Antônio José de Almeida, Larcher e seus militares confiscaram o carregamento da embarcação portuguesa: açúcar, aguardente, tabaco, ferro e fardamento. Após o confronto, Larcher conseguiu um salvoconduto destinado aos demais navios franceses, possibilitando que sua embarcação se dirigisse à Bahia, sendo muito bem recebido assim que aportou no porto da capitania, em novembro de $1796^{557}$.

Foi durante sua estada de cerca de um mês em Salvador que ocorreram os contatos do capitão Larcher com o governador da capitania da Bahia, d. Fernando José de Portugal e Castro, e provavelmente com os homens que ocupavam os mais altos postos da governação local como o Secretário de Estado e Governo do Brasil, José Pires de Carvalho e Albuquerque, carregando consigo o decreto de abolição dos escravos das Ilhas Maurícias. Após esse breve período, Larcher retornou à Europa em janeiro de 1797, sendo obrigado a ficar em Lisboa durante o período de março a junho de 1797. Assim que conseguiu retornar à França, em 24 de agosto de 1797, o comandante Larcher informou ao Diretório, dispositivo supremo da República francesa, a boa recepção que encontrara na cidade de Salvador para com a Declaração dos Direitos do Homem, bem como a existência, entre os homens com os quais teve contato, da intenção de proclamar uma "república bahinense",558.

Diante disso, Larcher apresentou ao Diretório um ambicioso plano de ataque à Bahia $^{559}$. Larcher propôs aos membros do Diretório que a França invadisse Salvador com quatro vaisseaux de linha, três fragatas e duas flûtes, suficientes para transportar 1500 homens de tropa e 300 artilheiros, e 4000 fuzis com baioneta e a mesma quantidade de pólvora ${ }^{560}$. O ponto alto da sua argumentação residia no enorme descontentamento econômico que identificou entre os homens com os quais convivera durante sua estada em Salvador, em 1797, de maneira que caso o Diretório francês aprovasse a invasão, o sucesso da operação seria sancionado pelas riquezas que os

\footnotetext{
557 Cf. Francisco Borges de Barros. Novos Documentos para a História Colonial. Salvador: Imprensa Oficial do Estado, 1931, pp. 43-49.

558 Cf. Jeanine Potelet. Projects d'expéditions et d'attaques sur les côtes du Brésil (1796-1800). In: L'Amérique Latine face a La Révolution Française. Caravelle. Cahiers Du Monde Hispanique et LusoBrasilien, n. 54, pp. 209-222, Toulouse, 1990.

${ }^{559}$ Idem.

${ }^{560}$ Ibidem.
} 
habitantes da Bahia dariam em troca da ajuda concedida e por um tratado de comércio no qual a França conciliaria a vocação libertária e seus interesses comerciais ${ }^{561}$.

O Plano do Capitão Larcher de a França revolucionária transformar a capitania da Bahia em um protetorado para comércio exclusivo, como se sabe, não aconteceu. No entanto, esse projeto comprova que as "medidas tomadas para o socorro estrangeiro", segundo o Aviso № 9: "aviso ao clero e ao povo bahinense indouto", relacionam-se com a estada de um comandante francês na cidade de Salvador um pouco antes de deflagrado o movimento ${ }^{562}$. Assim, parece inegável que essa conflituosa conjuntura interna e externa do Império Português tenha sido capitalizada pelos autores dos boletins manuscritos, que além de criticarem a legitimidade da regência de d. João VI, valeram-se da cadência das palavras revolução, liberdade e república para explicitarem suas posições políticas.

Em um importante texto datado de 30 de março de 1800, no qual Domingos Vandelli confrontou os argumentos a favor e contra a celebração de um Tratado de Paz com a França, tais clivagens foram qualificadas como "partidos": pequenos agrupamentos informais e instáveis, que se constituíam em função da distribuição de cargos do governo ${ }^{563}$. Durante o período de 1796-1801, Vandelli cita a existência de dois "partidos": os pró-franceses (os pombalinos), com Antônio de Araújo de Azevedo, depois Conde da Barca, aliado político de d. Fernando José de Portugal e Castro, e os prós-ingleses, com d. Rodrigo de Sousa Coutinho. Talvez o pior incidente entre os dois partidos tenha ocorrido justamente em 1797, quando Araújo de Azevedo foi enviado a Paris pelo governo português para negociar um tratado com o governo do Diretório. $\mathrm{O}$ acordo fechado por ele previa, entre outros aspectos, ceder parte da Amazônia brasileira à França. Ao chegar a notícia desse tratado em Portugal, d. Rodrigo, que acabara de ascender ao ministério, conseguiu vetá-lo e o resultado foi que as autoridades revolucionárias francesas, insatisfeitas com o recuo, prenderam Araújo de Azevedo por alguns meses.

No entanto, ao analisar os antecedentes da assinatura do Tratado de Paz, em agosto de 1797, logo depois anulado, Joaquim Pintassilgo desmistifica a qualificação de "afrancesado" do grupo de Antônio de Araújo Braga, demonstrando que a principal

\footnotetext{
${ }^{561}$ Idem, p. 215.

${ }^{562}$ Cf. Aviso ao clero e ao povo bahinense indouto. In: Kátia M. de Queirós Mattoso. Presença francesa no Movimento Democrático Baiano de 1798. Salvador: Itapuã, 1969, p. 155.

563 BN, códice 9909, fls 311-318. Domingos Vandelli. Problema: se actualmente convém aceitar ou rejeitar a Paz.
} 
agenda política desse grupo não estava relacionada à França revolucionária, mas à tradicional posição de neutralidade da coroa portuguesa nos conflitos entre as nações europeias $^{564}$. A anulação do Tratado de Paz de 1797 com a França e a mudança no alinhamento político da Espanha obrigaram a diplomacia portuguesa a alterar sua posição no quadro europeu. Durante o período de 1797-1800, a coroa portuguesa deixou de pertencer à esfera da influência britânica e ficou sob constante pressão da França, como se viu.

O fato é que essa divisão nos quadros administrativos do reino repercutiu na capitania da Bahia. Ao propor uma modificação nos governos das capitanias do Brasil, d. Rodrigo de Sousa Coutinho, em 1797, indicou para o governo da Bahia, mesmo se dizendo contrariado, seu irmão Francisco Afonso Maurício de Sousa Coutinho, $1^{\circ}$. Visconde e $1^{\circ}$. Marquês de Maceió, e persuadiu o Príncipe Regente contra uma possível nomeação do governador da Bahia para o vice-reinado em razão da "nulidade de $d$. Fernando de Portugal, e o mau estado da administração da capitania da Bahia, que pode ser um prodígio, seja pelo aumento das rendas reais, seja pelos produtos que deve dar para o aumento da nossa marinha real [...] ${ }^{, 565}$. Nívia Pombo demonstra que a opinião de d. Rodrigo de Sousa Coutinho a respeito de d. Fernando relacionava-se ao lucrativo comércio estabelecido entre os negociantes de Salvador e os negociantes reinóis, que incomodava aos negociantes portugueses de tal sorte que d. Rodrigo via-se obrigado a pedir, em vão, que o governador da capitania da Bahia tomasse medidas cautelosas a esse respeito ${ }^{566}$.

Cumpre destacar que em 20 de setembro de 1797, Francisco Afonso Maurício de Sousa Coutinho encaminhou à coroa portuguesa um plano para incentivar o progresso das capitanias do Norte, prevendo, entre outras coisas, a criação de outros Tribunais da Relação, como em Pernambuco e a perda da importância jurisdicional da Capitania da Bahia sobre outras capitanias, como Mato Grosso ${ }^{567}$. Se compararmos o plano de Francisco de Sousa Coutinho com as diretrizes de d. Rodrigo de Sousa Coutinho,

\footnotetext{
564 Joaquim Pintassilgo. Diplomacia Política e Econômica na transição do século XVIII para o século XIX: o pensamento e a acção de Antônio de Araújo de Azevedo (Conde da Barca). Dissertação de Mestrado em História apresentada à Faculdade de Ciências Sociais e Humanas da Universidade Nova de Lisboa, Lisboa, 1987, pp. 152-190.

${ }^{565}$ Arquivo Nacional, doravante AN. Carta de d. Rodrigo de Sousa Coutinho ao príncipe regente d. João aconselhando a nomeação de governadores para as capitanias. Coleção Negócios de Portugal. Caixa 715, pacote 02, 1797.

${ }^{566}$ Cf. Nívia Pombo Cisne dos Santos. D. Rodrigo de Sousa Coutinho e a geração de 1790. Anais do X Encontro Regional de História, Rio de Janeiro, 2002.

${ }^{567} \mathrm{BN}$, Sessão de Manuscritos, I-28, 25, 30.
} 
delineadas em seu mais importante escrito, Memória sobre o melhoramento dos domínios de Sua Majestade na América ${ }^{568}$, constataremos que os irmãos estavam afinados politicamente.

Tanto mais que o projeto de reorganização da estrutura administrativa das colônias previa a criação de um novo Vice-Reinado no Pará, capaz de promover a defesa militar do território e de aglutinar as capitanias do norte, como o Maranhão e o Piauí e as do centro, Mato Grosso e Goiás. D. Rodrigo de Sousa Coutinho indicou dois nomes para ocupar o que viria a ser o Vice-Reinado do Pará: d. Bernardo José Maria da Silveira e Lorena, $5^{\circ}$ conde das Sarzedas ou o de Manuel Antônio Maria Baltasar de São Paio de Melo e Castro Moniz e Torres de Lusignano, o $2^{\circ}$ conde de Sampaio. Além disso, para ocupar o Vice-Reinado do Rio de Janeiro, que teria por objetivo:

"dirigir todas as capitanias do sul, de restabelecer a Real Fazenda daquela tão importante capitania, e de concorrer com o governador de Minas Gerais a impedir o extravio do ouro me impõe a dura lei, e contraria os meus princípios de lembrar à V. A.R. como o único vice-rei que pode nomear para o fim que se deseja meu irmão d. Francisco de Sousa. Satisfeito este dever que me pede a minha consciência, nada mais direi a este respeito, e só o sentimento do meu dever há que pode vencer o meu amor próprio, que lutava contra esta proposição $^{569, "}$.

A indicação do irmão de d. Rodrigo de Sousa Coutinho para a governação da Capitania da Bahia e depois para o Vice-Reinado do Rio de Janeiro além de comprovar a existência de uma centralidade compartilhada nos aspectos político e administrativo da colônia portuguesa, significava, por um lado, manter sob o controle do Ministro do Ultramar a prosperidade econômica que a capitania havia alcançado nos anos finais do século XVIII e, por outro, homogeneizar as diferenças entre os grupos das elites locais para melhor controlá-las, para que algumas reformas fossem implantadas com sucesso $^{570}$. Além disso, esse projeto comprova a grande divergência entre d. Rodrigo de Sousa Coutinho e o governador da capitania da Bahia, d. Fernando José de Portugal e Castro. Tudo leva a crer que essa questão esteja relacionada com o teor da segunda carta encontrada na Igreja do Carmo, em 20 de agosto de 1798, na qual os "Anônimos

\footnotetext{
${ }^{568}$ D. Rodrigo de Sousa Coutinho. Memória sobre o melhoramento dos domínios de Sua Majestade na América. In: Andrée Mansuy-Diniz Silva (Dir.). D. Rodrigo de Sousa Coutinho. Textos políticos, econômicos e financeiros (1783-1811). Lisboa: Banco de Portugal, 1993, t. II, p. 47-66.

${ }^{569}$ APUD, Nívia Pombo Cisne dos Santos. AN. Carta [...] ao príncipe regente d. João... Coleção Negócios de Portugal. Caixa 715, pacote 02, 5 de abril de 1797.

${ }^{570}$ Cf. Kenneth Maxwell. A devassa da devassa: a Inconfidência Mineira, 1750-1808. Rio de Janeiro: Paz \&Terra, 1978.
} 
Republicanos" do "Partido da Liberdade", se dirigiram ao próprio d. Fernando José de Portugal e Castro, desencadeando uma violenta repressão em razão dos seguintes termos:

"Illustrissimo e Excellentissimo Senhor, o Povo Bahinense, e Republicano na secção de 19 do prezente mez houve por bem eleger; e com efeito ordenar que seja Vossa Excellencia invocado compativelmente como cidadão Prezidente do Supremo [Tribu]nal da Democracia $B$ [ahinense] para as funcoens, da futura revolução, que segundo o Plebiscito se dará no prezente pelas duas horas da manhã, conforme o prescripto do Povo. Espera o Povo que Vossa Excellencia haja por bem o exposto. Vive et vale ${ }^{, 571}$.

${ }^{571}$ ADCA, vol.1, pp. 39-40. 


\section{Capítulo 3}

\section{Tempos de Negociação (1798-1800)}




\subsection{A Devassa das Devassas}

Passados pouco mais de dois meses das primeiras prisões decorrentes da deflagração do levante pelos boletins manuscritos, na manhã de 12 de agosto de 1798, cujas palavras de ordem: liberdade, república e revolução fizeram com que as autoridades os qualificasse "pasquins sediciosos", d. Fernando José de Portugal e Castro, então governador-general da Bahia, enviou uma extensa carta a d. Rodrigo de Souza Coutinho, Ministro de d. Maria $\mathrm{I}^{572}$ explicando os procedimentos adotados nas Devassas instauradas para se descobrir, respectivamente, o(s) autor(es) dos pasquins e os partícipes do movimento. Justificando-se, inicialmente, pelas providências imediatamente tomadas, "que pedia matéria tão delicada e melindrosa", o governador afirmou que para descobrir os autores dos "papéis" ele praticaria "todos os mais procedimentos que julgasse necessários". E assim o fez. Após as prisões e as informações obtidas nas primeiras acareações, o governador ponderou com d. Rodrigo sobre os meios mais adequados para se descobrir os réus:

"[...] reflectindo eu ao meio da devaça, posto que o mais conforme a Ley neste cazo, não he regularmente o [meio] mais eficaz para se descobrirem os Reos dessa qualidade de delicto, que procuram usar de todo o desfarce, segredo $e$ cautela quando o cometem, para que faltem testemunhas oculares que o comprovem, e que se devião fazer todas as averiguacoens, ainda que incertas e duvidosas [...]",

O caminho duvidoso escolhido por d. Fernando foi o exame de várias petições antigas que se encontravam na Secretaria de Estado e Governo do Brasil, sob o comando de José Pires de Carvalho e Albuquerque. O objetivo era confrontar as letras dos documentos oficiais com a letra dos "pasquins sediciosos". Note-se que os documentos entregues ao governador eram referentes às tropas urbanas de milícia, circunscrevendo o(s) réu(s) antecipadamente a um determinado grupo daquela sociedade, os milicianos. O exame resultou na descoberta de duas petições que indicavam ser de autoria de Domingos da Silva Lisboa, homem pardo ${ }^{574}$. A prisão foi

\footnotetext{
${ }^{572}$ Biblioteca Nacional, doravante BN, Sessão de Manuscritos, I-28, 26, 1, no. 13. Carta de 20 de outubro de 1798 .

573 Idem.

574 "Auto de exame, e combinação das Letras dos pesquins [sic], e mais papeis sedicciozos [sic], que apparecerão nas esquinas, ruas, e Igrejas desta Cidade que se achão incorporados na Devassa, que esta debaixo do N. 1 e do papel que elles estão escritos, com as letras de Domingos da Silva Lisboa nas
} 
decretada "ainda que esse indício fosse remoto e falível", pois o governador "ouviu dizer" ser o dito Domingos "alguém tanto solto de lingoa"575. Para além da frouxidão verbal do acusado, pesou sobre ele seu ofício.

Domingos da Silva Lisboa nasceu na Freguesia da Nossa Senhora da Encarnação, em Lisboa, era filho de pais desconhecidos, solteiro, requerente nos Auditórios e Alferes do Quarto Regimento de milícias da Salvador. Foi preso aos 43 anos de idade e foi descrito no termo de sua prisão, hábito e tonsura, pelo escrivão Veríssimo de Sousa Botelho como um:

"[...] homem pardo de Estatura alta groço do Corpo, Cabeça grande cabelo atado e Crespo, testa alta, sobrancelhas finas, e pretas, olhos grandes e pardos, nariz groso e afillado, boca grande, Lábios finos digo Lábios groços, Rosto comprido, e cheio de barba, estaua uestido Com camisa de bertanha, Siroula de pano de Linho, Sapatos nos pes [...]",576.

Era praxe para a averiguação de crimes, fossem eles quais fossem, a elaboração do termo de prisão, hábito e tonsura no mesmo dia, ou no dia seguinte da prisão do acusado, para assegurar sua integridade física, a partir da descrição de suas características $^{577}$. No caso de Domingos da Silva Lisboa, chama a atenção o fato de que a data exata de sua prisão não consta nos autos. Entretanto, pode-se asseverar pelo "auto de achada e aprehensão", realizado em 17 de agosto de 1798, que o acusado se não foi preso no mesmo dia, foi no dia seguinte. Contudo, seu termo de prisão foi elaborado oito meses depois, precisamente no dia 2 de março de 1799. Esse estranho procedimento também ocorreu com o próximo acusado.

A suspeita de d. Fernando em relação a Domingos da Silva Lisboa não se confirmou. Dez dias após a referida prisão, apareceram dois bilhetes destinados ao Prior dos Carmelitas Descalços, provando que não fora Domingos da Silva Lisboa o autor dos papéis, e o tal meio utilizado para a averiguação dos "cabeças" do movimento era de fato bem duvidoso. Não obstante, o governador novamente procurou evidências nas tais petições da Secretaria de Estado, encontrando três documentos que "comprovaram",

peticoens, que forão achadas em sua caza, e com o papel limpo, que ahi tambem se achou, e tudo se acha junto ao auto da achada, e aprehensão constante do appenso N. 9". In: Autos da Devassa da Conspiração dos Alfaiates. Salvador: Imprensa Oficial do Estado, 1998, vol. 1, pp. 86-89. Doravante ADCA.

${ }^{575}$ Ibidem; ADCA, vol 1, p. Asentada, p. 62.

576 “Cópia do termo de prizão, habito e tonçura feita ao Reo Domingos da Sylva Lisboa”. In: ADCA, vol.1, p. 143.

577 Arno Wehling. Administração portuguesa no Brasil de Pombal a D. João (1777-1808). Brasília: FUNCEP, 1986, vol. 6. Ver, especialmente, o capítulo VII, Administração Judiciária - Itinerários possíveis dos processos da justiça colonial, pp. 151-172. 
dessa feita, que os pasquins foram escritos por Luiz Gonzaga das Virgens e Veiga, homem igualmente pardo e soldado do Primeiro Regimento de Linha da Praça da Salvador e Quarta Companhia de Granadeiros ${ }^{578}$. Ocorre que dessa vez pesou sobre o réu um "requerimento atrevido", enviado para d. Fernando José de Portugal e Castro para que ele:

"[...] o nomeasse [Luiz Gonzaga das Virgens e Veiga] Ajudante do quarto Regimento de Milícias desta Cidade, composto de homens pardos, alegando que estes devião ser igualmente attendidos que os brancos, a que não deferi, e que conservava em meu poder pela sua extravagância [...] ,579.

Por analogia ao teor da carta, o governador chegou ao conteúdo dos pasquins sediciosos, uma vez que os papéis também “inculcavão aquela mesma igualdade entre os pardos, pretos e brancos". Isso posto, "faz não só conjecturar mas persuadir ser elle [Luiz Gonzaga das Virgens e Veiga], e não outrem o autor dos Papeis Sediciozoz”. O acusado nasceu em Salvador, era filho legítimo de Joaquim da Cunha Robý e de Rita Gomes, e, à época de sua prisão, tinha 36 anos. Foi descrito pelo escrivão Veríssimo de Sousa Botelho como um:

"[...] homem pardo de ordinária estatura cheio do Corpo, tem a cabeça Redonda, e examinando a não lhe achei Coroa, ou Sinal della, e Sim o Cabelo que hé preto, e algum tanto trocido, e crescido por detrás, e com falta delle adiante, Rosto Comprido, orelhas grandes testa alta, olhos pretos, sobrancelhas pretas, e finas, naris afillado, boca Rasgada, Lábio groços a barba feixada, está vestido Com Camisa de bertanha, e Siroulas de pano de Linho, embrulhado com hum Cazuzê de pano azul, Calçado somente com sapatos, e sem fiuellas $[\ldots]^{, 580}$.

Apesar de ter sido preso em 23 de agosto de 1798, seu termo de prisão foi elaborado em 24 de fevereiro de 1799, uma semana antes do termo de prisão do então primeiro acusado, Domingos da Silva Lisboa. Sentenciado o acusado em Relação de maneira bastante duvidosa e falível, d. Fernando cria ter resolvido com a maior prontidão o crime sobre os papéis sediciosos. Todavia, não foi o que ocorreu.

\footnotetext{
578 "Auto de combinação de letra dos pesquins [sic], e papeis sediciosos, que apparecerão nas esquinas, ruas e Igrejas desta Cidade, incorporados na Devassa debaixo do n. 1 com a letra de Luiz Gonzaga das Virgens nas peticoens que estão no appenso $n .4$ e papeis juntos por linha ao appenso $n$. 5, e com a letra de Domingos da Silva Lisboa nas peticoens,... ”. In: ADCA, vol. 1, pp.123-124.

${ }^{579}$ BN, Sessão de Manuscritos, I-28-26, 1, n. 13.

580 "Copia do termo de prizão habito e tonçura feita ao Reo Luis Gonzaga das Virgens”. In: ADCA, vol. 1, pp. 142-143.
} 
No dia 25 de agosto de 1798, dois dias após a prisão de Luiz Gonzaga, o governador é surpreendido por três denúncias, cujo teor anunciavam que outro pardo, João de Deus do Nascimento, havia convidado algumas pessoas do Regimento de Artilharia para uma reunião que seria realizada naquela noite, no Campo do Dique do Desterro, cujo objetivo era

"[...] formar huma rebelião, e revolução, que entravão outras pessoas que tão bem chamara ao seu partido rogando-lhe que se achasse na noite do dia seguinte em sua caza, para ir dali com elle [João de Deus] e os mais, ao Campo do Dique, a fim de ajustarem o modo, meios, e occazião em que havia ter efeito a projectada revolução[...] ${ }^{, 581}$.

A reunião no Campo do Dique, como se sabe, foi abortada. Uma das razões foi haver entre os partícipes quem reconhecesse os denunciantes e desconfiasse de suas presenças. Após esse episódio, no dia 26 de agosto do mesmo ano, outra devassa foi instaurada para investigar o crime de conjuração, sob os cuidados do desembargador Francisco Sabino da Costa Pinto. Várias pessoas foram presas ao longo de seis meses. Dentre elas, algumas apenas prestaram esclarecimentos, outras foram consideradas culpadas a priori, pois o que ocorreu foi a clivagem social para que houvesse diferenciação entre os acusados, conforme d. Fernando explicitou a d. Rodrigo de Sousa Coutinho:

"[...] o contexto dos Papeis sediciozoz, tão mal organizados, posto que sumamente atrevidos e descarados; o caracter $e$ qualidade do seu autor, e das principaes cabeças que trataram da rebelião taes como Luiz Gonzaga das Virgens, João de Deos Alfaiate, Lucas Dantas, e Luiz Pires lavrante, todos quatro homens pardos, de péssima conducta, e faltos de Religião, me fez capacitar, que nestes attentados, nem entravão pessoa de consideração, nem de entendimento, ou que tivessem conhecimento e Luzes, o que melhor se tem acontecido pelas confissoens destes Réos [...] ${ }^{, 582}$.

Segundo as informações dos autos, a situação não era exatamente a narrada na carta por d. Fernando José de Portugal e Castro. Paralelamente às prisões, os desembargadores Manoel Magalhães Pinto e Avellar de Barbedo e Francisco Sabino

\footnotetext{
581 "Denúncia publica jurada e necessária que dá Joaquim Joze da Veiga, homem pardo, forro, cazado e official de ferrador [...]"; "Denúncia publica [...] que dá o Capitão do Regimento Auxiliar dos homens pretos Joaquim Joze de Santa Anna [...]; "Denuncia publica [...] Joze Joaquim de Serqueira, homem branco e Soldado Garnadeiro do primeiro Regimento pago desta Praça [...]”. In: ADCA, vol. II, pp. 910-920.

${ }^{582}$ Carta de 20 de outubro de 1798. BN - Sessão de Manuscritos.
} 
Álvares da Costa Pinto colhiam, desde o dia 17 de agosto de 1798, os depoimentos dos presos e coordenavam as "Asentadas", depoimentos de testemunhas que, nesse caso, eram senhores de engenho, comerciantes, duas mulheres pardas e alguns homens livres que tinham alguma relação com os acusados.

As informações que se apreendem dos depoimentos dos acusados e de algumas testemunhas indicam a existência de uma sociabilidade política entre os partícipes do evento, que não esteve apenas circunscrita às médias e baixas camadas daquela sociedade, como d. Fernando insistia em afirmar para d. Rodrigo de Sousa Coutinho, pois, por ocasião do relato da prisão do primeiro acusado, Domingos da Silva Lisboa estivera “[...] aliciando e convidando para este fim [revolta], como convidarão, a vários Escravos de diversos Senhores, e alguns soldados, e outros indivíduos que foram sucessivamente prezos [...]",583.

D. Fernando José de Portugal e Castro, ao longo da carta, e mesmo na condução do processo, demonstrou bastante cautela em relação à procedência social dos homens que participaram da "revolução projectada". Durante os cinco meses em que os depoimentos foram tomados para se descobrir o autor dos "papeis revoltosos $e$ nervosos", as testemunhas afirmaram que "ouviram dizer" sobre o conteúdo dos ditos papéis, mas que não tinham certeza de seu autor. O testemunho de Francisco Pereira Rabello, homem branco, Alferes do Terço Auxiliar das Ordenanças e morador em Itapagipe, cercania de Salvador, é bastante significativo. Afirmou o Alferes:

"[...] que publicamente tem ouvido dizer que aparesserão huns certos papeis atrevidos pellas Esquinas, porem que elle [...] nem tem noticia de quem os fizesse ou para isso concorresse. E [...] estando elle no Citio do Bomfim e dandose a noticia da prizão de Domingos da Sylva Lisboa, elle testemunha dissera que o dito Lisboa não tinha cido Autor dos papeis mas sim que seos maiores e que so lhes faltava ter a Tropa a seo favor $[\ldots]^{, 584}$.

Doutor Manoel Magalhães Pinto de Avelar e Barbedo não verificou a informação do depoente, preferindo relatá-la ao governador. Não bastasse a denúncia de que os superiores das tropas estavam envolvidos no movimento, outro depoente, José Fernandes de Miranda, não só confirmou a informação, como acrescentou que, quando estivera em uma casa indo para São Bento, soubera que:

\footnotetext{
${ }^{583}$ Idem.

${ }^{584}$ ADCA, vol. 1, p. 61. Grifo meu.
} 
"existião quinhentos homens ocultos para darem execução ao projecto a que se dirigião os sobreditos papeis [pasquins], $e$ que elle testemunha [...] tinha ouvido contar em huma conversa de humas poucas [corroído] pessoas cujos nomes não se lembra ${ }^{, 585}$.

Ciente da possibilidade de os comandantes das tropas urbanas serem os "cabeças" do movimento e comandarem um grande número de homens para a execução do levante, d. Fernando não comentou essas informações na carta enviada a d. Rodrigo de Souza Coutinho, preferindo ganhar tempo na consecução das devassas, sem, contudo, verificar a procedência dessas denúncias. Como as informações evidenciavam uma maior amplitude social dos envolvidos, a condução dos processos caminhava para um engenhoso mecanismo de silenciamento das informações.

Nos depoimentos e na acareação entre o então acusado Domingos da Silva Lisboa e as testemunhas Bento José de Freitas e Thomas Pereira da Fonseca, foram longos oito meses, e os encontros ocorreram em três momentos diferentes. Ainda sob a condição de principal suspeito, no dia 27 de agosto de 1798, quinze dias após a publicação dos boletins manuscritos em locais públicos, os desembargadores perguntaram a Domingos da Silva Lisboa se era ele o autor dos pasquins publicados nas esquinas da Salvador e se reconhecia ser dele a letra de algumas petições que estavam na Secretaria de Estado. Domingos da Silva Lisboa respondeu negativamente à primeira pergunta e positivamente à segunda. $\mathrm{O}$ desembargador, contudo, solicitou que Domingos da Silva Lisboa:

"[...] dissesse a verdade, porquanto pello exame judicial a que se tinha procedido na prezença delle Menistro, feita huma exacta observação e Combinação, entre os sobreditos requerimentos por elle reconhecidos, e os sobreditos papeis revoltozos, se tinha achado, e assentado pellas razoens ahy alegadas, que erão estes escriturados por elle respondente, e a Letra delles a sua própria não obstante que desfigurada, ou desfarçada algum tanto ",586.

A insistência sobre a letra dos pasquins ser do acusado continuou por mais quatro perguntas, acrescidas da informação que "porquanto hera de voz pública" que o acusado falara "temerária e audaciozamente sobre matérias de Governo, e Religião", posto ser estes, para o desembargador, fortes indícios de que o acusado era capaz de escrever os pasquins. Após as negativas do acusado, sob a argumentação de que vivia

\footnotetext{
585 Idem.

${ }^{586}$ ADCA, vol. 1, p. 93.
} 
"catholicamente e sob as Leys de seo Governo", uma nova pergunta foi feita, referente ao teor das obras apreendidas na casa do acusado pelas autoridades ${ }^{587}$. Assim, "foi proguntado se elle respondente [Domingos da Silva Lisboa] reconhecia como seos, huns verços feitos a Liberdade, e igualdade, que se aprehenderão em sua Caza, imediatamente a sua prizão" 588 .

O acusado respondeu que os tais versos não eram seus e que se foram encontrados entre seus pertences é porque foram postos por um homem chamado Manoel Henriques, que ficara abrigado em sua casa por dois meses, e tinha o intuito de lhe prejudicar, pois fora expulso por ser ele muito bêbado. Com a mesma veemência sobre a letra dos pasquins, insistiu-se com o acusado sobre a pertença dos versos, dado que imediatamente após a sua prisão, Domingos da Silva Lisboa havia pedido ao carcereiro que fosse até a sua casa retirar uns versos sobre a liberdade que haviam sido feitos "pello defunto Salvador Pires ${ }^{589}$, ou no seu tempo".

O acusado respondeu afirmando que era "[...] o sobredito Henriques, o qual dizia ter Introdução, e conhecimento com o defunto Salvador Pires de Carvalho". Ainda que o desembargador tivesse mencionado o nome do proeminente defunto, nada mais disse a seu respeito naquele momento. Já ao final do depoimento, as perguntas feitas referiram-se às obras encontradas na casa do acusado, entre elas "hum papel revolucionario intitulado Orador dos Estados Geraes" ${ }^{\$ 290}$, pelo que o acusado reconheceu serem suas, sem, contudo, concordar com a doutrina que elas incitavam. Todavia, foi na segunda etapa de depoimentos com Domingos da Silva Lisboa, realizada alguns meses depois, no dia 26 de fevereiro de 1799, que foram esclarecidas

\footnotetext{
${ }^{587}$ Cf. Auto de aprehensão nos bens achados em caza de Domingos da Silva Lisboa, e depozito delles. ADCA, vol. I, pp. 81-82. Nos autos consta a apreensão do seguinte: "huma caixa grande já velha, e dentro della bastantes Livros, e alguns desencadernados, e huã boceta grande de folha, huma estante de pes com cento, e setenta e nove Livros grandes e pequenos de varios Autores, e hum de Capa de pergaminho ainda em branco com alguns asentos [...]".

${ }^{588}$ ADCA., vol I, p. 94.

${ }^{589}$ Salvador Pires de Carvallho e Albuquerque, acadêmico renascido, morreu em 1795 e era um dos filhos de José Pires de Carvalho e Albuquerque, proprietário do morgado dos Pires e do morgado da Casa da Torre de Garcia d'Ávila, herdado pela prática de endogamia familiar e social pelo casamento com d. Leonor Pereira Marinho de Aragão. Amealhou uma das maiores fortunas da Bahia de meados do século XVIII. Cf. Luiz Alberto Torres Moniz Bandeira. O Feudo. A casa da torre de Garcia d'Ávila: da conquista dos sertões à independência. Rio de Janeiro: Civilização Brasileira, 2000, capítulo X, pp. 313353; Pedro Calmon. Introdução e notas ao catálogo genealógico de Frei Jaboatão. Salvador: Imprensa Oficial do Estado, 1985.

${ }^{590}$ Cf. Kátia M. de Queirós Mattoso. Presença francesa no Movimento Democrático Baiano de 1798. Salvador: Itapuã, 1969. Sobre o teor da obra "Orador dos Estados Gerais", ver especialmente o capítulo 2. Cabe ressaltar que, segundo a autora, a obra fazia parte apenas das bibliotecas de outros envolvidos na Conjuração Baiana de 1798, nomeadamente, Cipriano José Barata de Almeida e Hermógenes Francisco de Aguillar Pantoja.
} 
as questões apenas apontadas no primeiro depoimento. A principal questão da segunda etapa, para os desembargadores, referia-se às obras encontradas na casa do acusado, que este insistiu não saber quem era o dono. Entretanto, o acusado modificou sua resposta, acrescentando uma informação preciosa:

"o dito papel [versos sobre liberdade e igualdade] lhe confiara sendo vivo Salvador Pires de Carvalho, para que elle Respondente ovesi e sobre ele proferise o seu sentimento, [...] porem que elle Respondente nunca aprovara as maximas que o dito papel de sua propria letra, e nem era capás elle Respondente dizer o Juizo [corroído] semelhantes doutrinas pelo digo tendo vivido catolicamente, e como bom Vasalo"591.

O desembargador afirmou que essas declarações eram falsas e fraudulentas, uma vez que o acusado havia inventado a existência do tal Manoel Henriques para se livrar das acusações, não obstante a minuciosa descrição que Domingos da Silva Lisboa fornecera sobre o dito Manoel Henriques ${ }^{592}$. Em contrapartida, não é o caso de se considerar que o desembargador não tenha ouvido o acusado afirmar que era das relações de Salvador Pires de Carvalho e Albuquerque. Todavia, essa questão foi retomada pelo próprio acusado apenas na acareação entre ele, o carcereiro Bento Joze de Freitas e o escrevente Thomas Pereira de Afonseca.

No dia 6 de março de 1799, iniciou-se a acareação com a leitura das perguntas e respostas obtidas nos depoimentos de Domingos da Silva Lisboa e perguntou-se se o acusado concordava com o teor das informações. Ratificando-as, o acusado presenciou o testemunho do carcereiro Bento, para depois confirmá-lo. O carcereiro confirmou que o acusado lhe dissera sobre "humas Sátiras francezas que lhe dera Salvador Pires de Carvalho já defunto", e se "tirião [...] aprehendido os seos papeis ou se havia alguma pessoa que lhe fosse tirar as ditas Sátiras ou versos" $" 593$. Domingos da Silva Lisboa não só confirmou a informação como fez questão de mencionar novamente o modo pelo qual ele tomara conhecimento das tais Sátiras: pelas mãos de Salvador de Carvalho e Albuquerque.

Novamente, nada foi dito a respeito. Chamado Thomaz Pereira de Afonseca a participar da acareação, feitas as perguntas e ratificações de praxe, o acusado mais uma vez cita o dito Salvador, mas acrescenta uma nova informação:

\footnotetext{
${ }^{591}$ ADCA, vol. 1, p. 98.

592 Idem.

${ }^{593}$ Ibidem, p. 100.
} 
"[...] hera verdade o que o Cariante [Thomaz] tinha declarado porquanto elle mesmo Cariado [Domingos] he que tinha dado ao Cariante para tresladar o referido papel, porem que fora por ordem do defunto Salvador Pires de Carvalho que o dera a elle Cariado, assim como igualmente ao dito Cariante outro papel intitulado e que nomeia Secreto dos Jesuitas $^{594}$, o qual tambem ouvera do mesmo Salvador Pires de Carvalho" $" 595$.

Dessa vez, não havia como o desembargador desconsiderar a informação de que obras proibidas pelo aparato repressivo da coroa portuguesa não só circulavam na Salvador da época, junto com folhetos de propaganda antijesuítica, como eram traduzidas e discutidas em reuniões de caráter eminentemente político. Nitidamente acuado, o desembargador perguntou o motivo pelo qual Domingos da Silva Lisboa, logo de início, não afirmara ter sido ele que mandara "tresladar o referido papel, antes pelo contrário afirmara lhe tinha sido Comunicado pelo sobredito Salvador Pires de Carvalho para ser elle interpor o seu pareser" ${ }^{, 596}$. Domingos da Silva Lisboa respondeu que:

"[...] perturbado da prizão se não lembrara de fazer a referida declaração ao longo da primeira vez que fora proguntado. E [...] por duvidar que fosse acreditada a sua comunicação com o dito senhor Salvador Pires de Carvalho visto ser elle Cariado de inferior qualidade e ultimamente por ter se passado intervallo de annos, e elle Cariado ter perdido a lembrança do mesmo papel e ignorar se estava ou não em seu puder ${ }^{3597}$.

O desembargador encerrou a acareação e nada mais foi perguntado a respeito. A resposta de Domingos da Silva Lisboa trouxe à luz que, a despeito da mácula da cor, raça e nascimento ser os critérios definidores das posições sociais da sociedade

\footnotetext{
${ }^{594}$ Há fortes indícios de que Segredo dos Jesuítas é a denominação utilizada nas reuniões sediciosas para o libelo editado originalmente em latim "Monita privata Societatis Jesu", em 1612 por um ex-jesuíta polaco banido da Companhia. Depois de circular por mais de um século sob a forma manuscrita em Portugal, foi publicado primeiro em 1767 ainda em língua latina, depois, já na língua portuguesa, a obra foi editada em 1820, 1834, 1859, 1881, 1901 e 1910. Ocorre que por ocasião da expulsão dos jesuítas, em 1759, Pombal mandou que se aumentasse a divulgação do manuscrito para que se tivesse uma imagem negativa dos jesuítas, que à época eram vistos como uma organização destituída de qualquer interesse no progresso das nações. No último quartel do século XVIII, entretanto, tem-se notícia de que as edições do manual foram realizadas em Portugal e na França, por centros republicanos e maçons, o que sugere que o manuscrito pode ter sido instrumentalizado em termos políticos para o movimento em questão. Cf. José Eduardo Franco \& Christine Vogel. Monita Secreta: instruções secretas dos jesuítas. História de um manual conspiracionista". Lisboa: Roma Editora, 2002. Agradeço ao Prof. Eduardo Franco por enviarme a obra.

${ }^{595}$ ADCA, vol. 1, p. 101

596 Ibidem.

${ }^{597}$ Ibidem. Grifo meu.
} 
soteropolitana, em 1798, havia uma fluida relação de homens provenientes de vários setores, mas especialmente entre senhores de escravos e de terras, escravos urbanos e os milicianos das tropas urbanas. O depoimento do dito Domingos sugere, ainda, que essa sociabilidade tinha um fim específico que superava a cordialidade entre os convivas, pois as reuniões ocorridas nas casas dos senhores de escravos e nas tabernas tinham como tema recorrente a política local, as ideias de francezia ${ }^{598}$ e os acontecimentos revolucionários na França.

Nas declarações dos depoentes, muitos deles forneceram detalhes do conteúdo dos pasquins e dos pressupostos políticos dos partícipes, por "ouvir dizer" a respeito, porque tiveram conhecimento dos fatos por "ouvirem de voz pública" ou "ouvir dizer publicamente". Diante do nível de boato que caracterizava aquela sociedade, as autoridades locais não desconheciam o fato de que havia uma intensa circulação das notícias francesas e da "revolução projectada nesta Praça". A circulação dessas ideias não parece ter sido a maior preocupação das autoridades, a despeito da censura régia. $\mathrm{O}$ problema era saber o uso que se poderia fazer dos princípios de "francezia", por um setor específico daquela sociedade, pois o circuito das ideias começava pelo alto, com os homens "principais", e as informações eram rapidamente pulverizadas entre os homens livres, pobres, pardos e escravos citadinos ${ }^{599}$.

No dia 12 de fevereiro de 1799, iniciou-se o depoimento de outro acusado de participar da "projectada revolução" e ser sectário dos princípios franceses. O acusado era Francisco Muniz Barreto de Aragão, branco, filho de Antônio Felix de Aragão e Souza e Bernarda de Assumpção Muniz Barreto, solteiro e professor régio de gramática na vila do Rio de Contas na Comarca de Jacobina ${ }^{600}$. O Desembargador Francisco

\footnotetext{
${ }^{598}$ A ideia de Francezia concebida à época, via de regra, relacionava-se às doutrinas que questionavam o Estado Absolutista, especialmente os princípios revolucionários franceses difundidos pelos Clubes, após 1789. Em ofício ao governador d. Fernando José de Portugal e Castro, datado de 21 de fevereiro de 1792, Martinho de Melo e Castro expressou com bastante clareza a ideia que os agentes metropolitanos faziam do termo. Afirma o Ministro "[...] servindo para espalhar a semente da Insurreição entre Vassalos dos seus respectivos Soberanos, [...] já de escritos sediciozos, e incendiários, conseguindo por estas abomináveis maquinaçoens o alterar em alguns deles a tranqüilidade de que gozavão os Povos debaixo do Sábio e paternal Governo dos seus naturaes e Legítimos Imperantes [...]”. Sobre a francezia chegar aos domínios coloniais portugueses, o Ministro alertou: "Com a propagação destes abomináveis princípios atearam os mesmos Clubs nas Colônias Francezas o fogo da Revolta, e da insurreição, fazendo levantar os Escravos contra os seus Senhores, e excitando na parte Franceza da Ilha de São Domingos huma Guerra Civil entre uns e outros, em que cometerão as mais atrozes crueldades, que jamais se praticarão [...]”. BN - Sessão de Manuscritos, doc. II - 33.29.29.

599 Cf. Florisvaldo Mattos. A comunicação social na Revolução dos alfaiates. Salvador: Assembleia Legislativa do Estado/Academia de Letras da Bahia, 1998, $2^{\text {a }}$. edição. Ler, especialmente, o capítulo 5: 1798: a teia da comunicação, pp. 71-90.

600 "Perguntas a Francisco Moniz Barreto de Aragão, homem branco e prezo nas cadeas da Relação". In: ADCA, vol. 2, pp. 886-902.
} 
Sabino Álvares da Costa Pinto iniciou o interrogatório perguntando para o acusado sobre as suas relações sociais na Salvador e se ele era sectário das ideias de francezia. O acusado respondeu que em 1797 vivera na cidade de Salvador e fora vizinho de José Borges de Barros "homem pardo, que pouco tempo antes tinha vindo aqui [Salvador] da Ilha da Madeira, com o dizignio de se estabelecer em negócio [...]"601. O desembargador perguntou sobre o teor das conversas entre o acusado e José Borges, pelo que a resposta foi que:

"todas as suas conversaçoens com Joze Borges se reduzião a reflexões sinceras, sobre o governo economico desta Terra, $e$ sobre o Estado Político da Europa, segundo as poucas notícias, que a elle ambos podião chegar a este respeito, sem que jamais costumassem concorrer na dita caza outras algumas pessoas ",602.

As perguntas subsequentes referiram-se ao contato do professor com o Tenente Hermógenes Francisco de Aguillar e com o escravo de Dona Maria Francisca de Aragão, o pardo Lira. O objetivo era saber se o teor das conversas era sobre o "Systema da Nação Francesa". O acusado respondeu que conhecia ambos os homens e que entre eles o teor das conversas "nunca se animara á semelhantes absurdos, [pois ele] antes sempre abominou e abomina tais princípios" ${ }^{\prime 63}$. Após várias perguntas, o desembargador questionou se o professor tinha em seu poder alguns "manuscritos libertinos e sediciosos que persuadissem os povos para o systhema da revolução". O acusado respondeu que certa feita teve em seu poder alguns manuscritos "traduzidos de huma obra de Valney, intitulada a Revolução dos tempos passados, em que figuravão os povos revoltados pelos diversos systemas de Religião, representados na Turquia, e na Rússia [... $]^{604, \%}$. O acusado continuou seu depoimento afirmando, entretanto, que a obra não estava mais em seu poder, pois a tinha emprestado para algumas pessoas que estavam de partida para a corte.

No final da primeira parte do depoimento do professor Francisco Muniz, o desembargador apresentou as obras confiscadas em sua casa, por ocasião de sua prisão, e perguntou se o acusado as reconhecia como dele. Afirmando a pergunta, o acusado foi confrontado com a apresentação de uma cópia manuscrita de Julia ou a Nova Heloísa,

\footnotetext{
${ }^{601}$ Idem, p. 887.

${ }^{602}$ Ibidem.

${ }^{603}$ Idem, p. 888.

${ }^{604}$ Idem, p. 889.
} 
de Rousseau, e mais dois tomos de uma obra em verso do mesmo autor, que o desembargador perguntou se o acusado reconhecia a letra da cópia como sua. Após confirmar ser o dono do manuscrito, o professor foi questionado pelo desembargador "por que motivo sendo perguntado a este respeito tão repetidamente, e por tantos modos, se firmou uma redonda negativa, agora desfeita e convencida?"605.

O professor disse que os tais manuscritos eram para sua leitura pessoal, sem que se destinasse a "algumas sinistras intencoens contra o Estado". Encerrou-se o depoimento sem nada constar. Passados cinco dias, o professor foi novamente chamado a depor. Dessa feita, pesou sobre ele o depoimento de Hermógenes Francisco de Aguillar Pantoja, branco, Tenente do Segundo Regimento de linha de Salvador e filho legítimo do Sargento-Mor Pantoja ${ }^{606}$. O tenente havia dito que o professor:

"não só frequentava esta sociedade [reuniões], mas que até assistia as diversas práticas [...] sobre matérias secidiozas [sic], sobre a constituição, e liberdade da Nação Franceza, applicando estas ideias ao povo da Bahia com o perniciozo projecto [de] conseguir huma sublevação" ${ }^{, 607}$.

O desembargador prosseguiu com seus argumentos, afirmando que o professor espalhara as décimas sobre liberdade "por diversas mãos, até o ponto de a conservarem de memória alguns dos cúmplices desta infame rebelião, sem que possa escuza-lo a frágil coartada [...] por se acharem corrigidos e emendados por elle [...]",608. O longo depoimento atingiu os seus momentos finais com o desembargador arvorando o fato de que tanto o professor quanto o Tenente Hermógenes eram homens brancos e "collocados entre os povos", portanto, era inadmissível que homens como eles fossem sectários das ideias de francezia, cujo objetivo precípuo era "o contágio de semelhante lição, e o mal que vinha em consequência de sua descoberta" ${ }^{\text {,09. }}$.

Note-se que, nos depoimentos sobre a acusação de Domingos da Silva Lisboa e Luiz Gonzaga das Virgens, as informações fornecidas pelos pardos e escravos não foram averiguadas, não obstante terem sido utilizadas com o professor e o tenente para demonstrar o lugar e o papel de cada um naquela sociedade. As informações dos escravos e de alguns pardos ora eram negligenciadas ora eram utilizadas para um fim

\footnotetext{
${ }^{605}$ Idem, p. 891.

606 "Copia do termo de prizão habito e tonçura feito ao reo Hermógenes Francisco de Aguillar, Tenente do Segundo Regimento de Linha desta Praça, ao vinte dias do mês de Fevereiro de 1799". In: ADCA, vol. II, p. 1085.

607 Idem, p. 893.

608 Idem, p. 893.

${ }^{609}$ Idem.
} 
específico. Do total de 32 pessoas presas, dez eram escravos e foram indiciados na devassa realizada pelo desembargador do Tribunal da Relação, Francisco Sabino Álvares da Costa Pinto, para verificar os "fatos conexos" aos pasquins "sediciosos", publicizados na manhã do dia 12 de agosto de 1798.

O modo pelo qual o desembargador chegou à participação dos escravos é bastante significativo e, conforme a expressão de um dos proprietários, fez-se "pronta entrega dos escravos" "610. Temerosos por serem acusados de conivência em ações "sediciosas", conforme a informação do autor anônimo da "Relação de Francesia formada pelos homens pardos na cidade da Bahia no ano de 1798",611, os senhores resolveram não só entregar seus escravos como dois deles foram importantes testemunhas nas devassas instauradas sobre o levante que se intentara em Salvador.

Em meados de 1799, já eram nove escravos, pois um deles, Antônio José, morrera na prisão, aparentemente por um mau súbito, depois que se alimentou de uma comida trazida por outro escravo do mesmo dono, o Tenente Coronel Caetano Maurício Machado $^{612}$. Dos escravos indiciados nos Autos, quase todos eram pardos e nascidos na Bahia $^{613}$, domésticos, citadinos, sabiam ler e escrever e socializavam pelas ruas da cidade de Salvador. Conforme as informações nos autos fornecidas pelos réus Luiz Gonzaga das Virgens e Veiga, João de Deus do Nascimento e Manuel Faustino, os escravos presenciaram e participaram de encontros de seus senhores com homens livres, alguns brancos, outros pardos; alguns militares, oficiais de baixa e média patente; artesãos; e ainda alguns intelectuais ${ }^{614}$.

Ignácio Pires, 20 anos, escravo do Secretário do Estado e Governo do Brasil, José Pires de Carvalho e Albuquerque, foi a única testemunha que teve direito ao "Auto de Justificação", entre os pardos e cativos. Trata-se de uma auto de defesa na qual o

\footnotetext{
${ }^{610}$ ADCA, vol. II, p. 925, Testemunho de Manoel Vilella de Carvalho, proprietário do escravo José Felix da Costa.

${ }^{611}$ Arquivo do IHGB, Descripção da Bahia, Tomo IV, DL, 399.2, Relação de francesia formada pelos homens pardos da cidade do Salvador, pp. 294-301.

${ }^{612}$ ADCA, vol. I, pp. 356-357.

${ }^{613}$ Dos dez escravos indiciados, o único preso e processado foi o escravo alfaiate de aluguel, Vicente. Escravo africano da mina, Vicente era de propriedade de Bernardino de Sena e Araújo, Tabelião de Notas da Bahia. Cf. Luís Henrique Dias Tavares. Os escravos na sedição de 1798 na Bahia. In: Da sedição de 1798 à Revolta de 1824 na Bahia. São Paulo/Salvador: Unesp/Editora da UFBA, 2003, pp. 85-124.

${ }^{614} \mathrm{Cf}$. "Relação dos reos prezoz, a que dis respeito o alvará para se lhe correr folha. ADCA, vol. II, pp 939-944; BN - 28, 26, 1, n. 13, sessão de manuscritos; "Relação das pessoas que se achão prezas na cadea desta Cidade da Bahia por ocazião dos factos revolucionários de que por Portaria do Illmo. Exmo. Governador e Capitão General desta Capitania Dom Fernando José de Portugal tem devassado o Dezembargador dos agravos da Relação desta Cidade, o Doutor Francisco Álvares da Costa Pinto, Bahia 23 de outubro de 1798". ADCA, vol. II, pp. 812-815.
} 
escravo se isentou das denúncias que lhe foram imputadas pelos réus, dando a entender que não podia responder pelos seus atos, pois:

[...] há quatro, ou Sinco annos, pouco mais, ou menos [ele] foi atacado de moléstia capital, que lhe desordenou o juízo [...] [a moléstia] he da qualidade que possa Segunda vez Sobrevir por alguns acidentes, ou em algumas ocazioens $[\ldots]^{615}$.

Testemunharam a favor do escravo Ignácio Pires: o cirurgião Manuel José Estrela, o oficial da Secretaria de Estado e Governo do Brasil João Nepumoceno da Trindade, o comerciante José Joaquim Pinheiro e o caixeiro Custódio José Pinto Coelho. Todos os homens eram brancos, "collocados entre os povos" e tinham relações estreitas com o Secretário de Estado, sobretudo no que se refere ao arrendamento de algumas de suas terras no norte da capitania da Bahia ${ }^{616}$. A presença de escravos no evento remete-se à outra ponta que essa condição legal designava: seus proprietários. Os proprietários dos escravos citados nas devassas da Conjuração Baiana de 1798 são um grupo homogêneo, pequeno e composto pelos donos das maiores fortunas da Salvador de 1798, que Luís dos Santos Vilhena o chamou de corporação dos enteados.

Como se teve oportunidade de demonstrar anteriormente, foram várias as denúncias que acusavam José Pires de Carvalho e Albuquerque de enriquecimento ilícito, de despotismo em relação à arrecadação do tabaco, de disputa pela herança do principal morgadio da Bahia, o da Casa da Torre dos Garcia D’Ávila, e principalmente de uma atuação duvidosa na Secretaria de Estado em comunhão com alguns desembargadores do Tribunal da Relação da Bahia, sobretudo o desembargador Costa Pinto, e com outros proprietários de escravos entregues à justiça que formularam culpa sobre os quatro acusados de crime de lesa-majestade de primeira cabeça. Por tudo isso e para livrar o grupo que comandava, José Pires de Carvalho e Albuquerque passou na casa de outros donos de escravos para recolher os escravos e entregá-los pessoalmente à justiça. Talvez seja por isso também que dois senhores de escravos presos no Segredo da Relação tenham elaborado as principais acusações sobre os réus da Conjuração Baiana de 1798.

\footnotetext{
615 "Autos de justificação de Ignácio Pires menor de vinte annos, escravo do Capitão Mor Joze Pires de Carvalho e Albuquerque" In: ADCA, vol. II, pp. 1088-1099.

${ }^{616} \mathrm{Cf}$. Tombo dos bens patrimoniaes da Casa da Torre, levantada em 21 de outubro de 1815, por Antônio Joaquim de Carvalho e Albuquerque Cavalcanti de Avila Pereira. Annaes do Archivo Público e Museu do Estado da Bahia, volume XI, Bahia, 1923, pp. 81 a 87.
} 
Francisco Vicente Viana, que foi ouvidor da comarca da Bahia, formulou culpa sobre a participação de Luiz Gonzaga das Virgens na "projectada revolução",617. Em seu testemunho, após isentar seu escravo de qualquer participação mais efetiva na reunião do dia 25 de agosto no Campo do Dique do Desterro, afirmou que soube:

“[...] pela voz pública sabe que se tentava fazer hum levantamento nesta Cidade [Salvador] com saque, e assassino com effeito de se estabelecer nella hum Governo Democrático, livre e independente; de cujo artefacto são os authores huns poucos mulatos em que tinhão a primeira parte Luiz Gonzaga das Virgens [...]",618.

Francisco Vicente Viana terminou seu testemunho afirmando que o tal "fuão",619, Luiz Gonzaga das Virgens, era de "hum carather insolente, e dezavergonhado, bem capaz de entrar nesta diabólica empreza". No mesmo dia, foi chamado a formular culpa outro senhor de escravo, Manoel José Villela de Carvalho, que também era negociante da praça da Bahia e ajudante de Ordens do Governo. Seguindo o padrão do testemunho de Francisco Vicente Viana, Manoel José isentou seus dois escravos de qualquer culpa nos crimes investigados, afirmando que no dia em que fora preso o dito "fuão", Luiz Gonzaga, era público:

"[...] e notoriamente, que Se projectava fazer hum levante nesta Cidade [Salvador] com saque, e assassinos para se estabelecer um Governo Democrático, livre e independente, e que os autores desta empreza forão huns poucos de mulatos, $e$ animozos entre os quais forão os primeiros Luiz Gonzaga das Virgens $[\ldots]^{,, 620}$.

Do total de 13 testemunhas que formularam culpa sobre Luiz Gonzaga das Virgens e, depois, em outra devassa, sobre mais três pardos, o poder local aproveitou-se da animosidade existente entre pardos livres e escravos para convocar que os escravos depusessem sobre o que eles sabiam acerca da "revolução projectada". José Felix da Costa, escravo de Francisco Vicente Viana, forneceu um dos mais importantes testemunhos dos processos. Disse que fora chamar um "fuão" que morava na casa do

\footnotetext{
${ }^{617}$ Cf. "Testemunhas da devassa...". Ler, especialmente a testemunha n. 6, Francisco Vicente Viana, ADCA, vol. 2, pp. 923-924.

${ }^{618}$ Idem.

${ }^{619}$ Nos depoimentos de Francisco Vicente Viana e de Manoel José Villela de Carvalho, ambos senhores de escravos, é frequente o termo "fuão" referente aos réus pardos acusados de crime de lesa-majestade.

${ }^{620} \mathrm{Cf}$. Testemunho de Manoel Jozé Villela de Carvalho, homem branco solteiro Negociante desta praça e morador a rua direita da Sé.." ADCA, vol. 2, pp. 924-925.
} 
Secretário de Estado José Pires de Carvalho e Albuquerque. Entrando ele, testemunha, na casa, nela achou um pardo "fuão" que disse que há dias o andava procurando para:

"[...] lhe comunicar hum particular em beneficio de todos, têm elleito a vossê para entrar nelle [levante], porque temos muitas pessoas Principais, e ate o Excellentissimo Governador que Sabe disso, e convém; porém não quer que se saiba, e temos os dous Regimentos dos pardos, e dos negros a nosso favor declarando-lhe ao mesmo tempo consistir o particular em hum levantamento, por meio do qual se propunha reduziro continente do Brazil a huma Republica, o que havia de acontecer no dia em que estivesse de Guarda o Regimento Pago de Artilharia [...] "621.

José Felix continuou seu testemunho, afirmando que o pardo dissera que mesmo os oficiais do Regimento pago da artilharia estavam prontos a entregar as guardas e as "pessoas principaes interessadas no mesmo levantamento, esperavão duas embarcacoens em Socorro dele, pois já tinham escrito para fora sem declarar para onde ${ }^{\Uparrow 22}$. Perguntado sobre a causa para um governo republicano, o escravo respondeu que:

"[...] era por evitar o grande furto que o Príncipe faz a Praça desta Cidade, o que bem se conheceo na demora do grande comboio; que ultimamente daqui Sahio, ficando os Negociantes a pedirem huma esmolla: e que havião já mais de trezentas pessoas a seo partido [revolta], além da escravatura dos Engenhos do Ferrão, e Bulcão ${ }^{623}$, que estavão prontos $[\ldots]^{, 624}$.

Os engenhos Ferrão e Bulcão eram de propriedade de Joaquim Ignácio de Siqueira Bulcão, cunhado do Secretário de Estado José Pires de Carvalho e Albuquerque. Após mais algumas informações, das quais sugeriu ser Luiz Gonzaga das Virgens um dos "cabeças" do levante, o escravo terminou seu testemunho afirmando

\footnotetext{
${ }^{621}$ Cf. "Testemunha de Jozé Felix da Costa, homem pardo escravo do Doutor Francisco Vicente Viana em cuja casa assistia ao tempo em que foi preso..."., ADCA, pp. 925-928.

${ }^{622}$ Idem, p. 926.

${ }^{623}$ Joaquim Inácio de Siqueira Bulcão, professo na Ordem de Cristo, proprietário de vários engenhos de açúcar junto com a família de seu cunhado José Pires de Carvalho e Albuquerque, Secretário de Estado e Guerra do Brasil. Joaquim Inácio escondera dois dos réus da revolta baiana de 1798 em suas terras após a reunião no Campo do Dique do Desterro, todavia, não foi chamado a testemunhar nas devassas. Joaquim Inácio empregara mecanismos novos para obter melhor proveito ao limpar e descascar algodão, arroz e o café, além de empregar métodos "modernos" para o cultivo do tabaco e o açúcar. Cf. AHU_CU_CA_BAÍA, doc. 19693 - Carta de José da Silva Lisboa para d. Rodrigo de Souza Coutinho, sobre os engenhos de assucar e os mechanismos empregados na sua preparação, propondo que se conferisse uma recompensa a Joaquim Inácio de Siqueira Bulcão, por ter sido o primeiro proprietário que adoptara novos processos de moagem da cana. Bahia, 28 de março de 1799.
}

${ }^{624}$ ADCA, p. 926. 
que não imaginava que fosse verdadeiro o dito levante e, por isso, não tinha comentado nada com ninguém, apenas com o pardo cabeleireiro Francisco Villaça que após as prisões decorrentes do encontro do dia 25 de agosto no Campo do Dique do Desterro, aconselhara-lhe a delatar tudo o que soubera a seu senhor.

Chamado novamente para uma acareação com Luiz Gonzaga das Virgens, na qual José Felix da Costa afirmou que Luiz Gonzaga queixava-se constantemente da situação dos milicianos, cabos de esquadras e cadetes, o cativo confirmou a afirmação de que Luiz Gonzaga das Virgens tinha perguntado sobre "huns papeis sediciozoz que tinhão apparecido",e aproveitou para afirmar ao Desembargador Francisco Sabino Álvares da Costa Pinto que o careante "sustentou a sua resposta com todo o vigor, dizendo mais [...], que quem os tinha feito [pasquins sediciosos] era tolo; pois devia terse aconcelhado com elle careado ${ }^{625}$.

Luís Leal, escravo de Manoel José Vilella de Carvalho, por sua vez, contou que estava na casa do seu senhor quando o soldado do Primeiro Regimento, Romão Pinheiro, foi procurá-lo para comunicar que ele:

"[...] e outros muitos [tinham] determinado fazer hum insulto [...] com o qual ficaria muita gente felix, e porque hum dos Chefes desta acção he Luiz Gonzaga que estâ prezo [e] he preciso adiantar este particular, antes que o dito Gonzaga declare as pessoas, que nelle estão metidas, parte das quais vivem atemorizadas depois daquelle prizão; e por isso andamos convocando alguns sujeitos de capacidade para a dita acção [reunião no campo do Dique do Desterro] em que podia ser felix, sendo alias cativo [...] $]^{\text {, } 626}$.

O escravo disse que era melhor que o soldado se retirasse e não o viesse atacar com um convite como aquele, afirmando, por fim, que depois que ele tinha visto algumas pessoas presas por intentarem um levante, entre as quais não estava dito Romão, resolveu delatar ao seu senhor tudo o que sabia sobre a participação no levante do soldado.

No dia 14 de outubro de 1798, logo após a sua prisão, José Pires, escravo de D. Maria Francisca da Conceição e Aragão, cunhada do Secretário de Estado e Governo do Brasil, José Pires de Carvalho e Albuquerque, foi chamado pelo desembargador Costa e

\footnotetext{
${ }^{625}$ ADCA, p. 738. Cabe ressaltar que Luiz Gonzaga das Virgens afirmou sobre José Felix da Costa, quando perguntado pelo Desembargador Costa Pinto se conhecia o cativo: "Disse que o conhece não pelo nome, mas sim pela pessoa, pelo ver ser escravo de Francisco Vicente Viana".

626 “Testemunha Luis Leal homem pardo escravo de Manoel Joze Villela de Carvalho...", ADCA, pp. 928-929.
} 
Pinto para prestar esclarecimentos sobre Manuel Faustino, então suspeito de ser um dos cabeças da revolta, que também morava na casa de D. Maria Francisco da Conceição e Aragão, por laço de batismo. O desembargador Costa e Pinto perguntou ao cativo se ele conhecia Manuel Faustino e se este o convidara para "algum levantamento que se projectava fazer nesta cidade". José Pires afirmou que conhecia o acusado por morarem na mesma casa, e que talvez por essa razão Manuel Faustino o perguntou se ele " queria ser forro". Ao responder que "sim, lhe replicou o declarante [Manuel Faustino] que se pozesse pronto $^{, 627}$.

O desembargador perguntou, então, se o cativo tinha sido avisado sobre o encontro no Campo do Dique do Desterro, na noite de 25 de agosto do mesmo ano, para se iniciar um "levantamento". José Pires respondeu que "não foi convidado por pessoa alguma, para se achar nessa noite no campo do dique”. Informou que esteve na roça durante o dia, acompanhando sua senhora, e que quando voltaram "serião sete e meia, ahi encontrou a Luís de França Pires, escravo do dito Secretário deste Estado, e que só perguntou ao dito Luís de França onde hirião?" ${ }^{28}$. O desembargador insistiu para que o cativo falasse a verdade, pois Luís de França tinha afirmado que ele, José Pires, também escravo, estava pronto para a reunião no Campo do Dique do Desterro, pois, após o convite que lhe fizera Manuel Faustino sobre ser forro, José Pires “começou a frequentar a caza de Lucas Dantas, onde ascistia as Sessoens, que ai se fazião acerca do mesmo levantamento, e tanto delle sabia [...]"629.

José Pires disse que as informações do escravo do Secretário de Estado, Luís Pires, eram falsas. Afirmou que passava na casa de Lucas Dantas sempre que lá estava Manuel Faustino, pois ele, depois de aceitar o convite para ser forro, ia a tal casa para saber se Manuel Faustino estava pronto, pelo que ele lhe respondia "sim", mas "jamais passasse a dizer-lhe outra alguma couza, e nem o Lucas Dantas; e nem ouviu tratar de materia alguma”. Um mês depois, em 10 de novembro de 1798, os escravos José Pires e Luís de França Pires, junto com os acusados Manuel Faustino e Lucas Dantas, foram chamados para uma acareação, na qual deveriam esclarecer as informações contraditórias de seus depoimentos.

José Pires, cativo de D. Maria da Conceição, iniciou a acareação reafirmando seu depoimento anterior. Manuel Faustino perguntou se ele tinha ouvido falar na voz da

\footnotetext{
${ }^{627}$ ADCA, p. 771.

${ }^{628}$ Idem.

${ }^{629}$ Idem, p. 772.
} 
liberdade e se ele estava pronto para defendê-la, pelo que ele respondeu que sim e nada mais lhe falou o miliciano pardo "em observância da recommendação que lhe fez Lucas Dantas de Amorim Torres para que elle [o cativo] não manifestasse as pessoas do levante”. O Desembargador Costa Pinto perguntou para o então acusado se ele confirmava as informações do escravo José Pires. Manuel Faustino não confirmou as informações e disse que não havia falado em "voz da liberdade" com o cativo, porque desconhecia o "levante" marcado no Dique do Desterro. Disse que apenas perguntou se o cativo queria ser forro porque soube que ele e sua mãe andavam guardando dinheiro para se "libertarem". De acordo com Manuel Faustino, "por isso sempre respondia [José Pires] que estava pronto, porque tinha pronto o dinheiro para a liberdade "630.

$\mathrm{Na}$ acareação entre os escravos, depois que ambos reafirmaram seus conflitantes depoimentos, o desembargador Costa Pinto pediu que eles chegassem a um acordo acerca da reunião marcada no Dique do Desterro na noite do dia 25 de agosto de 1798. A insistência do desembargador, contudo, não funcionou. Luís da França Pires, escravo do Secretário de Estado, insistiu em seu depoimento que José Pires, escravo de D. Maria Conceição, não só sabia da reunião no Dique do Desterro como também disse a Manuel Faustino que participaria ${ }^{631}$.

Sem que se chegasse a um denominador comum nos depoimentos dos dois cativos, o desembargador chamou a depor Manoel José de Vera Cruz, escravo do Secretário de Estado, José Pires de Carvalho e Albuquerque. Manoel José iniciou seu depoimento afirmando que o escravo do mesmo senhor, Luís da França Pires, era alguém "que vivia mal com elle", para, em seguida, negar a acusação do outro cativo de que ele, Manoel José, sabia e aceitara participar do "levante" no Dique do Desterro. Não só negou a participação na dita reunião como também afirmou que nunca tinha conversado com o cativo, do mesmo senhor, nem com ninguém sobre "semelhante matéria",632. Para demonstrar a "má intenção” de Luís da França Pires, Manoel Jose afirmou que depois de preso "publicamente dis ter pesar de não poder meter no levantamento as escravas pardas da caza, a fim de seos senhores ficarem sem quem os sirva, e nem terem quem lhe de agoa para lavarem o rosto"633.

A animosidade entre os cativos, inclusive do mesmo dono, não parou por aí.

\footnotetext{
${ }^{630}$ ADCA, p. 774. Chamo atenção para o termo "liberdade" dito pelo miliciano pardo Manuel Faustino ao comentar sobre a pergunta feita ao cativo José Pires.

${ }^{631}$ Idem.

${ }^{632}$ ADCA, p. 779.

${ }^{633}$ Idem, p. 782.
} 
João Pires, escravo do Secretário de Estado José Pires de Carvalho e Albuquerque, afirmou em depoimento que Luís da França Pires, escravo do mesmo senhor, "tinha estado no campo do dique com outros mais, para fazer revista da gente que havia para o levantamento projectado”. Em seguida, afirmou que dias antes da referida reunião, Luís da França Pires o tinha convidado "para huma função, sem declarar o fim della, $e$ que fora disto não tratou outra couza alguma com o dito Luís da França Pires ",634.

Cosme Damião Pereira Basto, escravo de Joaquim Pereira Bastos, foi chamado a depor porque Luís da França Pires, escravo do Secretário de Estado, e os acusados Lucas Dantas e Manuel Faustino afirmaram em depoimentos que ele, Cosme, mantinha estreita amizade com o então acusado, de tal sorte que ele descobrira "o segredo da revolução”, por ter sido convidado a participar. Desde então, segundo o desembargador Costa Pinto, Cosme Damião passara a frequentar "amiudadas vezes a caza de Lucas Dantas, onde se repetião sessoens, e conferencias a respeito do mesmo levante”. Coagido diante das informações, Cosme Damião inocentou Lucas Dantas e confirmou a estreita amizade com Manuel Faustino, dizendo que "em razão desta he que [Manuel Faustino] o persuadio a que estivesse pronto com sua pessoa e armas para entrar em hum levante para Liberdade, que elle [...] não aceitou apezar das muitas instancias "635.

Todas as acareações feitas entre os cativos foram resultantes do depoimento de Luís de França Pires, escravo do Secretário de Estado e Governo do Brasil, tomado pelo desembargador Costa Pinto, em 29 de agosto de 1798 - quatro dias depois da abortada reunião no Campo do Dique do Desterro. Sem um motivo aparente, o desembargador perguntou se o escravo conhecia João de Deus do Nascimento. Luís de França Pires respondeu que não, pelo que o desembargador pediu que ele falasse a verdade, pois tinha sido visto com João de Deus pelas aves maria no dia da reunião do Campo do Dique. O escravo confirmou que não tinha estreita amizade com o acusado e nada mais foi perguntado. No dia seguinte, Luís de França Pires foi chamado a depor novamente. O escravo iniciou seu depoimento afirmando que "estava pronto a dizer hoje, porquanto hontem tinha faltado a ella [verdade] em razão de persuadir a isso o Soldado Ignácio da Silva Pimentel”, que também estava preso na Relação ${ }^{636}$.

Luís de França Pires afirmou que o soldado Ignácio Pimentel lhe tinha dito para que negasse qualquer pergunta sobre a reunião do Dique do Desterro, porque qualquer

\footnotetext{
${ }^{634}$ ADCA, p. 784.

${ }^{635}$ ADCA, p. 789.

${ }^{636}$ ADCA, pp. 379-380.
} 
réu que não fosse confesso não era punido com a "pena última". O Desembargador perguntou, então, qual o objetivo da reunião. O escravo respondeu que o soldado lhe dissera que "hia ver se podia ser feliz". O escravo não obedeceu ao juramento que tinha feito ao soldado no dia anterior e passou a delatar detalhes dos acontecimentos, contando "que estavão com o dito João de Deus as pessoas seguintes - Ignácio da Silva Pimentel, Soldado, Joaquim Jozé da Veiga, official de ferrador, e Vicente escravo do

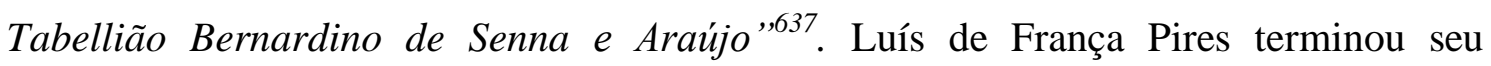
depoimento afirmando que soube da participação das referidas pessoas na reunião porque ia à casa de uma irmã, que ficava perto do local marcado. O escravo disse que, ao voltar, encontrou com Luís Pires, oficial de lavrar prata e ouro com loja no Tabuão, acompanhado de outra pessoa que o escravo não reconheceu. Entretanto, Luís de França Pires afirmou que os dois homens iam se encontrar com João de Deus. No final, afirmou que foi para a casa de sua irmã assustado, porque no caminho encontrou com Alexandre Theotonio "com três negros de pistollas atras, dando sinaes que ainda trazia outra: elle declarante [o escravo Luís de França Pires] assim que ouvio isto logo se retirou, deixando-os $" 638$.

No dia seguinte, o escravo Luís de França Pires foi novamente chamado a depor. Confirmou o depoimento do dia anterior e acrescentou que ao voltar para o segredo da Relação tinha dito ao soldado Ignácio Pires que havia negado tudo "para deste modo conseguir delle algumas noticias mais particulares a respeito do convite do dia vinte e cinco, e dos fins delle" ${ }^{\text {639. }}$. O escravo voltou a depor no dia 17 de setembro do mesmo ano, quando afirmou novamente que não tinha dito a verdade porque seguiu a orientação do soldado Ignácio, e depois quando confessou que tinha estado no campo do dique "se não se lembrou como la fora ter, [mas] que agora mais bem lembrado tem declarado o motivo e cauza da ida a elle: porem que na verdade sempre ignorou o destino e o fim a que se dirigia aquele convite”. O escravo Luís de França Pires terminou o depoimento afirmando que Lucas Dantas, um dos acusados, era "amazio da irma delle declarante [escravo] a parda Francisca, escrava da dita Dona Catharina Correa, e por esta mesma cauza não se comunicava com elle

No dia 1 de outubro de 1798, Luís de França Pires iniciou seu depoimento mais

\footnotetext{
${ }^{637}$ ADCA, p. 381. Chamo a atenção para o fato de que Vicente era o único escravo africano entre os grupo de cativos presos.

${ }_{638}$ ADCA, p. 381.

639 Idem.

${ }^{640}$ ADCA, p. 385.
} 
uma vez afirmando que estava determinado "a dizer toda a verdade, a que tem faltado por temor". Disse que no mês de junho do mesmo ano, Vicente, o escravo do mesmo dono, o Secretário de Estado, dera-lhe um recado de Manuel Faustino para que ele o encontrasse. No encontro Manuel Faustino, um dos acusados, perguntara-lhe se ele "estimava a liberdade e ser forro $?^{641}$ ". O escravo respondeu que sim e contou ao desembargador que Manuel Faustino lhe disse que estava "projectado um levantamento nesta Cidade [Salvador] o qual se executava dahi a hum, ou dous mezes, a fim de serem libertos todos os pretos e pardos cativos e viverem em huma igualdade tal, que não haveria distinção de ceres, e assim vivirião todos contentes".

Luís de França Pires contou que Manuel Faustino pedira que ele usasse uma espada para defender

"o partido do levante, e que a cauza da escravidão em que vivião os pretos e pardos nesta Cidade nascia da Igreja, de quem se devião queixar e que Bonaparte não tardaria aqui [Salvador] quatro mezes a defender com grande armada o partido da liberdade ${ }^{, 642}$.

Logo em seguida, Luís de França Pires denunciou a presença de outros escravos do mesmo senhor que ele, afirmando que Manuel Faustino havia convidado para o "levante" o pardo "Ignacio escravo do dito Secretario deste Estado, irmão de Fortunato da Veiga Manoel Joze, e o carapina João pardos e escravo do mesmo Secretario deste Estado os quais tinhão aceitado o convite, e estavão prontos "643.

O desembargador Costa Pinto perguntou, então, se Manuel Faustino havia convidado a "Manoel Joze, João carapina e Ignacio, escravos do dito Secretário deste Estado", pelo que o escravo Luís de França Pires esclareceu que havia acompanhado João de Deus do Nascimento ao Campo do Dique do Desterro e quando lá chegou encontrou "o pardo Joze de alcunha Tubias, escravo de Dona Maria, cunhada do mesmo Secretario", como também soubera que "Manoel Faustino declarou ter convidado aos sobreditos [escravos do Secretário] $e$ [...] tinhão aceitado o convite ${ }^{\text {"644 }}$. Perguntado se ele sabia da participação de Fortunato da Veiga, o escravo Luís de França Pires respondeu que não sabia, mas que o vira com muita "particularidade" na casa de Lucas Dantas, juntamente com Manuel Faustino e o pardo Ignácio, escravo do

\footnotetext{
${ }^{641}$ ADCA, p. 386. Chamo a atenção para os termos da pergunta feita ao escravo.

${ }^{642}$ Idem.

${ }^{643}$ Ibidem.

${ }^{644}$ ADCA, p. 388.
} 
Secretário de Estado, participando de muita "comunicação", na qual tinha um "credo, feito a cerca da liberdade, que sempre repetia [Fortunato da Veiga], e elle declarante [Luís de França Pires] o prezenciava, e ser o princípio delle - Creio no grande Bonaparte",645.

Como se viu, o escravo, Luís de França Pires, do Secretário de Estado e Governo do Brasil, José Pires de Carvalho e Albuquerque, forneceu um dos mais importantes depoimentos ao desembargador Costa Pinto do Tribunal da Relação da Bahia, durante o ano de 1798. Depois de contar que tentaria manipular o soldado Ignácio, preso na Relação, Luís de França contou detalhes a respeito da reunião do Campo do Dique do Desterro, confirmou a culpa de Lucas Dantas e Manuel Faustino e delatou a participação de outros escravos, do dito Secretário, em reuniões nas quais davam vivas à Bonaparte. Parece inegável que o escravo Luís de França Pires teve uma participação importante nos encontros que ocorriam na casa do Secretário de Estado e Governo do Brasil, José Pires de Carvalho e Albuquerque, que antecederam a revolta de 1798, uma vez que sabia de detalhes do que se passara nos meses que antecederam as prisões.

Depois, comparando o teor dos testemunhos dos demais escravos com os dois que formularam culpa sobre a participação de Luiz Gonzaga das Virgens no levante, José Felix e Luís Leal, há algumas diferenças. Ocorre que coagidos pelos depoimentos de seus proprietários, tudo leva a crer que os dois escravos foram induzidos a ressaltar a participação de homens mulatos e pardos livres, sob a liderança de Luiz Gonzaga, e negar a presença de cativos. Entretanto, as informações de José Felix dando conta de que os negociantes por vezes ficavam na miséria, quando as mercadorias saíam no comboio, comprovam que as razões que motivaram as ações dos partícipes eram muito mais amplas, social e economicamente, do que o poder local relatava para a metrópole. De fato, o escravo tinha razão ao sugerir o descontentamento dos negociantes, pois naquele mesmo ano, ciente do lucro que a exportação do tabaco significava ao Erário Régio $^{646}$, os agentes metropolitanos quase que duplicaram a tributação do tabaco, fazendo com que alguns "principais" da cidade de Salvador, entre eles alguns proprietários de escravos aqui citados, ficassem insatisfeitos. Talvez não seja por acaso que no pasquim $9^{\circ}$, intitulado "Aviso ao clero e ao povo bahiense indouto", há

\footnotetext{
${ }^{645}$ ADCA, p. 389.

${ }^{646}$ AHU_CU_CA_Baía, doc. 18375 - Mappa da exportação dos productos da Capitania da Bahia para o Reino e outros portos do Brasil e África no anno de 1798. Gêneros exportados: assucar, aguardente de mel, algodão, arroz, cacao, couros em cabello, café, cordas de piassaba, farinha de mandiaoca, gomma, ipicacuanha, madeiras, sal, sola, tabaco, e varas para parreiras. Valor total da exportação em 1798: 3.114: $457 \$ 360$. Cabe ressaltar que o tabaco ocupa algo em torno de $20 \%$ do total.
} 
referência à abertura dos portos e ao progresso do comércio:

"[...] Portanto fas saber e da ao prelo que se axão as medidas tomadas para o socorro Estrangeiro, e progresso do Comercio de Açúcar, Tabaco e pau brazil e todos os mais gêneros de negocio e mais viveres; com tanto que aqui virão todos os Estrangeiros tendo porto aberto, mormente a Nação Franceza $[\ldots]^{, 647}$.

Parece estranho que tais questões estivessem no horizonte dos escravos e aparecessem nos depoimentos, exceto pelo fato de que, como se viu nos depoimentos dos cativos, eles escutaram e presenciaram conversas que diziam respeito a uma revolução, nos termos das autoridades locais, e um levante ou "levantamento", nos termos do escravo Luís de França Pires. A questão é que enquanto as autoridades referiam-se à revolução em vários momentos dos depoimentos dos cativos e dos acusados, novamente o escravo Luís de França Pires esclareceu a questão, quando denunciou que os convites aos cativos para participarem de um "levantamento" eram feitos nos seguintes termos: "estimava a liberdade e ser forro?",648. Neste particular, pode-se afirmar que os termos dos convites feitos aos escravos com o objetivo de armálos para o levante é uma estratégia bastante significativa dos homens livres e pobres, nomeadamente João de Deus do Nascimento, Manuel Faustino e Lucas Dantas - talvez, por essa razão, as autoridades locais insistentemente tenham se referido à Conjuração Baiana de 1798, durante os depoimentos dos cativos, como uma revolução.

Com efeito, a discussão sobre a miragem de liberdade econômica é uma chave de entendimento que muito provavelmente apenas os negociantes e senhores de escravos faziam em suas conversas e reuniões, pois tudo leva a crer que os escravos João Felix e Luís Leal comentaram essas questões em seus depoimentos como uma forma sutil de denunciar a participação de seus senhores em reuniões que discutiam não só os acontecimentos da França revolucionária como a tributação da Coroa portuguesa. Se não se averiguaram as informações fornecidas pelos cativos, assim como as autoridades fizeram com as informações do escravo Luís de França Pires, foi porque o poder local não quis, pois tinha conhecimento de que tanto os boletins manuscritos quanto a reunião no Campo do Dique do Desterro eram a ponta de um problema muito mais profundo.

Percebe-se, assim, que o padrão presente no interrogatório dos escravos é o

\footnotetext{
${ }^{647}$ APUD, Kátia M. de Queirós Mattoso. Op. cit., p.155. Grifo meu.

${ }^{648}$ ADCA, p. 386.
} 
mesmo dos depoimentos e da acareação de Domingos da Silva Lisboa, homem pardo. Encerravam-se as perguntas no momento em que os nomes dos "principais" eram citados e retomava-se o processo em um ou dois dias depois, sem que se verificasse a procedência das informações. Entretanto, as informações sobre a participação dos principais, em reuniões de conteúdo sedicioso, chegavam ao conhecimento das autoridades metropolitanas por várias denúncias. D. Rodrigo de Sousa Coutinho, a propósito de algumas denúncias que recebera em maio ${ }^{649}$ daquele ano de 1798 , encaminhou um ofício a d. Fernando, em 4 de outubro de 1798, no qual afirma que em Lisboa:

"[...] depois que chegou o último comboio, se espalharam vozes que dão grande cuidado e que denunciam que as pessoas principais dessa cidade [Salvador], por uma loucura incompreensível e por não entenderam os seus interesses, se acham infectas dos abomináveis princípios franceses e com grande afeição à absurda pretendida constituição francesa, que varia a cada seis meses

As ideias de francezia, nomeadamente as que d. Rodrigo de Sousa Coutinho chamou de "abomináveis princípios franceses", foram um grande problema para a monarquia portuguesa e foram a pauta de boa parte das cartas trocadas entre os agentes régios durante os últimos anos do século XVIII. Em resposta a d. Rodrigo de Sousa Coutinho, um mês antes da publicização dos boletins manuscritos, em 17 de junho de 1798, o governador afirma que as denúncias eram infundadas, mas mesmo assim:

“[...] supostas as circumstancias do século e lição dos papeis públicos, como por exemplo, correios da Europa, gazetas inglezas, que não são prohibidos e outros que excitão a curiosodade, em que se descrevem os successos do mundo com reflexões bastante livres, haja como acontece em toda a parte, huma ou outra pessoa, especialmente entre a mocidade, menos cordata e leve de entendimento, que discorra com mais alguma liberdade sobre os acontecimentos da Europa, nem por isso se tem aqui [Bahia] introduzido princípios jacobinos, nem espécie de sociedade ou ajuntamentos perniciosos $[\ldots]^{, 651}$.

\footnotetext{
${ }^{649}$ Cabe ressaltar que os pasquins sediciosos foram afixados em locais públicos da Salvador apenas em agosto de 1798.

${ }^{650}$ APUD, Inácio Accioli de Cerqueira e Silva. Memórias históricas e políticas da Bahia. Op. cit, vol. III, p. 95 , nota 17.

${ }^{651}$ AHU_CU_CA, BAÍA, doc. 18360 - Officio do Governador D. Fernando José de Portugal para D. Rodrigo de Sousa Coutinho, no qual se refere a uma denuncia em que se acusavam certas pessoas de serem jacobinas. Bahia, 17 de junho de 1798.
} 
Muito provavelmente o governador se referiu aos milicianos das tropas urbanas que, segundo as idades dos indiciados nos autos, eram jovens e eram vistos, à época, como um grupo de homens não muito cordatos, segundo Vilhena ${ }^{652}$. Apesar da informação, chamamos atenção para o fato de que 13 dias após a divulgação dos boletins manuscritos nas ruas de Salvador, d. Rodrigo de Sousa Coutinho enviou uma carta a d. Fernando José de Portugal e Castro na qual institui uma campanha "antifrancezia", comunicando que foram tomadas medidas econômicas para aplacar "possíveis" descontentamentos dos "principais" e mandou-se traduzir gazetas para noticiar o terror que ocorria em França:

"Não perdendo sua Majestade de vista meio algum daquelles que directa ou indirectamente tendem a perpetuar o socêgo, $e$ por conseqüência a felicidade dos seus Vassalos, já instruindo-os do mettodo mais econômico e lucrativo de adiantarem e aperfeiçoarem as suas Lavouras e engrossarem os seus ganhos, já fazendo chagas ao seu conhecimento, como agora o Manda praticar, hum Quadro verdadeiro e fiel não só dos motivos que arrojarão a Nação Francesa a hum [corroído] de calamidades, mas dos effeitos necessários dos mesmos motivos e dos excessos, absurdos e attentados a que dissolutamente se tem abandonado. E contando na Real Presença que em Londres se tinha traduzido em Portuguez huma obra em que energicamente se manifestão os princípios e vistas do actual Governo de França. Mandou sua Magestade vir hum certo número de exemplares dos quaes ordena se remettão a $V$. S. os que vão com este officio para que $V$. $S$. procure derramá-los nesse Estado, a fim que a todos os seus habitantes seja constante e notório, que tão odiozos e tão horrendos são os Crimes que tem caracterizado a atroz Revolução Franceza e manchando aquella Nação que até os mesmos Americanos detestão e aborrecem com indignação a péssima doutrina e as máximas mais depravadas ainda daquelle Governo, terror e pérfido",653.

Além das notícias sobre a Revolução Francesa e a Independência das Treze Colônias, cabe lembrar que, no ano de 1798 a revolta dos escravos da colônia francesa de São Domingos estava em curso, fazendo com que as autoridades ficassem sobressaltadas. Se, por um lado, as autoridades baianas desconsideraram as informações que os cativos forneceram sobre seus proprietários, ao longo do processo, subestimando a percepção que eles tinham dos acontecimentos, por outro lado, afirmavam que os

\footnotetext{
${ }^{652}$ Luís dos Santos Vilhena. Recopilação de notícias soteropolitanas e brasílicas. Salvador: Itapuã, 1969. Ler o item sobre as tropas urbanas, vol. 1, p.245 e segs.

${ }^{653}$ BN, Sessão de manuscritos, códice: II - 33, 29, 70. Ofício de D. Rodrigo de Souza Coutinho a D. Fernando José de Portugal. 1798.
} 
cativos podiam ser contagiados pelas ideias de francezia advindas da Europa, via comunicação com os agentes das colônias estrangeiras. Novamente, o depoimento de José Felix é ilustrativo dos termos que os cativos domésticos tiveram daquela conjuntura. Ao mencionar o problema dos negociantes, para as autoridades, como causa para a implantação de um governo republicano, o depoimento do escravo revela uma estratégia de protesto que passou pela circulação e pelo entendimento das ideias libertárias em seu termo, atingindo a manipulação do medo do seu senhor e das autoridades diante dos acontecimentos.

Considerando que a oralidade era o modo pelo qual as pessoas tinham ciência do que ocorria no mundo, não parece exagerado sugerir que os cativos interpretaram as notícias, conferindo significados próprios e instrumentalizando, em alguma medida, ideias libertárias que circulavam ${ }^{654}$. Cabe lembrar que todos os escravos indiciados nos autos sabiam ler e escrever ${ }^{655}$. Além disso, o professor Francisco Moniz Barreto de Aragão foi acusado de traduzir máximas libertárias e recitá-las até que pardos livres e cativos pudessem memorizá-las, daí que as autoridades temiam as comunicações e alertavam para a "necessária circunspeção" na consecução das devassas, pois, caso contrário, segundo d. Fernando:

\section{[...] poderia nascer da sua execução huma desordem não pequena, posto que momentânea, muito mais de reciar em hum Paiz de Conquista de tanta escravatura, e em tal época, de que resultarião talvez assassinos, e roubos, levantando-se a voz da liberdade ${ }^{656}$.}

Concorria também para o temor das autoridades o fato de que os responsáveis pela circulação das ideias de francezia que chegavam aos cativos urbanos, segundo os autos, eram os homens livres. Conviver de perto com os mulatos ou pardos, na condição de milicianos, ou mesmo de colonos livres, aos olhos das autoridades, era um motivo a mais para os cativos buscarem a liberdade. Não parece ser por outra razão que tanto as autoridades locais quanto os senhores de escravos reforçavam, nos depoimentos e testemunhos, a diferença entre cativos e livres, incitando que os primeiros delatassem os

\footnotetext{
${ }^{654}$ Nesse caso, não se trata de influência das ideias revolucionárias, libertárias ou de francezia. Há sugestivas análises que fornecem pistas na direção da circulação, entendimento e significados próprios dessas ideias nas regiões de escravatura. Para o caso da Revolução do Haiti, ler, Michel-Rolph Trouillot, op.cit. Para o caso brasileiro, ler: Flávio dos Santos Gomes. A hidra e os pântanos. São Paulo: Unesp, 2005; e Marcus Joaquim Maciel de Carvalho. Liberdade: rotinas e rupturas do escravismo. Recife, 18221850. Recife: Ed. Universitária da UFPE, 1998. Ler, especialmente, o capítulo 9 Rumores e Rebeliões, pp. 193-212.

${ }^{655}$ Cf. Informações nos termos de prisão dos escravos. ADCA, vol. 2.pp. 1071-1087.

${ }^{656} \mathrm{BN}$, sessão de manuscritos, Carta de 20 de outubro de 1798 .
} 
segundos. João Pires, escravo do secretário de Estado José Pires de Carvalho e Albuquerque, ao ser perguntado sobre o "levantamento projectado" na cidade, respondeu:

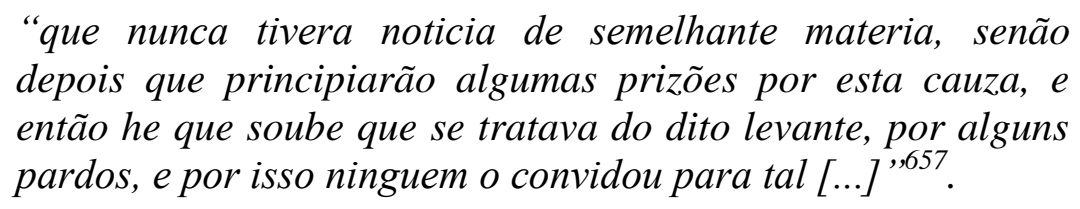

Cabe lembrar que João Pires foi preso porque outro escravo do mesmo senhor, Luís de França Pires, deixara escapar que ambos haviam sido convidados pelo miliciano Manuel Faustino a participar do levante que se realizaria no dia 25 de agosto de 1798. Inocentou-se da culpa ao denunciar Manuel Faustino, homem pardo, e, de quebra, sugeriu que Luís Pires havia "confundido a matéria"658. Aos olhos do cativo urbano, certamente, a condição dos homens livres de cor era melhor do que a deles, ainda que a legislação específica sobre o status do "livre pobre", quando não era discriminatória era silenciosa. Russel-Wood afirma que a situação desses homens era tal que, naquela conjuntura, eles constituíam uma "anomalia legal", o que para Caio Prado, em perspectiva distinta, equivale ao "resíduo inorgânico da sociedade"659.

O fato é que os homens livres e pobres, especialmente os milicianos das tropas urbanas, circulavam muito pelas ruas da cidade baixa e alta de Salvador e por suas cercanias. Pela própria natureza do ofício, os milicianos se sociabilizavam com os escravos de ganho, vadios, mendigos, quitandeiras, estrangeiros que chegavam nos comboios, pequenos e grandes negociantes ${ }^{660}$. Por tudo isso, esses homens foram grandes agentes na circulação das ideias libertárias e de francezia, e assim como os cativos, eles também forneceram significados próprios sobre os acontecimentos.

O soldado Luiz Gonzaga das Virgens foi preso no dia 23 de agosto de 1798 sob a acusação de ter sido ele, e não Domingos da Silva Lisboa, o autor dos pasquins sediciosos. Luiz Gonzaga das Virgens era bem conhecido das autoridades locais. Aos 20 anos, o soldado assentou praça e foi destacado para a companhia de granadeiros do $1^{\circ}$. Regimento de tropa de linha, jurando bandeira a 30 de agosto de 1781 , e teve baixa

\footnotetext{
657 Perguntas feitas a João Pires, homem pardo escravo do Secretario deste Estado Joze Pires de Carvalho e Albuquerque, prezo nas cadeas da Relação. ADCA, vol. II, pp. 783-784.

${ }^{658}$ Idem, p. 784.

${ }^{659}$ Cf. A. J. R. Russel-Wood. Escravos e libertos no Brasil colonial. Rio de Janeiro: Civilização Brasileira, 2005. Essa é a tradução da obra: The back man in slavery and freedom in colonial Brazil. London: MacMillan Press, 1982; Cf. Caio Prado Junior. A formação do Brasil contemporâneo. São Paulo: Brasiliense, 1971, ler, especialmente o capítulo sobre a "vida social".

${ }^{660}$ Cf. Thomas Lindley. Narrativa de uma viagem ao Brasil que terminou com o apresamento de um navio britânico e a prisão do autor. São Paulo: Companhia Editora Nacional, 1969.
} 
como desertor em 30 de outubro do mesmo ano. Jurou bandeira e desertou por mais duas vezes, sendo que depois de 1791 vagou pelos sertões até ser preso e responder processo verbal no Conselho de Guerra, instalado em 9 de abril de $1793^{661}$.

Foi na documentação sobre Luiz Gonzaga, no Conselho de Guerra, que ficava guardada na Secretaria de Estado, aos cuidados de José Pires de Carvalho e Albuquerque, que o desembargador Avellar de Barbedo comparou a letra dos pasquins com algumas petições que o acusado escrevera certa feita. A petição que corroborou para sua condenação informava que:

"sendo os homens pardos recrutados e adscritos ao grêmio Militar das Tropas pagas [...] eram os ditos homens pardos da mesma massa, e sensibilidade dos outros indivíduos albicantes da Sociedade Militar, e Civil, sem maior differença que a da cor, accidente dissimilar com que os distinguio a natureza [...] ficando contudo equivalentes aos brancos, tanto pela substancia Material, como a principal, a espiritual, [entretanto, são tratados] como objectos da escravidão, do desprezo [corroído] e finalmente como exterminados, ou espúrios do mínimo accéso, e graduação dos postos [...], e sem premio, que he só, o que faz gostozos os trabalhos pretéritos $[\ldots]^{,}, 662$.

Luiz Gonzaga finalizou a petição solicitando isonomia para ascensão dos postos mais graduados da carreira militar, alegando que ele era:

"hum individuo da classe dos referidos desgraçados [pardos] tem a magua, magua inconsolável de ver subir aos postos [...] a cor branca, não havendo outros relevantes motivos que [não] differentes merecimentos, e nobiliarchia "663.

Antes da divulgação dos boletins manuscritos, na manhã de 12 de agosto de 1798, Luiz Gonzaga pediu a mercê de "hum anno de licença sem perda de soldo, pão, $e$ seqüentes; para que mais comodamente, em razão da sua pobreza"664. Pedido que lhe foi negado, antes de aparecer preso na Relação. Durante os depoimentos, Luiz Gonzaga forneceu informações importantes sobre o que fizera por ocasião de sua estada no

\footnotetext{
${ }^{661}$ ADCA...vol. 1, p.127 - Concelho de Guerra feito a Luiz Gonzaga das Virgens.

${ }^{662}$ Cf. AAPEB, Maço 581, apenso n. 5, letra L - Comparação da assinatura de Luiz Gonzaga das Virgens no documento do Conselho de Guerra com as petições e requerimentos que ele teria escrito. Esse documento foi incorporado na segunda edição dos Autos das Devassas, de 1998, por ocasião das perguntas feitas a Luiz Gonzaga das Virgens e Veiga. Cf. ADCA, vol. 1, pp. 116-117.

${ }^{663}$ Idem, p. 117.

${ }^{664}$ AHU_CU_Baía_Cx. 96, doc. 18920: Requerimento de Luiz Gonzaga das Virgens e Veiga, no qual pede um anno de licença para tratar no Reino dos seus interesses. Tem anotação de José Luiz de Magalhães e Menezes ao dia 4 de maio de 1798.
} 
sertão. Disse ter conhecido João da Silva Norbona, na cidade de Natal dos Reis Magos, no Rio Grande do Norte ${ }^{665}$. Informou que o dito João era português nascido no Porto, negociante que morava em Salvador e viajava para o Recôncavo a negócios com frequência. Foi perguntado sobre os nomes das pessoas com as quais o dito João mantivera conversas, pelo que Luiz Gonzaga respondeu que "tinha [João] amizade em Caza do Padre Francisco Agostinho Gomes e Jacinto Dias Damasio, e muitos outros homens da Praia, e que em casas destes tomava fazendas para o seu negócio [...]"666.

Perguntado sobre o que eles costumavam conversar, Luiz Gonzaga disse que João da Silva Norbonha era um homem muito instruído e informado dos acontecimentos na Europa, pelo que lia nos jornais, sobre a situação da França e Inglaterra, e que discorria frequentemente sobre a igualdade dos homens e humanidade com que deviam ser tratados, "principalmente sobre a injustiça de nam serem admitidos os pardos a maiores asseços, sem que contudo isso intervisse máxima alguma contra a Igreja ou contra o Estado" ${ }^{, 667}$. As autoridades nada mais perguntaram, retomando o depoimento em outra data e adotando o mesmo padrão dos depoimentos dos escravos e de Domingos da Silva Lisboa.

Os teores das petições e dos depoimentos, das assentadas e das acareações, demonstram que os termos das ideias libertárias e de francezia de Luiz Gonzaga das Virgens significavam, sobretudo, maior inserção na hierarquia militar, da qual ele ocupava o mais baixo posto. A leitura dos textos de d'Anglas, Carra, Volney e o Aviso de São Petersburgo encontrados em sua casa, por sua vez, obtiveram novos significados diante das condições sociais insatisfatórias e tornaram-se reivindicações pontuais. Contudo, parece que, assim como os cativos, tais leituras potencializaram as reivindicações daqueles homens milicianos e tornaram-se ferramentas com as quais eles criam poder mudar suas vidas de alguma maneira. Os cativos e os milicianos que sabiam ler e escrever criam ter condições de reivindicar por seus direitos, uma vez que tais leituras e conversas os tornaram mais sensíveis para a hierarquização da qual eram vítimas. Com efeito, relatar às autoridades locais a participação de homens "colocados entre os povos", na "projetada revolução", não foi uma estratégia apenas dos cativos.

Embora as autoridades locais não averiguassem as informações fornecidas pelos cativos e milicianos, ao longo de mais de um ano de investigação, as denúncias sobre a

\footnotetext{
${ }^{665}$ ADCA, vol. 1, p. 101 - Perguntas feitas a Luiz Gonzaga das Virgens e Veiga, soldado da Companhia de Granadeiros do Primeiro Regimento desta Praça.

666 ADCA, vol. 1, p. 117.

667 ADCA, vol.1, pp. 104-105.
} 
participação de "homens colocados entre os povos" chegaram a Lisboa, e medidas foram tomadas. A esse respeito, a trajetória do padre Francisco Agostinho Gomes, dono de uma das maiores fortunas da época e proprietário da "melhor e a maior livraria particular do Brasil de então composta de milhares de livros ${ }^{668 \%,}$, é significativa da contemporização do poder local face às manifestações dos notáveis baianos envolvidos nos acontecimentos de 1798. O religioso passou de suspeito de participar dos acontecimentos de 1798 a parceiro da Coroa, em uma trajetória para lá de elucidativa do modus operandi da administração local na condução das devassas. Assim como outras pessoas "principais" da sociedade soteropolitana da época, mencionados nos Autos das Devassas $^{669}$, Francisco Agostinho Gomes teve seu nome constantemente citado pelas testemunhas e por diversas vezes fora denunciado por cartas enviadas da Bahia para a Corte entre os anos de 1797 e $1798^{670}$, por ser simpatizante das ideias de francezia.

Como se viu, foi por ocasião dos depoimentos do acusado Luiz Gonzaga das Virgens que o nome do religioso apareceu. Após várias denúncias, o então príncipe regente, d. João VI, solicitou ao governador que se averiguasse com a devida "limpeza de mãos" os fatos. D. Fernando José de Portugal e Castro ordenou a abertura de uma investigação para se descobrir quem era o dito Norbonha e suas relações com o padre. Doze testemunhas foram ouvidas, mas as autoridades não interrogaram nem o padre Francisco Agostinho Gomes nem o negociante e procurador da Câmara de Salvador em Lisboa, Jacinto Dias Damásio, homem citado no depoimento de Luiz Gonzaga das Virgens e testemunha de acusação dos réus da Conjuração Baiana de 1798. Concluiu-se, então, que o tal Norbonha havia sido inventado por Luiz Gonzaga das Virgens para escapar "ardilosamente" das acusações que pesavam sobre ele.

Francisco Agostinho Gomes não devia ser muito bem quisto por algumas pessoas de Salvador, pois as denúncias a respeito de suas atividades e comportamentos não paravam de chegar a Lisboa. A denúncia que irritou profundamente d. Rodrigo de Souza Coutinho dava conta de que o padre tinha por hábito dar jantares em dias santos, sexta-feira da paixão, durante alguns anos: 1796, 1797 e 1798. O ministro mandou que d. Fernando instaurasse uma nova devassa para verificar a procedência de tão "pernicioso" fato. A denúncia sobre o referido jantar é de 4 de outubro de 1798, e a

\footnotetext{
${ }^{668}$ Luís Carlos Villalta. Liberdades imaginárias. In: Adauto Novaes (Org.). O Avesso da Liberdade. São Paulo: Companhia das Letras, 2002, pp. 319-342.

${ }^{669}$ Cf. ADCA, vol. 1.

${ }^{670}$ AHU_CU_BAÍA, docs. 19.117-19.178. Auto da devaça a que se procedeu o Ouvidor Geral do Crime, doutor Manuel de Magalhães Pinto de Avellar e Barbedo, para averiguação dos factos de que era acusado o padre Francisco Agostinho Gomes.
} 
devassa foi instaurada somente no dia 15 de janeiro de $1799^{671}$. O desembargador Manuel de Magalhães Pinto de Avellar de Barbedo, o mesmo das devassas instauradas para se descobrir o autor dos pasquins e fatos conexos com a reunião do Dique do Desterro, ouviu 23 pessoas entre os dias 19 e 23 de janeiro de 1799. Destas, um pardo e vinte e dois brancos, entre os quais: Bernardino de Sena e Araújo, Manuel José Villela de Carvalho e Caetano Maurício Machado - todos proprietários dos escravos que foram entregues à justiça durante a investigação da Conjuração Baiana de 1798.

Das testemunhas ouvidas, 21 pessoas tinham "ouvido dizer" que o dito padre dera um jantar de carne em dia santo. Forneceram detalhes de que os jantares ocorreram durante os sucessivos anos de 1796, 1797 e 1798, no porto da Barra, nas partes de São Pedro e na Praça da Liberdade, e entre os partícipes estivera um grupo de pescadores, muitos dos quais escravos ${ }^{672}$. Chama atenção o depoimento do Bacharel Tomaz da Costa Ferreira, advogado nos Auditórios da Salvador, cuja devassa de residência, como se viu, contou com os testemunhos de alguns dos proprietários dos escravos entregues à justiça durante essas investigações e também testemunharam na devassa de Francisco Agostinho Gomes. Afirmou o desembargador:

"Disse que sabe por ouvir dizer que há dous annos [1797], pouco mais ou menos, em occasião em que aqui [Salvador] se achavão huns certos Francezes arribados que se pretendera dar hum jantar no sítio da Barra, o qual fora impedido por ordem do Illmo. e Exmo. Governador, de forma que não se effectuara $[\ldots]^{, 673}$.

Tudo indica que o governador da capitania da Bahia, d. Fernando José de Portugal e Castro, tinha conhecimento das ações do padre Francisco Agostinho Gomes e do negociante Jacinto Dias Damásio, bem como do teor das conversas nesses encontros, nomeadamente os desdobramentos locais do recrudescimento do conflito entre as nações europeias. Seguindo o padrão de desconsiderar algumas informações obtidas nos depoimentos dos cativos e dos milicianos, o desembargador Avellar de Barbedo encerrou a devassa após três dias.

Não obstante o "ouvir dizer" ter sido mais do que suficiente para a acusação dos

\footnotetext{
${ }^{671}$ Devaça a que se procedeu em conseqüência da acussação feita ao padre Francisco de Agostinho Gomes de ter dado um jantar de carne em sexta-feira da Paixão. A devassa está integralmente publicada, por Braz do Amaral, na obra de Inácio Accioli. Cf. Accioli, op. cit., vol. III, pp. 140-150. Os documentos originais estão em Lisboa, no Arquivo Histórico Ultramarino, no códice Caixas da Bahia, doc. 20.807.

${ }^{672}$ Cf. Luís Henrique Dias Tavares. O desconhecido Francisco Agostinho Gomes. In: Da sedição de 1798 à Revolta de 1824 na Bahia. São Paulo/Bahia: Editora da Unesp/EDFBA, 2003, pp. 125-142; Accioli, op. cit., p. 143.

${ }^{673}$ Accioli, op.cit.
} 
quatro milicianos pardos por participarem de reuniões de conteúdo sedicioso e serem os autores dos boletins manuscritos, com Francisco Agostinho Gomes, ao contrário, o "ouvir dizer" livrou-o das acusações, posto que se "averiguara serem falsos os fatos" 674 . Significativo, nesse sentido, é o argumento utilizado por d. Fernando José de Portugal e Castro com o objetivo de justificar os procedimentos adotados na devassa do padre e o termo a que se chegou, pois a conclusão não agradou algumas pessoas que acusaram o governador de "frouxo". O governador da capitania da Bahia afirmou para d. Rodrigo que a maioria dos governadores estabelecidos na América era:

"[...] despóticos ou frouxos: se castigão de modo extraordinário, sem processos, sem figura de juízo, preteridas as formalidades prescriptas nas Leys e os meyos que ellas tem estabelecido, de devaça, querela, summario de denuncias, merecem o nome de despóticos; se pelo contrario procedem em conformidade com as mesmas Leys, ouvindo-se as partes, perante aquelles magistrados próprios e destinados para conhecerem em geral dos delictos [...], merecem na opinião de algumas pessoas indiscrectas, de espírito maléfico, de que se tem sido desatendidas nas suas queixas e representações, posto que [...] o nome de frouxos, sem se lembrarem que há hum meio termo entre estes dous extremos que é aquelle que eu tenho seguido [...], aquelle que se queixa contra ao Governador de ferimento, roubo, ou outro qualquer dellicto [...] seja encaminhado para o juiz competente pelo mesmo Governador, sem ser ouvido e convencido por mero requerimento do queixoso, ou ainda por huma simples informação que manda tirar do caso",675.

Francisco Agostinho Gomes foi inocentado das acusações que lhe imputaram. Imediatamente após a devassa ${ }^{676}$, o padre viajou para Lisboa para solicitar a concessão do monopólio de exploração de uma mina de ferro e cobre na Serra da Borracha ${ }^{677}$. Francisco Agostinho Gomes foi agraciado com a mercê régia referente à concessão de sesmarias, com o monopólio na exploração das terras em que se descobrissem minérios de ferro e cobre e onde existissem florestas que garantissem suprimento de carvão vegetal. O monopólio foi concedido com "alguns privilégios e isenções de direitos que se fazem necessários para hum tão útil estabelecimento"678.

\footnotetext{
${ }^{674}$ AHU_CU_CA_Baía, doc. 19.177. Officio do Governador D. Fernando José de Portugal para D. Rodrigo de Sousa Coutinho, no qual se refere a uma devassa a que mandara proceder contra o Padre Francisco Agostinho Gomes e pela qual se averiguara serem falsos os factos de que o acussavam. Bahia, 12 de fevereiro de 1799.

${ }^{675}$ Accioli, op.cit., Vol III, p. 133. Documento transcrito integralmente por Braz do Amaral na nota 17.

${ }^{676}$ AHU_CU_Caixas da Bahia, doc. 20.177.

${ }^{677}$ AHU_CU_CA_Baía, doc. 20.459.

${ }^{678}$ Idem.
} 
D. Fernando José de Portugal e Castro, como se viu, limpou as evidências que pesaram sobre o padre Francisco Agostinho Gomes, no ofício de 13 de fevereiro de 1799, sob o argumento de que não havia prova contra o padre, para, simultaneamente, contribuir para que este fosse agraciado pela magnificência da Santíssima Majestade e lhe fosse concedido o prêmio de mercê. Em outro ofício a d. Rodrigo, o governador tentou amenizar a péssima impressão sobre o padre, causada pelas denúncias, e o descreve como alguém de confiança e um "homem sumamente atado, acanhado",679. Se, por um lado, o padre Francisco Agostinho foi inocentado pela acusação de ser sectário dos ideais libertárias e de francezia e premiado por mercê régia, por outro, os quatro homens livres, pobres e pardos foram castigados, pois o governador reafirmou a d. Rodrigo de Sousa Coutinho que dos partícipes da "projetada revolução” de 1798:

"[...] quaze todos pardos, entrando neste numero hum Tenente e hum Inferior do Regimento de Artilharia contra os quaes resultão certos indícios, sem que apareça até agora hum só preto convidado, a excepção do segundo denunciante, ou seja por certa opozição que há entre pardos e pretos, ou por aqueles, alem de serem mais prezumidos e vaidozos, são reputados como mais astutos e sagazes para qualquer empreza ${ }^{680,}$.

Assim, potencializando a animosidade entre cativos e libertos pobres e aproveitando-se de algumas acusações mútuas, nos depoimentos e testemunhos, de participarem da "projectada revolução", como se viu, o poder local não convocou nenhum dos proprietários de escravos a prestar esclarecimentos sobre suas participações em reuniões de conteúdo sedicioso. Eles aparecem para formular culpa sobre as ações sediciosas dos milicianos, como Francisco Vicente Viana e Manuel José Villela de Carvalho. Se o padre Francisco Agostinho Gomes foi devassado em apenas três dias, foi porque as denúncias romperam o circuito das devassas e, portanto, o controle do poder local na condução dos processos, chegando a Lisboa. O procedimento do governador em relação ao padre sugere, ao menos, que era de seu conhecimento o significado da circulação das ideias libertárias e de francezia pelos "principais", pois eles também poderiam instrumentalizá-las para seus interesses.

Considerando que em um dos boletins manuscritos os partícipes reivindicaram a abertura dos portos e a comercialização com a inimiga nação francesa, pode-se asseverar que a instrumentalização das ideias libertárias e de francezia, pelos

\footnotetext{
${ }^{679}$ AHU_CU_Caixas da Bahia, doc. 20.177.

${ }^{680} \mathrm{Idem}$.
} 
"principais", acarretaria maior densidade política ao evento, na lógica do discurso do poder local. Com efeito, a Conjuração Baiana de 1798 deixa de ser um acontecimento apenas de "pardos milicianos faltos de religião e fidelidade", como afirmou o governador a d. Rodrigo de Souza Coutinho, para significar uma ameaça socialmente legitimada, uma vez que as demandas políticas e econômicas dos altos setores da sociedade baiana da época, envolvida no movimento, ameaçou o ponto nevrálgico da dominação portuguesa no Brasil, o exclusivo metropolitano, e as relações daí derivadas.

Não parece ser por outra razão que investigações sobre os autores dos boletins manuscritos e os réus da Conjuração Baiana de 1798 duraram mais de um ano e foram inegavelmente conduzidas pelo governador da capitania da Bahia, d. Fernando José de Portugal e Castro, no sentido de deixar à margem das devassas a participação dos homens da corporação dos enteados, constantemente retratadas nos vários depoimentos dos cativos e dos milicianos acusados, pois:

"[...] o que sempre se receou nas colonias é a escravatura [...] não sendo tão natural que os homens bem empregados $e$ estabelecidos, que têm bens e propriedades, queiram concorrer para uma conspiração ou atentado, de que lhes resultariam péssimas conseqüências " ${ }^{\text {"681. }}$.

D. Rodrigo de Sousa Coutinho, no entanto, alertou d. Fernando José de Portugal e Castro:

“[...] sejão estes Réos sentenciados em Rellação pello merecimento dos autos devendo elles ser julgados com maior promptidão, e com a publicidade que permitem as Leys [...] recebendo o merecido castigo pelos seos crimes, uzando-se com elles de toda a severidade das Leys, tanto a respeito dos Cabeças, como dos que aceitarão o convite; e dos que não denunciarão tal, e enorme Crime, devendo para o futuro constar a todos que em tão grande atentado o bem público, não sofre moderação alguma de pena ordenada pella Ley $[\ldots], 682$

O poder régio ordenou que a punição exemplar fosse aplicada, sem distinção, entre os "cabeças" e os demais partícipes do evento, pois, no limite, criam ser pouco provável que os principais da Salvador fossem "faltos da necessária fidelidade de um vassalo" e consequentemente sectários dos princípios franceses. Nessa lógica, apenas os

\footnotetext{
681 Ibidem.

${ }^{682}$ Cópia da Carta Régia de sua Majestade Fidelíssima, d. Maria I a d. Fernando José de Portugal e Castro. ADCA, vol. 1, pp. 71-72.
} 
populares poderiam compartilhar "dos abomináveis princípios franceses". Em contrapartida, para o poder local, a situação era merecedora de cautela. Face às ordens da Coroa e das informações que os depoentes forneceram ao longo das devassas, d. Fernando José de Portugal e Castro ponderou novamente sobre a necessária distinção na aplicação da pena, uma vez que:

"[...] consta haver varias classes de Réos, huns no numero talvez de quatro ou seis reputados como principaes cabeças desta sedição, outros que posto não fossem os autores prestaram o seu consentimento, e convidarão varias pessoas, outros que aceitarão o convite e assistião aos conventiculos em que alternadamente comparecião, outros que sendo convidados não denunciarão como erão obrigados, e alguns, finalmente, que ainda nem aceitarão o convite antes repugnarão, ou que foram meramente sabedores desta desordem, tiverão a inconsideração de se calarem $e$ guardarem segredo, ou por assentarem que não terião effeito semelhantes projectos revolucionários, ou por ignorância, se he que a podem alegar de faltarem a primeira, e a mais essencial obrigação de hum vassalo, estando por conseqüência incursos huns em pena ordinária e Capital, e outros na de degredo, mais, ou menos grave, por maior ou menor numero de annos, segundo diversos graos de imputação que contra elles houver "683.

No dia 18 de outubro de 1799, foram definidos os critérios para as sentenças e o termo de conclusão da devassa instaurada para averiguar a "projectada revolução". Concluiu-se que alguns habitantes da cidade de Salvador tentaram executar uma sublevação para subtrair o governo de Portugal. Para que se chegasse ao termo da sublevação, as autoridades afirmaram que os partícipes elegeram chefes e cabeças que eram:

"indivíduos das mais baixas [...] classe dos homens pardos, qualidade que lhes era odioza pretendendo por isso extinguila por meio da indistincta igualdade a que aspiravão [...] fasendo disseminar ideas Livres e sentimentos antipoliticos entre aquelles que suppunhão mais capazes e dispostos à segui-los [...] as imaginarias vantagens, e prosperidades d'huma Republica Democrática, onde todos serião Communs sem diferença da cor e nem da condição, onde elles occuparião os primeiros Ministérios, vivendo debaixo d'huma geral abundância, e contentamento [...] "684.

O relato minucioso do termo de conclusão demonstra que "inculcando ao mesmo

\footnotetext{
${ }^{683}$ Carta de d. Fernando José de Portugal a d. Rodrigo de Souza Coutinho. BN, Sessão de manuscritos.

${ }^{684}$ ADCA, vol. II, pp. 1122-1123.
} 
tempo de sabedores, e interessados na sua execução [convidaram] pessoas de tal preheminencia, autoridade, e honra, que estas mesmas qualidades as excluem do mais leve pensamento de infidelidade", e, após um ano, em que "machinavão a oculta conspiração", foram achados em ruas, templos e igrejas "vários pasquins, os mais ímpios, atrevidos e sediciozos, que podia abortar húa imaginação esquentada e destituída de lume da Religião, e respeito devido ao Sumo Imperante” que resultou na captura de um "monstro de maldades" "685. Após a primeira prisão, os desembargadores concluíram que o encontro do dia 25 de agosto no Campo do Dique do Desterro ocorrera porque após as declarações do então acusado, os partícipes por:
"receo de serem descubertos pelas Confissoens, $e$ declaracoens do seu Sócio e Amigo [Luiz Gonzaga das Virgens] e considerando-se em húa Crize arriscadas, $e$ perigoza, tomarão o partido de desenvolver todo o fel dos seus projectos, procurando os meios de os adiantar, e reduzir a effectiva execução" $[\ldots]^{686}$.

Concluiu-se que os culpados de crime de lesa-majestade, por conspirarem contra a Coroa portuguesa, ao projetarem um levante no Campo do Dique do Desterro, foram:

"os infelices, e desgraçados RR [réus] Lucas Dantas de Amorim, João de Deos do Nascimento, Manoel Faustino dos Santos Lira, Romão Pinheiro e o auzente Luis Pires Condemnados a morte pelo Respeitável Acórdão [em branco], assim como também o Tenente do 2. Regimento de Linha desta Praça Hermógenes Francisco de Aguillar Condemnado em hum anno de prizão, e os RR [réus] Manoel Jose da Vera Crus e Ignácio Pires condemnados em 500 açoutes, e vendidos para fora da Capitania [...] ${ }^{\text {,687 }}$.

Luiz Gonzaga das Virgens, por sua vez, foi o único condenado pela autoria dos boletins manuscritos, afixados nas ruas da Salvador na manhã de 12 de agosto de 1798, pois se concluiu que Domingos da Silva Lisboa não poderia ser autor dos papéis, de acordo com o termo de conclusão datado de 7 de novembro de 1799:

"Justiça que a Rainha Nossa Senhora manda fazer a este
execrável reo Luiz Gonzaga das Virgens, homem pardo,
natural desta Cidade [Salvador], a que com baraço, e pregão
seja levado ate o lugar da forca, erigida para este supplicio, e
que nella morra morte natural para sempre sendo-lhe depois
de morto separadas as mãos, e cortada a cabeça, que ficarão
postadas no dito lugar da execução, ate que o tempo as

\footnotetext{
${ }^{685}$ Idem.

${ }^{686}$ Idem, p. 1124.

${ }^{687}$ Idem, p. 1144.
} 
consuma, no que foi condenado, e na confiscação de seos bens para o Fisco, e Câmara Real, e nas custas por Acórdão da Relação que outrosim declarou infame sua memória, de seos filhos e netos, mandando outrosim que sendo propria a caza de sua habitação, seja demolida, Salgada para nunca mais se edificar $[\ldots]$, 688 .

Quanto aos escravos José Felix da Costa e Luís Leal, que formularam culpa na devassa de Luiz Gonzaga das Virgens e depois foram indiciados na devassa para averiguação da "projectada revolução", o primeiro foi degredado para as regiões da África fora dos domínios de Portugal; e o segundo foi inocentado por ser "absolutamente isento de qualquer culpa" $" 689$. Os escravos do secretário de Estado e Governo do Brasil, José Pires de Carvalho e Albuquerque, por sua vez, tiveram suas penas aliviadas, pois foram culpados "pella falta de delatação do crime projectado, tendo delle noticia, a sua ignorância os contistue na necessidade de merecerem o alivio referido. Sendo escravos elles não podião saber da obrigação de delatarem[...]"690.

O professor Francisco Moniz Barreto de Aragão foi condenado à pena de degredo por ser sectário das ideias de francezia, mas teve sua pena comutada depois que apresentou certidões que comprovaram sua nobiliarquia. $\mathrm{O}$ termo final de sua sentença foi assim definido:

\begin{abstract}
"outrosim commutão as penas impostas ao Reo Francisco de Aragão em hum anno de prizão tão somente na Cadea publica desta Cidade, e na privação da Cadeira, que tem exercido, $e$ inhabilidade para ministério de ensino publico, visto tambem que se não manifesta com a preciza concludencia, que elle commonicasse, e denominasse as sediciozas décimas, que lhe forão achadas, ou, fizesse applicação da sua detestável doutrina ${ }^{, 691}$.
\end{abstract}

Quanto aos "abomináveis princípios franceses" que tanto preocupavam os agentes metropolitanos, os desembargadores do Tribunal da Relação concluíram que apenas os homens pardos eram sectários dos "perniciosos princípios", pois, após as investigações, as denúncias que davam conta de que algumas pessoas importantes também aprovavam a doutrina não procediam. Eram "arroubos intelectuais de rapaziada impossíveis de atalhar, pois não somente os impressos em que se baseavam

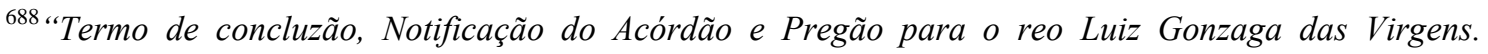
ADCA, vol. 1, pp. 175-176.

${ }^{689}$ ADCA., vol.2, p. 1191.

${ }^{690}$ ADCA, vol.2, p. 1161.

${ }^{691}$ ADCA, vol. 2, p. 1191.
} 
eram de controle difícil e circulavam livremente"692. Para que não houvesse nenhuma dúvida a respeito, e para encerrar definitivamente a questão, o governador da capitania da Bahia astutamente relembrou d. Rodrigo sobre um ofício, no qual o próprio Ministro ordenava que se espalhasse no Brasil uma obra traduzida para o Português, noticiando os malefícios da doutrina de francezia, acrescentando que:

"[...] contudo he-me summamente sensivel que se considere por quem quer que seja como huma das causas de hum facto que se não verificou, a frouxidão deste Governo, como se eu devesse proceder inconsideradamente, sem denúncias, sem provas, sem indícios, em matéria de tanto melindre $e$ gravidade contra o sobredito Padre ou contra outro qualquer, só porque lê correios da Europa, Gazetas inglezas que são remettidos dessa Côrte a differentes pessoas"

${ }^{692}$ In: Accioli, op. cit., vol. III, p. 133 


\subsection{As negociações em 1799}

O ano de 1799 foi decisivo para os rumos do Império Português. Foi o ano em que os réus da Conjuração Baiana de 1798 foram enforcados e esquartejados na Praça da Piedade em Salvador. Segundo frei José do Monte Carmelo, carmelita descalço ${ }^{693}$ e prior do Convento e Igreja de Santa Teresa, Manuel Faustino, depois de ser preso no segredo da Relação, tentou se suicidar várias vezes por influência nefasta do demônio. Como o réu foi livrado da morte todas as vezes, ele se voltou à mãe de Deus porque a "malícia ainda não tinha lançado raízes fundas no seu coração", passando seus últimos dias de vida rezando de dia e de noite ${ }^{694}$. No entanto, no dia 5 de novembro de 1799 , após "todos os delinquentes" 695 terem sido chamados para ouvirem as sentenças que os condenariam à morte, Manuel Faustino e os outros condenados voltaram para o segredo da Relação para que fossem ouvidos em confissão pelo frei José do Monte Carmelo antes de serem executados em praça pública.

Após relutar por sentir "uma repugnância em ir pessoalmente, tanto contra o q" eu achava em mim para com outros em semelhantes ocazioens, q'e me obrigavao' a usar algumas pessoas", frei José chegou à noite no oratório da Relação para começar as confissões. O carmelita relata minuciosamente que assim como Manuel Faustino, com os outros condenados "teve o Demônio ocaziao" de lhes sugerirem o pensamento do suicídio, mas como Deus desejava salvá-los, frei José passou então a descrever o arrependimento dos "condenados delinqüentes", ressaltando o milagre da Misericórdia divina no momento de suas conversões.

\footnotetext{
${ }^{693}$ A ordem dos Carmelitas surgiu no final do século XI, na região de Monte Carmelo, na Palestina. A partir do século XVI, já no Ocidente, especificamente na Espanha, os Carmelitas passaram por um movimento de renovação com Santa Tereza D'Ávila e São João da Cruz. A ordem foi dividida em Carmelitas Calçados, que seguiam a ordem antiga, e os Carmelitas Descalços seguidores do movimento renovador. A ordem chegou ao Brasil em 1580 e estabeleceu-se em Pernambuco, onde fundou o Convento do Carmo de Olinda, em 1583. Estabeleceram-se na cidade de Salvador, em 1586, onde fundaram seu segundo convento. A esse respeito ler: Eduardo Hoornaert. História da Igreja no Brasil. Petrópolis: Vozes, 4a . edição, 1992; Waldemar Mattos. Os Carmelitas Descalços na Bahia. Salvador: Manú, 1964. Luís dos Santos Vilhena, entretanto, afirma que os Carmelitas Descalços fundaram seu mosteiro na Bahia em 1665. Cf. Vilhena, op.cit., vol. 2, p. 446.

${ }^{694}$ Outra relação feita pelo P. Fr. Joze D'Monte Carmelo, religiozo carmelita descalço. Instituto Histórico e Geográfico Brasileiro, Notícia da Bahia, tomo IV, Lata 402, manuscrito 69. Arquivo Histórico Ultramarino, inventário Castro e Almeida, Bahia, documentos avulsos, caixas: 41 a 82 . O documento "Outra relação ..." está integralmente transcrito na obra de Luís Henrique Dias Tavares. História da Sedição intentada na Bahia em 1798 (A Conspiração dos Alfaiates). São Paulo/Brasília: Pioneira/INL, 1975, pp. 123-137, passim.

${ }^{695}$ Idem, p. 125.
} 
Manuel Faustino, segundo o carmelita descalço, pediu-lhe perdão por seus atos como forma de arrependimento, chegando, inclusive, a ser "Pregador para a conversao' de seus companheiros impenitentes". Frei José nos conta que foi a cena mais "terna ver este mancebo" chegando perto de João de Deus do Nascimento e lhe dizer "Joao' de $D^{o}$ convertete, e confeçate, olha q' ja nao' temos remedio, apenas nos faltao' 7 oras de vida, e nao' queiras perderte; olha $q^{\prime}$ disgosto será $p^{a}$ tua mulher, teos filhos, $e$ parentes, se morreres impeniten[te $]^{696 \% "}$.

Lucas Dantas, segundo frei José, mereceu o empenho da Misericórdia divina para o "fazer feliz quanto elle trabalhou para ser eternamente desgraçado, porem como Deus ja' previa ser elle, entre tantos culpados, um dos 4 desvalidos dos omens, e conduzido ao suplicio, quis muito antes defendelo de todas as desgraças, q' contra si mesmo intentava até o conduzir salvo à sua glória”. Não por acaso, o carmelita descalço novamente carrega na tinta o arrependimento de Lucas Dantas no segredo da Relação e, depois, em praça pública, afirmando que este, assim que subiu ao patíbulo, falou a "todo o povo; e pedio perdao' dos seus escandalos, [pediu] auxilio de Deos, e o amparo de sua May Santissima, levantou os olhos ao Céo e dali sentio baixar aquella mizericordia ${ }^{697, "}$

Ao narrar o arrependimento dos condenados Manuel Faustino e Lucas Dantas como o milagre da Misericórdia divina, frei José afirma que sua intenção era demonstrar aos homens que com "estes dous pobres desvalidos, quis $D$ [eos] mostrar a todos as Luzes potentes $q^{\prime}$ as suas vistas estao' fixas nos pequeninos, e q' favorece como Pai aos q' o mundo desprésa”. Em seguida, o carmelita descalço procurou demonstrar as "novas maravilhas nos outros dous Joao' de Deos, e Luiz Gonzaga”, para que os homens soubessem que os milagres e prodígios “nao' estao' anexos aos tempos "698.

Frei José nos conta que João de Deus e Luiz Gonzaga entraram no Oratório fingindo que perderam o juízo, parecendo uns loucos, de acordo com a junta de médicos que foi chamada para examiná-los. Segundo o carmelita descalço, como os réus insistiam em dar mostras de loucura e perda da razão, "tratamos fortemente de os converter, chegando a se juntar no Oratório até o número de vinte, e tantos Religiozos

\footnotetext{
${ }^{696}$ Idem, p. 127.

${ }^{697}$ Idem, p. 130.

698 Ibidem.
} 
de todas as Religioens desta Cidade e Presbiteros Seculares; porem nada se pôde conseguir" $" 699$.

Não obstante o número de religiosos chamados a "salvar" os réus, segundo frei José, a conversão dos réus só foi possível porque "a graça $q^{\prime}$ os havia converter, se guardava para aquelle instante no qual todos fossem testemunhas do seu poder, $q^{\prime}$ nao' sao' os omens, com seus discursos quem convertia aos outros omens, se nao' Deos com a sua graça". De maneira distinta do relato acerca dos primeiros réus no qual o carmelita descalço demonstra o arrependimento e a conversão destes na Relação e depois no espaço da praça pública, frei José justifica o fracasso no processo de conversão de João de Deus e Luiz Gonzaga no espaço privado do segredo da Relação, conferindo uma dimensão política aos desígnios de Deus e, no limite, à religião, afirmando que 'farao' ultimamente conduzidos impenitentes ao patíbulo fazendo se sensível a toda a Cidade tal desgraça para $q^{\prime}$ depois fosse a todos os omens a mizericórdia mais notável ${ }^{, 700}$.

Assim, na manhã quente de 8 de novembro de 1799, segundo o frei, as tropas de linha ocuparam desde cedo a Praça da Liberdade, amplo quadrilátero localizado no centro de Salvador. O povo curioso não parava de chegar. Estabeleceu-se um cordão de isolamento entre a tropa e o patíbulo público construído especialmente para a ocasião. Pelas onze horas, iniciou-se a procissão. À frente, banda de cornetas e tambores, seguida das irmandades revestidas das suas opas e capas, de cruz alçada e com seus respectivos vigários. Logo após, os condenados a degredo caminhavam de mãos atadas às costas, precedidos do porteiro do Conselho, com as insígnias do seu cargo, seguido dos quatro réus condenados à pena capital pelo crime de lesa-majestade de primeira cabeça, acompanhados de dois frades franciscanos, além de todos os escrivães, meirinhos e o porteiro do Tribunal da Relação da Bahia. Seguiam-nos empunhando a bandeira de Portugal o Senado da Câmara, os vereadores, os alcaide-mores e mirins, e o procurador do Conselho. Mais atrás, a irmandade da Misericórdia e o carrasco, ostentando as insígnias de seu ofício.

As gentes iam lotando as janelas das casas para ver a procissão dos condenados. O cortejo percorreu as ruas da Sé, desde o Terreiro de Jesus até o cimo da ladeira do Tira Preguiça, chegando à Piedade. Após o rufar dos tambores, o meirinho-mor leu pela última vez os pregões reais que anunciavam a morbidez com a qual os acusados seriam

\footnotetext{
${ }^{699}$ Idem, p. 131.

${ }^{700}$ Ibidem.
} 
punidos por serem considerados pelas autoridades régias os cabeças da "projectada revolução" que instituiria um governo democrático no Brasil. Diante dos três regimentos pagos daquela praça, postos em armas para prevenir qualquer acidente que pudesse originar em favor dos réus, os condenados subiram ao cadafalso.

O primeiro a ser enforcado foi Luiz Gonzaga das Virgens e Veiga. Antes, segundo o carmelita descalço, o réu o chamou para um "ato de protestação", arrependendo-se de seus atos, especialmente por ter desrespeitado a Igreja. A "admiração que cauzou a todos o q' dice Gonzaga foi singular",701. Afirma o carmelita que Luiz Gonzaga disse para todos ouvirem "eu confeço, q'este Pai piedozo [...] derramou não só por elles, mas também por muitos o seu sangue para me salvar; neste espero o meu remédio [...]". Continuou sua confissão pública queixando-se do dano que lhe causaram as más companhias, aconselhando a todas as gentes a fugirem delas, e pediu perdão por não ter seguido os virtuosos conselhos que sua madrinha lhe dera ${ }^{702}$. Terminou fazendo as mais “ternas súplicas a Deus para q’ se dignasse salvalo”. Após a confissão, foi enforcado em meio à comoção das gentes diante de suas exclamações.

Chorando muito após presenciar o enforcamento de Luiz Gonzaga das Virgens e Veiga, João de Deus do Nascimento pede que frei José se aproxime para “um fervoroso ato de contrição" ${ }^{\text {703 }}$. Segundo o carmelita descalço, minutos antes de ser enforcado, João de Deus despediu-se da vida dizendo ao "inumerável povo que se encontrava naquela praça" que:

'Sigao' a ley [do] verdadeiro Deos, a Religiao' Catolica he, a so e única verdadeira, e tudo o mais he engano; quando eu a seguia sem duvida alguma vivia e nao' (sic) bem ainda q'pobre, talvez independente, porem depois q'eu dei ouvidos a uns cadernos, a um Voltaire, a um Calvino, a um Rousseau, deixei o q'nao' devera e por isso vim parar a este lugar. Senhores quem quizer ser mau seja so para si, e nao'

\footnotetext{
${ }^{701}$ Idem, p. 134.

${ }^{702} \mathrm{O}$ nome da madrinha de Luiz Gonzaga das Virgens e Veiga permanece desconhecido. Sabe-se, no entanto, que ela era esposa de Pedro Nolasco de Sã Marinho de Azevedo, senhor do engenho São Cosme Damião, à época, termo da vila de Santo Amaro da Purificação. No testemunho realizado em 28 de agosto de 1798, Pedro Nolasco confirmou ser de Luiz Gonzaga as letras dos pasquins sediciosas e afirmou ao desembargador Avellar de Barbedo que "dava de comer [a Luiz Gonzaga] por caridade, por ter sido afilhado da defunta sua mulher”. Cf. Assentadas, pp. 43-44, vol. I. In: Autos da Devassa da Conspiração dos Alfaiates. Salvador: Arquivo Público do Estado da Bahia, 1998. Doravante: ADCA. Sobre Luiz Gonzaga das Virgens, ler Luís Henrique Dias Tavares. O soldado Luís Gonzaga das Virgens. In: Da Sedição de 1798 à Revolta de 1824 na Bahia. Editora da Unesp/ EDUFBA: São Paulo/Salvador, 2003, pp. 55-84.

${ }^{703}$ Luís Henrique Dias Tavares, op.cit., p. 135.
} 
convoque os mais. [...] Liberdade e igualdade he isto apontando $p^{a}$. a forca, ${ }^{, 704}$.

Ainda de acordo com o frei:

“[...] dizia João de Deus a todos q' o ouviao' e sendo chegado o último momento de sua vida, e emplorando de Deus misericórdia, e pedindo socorro dos Sacerdotes; pedio também ao algoz q' lhe desse uma boa morte. Então' antes que caísse do patíbulo, agitandosse até morrer, e gritando por Jesus Maria, chaio ultimamente do patíbulo, acabando a ultima de suas palavras na vida dizendo: misericórdia, misericórdia... ${ }^{705 ", .}$

À execução dos outros dois réus seguiu-se o esquartejamento dos corpos. A cabeça de Lucas Dantas foi degolada, assim como as dos outros três, e depois espetada em um poste no Dique do Desterro. Os outros pedaços dos corpos dos réus foram expostos no caminho do Largo de São Francisco, onde Lucas Dantas residiu. Em frente ao mesmo local, foi colocada a cabeça de Manuel Faustino dos Santos Lira, por ser ele frequentador assíduo daquela residência e por não ter endereço fixo. A cabeça de João de Deus foi exposta na rua Direita do Palácio, atual rua Chile. Suas pernas, seus braços e seu tronco foram espalhados pelas ruas do Comércio, local de grande movimento da Cidade Baixa. No patíbulo, ficaram espetadas as cabeças e as mãos de Luiz Gonzaga, por ter sido considerado pelas autoridades régias o responsável pelos pasquins que anunciaram à população a "projectada revolução ",706.

No dia seguinte ao mórbido espetáculo, os corpos expostos ao calor davam sinais de rápida decomposição e atraíam uma revoada de urubus que enchiam a cidade de emanações pestilentas. No dia 11 de novembro de 1799, o ar da cidade era irrespirável, a podridão invadira todas as casas e a população temia por sua saúde. Diante do precário estado sanitário da cidade, algumas autoridades e irmãos da Misericórdia intervieram junto ao governador d. Fernando José de Portugal e Castro, solicitando a retirada dos corpos mortos e expostos a mando da justiça para o exemplo dos povos. O pedido foi deferido na madrugada do dia 15. Os despojos foram recolhidos pelas autoridades e enterrados em local até hoje desconhecido.

Como quase todos os condenados em seus momentos finais de vida clamaram perdão à Virgem Maria, o religioso cria que o seu relato perpetuaria na memória do

\footnotetext{
${ }^{704}$ Ibidem. Grifo meu.

705 Outra Relação ...

${ }^{706}$ Idem.
} 
povo o prodígio dos desvalidos condenados e a misericórdia divina que, em terra, os homens não foram capazes de lhes conceder. Entretanto, no final da narrativa, frei José questiona a pena imputada aos quatro réus, afirmando que o milagre da misericórdia divina só foi possível porque Deus, que tudo vê, sabia que os quatro homens enforcados em praça pública não foram os únicos que cometeram o delito régio, "provando se lhes como diz a Sentença de terem sido cabeças de uma sublevação q' nesta mesma Cidade se intentara"707. Assim, “depois q' forão justiçados os ditos padecentes; aos quaes assisti dentro do Oratório de dia, e de noite...", o carmelita descalço afirma finalmente:

“ao segundo q' eu tenho como de Fé, q'sendo tantos os culpados no mesmo delito, e q' se estes 4 por desvalidos pagarao' com pena ultima Deus q' olha os pequeninos [réus], e abraça estes q' olham do desprezo; permitio q' a mizericordia se fizesse" ${ }^{708}$.

Assim como os demais contemporâneos do levante, nomeadamente Luís dos Santos Vilhena e o Provedor José Venâncio de Seixas, para frei José de Monte Carmelo o número de culpados era muito maior do que os desembargadores do Tribunal da Relação da Bahia declararam réus. Para esses contemporâneos, ademais, a participação dos cativos não só não foi comprovada, como era uma ameaça a ser evitada a todo custo, de maneira que o episódio "pronta-entrega" de escravos, pela corporação dos enteados, foi paradigmático da participação de homens dos altos setores da sociedade baiana no movimento.

Cumpre destacar que o desfecho da Conjuração Baiana de 1798 ocorreu no mesmo momento em que o governador da capitania da Bahia, d. Fernando José de Portugal e Castro, resolveu definitivamente a missão de São Tomé e Príncipe, que ocorria em paralelo com as investigações da Conjuração Baiana de 1798, quando o exgovernador das ilhas, João Rosendo Tavares Leote e o ex-ouvidor foram condenados por prática de contrabando em sociedade com alguns franceses, que o governador da Bahia, "tacita e negativamente [ficara] em dúvida sobre deverem ser pronunciados [na devassa] os franceses Jacques Baptista e Du-Valle" ${ }^{\text {,709 }}$.

Ocorre que, passados alguns meses, em 31 de outubro de 1799, o então governador de São Tomé e Príncipe, João Baptista da Silva, escreveu ao governador de Angola, D. Miguel Antônio de Mello, Conde de Murça, autor da Informaçan sobre a

\footnotetext{
${ }^{707}$ Luís Henrique Dias Tavares, op.cit., p. 136. Grifo meu.

${ }^{708}$ Ibidem. 137.

${ }^{709}$ BN, Sessão de Manuscritos, C-837, 2.
} 
Bahia, perguntando se ficara em Angola o restante dos armamentos que a Capitania da Bahia deveria enviar às ilhas na Embarcação Vasco da Gama que aportara em Angola, pois dos 400 armamentos, 400 munições e 400 “pretechos de guerra”, o então Capitãomor João Ferreira Guimarães das ilhas só recebera 125 espingardas com baionetas ${ }^{710}$.

A preocupação do governador das Ilhas de São Tomé e Príncipe fazia sentido, pois justamente porque as ilhas eram um importante entreposto no tráfico de escravos com o Golfo da Guiné, essa região passou a ser muito disputada por ingleses e franceses no final do século XVIII. De tal sorte que em 18 de janeiro de 1799, um morador da Ilha do Príncipe escreveu a d. Rodrigo de Sousa Coutinho sobre um levante de escravos que tinha ocorrido no ano interior, com a participação dos governadores interinos Joaquim Pedro Lagranjas e Manoel Monteiro de Carvalho, que em razão de fazerem comércio aberto com a França, os "malditos franceses regressarão por esta Ilha quando vinhão dos seos negócios deixarão está bem infestada do seu contagioso mal q'vai (se alastrando) ${ }^{, 711}$. São várias as denúncias que atestam a prática de comércio aberto com a França nas Ilhas de São Tomé e Príncipe, sem que a coroa portuguesa tomasse alguma medida para proibir tal prática.

Seja como for, a resposta ao governador das Ilhas de São Tomé e Príncipe sobre o envio de armamentos e munições nunca chegaram. No dia 29 de dezembro de 1799 , pouco mais de um mês depois do enforcamento e esquartejamento dos corpos dos réus da Conjuração Baiana de 1798, a França invadiu a Ilha do Príncipe com 500 homens, sem que houvesse qualquer tipo de resistência por parte da tropa da ilha, das autoridades locais, do governador da Bahia, ou mesmo da Coroa Portuguesa ${ }^{712}$, pois, segundo o depoimento do Capitão-mor das Ilhas de São Tomé e Príncipe, em 21 de janeiro de 1800 a Ilha do Príncipe estava "tomada e de posse pelos Francezes, que a tomarão sem resistência por capitulação, 3 Fragatas, das quaes era commandante em chefe João Francisco Landolphe em o dia 29 de dezembro de 1799",713.

Os termos da invasão francesa à Ilha do Príncipe foram esclarecidos na devassa de 1800, a mando de d. Rodrigo de Sousa Coutinho contra o governador das ilhas João Baptista da Silva, realizada pelo governador da Bahia, d. Fernando José de Portugal e

\footnotetext{
${ }^{710}$ BN, Sessão de Manuscritos, 22, 2, 49: Cartas do Brasil ao Governador de Angola D. Miguel Antônio de Mello (1797-1800), p. 20v, 21.

${ }_{711}$ Cf. APEB, Colonial, Maço 210-26, Cx. 80, doc. 4.

${ }^{712}$ AHU_CU_CA_Baía, Caixa 114, doc. 22509. Grifo meu.

713 AHU_CU_CA, Baía, Caixa 114, doc: 22508: Officio do Governador d. Fernando José de Portugal para d. Rodrigo de Sousa Coutinho, sobre a devassa a que mandara proceder para investigação dos factos que era accusado o Governador das Ilhas de S. Thomé e Príncipe João Baptista da Silva. Bahia, 21 de fevereiro de 1801.
} 
Castro, e pelo chanceler da Relação da Bahia, Firmino de Magalhaes Serqueira da Fonseca, que àquela altura era acusado de contrabando de tecidos com a francesa Joana $\mathrm{D}^{\prime}$ Entremeusse ${ }^{714}$. Segundo as testemunhas:

"em lugar de preparar a Artilharia, [o governador] ordenava [que] se tirassem as balas com que estava carregada, respondendo ao Comandante da Fortaleza, quando lhe pedio socorro de gente, que tinha ordem Régia para que a artilharia dos Navios ancorados nos Portos, e das Fortalezas juntas às Povoaçoens, estivessem descarregadas ",715.

Na rápida conclusão da devassa, em 25 de fevereiro de 1801, o governador da Bahia afirmou a d. Rodrigo de Sousa Coutinho, já bastante desgastado na política metropolitana, que de fato as testemunhas da devassa afirmaram que o governador das ilhas sabia do intento da esquadra francesa, "porém resta averiguar se tinha Muniçoens e Pretexos de Guerra, com que se pudesse defender, e he certo que este facto e os mais referidos na Carta, só naquelle lugar se podem melhor examinar" "716. A rapidez com a qual o governador da Bahia conduziu e ajudou a concluir a devassa sobre a denúncia de o governador ter facilitado a invasão francesa na ilha Príncipe não é de pouca relevância. Primeiro porque tudo leva a crer que o governador das ilhas de São Tomé e Príncipe de fato devia saber da invasão francesa, porque sete meses antes, o governador inglês de Cabo Corço avisou o governador das ilhas sobre a existência de três fragatas no Castello de S. Jorge da Mina, cujo destino certamente era as ilhas de São Tomé e Príncipe $^{717}$. Depois, de acordo com o depoimento do Capitão-mor da ilha de São Tomé, João Ferreira Guimarães, a invasão francesa foi facilitada por "Manuel Monteiro de Carvalho e Joaquim Pedro Lagrange, ambos os chefes do levante, que houve n'esta Ilha, [que eram] porém grandes amigos do Governador Geral João Baptista da Silva"718. Além disso, afirmou:

"Estando o S. na Ilha de S. Thomé deu contas a S. M., pelas Secretarias competentes do modo com que governava aquella

\footnotetext{
714 AHU_ACL_CU, 005, Caixa 221, doc. 15413 “Aviso de D. Rodrigo de Sousa Coutinho ao Conde de Resende, remetendo o Offício do Governador da Bahia que acompanha o Treslado da Devassa que se procedeu contra o Chanceler da Relação Firmino de Magalhães Serqueira da Fonseca e contra o Coronel Antônio José Portugal, em virtude do envolvimento com a Francesa Joana D'Entremeusse, acusada de contrabando, para que se dê o expediente necessário”. 20 de abril de 1801.

715 AHU, CU_CA_, São Tomé e Príncipe, Cx. 114, doc. 22515

${ }^{716}$ Idem.

717 AHU_CU_CA, Baía, Caixa 114, doc 22509: Autos da Devassa a que mandou proceder o Ouvidor Geral do Crime por ordem do governador da Bahia, sobre os factos de que era arguido João Baptista da Silva, Governador das Ilhas de S. Thomé e Príncipe, em uma representação do Capitão-mór João Ferreira Guimarães. Bahia, 31 de janeiro, 1801.

${ }^{718}$ Idem.
} 
mesma Ilha o Governador Geral João Baptista da Silva e pelos documentos, com que justificava suas contas, fazia certo a V. M., que o mesmo Governador, desde que chegou à referida Ilha tinha dado evidentes provas de ser o seu objecto arruinar os habitantes d'ella e estabelecer alli huma nova França. Mostrou o mesmo Supplicante por documentos, que justificavão suas contas, que havendo notícia certa de aportar a estas Ilhas huma Esquadra Franceza, que o mesmo Governador nenhuma providência deu para a defeza das mesmas e hindo à Fortaleza de S. Sebastião, a principal defeza da cidade, mandou tirar as ballas com que se achavão as peças carregadas e problicamente despersuadia aos vassallos de V. M., de que combatessem quando fosse occasião, porque elle dava toda a certeza, que, se com os referidos francezes viessem, não havia munições de guerra e armamentos para a defeza da terra [...]",719.

Tudo leva a crer que d. Fernando José de Portugal e Castro e o governador de Angola, d. Miguel Antônio de Mello, o Conde de Murça, tenham retardado o envio das armas com o objetivo de facilitar a invasão francesa à ilha do Príncipe como um dos desdobramentos da política diplomática portuguesa de concessão de territórios, cedendo a ilha do Príncipe à França para preservar a capitania da Bahia, cujo perigo de ameaça foi efetivamente comprovado pelo projeto do Capitão Larcher apresentado ao Diretório Francês em 1798. Além de essa medida significar a possibilidade de Portugal continuar mantendo, naquele final de século, sua tradicional posição de neutralidade diplomática nos conflitos com as Nações Europeias, como aconteceu com as ilhas de Fernando Pó e Ano Bom, cedidas à Espanha, em 1778, o Império Português afastou a possibilidade de a França invadir a capitania da Bahia e ganhou um fôlego em relação às incursões francesas nas Guianas.

A hipótese adquire complexidade se considerarmos que durante o período em que Antônio de Araújo de Azevedo foi Ministro em Paris, 1796-1798, como demonstra Tiago Miranda, o próprio Ministro aliciara o governo francês com a ideia de entregar Timor e Solor para preservar as Guianas, contando na ocasião com o apoio de Luís Pinto de Sousa, Secretário de Estado e Negócios Estrangeiros, e do próprio d. Rodrigo de Sousa Coutinho ${ }^{720}$. Não parece ser por outra razão que $\log$ o depois da invasão francesa à ilha do Príncipe, em janeiro de 1800, o governador da capitania da Bahia, d. Fernando José de Portugal e Castro, e as autoridades metropolitanas receberam um

\footnotetext{
${ }^{719}$ Ibidem.

${ }^{720}$ Cf. Tiago C. P. dos Reis Miranda. Ceder Timor: composição em fuga. REVISTA USP, São Paulo, n.79, p. 82-93, setembro/novembro 2008, p. 84.
} 
documento do Diretório Executivo da República Francesa, intitulado "Liberdade, Igualdade”, sobre a capitulação das ilhas ao Comandante da Divisão Francesa, Joao Francisco Landolphe, sem que tivesse havido nenhuma resistência por parte do governo e das tropas das ilhas ${ }^{721}$.

Cumpre destacar novamente que essa sofisticada negociação diplomática envolvendo os principais funcionários régios da coroa portuguesa ocorreu em um momento em que o governador da capitania da Bahia, d. Fernando José de Portugal e Castro, conseguiu boa parte do empréstimo para animar o crédito público graças à colaboração efetiva dos proprietários que entregaram seus escravos à justiça - junto com os negociantes que conseguiram reverter o processo de prorrogação da arrematação dos dízimos da capitania da Bahia -, e cujas participações foram deixadas às margens das investigações da Conjuração Baiana de 1798.

Após o enforcamento e esquartejamento dos corpos dos réus da Conjuração Baiana de 1798, a corporação dos enteados manteve-se como setor dominante da capitania da Bahia, voltando a ocupar, inclusive cargos na Câmara Municipal de Salvador, afastados desde 1796: Joaquim Inácio de Siqueira Bulcão, cunhado do Secretário de Estado, foi vereador em 1801; o próprio José Pires de Carvalho e Albuquerque foi vereador em 1803; Caetano Maurício Machado e Antônio Joaquim Pires de Carvalho e Albuquerque, filho do Secretário de Estado, foram vereadores em $1804^{722}$. Além disso, como se sabe, d. Fernando José de Portugal e Castro assumiu o vice-reinado em 1801, contando, entre os seus principais colaboradores, o desembargador Francisco Sabino Álvares da Costa Pinto que, como se viu, foi um dos responsáveis pela investigação dos réus da Conjuração Baiana de $1798^{723}$.

Em 22 de dezembro de 1800, Joaquim Pereira Bastos foi nomeado ajudante da Ouvidoria Geral do Cível da capitania da Bahia ${ }^{724}$. Caetano Maurício Machado manteve-se como ajudante de ordens do governo da capitania da Bahia e consolidou-se no tráfico de escravos nas primeiras décadas do século XIX. Francisco Vicente Viana

\footnotetext{
${ }^{721}$ AHU_CU_CA, Cx. 114, doc. 22509.

${ }^{722}$ Cf. Affonso Ruy. História da Câmara Municipal da Cidade do Salvador. Salvador: Câmara Municipal, 1953, pp. 364-367.

723 Cf. Arno Wehling \& Maria José Wehling. Direito e Justiça no Brasil Colonial: o Tribunal da Relação do Rio de Janeiro (1751-1808). Rio de Janeiro: Renovar, 2004.

${ }^{724}$ Arquivo Público do Estado da Bahia, APEB, Livro de Provisões Régias, No. 305 (1797-1801) folhas: 289v. 290. Por quanto Manoel Thomé Jardim de Souza Uzel actual Serventuário de hum dos Ofícios de Escrivão da Ouvidoria Geral do Cível desta Cidade, me representou achar-se impedido o Ajudante q' lhe havia concedido para melhoria do expediente das Partes, pedindo-me ( $q^{\prime}$ nomeasse outro ajudante em razão do impedimento de) Francisco Antonio da Silva. Hey por bem nomear q' sirva de seu Ajudante Joaquim Pereira Bastos em quanto durar o impedimento do dito Ajudante. [...], 22 de setembro de 1800.
} 
também teve consolidada trajetória no comércio dos cativos e, junto com o filho do Secretário de Estado e Governo do Brasil, Antônio Joaquim Pires de Carvalho e Albuquerque, e seu tio, Joaquim Inácio de Siqueira Bulcão, protagonizaram papéis importantes nas lutas pela independência política do Brasil na Bahia - Francisco Vicente Viana foi, inclusive, o primeiro presidente da Província durante o período de $1823-1825^{725}$.

Apesar das duras críticas que d. Rodrigo de Sousa Coutinho fizera ao modo de governar de d. Fernando José de Portugal e Castro, naquele final do século XVIII, a tarefa de fazer em segredo de Estado comentários sobre os regimentos da capitania da Bahia, prospectando um balanço da colonização portuguesa no Brasil e a elaboração de um regimento para o Vice-Reinado, como de fato ocorreu, foi fundamental para a nomeação do governador da capitania da Bahia. A tarefa foi concluída no início de $1801^{726}$, pouco depois da nomeação de d. Fernando José de Portugal e Castro. Cumpre destacar, nesse processo, o relevante papel de José Pires de Carvalho e Albuquerque à frente da Secretaria de Estado. O Secretário de Estado era homem de confiança do governador, seu primeiro oficial de despacho que era consultado em questões pequenas e grandes de Estado, uma vez que ficava aos seus cuidados o arquivo cartorial da jurisdição da Capitania da Bahia, sede do vice-reinado até $1763^{727}$.

Tempos depois, em 1808, quando as naus que transportaram a família real ao Brasil aportaram no porto da Bahia, um dos poucos lugares em que o Príncipe Regente e sua família estiveram foi na casa de um dos proprietários dos escravos entregues a justiça durante a investigação dos réus da Conjuração Baiana de 1798, o negociante e tesoureiro Manoel José Vilella de Carvalho, que durante o Império foi condecorado Fidalgo Cavalheiro da Imperial Casa de Vossa Majestade Imperial ${ }^{728}$. Além disso, no mesmo ano de 1808, depois do falecimento do Secretário de Estado e Governo do Brasil, José Pires de Carvalho e Albuquerque, por ocasião do seu inventário, a viúva d.

\footnotetext{
725 Braz H. do Amaral. Historia da independência na Bahia. Salvador: Liv. Progresso, 1957; Luís Henrique Dias Tavares. A Independência do Brasil na Bahia. Rio de Janeiro: Civilização Brasileira/Brasília: INL, 1982.

${ }^{726}$ BN, Divisão de Manuscritos, Fundo Marquês de Aguiar, doc. 9, 2, 26 de 10 de maio de 1804. "Regimento dos Governadores Gerais do Brasil com as observações do Ilmo. Sr. Vice-Rei Dom Fernando José de Portugal e Castro”. A transcrição parcialmente integral desse documento está em Marcos Carneiro de Mendonça. Raízes da formação administrativa do Brasil. Rio de Janeiro: IHGB/Conselho Federal de Cultura, 1972, Vols. I e II.

727 A respeito da relevância da Secretária de Estado do Brasil, ler: Pedro Puntoni. Bernardo Vieira Ravasco, secretário do Estado do Brasil: poder e elites na Bahia do século XVII. In: Modos de Governar: ideias e práticas políticas no Império Português, séculos XVI-XIX. São Paulo: Alameda, 2005, p. 164.

${ }^{728}$ BN, Sessão de Manuscritos, C-528-3/0705,- 009, nº 1 e C-701-9.
} 
Anna Maria de São José e Aragão solicitou o teor da Carta Régia de propriedade do ofício de Secretário de Estado que S. A. R. tinha concedido ao seu filho primogênito, Antônio Joaquim Pires de Carvalho e Albuquerque, que afirmava o seguinte:

"hey por bem fazer-lhe mercê da Propriedade do dito Officio da mesma forma que foi concedido ao referido seo Pay, com a denominação de Secretário de Estado e Governo da Bahia, por não convir mais nas atuais circunstâncias a antiga denominação [...] $]^{, 729}$.

${ }^{729}$ APEB, Judiciário, Inventário de José Pires de Carvalho e Albuquerque, 1808/01/97/141/02, folhas $121,121 \mathrm{v}$. Grifo meu. 


\section{Conclusões}

As conclusões que resultam da análise da Conjuração Baiana de 1798, especialmente as razões e o modo pelo qual a corporação dos enteados participou do movimento político, obviamente ultrapassam os limites do acontecimento. No primeiro capítulo, tempos de tensão, demonstrou-se que a transferência da sede do Vice-Reinado para a capitania do Rio de Janeiro não impediu que a capitania da Bahia, sob o governo de d. Fernando José de Portugal e Castro (1788-1801), consolidasse-se em um importante centro de decisão política naquele tumultuado final de século, cujos desdobramentos interferiram nos rumos políticos do Império Português. A conformação da capitalidade da capitania da Bahia, compartilhada com o Vice-Reinado do Rio de Janeiro, decorreu de sua expansão econômica e da atuação do governador d. Fernando José de Portugal e Castro em conjunto com os membros da corporação dos enteados, sobretudo do Secretário de Estado e Governo do Brasil, José Pires de Carvalho e Albuquerque.

Nascido na Bahia, proprietário do morgado da Casa da Torre por casamento com Ana Maria de São José e Aragão, e dos engenhos de Cazumbá, Rosário, Passagem, São Miguel e Nossa Senhora da Conceição, José Pires e Carvalho e Albuquerque "serviu nos empregos" Intendente da Marinha e Armazéns Reais, Vedor Geral do Exército, Provedor e Ouvidor da Alfândega da Bahia e Deputado da Junta da Real Fazenda. Homem poderoso na Bahia do final do século XVIII, o Secretário de Estado e Governo do Brasil pagou duas vezes pela vitaliciedade de seu ofício, conseguindo, inclusive a mudança de nome de seu cargo, o que demonstra a centralidade do ofício no governo da capitania da Bahia e, em certo sentido, no Império Português. Sua crescente influência política e econômica na Bahia do final do século XVIII relaciona-se ao fato dele ter sido um importante credor da Real Fazenda, que contava com o apoio de alguns Desembargadores do Tribunal da Relação da Bahia, de um tio na Casa da Suplicação e do próprio governador da Bahia, d. Fernando José de Portugal e Castro.

No segundo capítulo, tempos de contestação, demonstrou-se, portanto, os principais pontos das reformas de d. Rodrigo de Sousa Coutinho que contrariavam os interesses da corporação dos enteados, especialmente os interesses do Secretário de Estado e Governo do Brasil que viu a vitaliciedade de seu cargo e seus privilégios efetivamente ameaçados, assim como d. Fernando José de Portugal e Castro que se 
sentiu ameaçado quando d. Rodrigo de Sousa Coutinho criticou-o duramente e, em 1797, sugeriu seu irmão, Francisco de Sousa Coutinho, para ocupar o Vice-Rei. A partir de 1796, não à toa, as atitudes de d. Fernando José de Portugal e Castro demonstram que sob a aparente afabilidade, contemporização e frouxidão de caráter, constantemente retratada por seus contemporâneos, havia um projeto político que se desenhava naqueles anos finais do século XVIII, no qual o governador da capitania da Bahia agia em comunhão com alguns Ministros do Tribunal da Relação da Bahia e um grupo de notáveis que, apesar de protagonizarem muitas contendas e serem constantemente denunciados por prática de contrabando, enriquecimento ilícito e desordens administrativas, foram muito importantes para a manutenção do poder da coroa portuguesa na época.

Muito da postura de d. Fernando José de Portugal e Castro e da própria coroa portuguesa se deve ao fato de que os homens que compunham a corporação dos enteados estavam direta ou indiretamente ligados ao controle da produção econômica para exportação na capitania da Bahia naquele final de século, seja como senhores de engenho, seja como credores e tomadores de crédito, seja como sócios no tráfico de escravos, seja como sócios na arrematação do contrato dos dízimos reais. Situação que dependia da manutenção das regras do jogo político entre a coroa portuguesa e o setor privilegiado da principal capitania da colônia, que passou a ser ameaçada após d. Rodrigo de Sousa Coutinho assumir a Secretaria de Estado dos Negócios da Marinha e Domínios Ultramarinos, em 1796, e a elaboração de uma série de reformas para a dinamização do Império Português que, contraditoriamente, forçou uma tomada de consciência da exploração colonial. Não parece ser por outra razão que as reivindicações da corporação dos enteados nos últimos anos do século XVIII dizem respeito à internalização de seus interesses e a consolidação de suas posições políticas no sistema, não se tratando, portanto, da harmonização dos interesses dos dois polos do sistema, de que resultaria a prosperidade comum.

Nesse sentido, o fortalecimento político do governador da capitania da Bahia, d. Fernando José de Portugal e Castro, com sua nomeação para o Vice-Reinado do Brasil, em 1800, é paradigmático das decisões da coroa portuguesa, cujos mecanismos para tentar superar as contradições irreversíveis da realidade da colonial acabaram por obstaculizar a modernização do Império Português, à medida que naquela conflituosa conjuntura de final de século parece não ter havido alternativa que não fosse privilegiar as demandas da corporação dos enteados em detrimento dos interesses dos 
negociantes portugueses, como ocorreu com a reversão do decreto que prorrogava sucessivamente a arrematação do contrato do dízimo para o grupo de negociantes portugueses, comandados por Antônio José Ferreira. Essa situação ocorreu apenas na capitania da Bahia, pois nas capitanias de São Paulo e Pernambuco os negociantes portugueses continuaram controlando o contrato do dízimo.

Não parece ser por acaso que a contenda sobre a arrematação do dízimo na capitania da Bahia só foi definitivamente resolvida em benefício dos negociantes soteropolitanos após a deflagração do movimento político, com a publicação dos boletins manuscritos na manhã de 12 de agosto de 1798. A análise sobre as categorias sociais arroladas nos boletins manuscritos demonstra que o Partido da Liberdade era composto pelos altos e médios setores da sociedade soteropolitana da época. Nesse sentido, o episódio "pronta entrega de escravos", no qual os proprietários que compunham a corporação dos enteados entregaram alguns de seus escravos à justiça para livrarem-se da acusação de prática sediciosa, comprova a ausência de cativos entre as categorias sociais arroladas nos boletins. Além disso, esse episódio e a pergunta que os milicianos fizeram aos escravos: "estima a liberdade e ser forro?", revelam um ponto de intersecção das estratégias do fazer política dos partícipes que objetivava conferir maior densidade ao movimento, à medida que o verdadeiro perigo a ser evitado era justamente a participação dos escravos em um movimento de natureza contestatória, que abalaria, em definitivo, os alicerces da colonização.

Estratégia política comum que revela também as tensões e contradições do conceito de liberdade em uma sociedade colonial. Apesar de a documentação analisada não nos autorizar a afirmar que a liberdade dos escravos era uma agenda política dos partícipes do movimento, ela demonstra a radicalidade do discurso e da ação política dos altos e médios setores que se valeram da ameaça e da possibilidade de liberdade dos cativos para explicitarem suas demandas nas ruas de Salvador - colocando em risco a legitimidade da desigualdade entre os homens e, portanto, os seus próprios privilégios. Ao elaborarem um conceito de liberdade ambíguo que, no final das contas, fundamentou a revisão dos termos do pacto colonial expressa nos boletins manuscritos, especialmente o Aviso $\mathrm{n}^{\circ}$ 9, a reforma desejada pelos altos setores que participaram do movimento seria aquela que preservasse a coroa portuguesa como ordenadora natural das desigualdades constituídas, mantendo práticas mercantilistas que lhes fossem favoráveis para a internalização de seus interesses políticos e econômicos com a miragem do livre comércio. 
É inegável que a virtual participação dos cativos no movimento e a ameaça que isso significaria naquela sociedade foram superdimensionadas na afirmação de que “todos os homens pardos e pretos seriam iguais na República Bahinense", mas a politização do discurso também ocorreu quando os boletins manuscritos anunciaram alinhamento político com Castela e a "ajuda estrangeira" da França revolucionária que naqueles anos finais do século XVIII, tinha de fato interesse em invadir a região das guianas e a capitania da Bahia, conforme o projeto do Capitão Larcher apresentado ao Diretório no início de 1798. Até o momento, no entanto, não há comprovação documental de que esse projeto tenha sido elaborado em conjunto com os homens da corporação dos enteados, apesar do forte indício de que Larcher tenha se socializado durante o curto período em que esteve em Salvador com pessoas dos altos setores. Essa situação, entretanto, permite-nos conjecturar que o plano do Capitão francês tenha servido para radicalizar o discurso dos boletins manuscritos, à medida que no horizonte de expectativas da coroa portuguesa esse era um dos grandes perigos a ser evitado.

Parece inegável que tanto a radicalidade do discurso quanto as práticas políticas dos médios e altos setores que participaram do movimento conferem especificidade à Conjuração Baiana de 1798, sobretudo porque se constituíram em uma cultura política que passava ao largo dos definidos e intransponíveis recortes sociais que legitimavam e legalizavam as bases de uma sociedade colonial escravista de Antigo Regime. Apesar da radicalidade do discurso ao entrever a liberdade dos cativos e a ameaça de ajuda francesa, os episódios "pronta entrega de escravos" e a concessão da ilha do Príncipe à França, em 1799, não nos autoriza afirmar a existência de um ensaio consciente para instaurar uma nova ordem, mas de ações que buscavam o reordenamento das condições operativas da coisa pública, afastando em definitivo o recrudescimento da exploração colonial e a possibilidade de internalização dos interesses dos altos setores que seriam comprometidos com a implantação de alguns pontos controversos das reformas de d. Rodrigo de Sousa Coutinho.

No entanto, a participação de homens dos altos e médios setores no movimento é reveladora da síntese contraditória das práticas e das demandas políticas e econômicas dos envolvidos, à medida que os altos setores objetivavam a permanência das políticas mercantilistas e absolutistas que reafirmavam e ampliariam suas privilegiadas posições naquela sociedade; e os setores médios objetivavam a mudança nos critérios de ascensão aos postos militares e abririam brechas para suas participações políticas. A percepção da crise consolida-se, portanto, na constatação de demandas políticas e 
conflitantes dos partícipes do movimento, que impôs à coroa portuguesa soluções de compromisso com a corporação dos enteados para obter a adesão desses notáveis ao projeto reformista em curso que após a deflagração da Conjuração Baiana de 1798, passou a ser operacionalizado na colônia por d. Fernando José de Portugal e Castro, porque soube preservar os interesses das elites coloniais e, portanto, construir um consenso político que permitiu à coroa portuguesa continuar governando a conflitualidade no interior dos setores dominantes e reforçar o domínio colonial, como se demonstrou no terceiro capítulo, tempos de negociação.

Se a especificidade da Conjuração Baiana de 1798 reside na radicalidade do discurso e do fazer política pelos altos e médios setores da sociedade soteropolitana da época, a sua reiteração em relação aos outros movimentos de natureza contestatória, sobretudo a Inconfidência Mineira de 1789, reside na consciência da exploração e da consequente necessidade de reordenamentos para a manutenção das linhas gerais do sistema para a consolidação de seus interesses. Embora seja o único movimento de natureza contestatória, no Brasil do final do século XVIII, que contou com o envolvimento de homens dos altos e médios setores da sociedade, a síntese contraditória de suas demandas não nos autoriza a analisá-lo como portador de uma das possibilidades de aliança ou cooperação de classes em torno de objetivos comuns, anunciando a dissolução da sociedade de tipo Antigo Regime na Bahia. Ao contrário.

A condução das devassas da Conjuração Baiana de 1798, cujos desembargadores, governador da capitania da Bahia e Secretário de Estado e Governo do Brasil circunscreveram de antemão o protagonismo político dos milicianos, é paradigmática da luta entre os médios e altos setores envolvidos no movimento. A análise das devassas abertas para se descobrir o autor dos boletins manuscritos e os partícipes do evento revela que, no lugar de "cooperação de classes", o que ocorreu foi que homens da corporação dos enteados recuaram politicamente e passaram a colaborar efetivamente com as investigações, entregando seus escravos à justiça e formulando denúncias sobre a exclusiva participação dos setores médios no movimento. Durante os depoimentos das testemunhas e dos homens presos no Segredo da Relação, fica claro o tom pedagógico sobre a necessidade de preservação do status quo como o principal meio de se evitar uma conflagração social advinda do fazer político por homens de distintos setores sociais e do necessário alinhamento político entre a coroa e o setor dominante da capitania da Bahia, que lhe garantia base social para a manutenção do poder político. 
O que as autoridades régias perceberam é que não bastava deixar os homens dos altos setores à margem das investigações para o restabelecimento da ordem. Embora o projeto político dos altos setores envolvidos no movimento fosse pela conservação do sistema com o objetivo de manter e ampliar seus privilégios políticos e econômicos, era preciso eliminar no interior das elites coloniais, especialmente entre os membros da corporação dos enteados, o rastro da experiência política quando homens de distintos setores sociais elaboraram e explicitaram suas demandas nas ruas de Salvador. Não bastava convencer os altos setores sobre o risco de deflagração social subjacente à prática política do movimento. Foi preciso empreender uma série de soluções de compromisso com a corporação dos enteados para criar um consenso político em torno do qual esses homens continuariam a constituir, na colônia, a base social para a manutenção do poder da coroa portuguesa. Entre as várias soluções de compromisso demonstradas nesta tese, a principal delas foi a seletiva e violenta repressão das autoridades locais sobre os milicianos, que afastou o ideário político e econômico esboçado nos boletins manuscritos e condenou à morte os homens dos médios setores que cavaram brechas para suas participações no universo da política restrito aos homens virtuosos, na tradição de Montesquieu.

Por isso, o enforcamento e o esquartejamento dos corpos de Luiz Gonzaga das Virgens e Veiga, Lucas Dantas de Amorim Torres, Manuel Faustino e João de Deus do Nascimento, na manhã de 8 de novembro de 1799, na praça da Piedade em Salvador, é paradigmático dos desdobramentos da Conjuração Baiana de 1798, cujo projeto político conservador dos altos setores do movimento saiu vitorioso. Trata-se, portanto, de um movimento político de inegável natureza contestatória, ocorrido em duas fases durante o período de 1796-1800, que contou com a participação dos altos e médios setores da sociedade soteropolitana da época, cuja principal consequência foi eliminar a incômoda e desprestigiada condição de "enteados" na estrutura do Império Português para restabelecer-lhes a condição de súditos da coroa portuguesa. 


\section{Documentação}

\section{A.- Biblioteca Nacional}

- Fundo Marquês de Aguiar, Ofícios 1796-1799;

- 5, 2, 15 - Provisões de Officiaes de Justiça passadas;

- 5, 2, 16 - Chartas de Offício, Bahia, 796-1798;

- $5,2,17, \mathrm{n}^{\mathrm{o}} 110$ - Memória e Rezumo de todas as Ordens Reaes;

- 6, 2, 5- Portarias expedidas por d. Fernando José de Portugal e Castro;

- 3, 3, 7-8 - Chartas, Portarias e Ordens Régias, Bahia, (1797-1799);

- 1, 4, 7 - Provisões Régias expedidas pelo Conselho Ultramarino e outros Tribunaes;

- 1, 4, 8-9 - Ordens Régias para o Governador e Capitão General da Bahia (17961799);

- 1, 4, 10-13 - Chartas de d. Fernando José de Portugal e Castro;

- 1, 4, 16 - Chartas que escreveu o Ilmo. Exmo. d. Fernando José de Portugal e Castro;

- $1,4,17$, vol. 1 - Provisões Reaes;

- 2, 4, 1-2, vols. 2 e 3 - Portarias do Expediente do Governo da Bahia (1795$1800)$;

- 06,3,009: Coleção cronológica e analítica em que se compreendem todas as providências administrativas, políticas e econômicas que se expediram ao vicerei do Estado do Brasil por ordem do príncipe regente, 1796-1800;

- II-30,31,049: Carta de apresentação de Baltazar de Silva lisboa, ouvidor dos Ilheus, por D. Rodrigo de Souza Coutinho, 19/06/1797;

- II-31,02,020 n009: Ordens régias para que se impeça, de todas as maneiras, a violação do tratado de limites com os espanhóis, no sul do Brasil e circular premiando os defensores das costas brasileiras contra os franceses, 1797;

- 22,2,49: Cartas do Brasil ao Governante de Angola D. Miguel Antonio de Melo, 1797-1800;

- I-29,13,27 n²-70: Minuta de ordens expedidas, dirigidas ao reino de Angola e a todos os seus domínios, 1797-1801;

- I-29,16,29: Correspondência e outros documentos relativos à sessões da conferência acerca das negociações de paz entre Espanha, Portugal e Inglaterra com o governo francês. Madri e Lisboa, 13/09/1797 e 20/10/1801.

- I-28,25,030: Relatório ao Conde de Linhares, sobre as relações políticas entre Portugal e Brasil, por Francisco Souza Coutinho, Pará, 20/09/1797;

- II-30,35,010: Discurso de D. Rodrigo de Souza Coutinho na Abertura da Sociedade Real Marítima, 1798;

- 10, 2, 005: Antonio de Araújo Azevedo, Correspondências referentes à paz entre Portugal e França, 1796-1798; 
- I-33,35,024: Correspondência entre o Governador e capitao geral da Bahia, Miguel Antônio de Mello e Fernando José Portugal, referindo-se a cartas anteriores, acompanhando relaçao de três degredados, requerendo que os mestres das embarcaçoes apresentem certidao a fim de se evitarem fraudes no porto, 10/04/1798;

- C-0259,013: Requerimento encaminhado ao Ministério do Império, solicitando entrega da parte que cabe a sua mulher Joaquina Mauricia de Sao Miguel e Aragao, na herança de Jose Pires de Carvalho e Albuquerque, 1813. Joaquim Ignácio de Siqueira Bulcão, $1^{\circ}$ Barão de São Francisco.

\section{B.- Arquivo Público do Estado da Bahia}

- Livro de Notas: 117, f. 430; 144, f. 506; 146, f. 272; 160, f. 97v; 150, f. 66v;

- Livro de Notas: empréstimos, livros 100-102;

- Cartas Régias de 1798, Livros 184 e 185;

- Códice 632: Matrícula dos engenhos da Capitania da Bahia, 1807;

- Códice 139: Registro de Correspondências expedidas para o Rei (17991800);

- Códice 263-2: Livro de Provisões Reais;

- Códice 471: Portarias e Registros;

- Maços: 138, 158, 158-1, 177, Ouvidoria Geral do Crime, período de 17951800 ;

- Códice 197: Governo das Ilhas de São Tomé e Príncipe, período colonial;

- Maço 201, documentos 21-28: Correspondências das autoridades das Ilhas de São Tomé e Príncipe com o Governador da Bahia (1795-1800);

- Judiciário, Inventários post-mortem: José Pires de Carvalho e Albuquerque (1/97/141/2); Francisco Vicente Viana (03/1040/1509/10); Bernardino de Sena e Araújo; Caetano Maurício Machado (03/1145/1614/06); Manoel José Vilella de Carvalho (08/3396/15);

- Cartas ao Governo, Senado da Câmara, 1783-1799, Maços 201-214;

- Judiciário, Escrituras, Livros 139 e 140.

\section{C.- Arquivo Histórico da Santa Casa de Misericórdia da Bahia.}

- $\quad$ Livro $n^{\circ} 5$ da Mesa e Junta (1791-1834), nº 16;

- $\quad$ Livro $\mathrm{n}^{\mathrm{o}} 4$ copiador (1758-1804), $\mathrm{n}^{\mathrm{o}} 54$;

- Livro de Demandas da Santa Casa (1783-1813), n 161;

- Livro de Ordem dos Governadores dirigidos à Santa Casa (1722-1820), nº 162; 
- $\quad$ Livro $2^{\circ}$ de Registro (1776-1817), $\mathrm{n}^{\circ}$ 86;

- Livro dos Segredos desta Santa Casa (1679-1809), nº 195;

- $\quad$ Livro $3^{\circ}$ de Tombo (1686-1849), nº 42;

- Maços Avulsos de Receitas e Despesas (1795-1799).

\section{D.- Arquivo Municipal da Cidade de Salvador}

- Arrematação das rendas da Câmara: 1775-1808, 1781-1798, 1798-1809;

- Fianças: 1789-1795, 1793-1808, 1795-1802;

- Licenças: 1792-1796, 1797-1801;

- Livro de Registro da Renda e Despesa do Matadouro: 1768-1807;

- Ofícios ao Governo: 1768-1807;

- Portarias: 1795-1798, 1798-1800;

- Provisões Reais: 1788-1798;

- Posturas: 1792-1799.

\section{E.- Arquivo Nacional da Torre do Tombo}

- Ministério do Reino, Chancelaria de d. Maria I: livros 55-85, Registro Geral de Mercês e Decretos;

- Ministério do Reino, Chancelaria de d. João VI: livros 1-20, Registro Geral de Mercês e Decretos;

- Casa da Suplicação: códices Juízo da Inconfidência e dos Ausentes e Juízo da Provedoria dos Resíduos e dos Cativos, período (1790-1801);

- Índice Cronológico de Leis, Livro 8;

- O Desembargo do Paço: códices Leitura de Bacharéis e Habilitação de Magistrados do Tribunal da Relação da Bahia, período (1790-1801);

- Mesa da Consciência e Ordens: Livros de Provisões e Registros Gerais, Bahia 1790-1801, Códices Padroados do Brasil, Bahia, Maços 1-3, Consultas do Conselho Ultramarino, Bahia (1790-1801) - maços 312-324;

- Negócios relativos ao Ultramar e Ilhas, Maços 500 e 599, Bahia e São Tomé e Príncipe (1790-1801);

- Real Mesa Censória: IDDs, L 513-516, L 572;

- Secretaria de Estado e Ministério dos Negócios Estrangeiros: Bahia, livros 830840, período (1790-1801);

- Arquivo central das Secretarias de Estado, IDD L 382;

- Conselho da Fazenda, L 119: Registro de Cartas, Alvarás e Provisões nº 379397 e Registros da Fazenda, Bahia (1790-1801);

- Erário Régio, Bahia, L 524 (1790-1801), Livro de Registro da Casa da Moeda, L 512, (1790-1797); 
- Real Junta do Comércio, Agricultura, Fábricas e Navegação: códice "Copiador de Correspondência com o Brasil", maço 329, Caixa 37; Junta do Comércio: Maços 11 e 12;

- Inventários Orfanológicos de 70 comerciantes (1790-1801);

- Feitos Findos, Brasil, Cx. 283;

- Registro Geral de Testamentos;

- Habilitações de Cristo: José Pires de Carvalho e Albuquerque, filho de outro do mesmo nome, e de D. Isabel Joaquina de Aragão. De 19 de maio de 1779. Habilitação da Ordem de Cristo. Letra J, Maço 49, número 5; Bernardino de Sena e Araújo. Habilitação da Ordem de Cristo, Letra B, Maço 9, número 1; Caetano Maurício Machado. Habilitação da Ordem de Cristo, Letra C, Maço 8, número 3; Manoel José Vilela de Carvalho. Habilitação da Ordem de Cristo, Letra M, Maço 37, número 8; Manoel José Vilela de Carvalho. Habilitação da Ordem de Cristo, Letra M, Maço 29, número 42.

\section{F.- Arquivo Histórico Ultramarino.}

- Manuscritos das Ilhas de São Tomé e Príncipe: Caixas 29, 30, 31.

- Projeto Resgate/Reencontro, Bahia, Avulsos, Castro e Almeida e Luísa da Fonseca durante o período de 1788-1801.

\section{G.- Fontes do Arquivo Nacional}

- Registro de provisões e alvarás régios e do governador general do Brasil e do vice-rei; portarias e ordens do governo-geral do Brasil; mandados do vice-rei; nomeações; termos e petições: códice 141, vols. 16 (17791798) e 17 (1794-1804), Alfândega da Bahia;

- Coleção Negócios de Portugal. Caixa 715, pacote 02, 1797. Carta de d. Rodrigo de Sousa Coutinho ao príncipe regente d. João aconselhando a nomeação de governadores para as capitanias

- Capitanias da Bahia, Alagoas, Ceará, Goiás, Maranhão, Mato Grosso, Paraíba, Pernambuco, Piauí, São Paulo, Santa Catarina, Caixa 748 (1770-1813), Vice-Reinado, D9;

- Correspondência com Portugal - minutas e ofícios, Caixa 494, pct. 01 (1762-1803), Vice-reinado, D9;

- Correspondência de diversas autoridades com os vice-reis, Caixa 485, pct. 03 (1760-1808), Vice-reinado, D9;

- Correspondência do Vice-rei. Regimento para os Governadores do Brasil, Caixa 744, pct. 01 (1763-1807), Vice-reinado, D9;

- Correspondência do Vice-rei. Regimento para os governadores do Brasil, Caixa 744, pct. 03, (1773-1818), Vice-rei, D9;

- Correspondência do governador de Angola com Vice-reis, Caixa 502 (1790-1807), Vice-reinado, D9; 
- Sinopse das sesmarias registradas no arquivo da Tesouraria da Fazenda da Bahia, Códice 155, (1534-1828), Tesouraria da Fazenda da província da Bahia, BX;

- Auto de posse dos Vice-reis, Códice 774, (1763-1806), Secretaria de Estado do Brasil, 86;

- Cartas régias, provisões, alvarás e avisos, Códice 952, vol. 45, (17961796), Secretaria de Estado do Brasil, 86;

- Correspondência da Bahia sobre cobrança dos dízimos reais, compra de escravos e sobre outros assuntos, Códice 91, (1789-1807), Secretaria de Estado do Brasil, 86;

- Correspondência da Corte com o Vice-reinado, Códice 67, vol. 19, (1790-1800), Secretaria de Estado do Brasil, 86;

- Registro da Correspondência do Vice-reinado com diversas autoridades, Códice 70, vol. 17, (1793-1801), Secretaria de Estado do Brasil, 86;

- Registro geral de ordens, Códice 64, vol. 23, (1785-1798), Secretaria de Estado do Brasil, 86;

- Correspondência original do vice-reinado com o comissário em Buenos Aires, Vicente José Velasco Molina, para a execução do Tratado de Paz e Limites com a Espanha, Códice 92, vol. 05, (1791-1808), Secretaria de Estado do Brasil, 86;

- Registro e índice de ordens régias 241 existentes no arquivo da Junta da Fazenda da Bahia sobre assuntos eclesiásticos, compra de madeira, hospitais e casas de misericórdia, Casa da Moeda, oficiais e soldados, nomeações de médicos, naus e navios, obras pias, Códice 539, vol. 04, (1606-1800), Relação da Bahia, 83;

- Catálogo cronológico de avisos, provisões, cartas régias e alvarás que existem na Secretaria de Estado do Reino de Angola, Códice 543, (16001882), Negócios de Portugal, 59.

\section{H.- Fontes do Arquivo do Instituto Histórico e Geográfico do Brasil}

- Fundação da Casa da Moeda da Bahia, RIHGB, 33(40): 123-134, 1870;

- Ricardo Teles Araújo (Coord). Habilitandos brasileiros às ordens militares, ao Santo Ofício e à leitura de bacharéis, RIHGB, 158 (394): 281-350, jan/mar, 1997;

- Diogo de Vasconcelos. Linhas gerais da administração colonial: como se exercia o vice-rei, os capitães-mores de capitanias e os capitães-mores de ilhas e cidades. RIHGB, v. 3, 1914. P. 281-298;

- Maria Isabel de Albuquerque. Convento do Desterro da Bahia, RIHBG, V., 8, pp. 415-430, 1949;

- Ubiratan de Castro Araújo. A colônia da Bahia, RIHGB, Ano 161, n 408, pp. 203-223, jul/set, 2000; 
- Luciano Figueiredo. Memória sobre bens regulares, caixas de crédito e circulação: tributos, direitos, manufatura de pólvora e ferro. RIHGB, A. 163, no 416, pp. 89-92, jul/set., 2002;

- Paulo Cavalcante de Oliveira Júnior. O caminho do descaminho: relações de poder e ilicitude na colônia. RIHGB, Ano 167, no 432, pp. 159-171, jul/set, 2006;

- Mapa demonstrativo da receita e despesa da capitania da Bahia pelos diferentes cofres nos dez anos de 1791 a 1800: doação do manuscrito. T.2, p. 405, 1840; $2^{\text {a }}$ ed., p. 407; $3^{\text {a }}$ ed., p. 419;

- Fragmentos de uma memória sobre as sesmarias da Bahia do Marquês de Aguiar: doação de manuscrito. T. 3, 1841; $2^{\mathrm{a}}$ ed., p. 373; $3^{\mathrm{a}}$ ed., p. 302;

- Memória topográfica, histórica, comercial e política da Vila de Cachoeira, da Província da Bahia, de José Joaquim de Almeida Arnizau: doação do manuscrito. RIHGB, 24: 759, 1861;

- Papel sobre a discórdia que houve entre o almotacel-mor Antônio da Câmara Coutinho, o governador da Bahia e o arcebispo d. João Francisco de Oliveira, RIHGB, 12:288, 1849; DL 1527.074;

- Carta, comunicando regresso à Bahia e solicitando papéis relativos à execução hipotecária movido pelo banco emissor da Bahia contra o Barão e a Baronesa de Pirajá e as notas do processo de inventário dos mesmos. Arquivo Wanderley Pinho, DL 1568.019;

- Bahia e baianos: Visconde de Pirajá (a propósito do episódio da Sabinada). Arquivo Wanderley Pinho, Arq. 1. 1. 019.

- Ofício, expondo as quantias que de sua casa e de seu pai se tem oferecido a Real Fazenda no espaço de 30 anos (José Pires de Carvalho e Albuquerque). CU, vol. 19, p. 221v; IHGB, Arq. 1.1.019;

- Correspondência sobre negócios da Bahia (José Pires de Carvalho e Albuquerque). CU, v. 200; IHGB, DL

- Cartão de visitas, pedindo indicação da data de falecimento do Barão do Rio das Contas, Francisco Vicente Viana. DL 1538.067;

- Cartões de visitas de Fructuoso Vicente Viana; Antônio de Argolo; Viscondessa de São Lourenço; Viscondessa de Passé. DL 1603.019;

- Notas genealógicas sobre: Francisco Vicente Viana ( ${ }^{\circ}$ Barão do Rio das Contas). DL 1603.019;

- Memórias da Província Carmelitana da Bahia, 1798. Notas. DL 1601.12

\section{I.- Arquivo Histórico Theodoro Sampaio, Arquivo do Instituto Geográfico e Histórico da Bahia.}

- Arquivo Pessoal de Francisco Vicente Viana, Caixas 01 e 02;

- Arquivo Pessoal de Antônio de Araújo de Aragão Bulcão Sobrinho. 
J.- Arquivo Histórico do Itamaraty.

\begin{tabular}{|c|c|c|c|c|}
\hline Descrição & Data & Lata & Maço & Pasta \\
\hline $\begin{array}{l}\text { Casos com embarcações - Capitão } \\
\text { Larcher } 1797 .\end{array}$ & 1799 & 169 & 4 & 1 \\
\hline $\begin{array}{l}\text { Carta do Conde de Resende para d. } \\
\text { Rodrigo de Sousa Coutinho, com } \\
\text { despachos de d. João VI. }\end{array}$ & 1800 & 169 & 4 & 1 \\
\hline $\begin{array}{l}\text { Manifesto do Príncipe Regente de } \\
1 / 5 / 1808 \text {, sobre: esboço enviado } \\
\text { em carta de d. Rodrigo de Sousa } \\
\text { Coutinho ao Visconde de Anadia }\end{array}$ & 1808 & 170 & 3 & 3 \\
\hline $\begin{array}{l}\text { D. Fernando José de Portugal e } \\
\text { Castro: correspondência recebida }\end{array}$ & 1811 & 171 & 1 & 8 \\
\hline $\begin{array}{l}\text { D. Fernando José de Portugal e } \\
\text { Castro: correspondência recebida }\end{array}$ & $1792-1812$ & 171 & 1 & 5 \\
\hline $\begin{array}{l}\text { D. Francisco de Sousa Coutinho: } \\
\text { correspondência expedida }\end{array}$ & 1791-1794 & 172 & 2 & 11 \\
\hline $\begin{array}{l}\text { D. Francisco de Sousa Coutinho: } \\
\text { correspondência expedida }\end{array}$ & 1797 & 172 & 2 & 12 \\
\hline $\begin{array}{l}\text { D. Rodrigo de Sousa Coutinho: } \\
\text { correspondência recebida }\end{array}$ & 1798 & 175 & 5 & 6 \\
\hline $\begin{array}{l}\text { D. Rodrigo de Sousa Coutinho: } \\
\text { correspondência recebida }\end{array}$ & 1808 & 175 & 5 & 9 \\
\hline $\begin{array}{l}\text { D. Rodrigo de Sousa Coutinho: } \\
\text { correspondência expedida }\end{array}$ & 1809 & 176 & 1 & 11 \\
\hline $\begin{array}{l}\text { D. Rodrigo de Sousa Coutinho: } \\
\text { correspondência expedida }\end{array}$ & 1808-1811 & 176 & 2 & 10 \\
\hline $\begin{array}{l}\text { Vicente José de Velasco Molina } \\
\text { com d. Fernando José de Portugal }\end{array}$ & 1779-1807 & 178 & 3 & 3 \\
\hline $\begin{array}{l}\text { Vicente José de Velasco Molina } \\
\text { com d. Fernando José de Portugal }\end{array}$ & 1800-1804 & 178 & 5 & 1 \\
\hline $\begin{array}{l}\text { Tomás Antônio de Vilanova } \\
\text { Portugal da marquesa de Aguiar }\end{array}$ & 1818 & 179 & 3 & 1 \\
\hline
\end{tabular}




\begin{tabular}{|c|c|c|c|c|}
\hline $\begin{array}{l}\text { D. José de Castro (Conde de } \\
\text { Resende) com d. Rodrigo de Sousa } \\
\text { Coutinho }\end{array}$ & 1795-1799 & 181 & 4 & 7 \\
\hline $\begin{array}{l}\text { Carta dirigida ao reverendo Bispo } \\
\text { de Pernambuco e aos governadores } \\
\text { interinos da Capitania de } \\
\text { Pernambuco, pelo Príncipe de } \\
\text { Portugal, acerca do contrato dos } \\
\text { dízimos na Bahia. }\end{array}$ & 1801 & 184 & 1 & 8 \\
\hline $\begin{array}{l}\text { Lei relativa aos embaixadores, } \\
\text { ministros, enviados, residentes, } \\
\text { cônsules e outros empregados } \\
\text { franceses no estrangeiro }\end{array}$ & 1790 & 186 & 2 & 7 \\
\hline $\begin{array}{lllll}\text { Cópia } & \text { das } & \text { ordens do governo } \\
\text { Francês em } & \text { Portugal à Junta da } \\
\text { direção } & & & & \\
& & \end{array}$ & $1767-1808$ & 186 & 3 & 1 \\
\hline $\begin{array}{l}\text { Documentos sobre a repressão ao } \\
\text { contrabando na Alfândega no } \\
\text { Porto. Informações, minutas e } \\
\text { anotações de d. Rodrigo em anexo }\end{array}$ & 1781-1806 & 186 & 3 & 2 \\
\hline $\begin{array}{l}\text { Cópia antiga do tratado de paz } \\
\text { entre Portugal e França, com } \\
\text { apontamentos e a declaração de sua } \\
\text { anulação por parte do diretório }\end{array}$ & 1797 & 186 & 3 & 6 \\
\hline $\begin{array}{l}\text { Informações sobre as ilhas de São } \\
\text { Tomé e Príncipe (letra do Conde de } \\
\text { Linhares) }\end{array}$ & $1814-1815$ & 187 & 1 & 7 \\
\hline $\begin{array}{l}\text { Antecedentes do Tratado de } 1797 \\
\text { com a França e Portugal }\end{array}$ & 1795 & 201 & 4 & 2 \\
\hline Tratado de Badajós & 1801 & 201 & 4 & 3 \\
\hline Tratado entre a França e Portugal & 1801 & 201 & 4 & 4 \\
\hline $\begin{array}{l}\text { Quadro estatístico das importações } \\
\text { e exportações entre Portugal e a } \\
\text { Grã-Bretanha }\end{array}$ & $1797-1802$ & 202 & 1 & 1 \\
\hline $\begin{array}{l}\text { História das demarcações da } \\
\text { América entre Portugal e Espanha }\end{array}$ & 1797 & 343 & 2 & 19 \\
\hline
\end{tabular}




\begin{tabular}{|l|l|l|l|l|}
\hline Carta de Antônio de Araújo de & 1797 & 340 & 1 & 5 \\
Azevedo ao senhor Luís Pinto de & & & \\
Sousa Coutinho, enviando \\
documentação ao embaixador de \\
Madrid, 17/09/1797
\end{tabular}

\section{L.- Documentos impressos.}

- Maria Helena Flexor (Org.). Autos de Devassa da Conspiração dos Alfaiates. Salvador: APEB, 2.v., 1998.

- Luís dos Santos Vilhena. Recopilação de Notícias Soteropolitanas e Brasílicas. Salvador: Itapuã, 1969.

- Joaquim Caetano Pereira e Sousa. Esboço de Hum Diccionário Jurídico, Theórico e Practico, Remissivos às Leis Compiladas e Extravagantes, Tomo Segundo, Obra Póstuma, publicada em 1827 pela Typographia Rollandiana.

- Joaquim Caetano Fernandes Pinheiro. A Conspiração de João de Deus, Revista popular, tomo VIII, p 218-221, 1860. BN, sessão de obras raras, PR-SOR-03143[1-8].

- Tratado preliminar de paz e de limites na América Meridional, relativos aos estados, que nella possuem as coroas de Portugal e de Hespanha, Na Régia Officina 
Typografica,

anno

de

1777:

http://www.archive.org/stream/tratadoprelimina00port\#page/6/mode/1up

- Tractado de paz e amizade entre o muito alto e poderoso Senhor Dom João, Principe Regente de Portugal, e o illustrissimo Senhor Jusef Bax Carmanaly, Regente, e Governador de Tripoli, na Régia Officina Typográfica, 1799.

- Tratado de amizade, navigação, e commercio renovado entre Portugal e a Russia, assignado em Petersbourgo ao 16-27 de dezembro de 1798. Na Régia Officina Typográfica, 1800.

- Fr. Antônio de Santa Maria Jaboatão. Novo Orbe Seráfico Brasílico. Recife, Assembleia Legislativa, 1979, 3 t.; José Antônio Caldas. Notícia geral de toda esta capitania da Bahia desde o seu descobrimento até o presente ano de 1759 (1759). Edição facsimilar. Salvador. Tipografia Beneditina Ltda., 1951.

- José Mariano Velloso. Extrato sobre os engenhos de Assucar no Brasil, e sobre o methodo já então praticado na factura deste sal essencial, tirado da obra Riqueza e Opulencia do Brasil, para s combinar com os novos methodos, que agora se propoem debaixo dos auspicios de S. Alteza Real o Príncipe Regente Nosso Senhor. Lisboa: Typographia chalcograpica e litteraria do Arco do Cego, 1800.

- Fernando José de Portugal e Castro. Comentários ao Regimento de Roque da Costa Barreto. In: Marcos Carneiro de Mendonça. Raízes da Formação administrativa do Brasil. Rio de Janeiro: IHGB/CFC, 1972, vol. 2.

- Antônio José de Mello Moraes. “Chronica Geral do Brazil (1700-1800). Rio de Janeiro: B.L.Garnier Editor, 1886, Tomo Segundo.

- Ordenações Filipinas. Livro IV. Lisboa, Fundação Calouste Gulbenkian, s/d, p. 990.

- Thomas Lindley. Narrativa de uma viagem ao Brasil que terminou com o apresamento de um navio britânico e a prisão do autor. São Paulo: Companhia Editora Nacional, 1969. 


\section{Bibliografia}

ABREU, Capistrano de. Capítulos de História Colonial \& Caminhos Antigos e Povoamento do Brasil. Brasília, Editora da UNB, 1963 (1907).

ADAN, Caio Figueiredo Fernandes. Colonial Comarca dos Ilhéus: soberania e territorialidade na América Portuguesa (1763-1808). Dissertação de Mestrado/FFCH/UFBA, 2009.

AIDAR, Bruno. Uma substituição luminosa: tributação e reforma do Antigo Regime português em D. Rodrigo de Souza Coutinho ao final do século XVIII. Nova Economia: Belo Horizonte, 21 (1), pp. 137-156, janeiro-abril de 2011.

AIDAR, Bruno. A tessitura do fisco: a politica ilustrada de D. Rodrigo de Souza Coutinho e a administração fiscal da capitania de São Paulo, 1797-1803. Dissertação de Mestrado/IFCH/UNICAMP, 2007.

ALDEN, Dauril. The Population of Brazil in the Late Eighteenth Century: a preliminar study. HAHR, 43:2, maio de 1963.

ALENCASTRO, Luiz Felipe de. O Trato dos Viventes: Formação do Brasil no Atlântico Sul. Séculos XVI e XVII. São Paulo, Cia das Letras, 2000.

ALEXANDRE, Valentim. Os sentidos do Império: questão nacional e questão colonial na crise do Antigo Regime Português. Porto: Afrontamento, 1993.

AMARAL, Braz do. A Conspiração Republicana de 1798. Rio de Janeiro, Imprensa Nacional, 1927.

ARMITAGE, João. História do Brasil, São Paulo: EDUSP, 1981. A 1ª edição inglesa é de 1836. A primeira edição brasileira é de 1837.

AMBRÓSIO, António. Subsídios para a história de S. Tomé e Príncipe. Livros Horizonte, 1994.

ARAÚJO, Luiz Antônio Silva. Política Pombalina e contratos de tributos régios em Minas Gerais. Anais do XXX Encontro da Associação Portuguesa de História Econômica e Social, cujo sítio foi acessado em 22/10/2011: http://www.iseg.utl.pt/aphes30/fullprog.html

ARRUDA, José Jobson de Andrade. A circulação, as finanças e as flutuações econômicas. In: Nova história da expansão portuguesa, o império luso-brasileiro 17501822. Lisboa:Estampa, 1986. v. VIII.

ARRUDA, José Jobson de Andrade. Decadence or Crisis in the Luso-Brasilian Empire: a new model of colonization in the eighteenth century. Hispanic American Historical Review, 80:4, Duke University Press, 2000. 
ARRUDA, José Jobson de. O Sentido da Colônia. Revisitando a Crise do Antigo Sistema Colonial. In: José Tengarrinha (Org). História de Portugal. São Paulo/ Bauru/Lisboa: EDUNESP/EDUSC/Instituto Camões. 2002.

AZEVEDO, Thales de. Povoamento da Cidade de Salvador. Salvador: Itapuã, 1969.

BANDEIRA, Luiz Alberto Moniz. O Feudo. A Casa da Torre de Garcia d'Ávila: da conquista dos sertões à independência do Brasil. Rio de Janeiro: Editora Civilização Brasileira, 2000.

BAKER, Keith M., ed. The Political Culture of the Old Regime, vol. 1 of The French Revolution and the Creation of Modern Political Culture. Oxford and New York: Pergamon Press, 1987.

BARICKMAN, B.J. Um contraponto baiano: açúcar, fumo, mandioca e escravidão no Recôncavo, 1780-1860. Rio de Janeiro: Civilização Brasileiro, 2003.

BARRETO, António - Invasões francesas: Portugal na fronteira do poder terrestre e do poder marítimo. "Revista Militar", Lisboa, 41 (8) Ago. 1989, p. 565-583.

BARROS, Francisco Borges de. Os Confederados do Partido da Liberdade. Salvador: Imprensa Oficial do Estado, 1922.

BARROS. Francisco Borges de. Primórdios das Sociedades Secretas da Bahia. Salvador, Imprensa Oficial do Estado, 1929.

BARROS, Francisco Borges de. Novos Documentos para a História Colonial. Salvador: Imprensa Oficial do Estado, 1931.

BELlOTTO, Heloísa Liberalli. Vice-Reinado. In: Maria Beatriz Nizza da Silva (Coord). Dicionário da História da Colonização Portuguesa no Brasil. Lisboa: Editorial Verbo, 1994.

BERGÊ, Yvês-Marie. Fête et revolte. Des mentalité populaires Du Xve au XVIII e.siecle. Paris: Hachette, 1994.

BETHENCOURT, Francisco. História das Inquisições, Portugal, Espanha e Itália, Séculos XV-XIX. São Paulo: Cia das Letras, 2000.

BICALHO, Maria Fernanda Baptista. Centro e periferia: pacto e negociação política na administração do Brasil Colonial, Leituras, Biblioteca nacional de Lisboa, 6;17-39, primavera 2000.

BICALHO, Maria Fernanda. As noções de capitalidade no Rio de Janeiro sob a política pombalina. In: Ana Cristina Araújo; José Luís Cardoso et all. O terremoto de 1755: impactos históricos. Lisboa: Livros Horizontes, 2007.

BICALHO, Maria Fernanda. O Rio de Janeiro no século XVIII: a transferência da corte e a construção do território centro-sul da América Portuguesa. Urbana, ano 1, $\mathrm{n}^{\circ} .1$, set/dez, 2006. 
BICALHO, Maria Fernanda Baptista; FERLINI, Vera Lúcia Amaral. Modos de Governar: idéias e práticas políticas no Império Português (séculos XVI a XIX). São Paulo: Alameda, 2005.

BICALHO, Maria Fernanda B (Org.); FURTADO, Júnia Ferreira (Org.); SOUZA, L. M. (Org.). O governo dos povos. 1. ed. São Paulo: Alameda, 2009.

BOXER, Charles Ralph. O Império Colonial Português. Trad. port. São Paulo, Edições $70,1977$.

BOXER, Charles. Conselheiros municipais e irmãos de caridade. In: Maria Beatriz Nizza da Silva. O Império Marítimo português. Trad. Anna Olga de Barros Barreto. São Paulo: Cia das Letras, 2002.

BOXER, Charles. Portuguese Society in the tropics: the municipal councils of Goa, Macao, Bahia, and Luanda, 1510-1800. Madison, The University of Wisconsin Press, 1965.

BRANDÃO, Fernando de Castro. A Política externa portuguesa e a aliança defensiva de 1799 com a Rússia. Heuris, 1985.

BRAUDEL, Fernand. O Mediterrâneo e o mundo mediterrânico na época de Filipe II. 1. ed. Lisboa: Martins Fontes, 1983-1984. 2 v.

BULCÃO SOBRINHO, Antônio de Araújo de Aragão. Famílias Bahianas (Bulcão, Pires de Carvalho e Vicente Viana), vol. 1, Bahia: Imprensa Oficial, 1945.

CALMON, Pedro. História da Casa da Torre: uma dinastia de pioneiros. Rio de Janeiro: Livraria José Olympio, s.d.

CARDOSO, José Luís (coord.), A economia política e os dilemas do Império lusobrasileiro (1790-1822). Lisboa: Comissão Nacional para os Descobrimentos Portugueses, 2001.

CARDOSO, José Luís. O pensamento econômico em Portugal nos fins do século XVIII (1784-1808), Lisboa: Estampa, 1989.

CARDOSO, José Luís. Nas malhas do Império: a economia política e a política colonial de d. Rodrigo de Souza Coutinho. In: José Luís Cardoso (Org.) A economia política e os dilemas do império luso-brasileiro (1790-1822). Lisboa: Comissão Nacional para as Comemorações do Descobrimento Portugueses, 2001.

CARDOSO, José Luís \& CUNHA, Alexandre Mendes. Discurso econômico e política colonial no Império Luso-Brasileiro (1750-1808). Tempo, Rio de Janeiro, Número 31, 2012.

CASALILLA, Bartolomé Yun (dir.). Las redes del Imperio: élites sociales em la articulación de la monarquia hispânica, 1492-1714. Madrid, Marcial Pons, 2009. 
CHARTIER, Roger. Les origines culturelles de la Revolution Française. Paris: Seuil,1990.

CHARTIER, Roger. Leituras e leitores na França do Antigo Regime. São Paulo: Ed. UNESP, 2004.

COELHO, Maria Helena C. e MAGALHÃES, Joaquim Romero. O poder concelhio: das origens às cortes constituintes. Notas da história social. Coimbra, Edição do Centro de Estudos e Formação Autárquica, 1986.

COSTA, André da Silva. Os Secretários e o Estado do Rei: luta de corte e poder político, séculos XVI-XVII. Dissertação de Mestrado, Universidade Nova de Lisboa, 2008.

COSTA, Fernando Dores. Capitalistas e serviços: empréstimos, contratos e mercês no final do século XVIII. Análise Social, vol. XXVII (116-117), $1992\left(2 .^{\circ}-3 .^{\circ}\right)$.

DARNTON, Robert. Edição e sedição: o universo da literatura clandestina no século XVIII. Companhia das Letras: São Paulo, 1992.

DARNTON, Robert. Os dentes falsos de George Washington: um guia não convencional para o século XVIII. São Paulo: Companhia das Letras, 2005.

DAUDIN, Guillaume. Profitability of Slave and Long-Distance Trading in Context: the case of eighteenth-century France. Journal of Economic History, vol. 64, n. 1, March 2004, p. 144-171.

ELLIS, Mirian. O monopólio do sal no estanco do Brasil (1631-1801). Faculdade de Filosofia, Ciências e Letras da Universidade de São Paulo, 1995.

FAORO, Raymundo. Os Donos do Poder: formação do patronato político brasileiro. São Paulo, Ed. Globo-Publifolha, 2000 (1958), vol.1.

FERLINI, Vera Lúcia Amaral. Terra, trabalho e poder. São Paulo, Brasiliense, 1988.

FIGUEIREDO, Luciano. Furores sertanejos na América Portuguesa: rebelião e cultura política no sertão do Rio São Francisco, Minas Gerais, 1736. Revista Oceanos, Lisboa, $\mathrm{n}^{\circ} .40, \mathrm{pp} .128-144,1999$.

FIGUEIREDO, Luciano. O império em apuros: notas para o estudo das alterações ultramarinas e das práticas políticas no império colonial português, séculos XVII e XVIII. In: FURTADO, Júnia Ferreira (Org.). Diálogos Oceânicos: Minas Gerais e as novas abordagens por uma história do Império ultramarino português. Belo Horizonte: Editora da UFMG, 2001.

FIGUEIREDO, Luciano. Protestos, revoltas e fiscalidade no Brasil Colonial. LPH: Revista de História 5, pp. 56-87, 1995.

FIGUEIREDO, Luciano. Revoltas, fiscalidade e identidade na América portuguesa: Rio de Janeiro, Bahia e Minas Gerais, 1640-1761. Tese de Doutorado/FFLCH/USP, 1996. 
FLORY, Rae J. Dell. Bahia society in the mid. Colonial period: the sugar planters, tobacco growers, merchants, and the Recôncavo, 1680-1725. Tese Ph. D., University of Texas atAustin, mimeo.

FOUCAULT, Michel, Microfísica do Poder. 17ed.,Rio de Janeiro, Edições Graal, 2002.

FRAGOSO, João e FLORENTINO, Manolo. O Arcaísmo como Projeto: mercado atlântico, sociedade agrária e elite mercantil no Rio de Janeiro, 1780-1840. Rio de Janeiro, Diadorim, 1993.

FRAGOSO, João, GOUVÊA, Maria de Fátima, e BICALHO, Maria Fernanda. (org.), Antigo Regime Nos Trópicos: a dinâmica imperial portuguesa (séculos XVI-XVIII). Rio de Janeiro, Civilização Brasileira, 2001.

FURTADO, João Pinto. $O$ manto de Penélope: história, mito e memória da Inconfidência Mineira de 1788-9. 1. ed. São Paulo: Companhia das Letras, 2002.

FURTADO, Júnia Ferreira. Homens de negócio: a interiorização da metrópole e do comércio nas minas setecentistas. São Paulo: Hucitec, 1999.

GARCIA, Rodolfo. História Política e Administrativa do Brasil (1500-1810). Rio de Janeiro, José Olímpio, 1956.

GARCIA, Rodolfo. Ensaio sobre a história política e administrativa do Brasil, 15001810. Rio de Janeiro: José Olympio, 1953, $2^{\mathrm{a}}$. edição.

GOUVÊA, Maria de Fátima Silva. Poder, justiça e soberania no império colonial português, Leituras, Biblioteca nacional de Lisboa, 6;97-121, primavera 2000.

GRAMSCI, Antonio. Literatura e vida nacional. Rio de Janeiro: Civilização Brasileira, 1978.

GREENE, JACK. P. Negotiated authorities: essays in colonial political and constitutional history. Charlottesville and London: University Press of Virginia, 1994.

GREENE, Jack P. Peripheries and center : constitutional development in the extended polities of the british empire and the United States, 1607-1788 / Jack P. Greene. New York:W.W. Norton, 1986. XII,274 p.

GUERRA, F. X. El renacer de la historia politica: razones y propuestas. In: ANDRESGALLEGO, J. A. New History, nouvelle histoire, hacia una nueva historia. Madrid, Universidad Complutense de Madrid, 1993.

GUIMARÃES, Carlos Gabriel. O rendimento da Capitania das Minas Gerais no período 1795-1800: uma comparação com as Capitanias do Rio de Janeiro, Bahia e Pernambuco. Disponível no sítio: http://www.cedeplar.ufmg.br/diamantina2004/textos/D04A032.PDF. Acessado em: 24/09/2011. 
HEINZ, Flávio M. Por outra história das elites. Rio de Janeiro: Ed. FGV, 2006.

HENRIQUES, Isabel Castro. São Tomé e Príncipe - A Invenção de uma Sociedade. Lisboa, Vega. 2000.

HESPANHA, Antonio Manoel (org.), Poder e instituições na Europa do Antigo Regime. Lisboa, Fund. Calouste Gulbenkian, 1984.

HESPANHA, Antonio Manoel; XAVIER, Ângela Barreto. As redes clientelares. In: MATTOSO, José (Dir). História de Portugal. Lisboa: Estampa, 1993, vol, 4.

HESPANHA, Antonio Manoel. As Vésperas do Leviathan. Instituições e poder político. Portugal - séc. XVII. Coimbra, Almedina, 1994.

HESPANHA, Antonio Manoel. História das Instituições. Coimbra, Almedina, 1982.

HOBSBAWM, Eric. Bandidos. Rio de Janeiro: Forense-Universitária, 1976.

HOBSBAWM, Eric J. A Era das Revoluções (1789-1848). Rio de Janeiro: Paz \& Terra, 1980.

HUNT, Lynn Avery. Política, cultura e classe na Revolução Francesa. São Paulo: Companhia das Letras, 2007.

IVO, Isnara Pereira. O anjo da morte contra o santo lenho: poder, vingança e cotidiano no sertão da Bahia. Vitória da Conquista: Universidade Estadual do Sudoeste da Bahia, 2004.

JANCSÓ, István. Na Bahia contra o Império: história do ensaio de sedição na Bahia de 1798. São Paulo: Hucitec, 1996.

JANCSÓ, István. A Sedução da liberdade: cotidiano e contestação política no final do século XVIII. In: SOUZA, L. de M. e (Org.). História da vida privada no Brasil, cotidiano e vida privada na América Portuguesa, vol. 1, São Paulo: Companhia das Letras, 1999.

JANCSÓ, István. O 1798 Baiano e a crise do Antigo Regime Português. In: II Centenário da Sedição de 1798 na Bahia. Salvador: Academia de Letras da Bahia, Secretaria da Cultura e Turismo; Brasília: MINC, 1999.

JANCSÓ, István. Bahia 1798: a hipótese do auxílio francês ou a cor dos gatos. in: Furtado, J. F. (Org.) Diálogos Oceânicos: Minas Gerais e as novas abordagens para uma história do Império Ultramarino Português. Belo Horizonte: Ed. UFMG, 2001.

KANTOR, Iris. Usos diplomáticos da ilha-brasil: polêmicas cartográficas $e$ historiográficas. Varia História, v. 37, p. 70-80, 2007.

KANTOR, Iris. Esquecidos \& Renascidos: Historiografia acadêmica luso-americana 
(1724-1759). 1ª . ed. São Paulo: HUCITEC/Centro Estudos Baianos, 2004

KENNEDY, John Norman. Bahian elites, 1750-1822. The Hispanic American Historical Review. Vol. 53, nº. 3. The Duke University Press, 1973.

KISCHNER, Tereza. A administração portuguesa no espaço atlântico: a Mesa da Inspeção da Bahia (1751-1808). In: Biblioteca Digital Camões. Disponível em: http://www.institutocamoes.pt Acessado em 23/03/2007.

KRANTZ, F. (Org.) Ideologia e Protesto Popular nos séculos XVII a XIX. Rio de Janeiro: Jorge Zahar Ed., 1990.

LAMEGO, Alberto. Os motins do Maneta na Bahia. Revista do Instituto Geográfico e Histórico da Bahia. Salvador: Tipografia e Encardenações Empresa Editora, vol. 45, pp. 359-366, 1929.

LARA, Sílvia Hunold. Campos da violência: escravos e senhores na capitania do Rio de Janeiro, 1750 -1808. Rio de Janeiro: Paz e Terra, 1988.

LEVY, Maria Bárbara. História Financeira do Brasil Colonial. Rio de janeiro: IBMEC, 1979.

LUGAR, Catherine. The merchant community of Salvador, Bahia, 1780-1830. Ann Arbor: [s.n.], 1980.

LYRA, Maria de Lourdes Viana. A utopia do poderoso Império. Portugal e Brasil: bastidores da política (1798- 1822). Rio de Janeiro: Sette Letras, 1994.

MAGALHÃES, Joaquim Romero de. "Os Concelhos", in: MATTOSO, José (org). História de Portugal. Lisboa, Editora Estampa, 1993, vol. 3.

MAGALHÃES, Joaquim Romero de. Reflexões sobre a estrutura municipal portuguesa e a sociedade colonial portuguesa, Revista de História Econômica e Social, 16, 1986.

MAGALHÃES, Joaquim Romero de. O Algarve econômico, 1600-1773. Lisboa: Estampa, 1993.

MAGALHÃES, José Calvet de - História das relações diplomáticas entre Portugal e os Estados Unidos da América: 1776-1911. Lisboa, Europa América, 1990.

MARQUES, Viriato Soromenho - Um texto inédito de Kant: o valor estratégico de Portugal no final do século XVIII. "História", Lisboa, 12 (125) Fev. 1990, p. 12-17.

MASCARENHAS, Maria José Rapassi. Fortunas Coloniais: Elite e Riqueza em Salvador (1760 - 1808). São Paulo: USP/Tese de Doutoramento, 1998.

MAURO, Frédéric. O papel econômico do fiscalismo no Brasil colonial (1500-1800). In: MAURO, Frédéric. Nova História e novo mundo. São Paulo: Perspectiva/Edusp, 1969. 
MATTOSO, Kátia M. de Queirós. Da Revolução dos Alfaiates à riqueza dos baianos no século XIX. Salvador: Corrupio, 2004.

MATTOSO, Kátia M. de Queirós. Bahia, século XIX: uma província no Império. Rio de Janeiro, Nova Fronteira, 1992.

MATTOSO, Kátia M. de Queirós. Presença francesa no Movimento Democrático Baiano de 1798. Salvador: Itapuã, 1969.

MAXWELL, Kenneth. A Devassa da devassa - Inconfidência Mineira: Brasil e Portugal (1750-1808). São Paulo: Paz e Terra, 1977.

MAXWELL, Kenneth. A Devassa da devassa - Inconfidência Mineira: Brasil e Portugal (1750-1808). São Paulo: Paz e Terra, 1977.

MAXWELL, Kenneth. A geração de 1790 e a ideia do império luso-brasileiro. In: MAXWELL, Kenneth. Chocolate, piratas e outros ensaios tropicais. Rio de Janeiro: Paz e Terra, 1999.

MELLO, Evaldo Cabral de. A fronda dos mazombos: nobres contra mascates. Pernambuco 1666-1715. São Paulo: Cia. das Letras, 1995.

MENDES, Claudinei Magno Magre. Crédito e Usura na época Colonial: Autores Coloniais e Historiografia. Mirandum 18, Universidade do Porto, 2007, pp. 31-48.

MENDONÇA, Marcos Carneiro de. Raízes da formação administrativa do Brasil, Rio de Janeiro, Instituto Histórico e Geográfico Brasileiro/Conselho Federal de Cultura, 1972.

MIRANDA, Tiago C. P. dos Reis. Ceder Timor Leste. REVISTA USP, São Paulo, n.79, p. 82-93, setembro/novembro, 2008.

MONTEIRO, Nuno Gonçalo. Os concelhos e as comunidades, in: MATTOSO, José (org). História de Portugal. Lisboa, Editora Estampa, 1993, vol. 4.

MONTEIRO, Nuno Gonçalo. Elites e Poder. Entre o Antigo Regime e o Liberalismo. Lisboa, Imprensa de Ciências Sociais, 2003.

MONTEIRO, Nuno Gonçalo. $O$ 'Ethos' Nobiliárquico no final do Antigo Regime: poder simbólico, império e imaginário social. Almanack Braziliense. São Paulo, n.2, novembro de 2005.

MONTEIRO, Nuno Gonçalo. Poder senhorial, estatuto nobiliárquico e aristocracia. In: HESPANHA, Antônio Manuel (org.). História de Portugal: o Antigo Regime. Lisboa: Editorial Estampa, 1998.

MONTEIRO, Nuno Gonçalo. Notas sobre nobreza, fidalguia e titulares nos finais do Antigo Regime. Ler História, n.10, pp.15-51, 1987.

MOTA, Carlos Guilherme. Ideia de Revolução no Brasil. São Paulo: Cortez, 1986. 
MOTTA, Márcia Maria Mendes. Morgadios e capelas na América Portuguesa do século XVIII. Disponível em: web.letras.up.pt/aphes29/data/4th/MarciaMotta_Texto.pdf. Acessado em 30/08/2012.

NASCIMENTO, Ana Amélia Vieira. Patriarcado e religião: as enclausuradas clarissas do Convento do Desterro da Bahia, 1677-1890. Lisboa: Conselho de Cultura, 1994.

NARDI, Jean Baptiste. O fumo brasileiro no período colonial: lavoura, comércio e administração. São Paulo: Brasiliense, 1996.

NEVES, Carlos Filomeno Azevedo Agostinho das. S. Tomé e Príncipe na $2^{a}$ metade do século XVIII. Lisboa: CHAM, 1988.

NOVAIS, Fernando A.. Portugal e o Brasil na Crise do Antigo Sistema Colonial (17771808). 2a . ed.,São Paulo, Hucitec, 1981 (1972).

NOVAIS, Fernando Antônio. Aproximações: estudos de história e de historiografia. São Paulo: Cosac\&Naïf, 2005.

OLIVAL, Fernanda. Rigor e interesses: os estatutos de limpeza de sangue em Portugal. Cadernos de Estudos Sefarditas, n.4, p.151-182.

OLIVEIRA, Aurélio de Araújo. Contribuição para o estudo das revoltas e motins populares em Portugal durante a época moderna: as sublevações de Viana do Castelo em 1636. Porto [s.l.], 1979, mimeografado.

OLIVEIRA FILHO, Roque Felipe de. Crimes e perdões na ordem jurídica colonial, Bahia, 1750-1808. Tese de Doutorado, Universidade Federal da Bahia, 2009.

PADGEN, Nichols Canny and Anthony. Colonial identity in the Atlantic world: 15001800. Princeton, N.J: Princeton Univ, 1989.

PEDREIRA, Jorge. Estrutura industrial e mercado colonial. Portugal e Brasil, 17801830. Lisboa: Estampa, 1994.

PEDREIRA, Jorge. Os homens de negócio da praça de Lisboa de Pombal ao vintismo (1755-1822): diferenciação, reprodução e identificação de um grupo social. Tese de Doutorado, Universidade Nova de Lisboa, 1995.

PEDREIRA, Jorge; COSTA, Fernando Dores. D. João VI. Lisboa: Círculo de Leitores, 2009.

PEDREIRA, Jorge Miguel. Tratos e contratos: actividades, interesses e orientações dos investimentos dos negociantes da praça de Lisboa (1755-1822. Análise Social,, vol. XXXI (136-137), $1996\left(2 .^{\circ}-3 .^{\circ}\right)$.

PINJING, Ernst. Contrabando, ilegalidade e medidas políticas no Rio de Janeiro do século XVIII. Revista Brasileira de História. São Paulo, v. 21, n42, 2001, pp. 397-414. 
PINTASSILGO, Joaquim. Diplomacia Política e Econômica na transição do século XVIII para o século XIX: o pensamento e a acção de Antônio de Araújo de Azevedo (Conde da Barca). Dissertação de Mestrado em História apresentada à Faculdade de Ciências Sociais e Humanas da Universidade Nova de Lisboa, Lisboa, 1987.

POTELET, Jeanine. Projets d'expéditions et d'attaques sur les côtes du Brésil (17961800). In: L'Amérique Latine face a La Révolution Française, Toulouse: Caravelle, Cahiers du Monde Hispanique et Luso-Bresilien, $\mathrm{n}^{\circ}$ 54, 1990.

PRADO JÚNIOR, Caio. Formação do Brasil Contemporâneo. São Paulo, Ed. GloboPublifolha, 2000 (1942).

PUNTONI, Pedro. Bernardo Vieira Ravasco, secretário do Estado do Brasil: poder e elites na Bahia do século XVII. In: Modos de Governar: idéias e práticas políticas no Império Português, séculos XVI-XIX. São Paulo: Alameda, 2005.

REIS, Arthur Cézar Ferreira. A ocupação de Caiena. In: Sérgio Buarque de Holanda (Dir.). História Geral da Civilização Brasileira: o Brasil Monárquico. São Paulo: Difel, 1976, Tomo II, Vol. I, pp. 278-299.

REMOND, René (org.). Por uma história política. Rio de Janeiro, Ed. UFRJ/ Ed. FGV, 1996.

REVEL, Jacques. Jogos de escalas. A experiência da microanálise. Rio de Janeiro, Fundação Getúlio Vargas, 1998.

RIBEIRO, Alexandre Vieira. A cidade de Salvador: estrutura econômica, comércio de escravos, grupo mercantil (c.1750 - c.1800). Tese de Doutoramento. Rio de Janeiro, DH/IFCS/UFRJ, 2009.

RIBEIRO, E. M. S. Abastecimento de farinha da cidade do Salvador: aspectos históricos. Dissertação (Mestrado), Faculdade de Filosofia e Ciências Humanas, Universidade Federal da Bahia, Salvador, 1982.

RODRIGUES, Aldair Carlos. Sociedade e Inquisição em Minas colonial: os familiares do Santo Ofício (1711-1808). Dissertação de Mestrado, DH/FFLCH/USP, 2007.

ROMEIRO, Adriana. Paulistas e Emboabas no coração das Minas: ideias, práticas e imaginário político no século XVIII. Belo Horizonte: Editora UFMG, 2008.

RUSSEL-WOOD, Anthony John R. A dinâmica da presença brasileira no Índico e no Oriente. Séculos XVI-XIX. Topoi, Rio de Janeiro, set. 2001.

RUSSEL-WOOD, A.J., Um Mundo em Movimento: Os Portugueses na África, Ásia e América,1415/1808. Lisboa, DIFEL, 1998.

RUSSEL-WOOD, A.J. Fidalgos e filantropos. Santa Casa da Misericórdia da Bahia,1550-1775. Brasília: EdUNB, 1981. 
RUSSEL-WOOD, A.J. O governo local na América Portuguesa: um estudo de divergência cultural. Revista de História, São Paulo, v. 55, nº. 109, jan/mar, 1977.

RUSSEL-WOOD, A.J. Centro e periferia no mundo luso-brasileiro, Revista Brasileira de História, v. 18, nº. 36, pp. 187-249, 1998.

RUSSEL-WOOD, A.J. From colony to nation: essays on the independence of Brazil. The Johns Hopkins University Press, 1975.

SALGADO, Graça (coord.). Fiscais e meirinhos. Administração no Brasil colonial. Rio de Janeiro: Nova Fronteira; Brasília: INL, 1985.

SAMPAIO, Antônio Carlos Jucá de. Crédito e Circulação Monetária na Colônia: o caso Fluminense, 1650-1750. V Congresso Brasileiro de História Econômica, Caxambu: ABPHE, 2003.

SANTOS, Catarina Madeira. Goa é a chave de toda a Índia: Perfil Político da Capital do Estado da Índia (1505-1570), Lisboa: CNCDP, 1999.

SANTOS, Marilia Nogueira dos. Escrevendo cartas, governando o império. A correspondência de Antônio Luís Gonçalves da Câmara Coutinho no governo do Estado do Brasil. Niterói: Programa de Pós-Graduação em História da Universidade Federal Fluminense, 2007. Dissertação de Mestrado.

SANTOS, Milton. A rede urbana do Recôncavo. In BRANDÃO, Maria (org.), Recôncavo da Bahia: sociedade e economia em transição. Salvador: Fundação Casa de Jorge Amado; Academia de Letras da Bahia; Universidade Federal da Bahia, 2008.

SANTOS, Nívia Pombo Cisne dos Santos. D. Rodrigo de Sousa Coutinho e a geração de 1790. Anais do X Encontro Regional de História, Rio de Janeiro, 2002.

SARAIVA, José Hermano. Evolução histórica dos municípios portugueses. Lisboa: Editora do Centro de Estudos Políticos Sociais, 1957.

SARTRE, Jean Paul. Questão de método. São Paulo: Nova Cultural, 1987.

SEIBERT, Gerhard. Náufragos, autóctones ou cimarrones? O debate sobre a Origem dos Angolares de São Tomé. Centro Cultural Português, Instituto Camões, São Tomé e Príncipe. 2005.

SCHWARTZ, Stuart, Burocracia e Sociedade no Brasil Colonial. A Suprema Corte da Bahia e seus juízes (1609-1751). São Paulo, Perspectiva, 1979.

SCHWARTZ, Stuart. Segredos Internos: engenhos e escravos na sociedade colonial 1550-1835. São Paulo, Cia das Letras, 1999.

SKINNER, Quentin. As fundações do pensamento político moderno. São Paulo, Companhia das Letras. 1996.

SIMÕES FILHO, Afrânio Mário. Política de abastecimento na economia mercantil: $o$ 
celeiro público da Bahia (1785-1866). Tese de Doutorado, FFCH/UFBA, 2011.

SILVA, Alberto da Costa e. Francisco Félix de Sousa, mercador de escravos. Rio de Janeiro: Nova Fronteira: Eduerj, 2000.

SILVA, Alberto da Costa e. Um rio chamado atlântico: a África no Brasil e o Brasil na África. Rio de Janeiro: Nova Fronteira; UFRJ, 2003.

SILVA, Ana Rosa Cloclet. Minas no contexto da "acomodação": as relações de poder, as práticas políticas e as tessituras das identidades. Revista Aulas: Dossiê Identidades Nacionais, n. 2, 2006.

SILVA, Andrée Mansuy Diniz. Portrait d'um homme d'État: d. Rodrigo de Souza Coutinho, Comte de Linhares (1755-1812). Paris: Centre Culturel Calouste Gulbenkian, 2006.

SILVA, Daniel Domingues da. Aspectos comparativos do tráfico de africanos para o Brasil (séculos XVIII e XIX). Revista Afro-Ásia, n 31, 83-126, 2004.

SILVA, Andrée Diniz-Mansuy. Portrait d'un Homme d'État: D. Rodrigo de Souza Coutinho, Comte de Linhares, 1755-1812, vol. II. Paris: Centre Culturel Calouste Gulbenkian, 2006.

SILVA, Inácio Accioli de Cerqueira e, Memórias Históricas e Políticas da Bahia, anotadas por Braz do Amaral, 6 vols. Bahia: Imprensa Oficial, 1919-1940.

SILVA, Inácio Accioli de Cerqueira e. Memórias Históricas e Políticas da Província da Bahia. Bahia: Typ. Do Correio Mercantil, de Précourt, 1835, Tomo I.

SILVA, Júlio Joaquim da Costa Rodrigues da. Ideário Político de uma elite de Estado (1777-1793). Lisboa: Fundação Calouste Gulbenkian, 2002.

SILVA, Kalina Vanderlei Paiva da. Nas solidões vastas e assustadoras: os pobres do açúcar e a conquista do sertão de Pernambuco nos séculos XVII e XVIII. Tese de Doutoramento, UFPE, Recife, 2003.

SILVA, Maria Beatriz Nizza da. Ser nobre na colônia. São Paulo: Editora UNESP, 2005.

SILVA, Rogério. F. da. Colônia e Nativismo: a história como biografia da Nação. São Paulo: Hucitec, 1997.

SILVEIRA, Marco Antônio. O Universo do Indistinto. Estado e Sociedade nas Minas Setecentistas (1735-1808). São Paulo: Editora Hucitec, 1997.

SILVEIRA, Marco Antônio. Guerra de usurpação, guerra de guerrilhas: conquista e soberania nas Minas setecentistas. Varia História, Belo Horizonte, $\mathrm{n}^{\circ}$. 25, julho, 2001. SOBOUL, Albert. A Revolução Francesa. Rio de Janeiro: Difel, 2007, 9ª Edição. 
SOEIRO, Susan. The Social and the Economic Role of the convent: woman and nuns in colonial Brasil, 1677-1800. HAHR, may, 1974, v. 54, nº 1.

SOUSA, Avanete Pereira. Poder local, cidade e atividades econômicas, Bahia, século XVIII. Tese de Doutorado, FFLCH/USP, 2003.

SOUZA, Laura de Mello e. Cláudio Manuel da Costa. São Paulo: Companhia das Letras, 2011.

SOUZA, Laura de Mello e. O Sol e a Sombra: política e administração na América portuguesa do século XVIII. São Paulo: Companhia das Letras, 2006.

SOUZA, Laura de Mello e. Norma e conflito: aspectos da história de Minas no século XVIII. Belo Horizonte: Editora da UFMG, 1999.

SUBRAHMANIAM, S. Connected Histories: Notes Towards a Reconfiguration of Early Modern Eurasia. Modern Asian Studies, vol. 31, nº 3, pp. 735-762.

TAVARES, Luís Henrique Dias. História da Bahia. São Paulo: Editora da Unesp, 2001.

TAVARES, Luís Henrique Dias. História da Sedição intentada na Bahia em 1798 (A Conspiração dos Alfaiates). São Paulo/Brasília: Pioneira/INL, 1975.

TAVARES, Luís Henrique Dias. Da sedição de 1798 à Revolta de 1824 na Bahia. São Paulo/Bahia: Editora da Unesp/EDFBA, 2003.

THOMPSON, E. P. Costumes em comum. São Paulo: Companhia das Letras, 1998.

VASCONCELOS, Pedro de A. Salvador: Transformações e Permanências (1549 1990). In: Berta. K. Becker et alli. (Orgs). Geografia e Meio Ambiente no Brasil. São Paulo. São Paulo: Hucitec, 1995.

VALIM, Patrícia. O preço da Liberdade. Revista de História da Biblioteca Nacional. Ano 1, no 10, maio-julho/2006, pp. 68-71.

VALIM, Patrícia. O tempo em que todos seremos iguais. Revista História Viva, Ano V, $\mathrm{n}^{\circ} .49$, novembro, 2007, pp. 88-92.

VALIM, Patrícia. Da Sedição dos mulatos à Conjuração Baiana de 1798: a construção de uma memória histórica. Dissertação de Mestrado, DH/FFLCH/USP, 2007.

VARNHAGEN, Francisco Adolfo. História geral do Brasil antes de sua separação e independência de Portugal. Belo Horizonte/São Paulo: Itatiaia/Edusp, 10a. edição integral. 1981.

VESENTINI, Carlos Alberto. A teia do fato: uma proposta de estudo sobre a memória histórica. São Paulo: Hucitec, 1997. 
VIANA, José Francisco de Oliveira. Evolução do povo brasileiro. Rio de Janeiro: José Olympio, 1957.

VILHENA, Luís dos Santos. Recopilação de notícias soteropolitanas e brasílicas. Salvador: Itapuã, 1969.

VILLALTA, Luiz Carlos. Reformismo Ilustrado, censura e práticas de leitura: usos do livro na América Portuguesa. Tese de Doutorado/FFLCH/USP, 1999.

VILLALTA, Luís Carlos. Liberdades imaginárias. In: Adauto Novaes (Org.). O Avesso da Liberdade. São Paulo: Companhia das Letras, 2002.

XAVIER, Ângela Barreto; e HESPANHA, António Manoel. "As Redes Clientelares", in: MATTOSO, José (org). História de Portugal. Lisboa, Editora Estampa, 1993, vol. 4.

WADSWORTH, James E. Joaquim Marques de Araújo: o poder da Inquisição em Pernambuco no fim do período colonial. In: Maria Beatriz Nizza da Silva. (Org) De Cabral a Pedro I: Aspectos da colonização portuguesa no Brasil. Porto: Humberpto, 2001.

WALLERSTEIN, Immanuel. O sistema mundial moderno. Porto: Afrontamento, 1974, 2 vols.

WEBER, Max. Economia e Sociedade: fundamentos da sociologia compreensiva. Brasília: Editora da UNB, 1999, 2 vols.

WEHLING, Arno; WEHLING, Maria José. Direito e Justiça no Brasil Colonial - O Tribunal da Relação do Rio de Janeiro (1751- 1808). - Rio de Janeiro: Renovar, 2004. 